\title{
Desamparo psíquico nos filhos de dekasseguis no retorno ao Brasil
}

\author{
Cizina Célia Fernandes Pereira Resstel
}

RESSTEL, CCFP. Desamparo psíquico nos filhos de dekasseguis no retorno ao Brasil [online]. São Paulo: Editora UNESP; São Paulo: Cultura Acadêmica, 2015, 300 p. ISBN 978-85-7983-674-9.

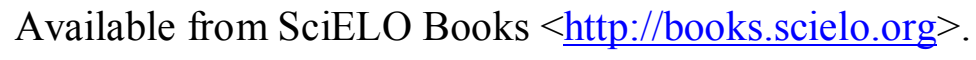

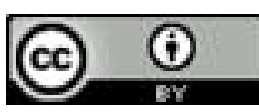

All the contents of this work, except where otherwise noted, is licensed under a Creative Commons Attribution 4.0 International license.

Todo o conteúdo deste trabalho, exceto quando houver ressalva, é publicado sob a licença Creative Commons Atribição 4.0.

Todo el contenido de esta obra, excepto donde se indique lo contrario, está bajo licencia de la licencia Creative Commons Reconocimento 4.0. 


\section{DESAMPARO PSÍQUICO NOS FILHOS DE DEKASSEGUIS NO RETORNO AO BRASIL}


Conselho Editorial Acadêmico

Responsável pela publicação desta obra

José Sterza Justo (Coordenador do Programa)

Silvio Yasui (Membro do Conselho)

Leonardo Lemos de Souza (Vice-Coordenador do Programa) 


\section{CIZINA CÉLIA FERNANDES PEREIRA RESSTEL}

\section{Desamparo PSÍQuico NOS FILHOS DE DEKASSEGUIS NO RETORNO AO BRASIL}

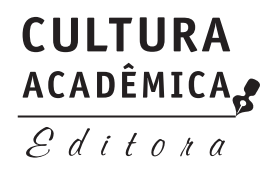


(C) 2015 Cultura Acadêmica

\section{Cultura Acadêmica}

Praça da Sé, 108

01001-900 - São Paulo - SP

Tel.: (0xx11) 3242-7171

Fax: (0xx11) 3242-7172

www.culturaacademica.com.br

www.livrariaunesp.com.br

feu@editora.unesp.br

CIP - Brasil. Catalogação na publicação

Sindicato Nacional dos Editores de Livros, RJ

\section{R343d}

Resstel, Cizina Célia Fernandes Pereira

Desamparo psíquico nos filhos de dekasseguis no retorno ao Brasil [recurso eletrônico] / Cizina Célia Fernandes Pereira Resstel. - 1.ed. São Paulo: Cultura Acadêmica, 2015.

Recurso digital

Formato: epub

Requisitos do sistema: Adobe Digital Editions

Modo de acesso: World Wide Web

ISBN 978-85-7983-674-9 (recurso eletrônico)

1. Brasileiros de origem japonesa - História. 2. Imigrantes - Japão Estatísticas. 3. Trabalhadores brasileiros estrangeiros - Japão. 4. Livros eletrônicos. I. Título.

15-27117

CDD: 305.8698052

CDU: $314.742(52)$

Este livro é publicado pelo Programa de Publicações Digitais da Pró-Reitoria de Pós-Graduação da Universidade Estadual Paulista "Júlio de Mesquita Filho" (Unesp)

Editora afiliada:

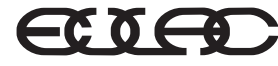

Asociación de Editoriales Universitarias de América Latina y el Caribe

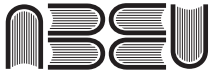

Associação Brasileira de Editoras Universitárias 
Ao meu querido esposo, Fábio Resstel 



\section{Agradecimentos}

Primeiramente, agradeço ao Plano Superior, pelas ideias.

Aos meus pais, José Fernandes Pereira e Tercília Marani Fernandes Pereira, pessoas simples que não mediram esforços para me dar uma formação superior.

Agradeço, em especial, ao meu esposo, Fábio Resstel, companheiro inseparável, pessoa admirável por sua cumplicidade incondicional, que contribuiu para que pudesse dar sequência aos meus estudos no Brasil, apoiando-me em todos os momentos difíceis para a realização dos meus objetivos.

À minha querida irmã, Ana Paula Fernandes Pereira, pessoa admirável e figura singular e especial em minha vida.

Ao meu irmão, José Junior, que é migrante em terras brasileiras, pelo seu afeto.

À minha cunhada Rosemeyre e às minhas queridas sobrinhas Fernanda, Flávia e Acza, pelo apoio.

Ao meu avô, Lázaro Marani, que aos 96 anos de idade é um exemplo de força e vida.

Aos meus saudosos avós, Cizino Fernandes Pereira e Maria Rosa Pereira, que caminham juntos em minhas lembranças. 
Às amigas que fui encontrando ao longo da vida, Selminha Ishi, Andréa Yonamine, Daniela (psicóloga), Cleuza (do Japão) e Rosa Tamashiro.

Às professoras e psicólogas Deíse Gouvêa e Dra. Marília Higa, pelo afeto e apoio.

À minha amiga Adriana Aparecida Almeida de Oliveira; mais do que companheira de grupo do mestrado, sempre esteve atuante em minha nova formação.

Ao grupo de orientação de mestrado, ao Alexandre, à Cledione e ao Felizardo, pela colaboração.

Às amigas de mestrado, Juliana Araújo, Tânya, Fabiana Ribeiro e Bárbara, pela amizade e apoio.

Às companheiras de psicologia clínica Heloísa Boechat, Édna Cardoso, à supervisora e psicanalista Regina Colucci e à minha psicoterapeuta Márcia Guedes, pelo carinho.

À professora e Dra. Mary Y. Okamoto, por ter me convidado para participar do projeto da JICA em parceria com a Unesp/Assis (2012).

Ao professor Dr. Francisco Hashimoto, pela sua sensibilidade e afetividade ao me acolher e amparar na Unesp de Assis.

Ao meu orientador, professor livre-docente Dr. José Sterza Justo, por ter me orientado neste trabalho, acompanhando-me em momentos difíceis e aliviando-me de minhas angústias, ensinando e me apoiando a todo instante.

Ao Nikkei Clube de Marília, que abriu as portas da instituição para que eu pudesse realizar a pesquisa.

Ao senhor Miyazato, do Nikkei Clube de Marília, pelo seu apoio.

Aos dekasseguis, pela presença marcante na transformação histórica da imigração japonesa.

Ao professor Renan Camargo, que contribuiu com as revisões de textos e as traduções do inglês e espanhol.

Aos funcionários da seção de Pós-Graduação da Faculdade de Letras de Assis (Unesp), pelo acolhimento e apoio. 
Ao Programa de Pós-Graduação em Psicologia e Coordenação de Aperfeiçoamento de Pessoal de Nível Superior (CAPES), pelo financiamento e auxílio no desenvolvimento da pesquisa.

Aos amigos e familiares, pelo carinho e auxílio.

Enfim, agradeço a todos os participantes da pesquisa, pela paciência e colaboração. 



\section{Encontros e Despedidas}

Mande notícias do mundo de lá Diz quem fica

Me dê um abraço,

Venha me apertar

Tô chegando

Coisa que gosto

É poder partir

Sem ter plano

Melhor ainda

É poder voltar

Quando quero

Todos os dias

É um vai e vem

A vida se repete

$\mathrm{Na}$ estação

Tem gente que chega

Pra ficar

Tem gente que vai

Pra nunca mais

Tem gente que vem 
E quer voltar

Tem gente que vai

E quer ficar

Tem gente que veio

Só olhar

Tem gente a sorrir

E a chorar

E assim, chegar

E partir

São só dois lados da mesma viagem

O trem que chega

É o mesmo trem da partida

A hora do encontro

É também despedida

A plataforma desta estação

É a vida desse meu lugar

É a vida desse meu lugar

É a vida

(Milton Nascimento e Fernando Brant, 1985) 


\section{SUMÁRIO}

Prefácio 15

Prólogo 21

Introdução 29

1. Fenômeno migratório 35

2. Transnacionalismo 53

3. A experiência da separação para os imigrantes 79

4. Desamparo psíquico 87

5. Conhecendo a família:

pais dekasseguis e filhos imigrantes 105

6. Mundo de lá e mundo de cá:

os dois lados da experiência do imigrante e seus desafios 115

Considerações finais 253

Referências bibliográficas 293

Glossário 299 



\section{Prefácio}

O fenômeno migratório acentuou-se consideravelmente ao longo da história da humanidade. Desde suas origens, o deslocamento de um lugar a outro e o alcance de plagas cada vez mais longínquas foram uma das experiências mais importantes que permitiram que o homem conseguisse se constituir como tal e se fortalecer na terra. Recentemente, a mobilidade e os deslocamentos se intensificaram ainda mais com as facilidades dos meios de transporte e de comunicação. As velhas e bastante conhecidas imigração e emigração - o deslocamento de contingentes populacionais de um país a outro, de um continente a outro - hoje assumem feições ainda mais radicais, acentuando a experiência trans nos planos psicológico, cultural, social e geográfico. Diferentemente de outros tempos, as imigrações hoje são mais difusas, transgressoras, maleáveis e flexíveis, transpondo as fronteiras nacionais num verdadeiro vaivém constante, seja dos próprios imigrantes, seja daquilo que veiculam de um país a outro, mediante ações materiais ou imateriais capazes de gerar efeitos multilaterais entre países distantes. Efeitos esses, é necessário reiterar, que ocorrem nos planos econômico, cultural, social e subjetivo.

Vivemos num mundo trans, a saber, de trânsito, de conexões; um mundo interligado por redes por onde circulam, em direções várias, mercadorias, trabalho, capital, informações, conhecimentos, 
cultura, sentimentos, afetos e tudo o mais que o homem é capaz de criar e produzir. Os imigrantes são parte importante dessa rede e se movimentam de tal forma por ela que já não faz muito sentido diferenciar, como antes, as migrações (referidas a deslocamentos regionais dentro de um país) das emigrações (deslocamentos de nacionais para outros países) e das imigrações (vinda de estrangeiros para um determinado país). Também não faz muito sentido diferenciar os países emissores dos países receptores de emigrantes/ imigrantes. O Brasil, por exemplo, é um país emissor e ao mesmo tempo receptor dentro dessa ampla maleabilidade do fenômeno migratório, além de, ocasionalmente, receber levas de brasileiros emigrados que retornam, como aconteceu na crise econômica de 2008. No entanto, as reversões de correntes de fluxos migratórios não ocorrem somente nas ocasiões de crise econômica que afetam um ou outro país. A chamada imigração de retorno, embora não tão visível, ocorre frequentemente na experiência comezinha do imigrante, sendo um forte componente da sua subjetividade que, se não o faz voltar, o faz, pelo menos, sonhar com o retorno.

Enfim, trata-se de um fenômeno bastante complexo que, pela sua volatilidade e pelo seu caráter supranacional, pode ser entendido e tratado simplesmente como migração. Porém, diferentemente da migração das aves, que vão e voltam sempre fazendo uma mesma rota entre duas regiões, a migração humana atual não possui direções e alvos fixos, e tampouco possui durabilidade ou desenvolve enraizamentos. Como no caso daqueles imigrantes que vão e voltam e não se sentem mais adaptados a um ou outro lugar, a imigração se inscreve hoje na tendência atual de produção de desenraizamentos e de flexibilização de vínculos.

É preciso também ter ciência de que as migrações atuais são deveras heterogêneas. Seus motivos e sentidos são bastante diversos, tanto no plano individual quanto no plano coletivo de agrupamentos e identidades que se formam nesse tipo de experiência. Em alguns casos, pesam mais razões econômicas e os sonhos de enriquecimento; porém, em outros, é o desejo de aventura, de conhecer outros mundos, de expandir as experiências pessoais, de fugir de agruras 
e pesares, de livrar-se de opressões próximas e locais, e assim por diante. Da mesma forma, são diversos os ganhos, as realizações, as conquistas, os sucessos ou os desafios, problemas, frustrações e sofrimentos vividos na experiência migratória.

Muitos emigram sozinhos, ainda jovens; outros decidem emigrar em idade mais avançada; e há os casos de famílias inteiras que emigram (avós, pais e filhos), dentre tantas outras situações. Outra diferença importante diz respeito à migração realizada dentro da oficialidade, dentro das leis existentes e que regulam os fluxos migratórios, e àquela migração insurgente, feita à revelia das leis e que configura os casos dos assim chamados "imigrantes não documentados".

O fenômeno migratório, hoje, comporta toda essa diversidade de situações, experiências e sentidos, tornando-o um fenômeno deveras complexo. No entanto, enquanto expressão das condições de mobilidade, da hipercinética e da dromologia que grassa o mundo contemporâneo, a imigração carrega consigo essa força comum - a força cinética - que afeta a todos; e não somente a todos os imigrantes, mas também àqueles que não migram no sentido tradicional, isto é, aqueles que permanecem no seu país, em territórios estáveis e bem delimitados, porém realizam percursos curtos e micromovimentações no cotidiano: "migram" de um trabalho a outro, de um relacionamento afetivo ou conjugal a outro, de uma profissão a outra; transitam entre valores morais, entre identidades ou núcleos identitários, entre mercadorias, gostos e estilos fomentados pelo modismo, e assim por diante. De certa forma, podemos dizer que a subjetividade promovida e incitada na atualidade é do tipo nômade, migrante, rizomática, mutante, dispersiva e fractal.

Portanto, estudar e procurar conhecer as migrações atuais é buscar compreender também o funcionamento do nosso mundo, do nosso tempo. A experiência do migrante diz, e muito, da experiência de cada um enquanto Homo viator, esse homem viajante, ambulante ou errante, ainda que suas viagens e deambulações se façam pelos sonhos, devaneios ou pela internet e redes sociais.

Este livro, ao focalizar experiências de dekasseguis, retrata, antes de tudo, esse mundo de experiências extremas de mobilidade, capaz 
de interligar pessoas e países situados em territórios distantes. Os dekasseguis, efetivamente, representam o transnacionalismo, a transculturalidade e a transubjetividade mais radical, ou seja, suas ações são capazes de reverberar nos planos econômico, social, político, cultural e subjetivo de povos e países situados em extremos do planeta. Num aspecto, incontestavelmente, os dekasseguis, mais do que outros emigrantes brasileiros, retratam fielmente o vaivém do mundo atual ou a intensa mobilidade: se deslocam com bastante frequência entre o Brasil e o Japão. Muitos dekasseguis já estiveram em longas temporadas de trabalho no Japão mais de uma vez; outros vão e voltam periodicamente, configurando uma situação de residência ou de permanência temporária nesses dois países. Nessas idas e vindas acontecem as mais variadas situações: um membro da família emigra, depois vão os demais; passado algum tempo, retornam juntos ou separadamente, em momentos diferentes; alguns não retornam, se fixam no Japão sozinhos ou com familiares; outros vão casados e voltam solteiros, ou vice-versa, e assim por diante.

Dentre todas as situações, uma tem chamado bastante a atenção e é o foco deste livro: a das crianças que acompanham seus pais. Em outros tempos, a criança não era objeto de interesse e preocupação da ciência ou da sociedade como um todo, sendo praticamente desconsiderada na história da imigração. Nos movimentos migratórios para a América, do final do século XIX e início do século XX, havia pouca sensibilidade para com as experiências das crianças, e nenhuma atenção era dispensada a elas. Apenas acompanhavam seus pais e se submetiam às decisões deles. Atualmente, com a ampliação do reconhecimento da criança e do adolescente como atores sociais importantes e sujeitos de direitos, começam a surgir preocupações específicas com eles entre os próprios imigrantes adultos, assim como na ciência e nas políticas públicas voltadas para a imigração.

Este livro é parte dessa guinada, relativamente recente, dos estudos migratórios, e da psicologia em particular, na direção de focalizar as crianças e adolescentes que vivem a imigração na companhia de seus pais ou familiares. Se para aos adultos a imigração é uma experiência desafiadora e até temerária, para as crianças e adolescentes 
não é menos difícil, ainda que sob a proteção e tutela dos pais. Também no caso das crianças e adolescentes, as experiências são díspares até porque ocorrem em condições muito diferentes: algumas emigram com seus pais ainda muito pequenas, outras nascem no Japão; existem aquelas que vão já crescidas, com algum domínio ou sem qualquer conhecimento da língua e da cultura japonesas; algumas estudam em escolas brasileiras ou em escolas para filhos de estrangeiros, outras frequentam escolas japonesas; parte delas mantém contato diário com os pais por períodos maiores e falam português em casa, outras pouco veem seus pais no dia a dia e se distanciam cada vez mais da língua e cultura brasileiras; enfim, as experiências são heterogêneas. Quando retornam com os pais, acontece a mesma situação, ou seja, as idades variam muito, o domínio da língua portuguesa também, o estranhamento da cultura brasileira não é sentido da mesma maneira ou com a mesma intensidade; enfim, as situações são díspares, mas cada uma traz suas dificuldades para a readaptação ou adaptação à cultura brasileira. E a escola será um desses lugares onde as dificuldades e os desafios das crianças filhas de dekasseguis aparecem com maior visibilidade.

É exatamente a experiência de crianças e adolescentes, filhos de dekasseguis, que a autora retrata e analisa neste livro, fruto de uma longa pesquisa na qual acompanhou alguns casos durante anos, realizando entrevistas clínicas. A perspectiva e o olhar dos pais também são considerados, mas é a ótica da criança que é contemplada neste trabalho. Acompanhando essas crianças, desde quando regressaram ao Brasil com seus pais, a autora mostra, mediante trechos de falas, desenhos e outras formas de expressão, como as crianças e adolescentes percebem e sentem sua condição de imigrante. É possível compreender, nos relatos das crianças, os sentidos que o Japão tem para elas, como avaliam sua vida naquele país, os vínculos e identificações que ainda preservam com a cultura japonesa, as dificuldades e estranhamentos que sentem diante da cultura brasileira, os impasses que vivem, o desejo de retornar ao Japão, e assim por diante.

Aliás, é na criança que se configuram as experiências mais radicais da imigração. É nela que se materializam os confrontos culturais, 
os choques subjetivos e os choques educacionais. É ela que vive, com maior intensidade, o hibridismo cultural, social e psíquico. É nela que as forças cinéticas escavam seus sulcos. Contudo, ela é a maior depositária e beneficiária dos enriquecimentos produzidos pela transnacionalidade, transculturalidade e transubjetividade. É portadora de um capital cultural e subjetivo ampliado pela convivência com hábitos, costumes, valores, tipos de organização e de relacionamentos sociais, linguagens, formas de ser e existir provenientes de espaços do mundo bem distintos.

Como eminentes sujeitos desse tempo de movimentação, produtor de trajetividades e mudanças constantes, são elas, mais precisamente os filhos de imigrantes, que constituem os principais autores e protagonistas das narrativas transubjetivas da atualidade. Portanto, podemos tomar os filhos dos imigrantes, os filhos dos dekasseguis, como modelo de sujeitos e de subjetividades que estão despontando e indicando tendências rumo ao futuro. Ao analisar o caso específico das experiências de imigração dos filhos dos dekasseguis, este livro nos permite refletir sobre a vida contemporânea e suas vicissitudes.

José Sterza Justo Docente do Programa de Pós-Graduação em Psicologia Unesp-Assis 


\section{Prólogo}

Este tema de pesquisa estabelece um forte vínculo com minha experiência de vida. Fui uma dekassegui, ${ }^{1}$ vivi intensamente essa experiência e, se não fosse por isso, talvez dificilmente teria elegido esse tema de pesquisa para o meu mestrado.

Durante o forte movimento dekassegui, na década de 1990, meu marido e eu também fomos tomados pela ideia de trabalhar no Japão, já que conhecíamos muitos descendentes que estavam na "Terra do Sol Nascente". O meu marido é descendente de japonês da chamada terceira geração, ou seja, é um sansei. ${ }^{2}$ Pensávamos na construção de um futuro próspero. Eu, recém-formada em psicologia, e meu marido, bacharel em direito, na época funcionário público. Deixamos tudo. Partimos para o Oriente em busca de realizações pessoais. Algo muito intenso alimentava a ideia de tentar a vida no Japão. Entretanto,

1 Dekassegui: originado do japonês Deru (sair) e Kasegu (ganhar dinheiro). Aquele(a) que sai para trabalhar fora em serviços temporários para ganhar dinheiro. Anteriormente, o termo dekassegui era usado para os japoneses das ilhas do norte e nordeste que se deslocavam temporariamente para as regiões do sul do Japão em busca de trabalho para fugir dos invernos rigorosos da região. Entretanto, o termo dekassegui também é usado para os descendentes de japoneses que se deslocam para o Japão em busca de trabalhos temporários.

2 Sansei: Sansei (mf), cidadão (cidadã) brasileiro(a) neto(a) de emigrante (imigrante) japonês; terceiro(a) (Hinata, 1998, p.373). 
sabíamos que não seria fácil. Estávamos cientes das dificuldades. Tínhamos em mente as questões das diferenças culturais, a língua japonesa, a comida, o sistema de trabalho em ritmo acelerado, a rigorosa disciplina. Porém, a primeira impressão de estranhamento veio quando estávamos no avião, sobrevoando o território japonês. Comecei a sentir tudo aquilo como estranho e desconhecido, nada familiar para mim. O desejo era de não descer ali, ou psicanaliticamente falando, não refazer, naquele momento, o que parecia ser outro nascimento. Mesmo não sendo o interior de um avião um ambiente familiar para mim, me soava, naquele instante, como um lugar de aconchego e proteção que poderia me levar de volta à terra-mãe e me livrar daquela que, do alto, parecia inóspita. A primeira sensação no solo, ainda dentro do aeroporto de Nagoya, foi de um calor até reconfortante, mas que se dissipou rapidamente e foi substituída por uma sensação do frio intenso que fazia, uma temperatura abaixo de zero, naquele 31 de dezembro de 1996. A recepção foi feita por um funcionário da empreiteira onde iríamos trabalhar e um casal de parentes. Fomos para o estado/província de Shizuoka, localizado na região central do Japão. Assim começava minha história de vida como dekassegui.

Esta história não se difere de tantas outras vivências de muitos que partem em busca de sucesso profissional e financeiro no Japão e se separam de seus familiares, amigos, de seus objetos amados, em busca de algo desconhecido, novo e idealizado. Uma mudança radical como essa, vivenciada pelos dekasseguis quando desembarcam no Japão e travam os primeiros contatos com essa terra tão distante e diferente, dispara sensações, sentimentos, afetos, pensamentos, imaginações de todo tipo. É uma verdadeira tempestade emocional, sobretudo porque, diferentemente de um viajante temporário ou de um turista, o dekassegui não se depara com uma paisagem curiosa ou de lugar exótico para ser contemplado, experimentado levemente e tateado à distância, mas, sim, encontra-se em um lugar absolutamente estranho, no qual irá viver por certo tempo e terá de produzir suas condições de existência.

Mesmo em companhia de familiares, como era o meu caso, o desamparo e a insegurança, quando não alguma persecutoriedade 
acompanhada de desconfiança e da percepção de um ambiente hostil, são sentimentos inevitáveis. O desamparo parece ser o sentimento básico nessa experiência, desencadeado pela sensação e percepção de perda das ancoragens e dos referenciais de si mesmo estabelecidos ao longo da vida assentada num determinado lugar; de perda do entorno geográfico, social, cultural e psicológico, até então fixo, estável e bastante familiar.

No Japão, trabalhei como operária numa fábrica. As dificuldades iam aparecendo diariamente. O serviço era árduo, acelerado, e havia uma grande exigência das chefias, normalmente ocupadas por japoneses natos. O funcionário que errava se tornava uma "máquina estragada" e imprestável para exercer sua função na fábrica. Meu objetivo e do meu marido era conseguir fazer uma boa poupança para retornar ao Brasil. Voltávamos ao alojamento após doze horas de trabalho. Optamos por morar no alojamento. Era pequeno e sem conforto. Tínhamos a intenção de economizar o quanto fosse necessário. Quanto à questão da adaptação, foi acontecendo aos poucos, mas nos primeiros meses sentíamos saudades da família e da comida brasileira. A língua japonesa fez com que eu me sentisse um bebê que vai aprendendo as primeiras palavras no seu ambiente de convivência, assolado pelo desejo de se comunicar, de se fazer entender e entender os outros. As saudades do Brasil e dos meus familiares permaneceram durante os oito anos que morei no Japão. Como dekassegui, me sentia insegura, ameaçada e em perigo. Não tinha garantia de emprego e muito menos de moradia. Os administradores da empreiteira abusavam do seu poder, intimidando os funcionários de despejo se não os obedecessem. Sob ameaças e sem forças para quaisquer enfrentamentos, a tendência é ir se anulando e contendo impulsos e desejos à custa de muito sofrimento.

O tempo foi passando e a esperança de retornar era o que mais alimentava minha vida. Para tornar a situação ainda mais problemática, a economia japonesa começou a entrar em recessão. A insegurança aumentava por viver num país desconhecido; sentia-me sozinha e ameaçada de perder o emprego, totalmente desprotegida. 
A saída do Japão, onde permanecemos por oito anos, foi uma experiência de deixar a terra que não simbolizava a mãe natural, mas que acabou tratando bem seus filhos adotados, imigrantes, dando-lhes o sustento e uma poupança adicional. De terra estranha e distante, passou a me soar como próxima e familiar, produzindo significações emocionais e criando um espaço mental de lugar de morada por tempo determinado e de estabelecimento de laços de amizade e de absorção de crenças, práticas e valores, como a rígida disciplina, por exemplo, que muito estranha os brasileiros. Mal sabia que o retorno não seria tão menos problemático do que fora a saída do Brasil. Depois desses oito anos no Japão, a partida ressuscitou novamente o fantasma da separação, trazendo-me de volta sentimentos de dor, perda e medo do novo. No Brasil, seria um reinício, uma readaptação ao sistema brasileiro e a reconquista de um novo espaço.

Ao chegarmos ao país de origem, tivemos a percepção de que ele não era propriamente desconhecido, mas que estava diferente, ou seja, modificado pelo tempo, dando-nos uma sensação de estranheza. O crescimento e desenvolvimento da cidade, as feições das pessoas não eram mais aquelas dos orientais, às quais já havia me habituado. Novamente nos deparamos com o choque cultural, talvez até pior do que aquele vivido na chegada ao Japão porque, agora, tratava-se de retificar registros fortemente estabelecidos e que não mais correspondiam ao que percebíamos e sentíamos. Ressurgem o medo, o perigo e o desamparo psíquico nessa percepção de estar duplamente expatriado ou desfiliado: nem a mãe natural, nem a adotiva. No retorno, senti na pele o que é a chamada experiência de se constituir como sujeito no "entre", ou seja, no espaço que liga dois lugares; que está entre dois lugares distintos. Nem aqui, nem lá, mas entre os dois. Nas primeiras sensações do retorno, me sentia exatamente assim: nem no Japão, nem no Brasil. Fora de um lugar e agora inteiramente desamparada porque, se antes, ao chegar ao Japão, podia me refugiar nas lembranças acolhedoras do Brasil, agora nem sequer a lembrança era um porto seguro; aliás, as lembranças eram o maior fator de instabilidade e insegurança, pois a cada momento sentia que o que havia deixado para trás na primeira partida já não estava mais ali. 
Mesmo com o passar dos anos do retorno e com a readaptação razoavelmente realizada, não deixei de reconhecer como parte inextrincável de mim o que resultou dessa experiência radical como dekassegui. Seguramente, nem sequer conseguimos reconhecer com muita clareza o que uma experiência como essa suscita e perceber suas influências no modo de ser atual. Essa proposta de pesquisa é, indubitavelmente, mais um desdobramento da minha experiência como dekassegui, e espero conseguir, por meio dela, trazer alguma contribuição ao conhecimento do fenômeno migratório, cada vez mais proeminente na atualidade.

A minha experiência de viver um longo período no Japão fortalece a impressão que já tinha sobre as dificuldades das crianças dekasseguis. Perante a atual e dura realidade dos filhos de dekasseguis que vivem no Japão, pude confirmar o desamparo psíquico desencadeado pelas longas ausências diárias dos pais e pela dificuldade de aprender o novo idioma, e talvez o único de seu conhecimento. É importante lembrar que muitas dessas crianças nasceram no Japão e frequentaram escolas japonesas, sempre correndo atrás do atraso escolar.

De forma sucinta, não poderei deixar de comentar e escrever sobre a minha segunda viagem para o Japão, que posteriormente pretendo descrever no doutorado. Não poderia imaginar que tão logo retornaria à "Terra do Sol Nascente". O convite para participar do "Programa de Desenvolvimento de Apoio Psicológico no Estado de São Paulo voltado aos dekasseguis e seus descendentes que retornam ao Brasil" veio da Dra. Mary Yoko Okamoto, coordenadora do projeto e professora da Faculdade de Ciências e Letras da Universidade Estadual Paulista "Júlio de Mesquita Filho" - Campus de Assis (FCL/Unesp). Esse trabalho teve início em 2012 e está sendo realizado pela Unesp de Assis em parceria com a JICA (Japan International Cooperation Agency). O retorno para o Japão aconteceu no dia 3 de setembro de 2012, juntamente com a coordenadora e mais duas colegas psicólogas que também participam do projeto. A coordenadora permaneceu no Japão por quinze dias, enquanto minhas colegas psicólogas e eu ficamos por um período de três meses, cada qual em um estado/província japonesa. 
A princípio, surgiu em mim um sentimento de felicidade por poder retornar ao Japão, onde morei e trabalhei por longos oito anos, acompanhada do meu esposo. Fiz dessa "terra" a minha "casa". A percepção do reencontro com a terra japonesa novamente veio no avião. Estava muito ansiosa de como encontraria a minha terra adotiva, a japonesa. Desta segunda vez, tive a sensação de que a terra nipônica não era mais seca, e sim estava arborizada e diferente do primeiro contato ocorrido em 1996. A paisagem mudara, estava mais bonita de se ver e apresentava um aspecto mais agradável.

As diferenças vão surgindo quando nos deparamos diretamente com o solo japonês. Agora encontrava-me em outra condição: não era mais uma "imigrante dekassegui", era uma "estrangeira" num país que era "familiar". Apesar da "familiaridade", o tempo surge como "outro", ou seja, "outro tempo" - as pessoas não são as mesmas, nem o lugar é o mesmo de antes. Apesar de estar acompanhada, senti que era um novo momento da minha vida e igualmente desconhecido, não sabia o que realmente os japoneses esperavam do nosso trabalho. Surgiram vários sentimentos: a insegurança, o medo de errar, a impotência, a tristeza e, algumas vezes, a sensação de desamparo. Encontrava-me sozinha, na cidade de Nagoya, hospedada no hotel da JICA.

A cada dia percebia o quanto de Japão existia em mim. Apesar do meu limitado conhecimento da língua japonesa, considero-a a principal problemática da comunicação no mundo nipônico, por ser uma língua muito difícil e totalmente diferente da nossa. Sentia a necessidade de "querer compreender o outro" e "de desejar ser compreendida por esse outro" no novo momento de vivência oriental. Entretanto, dessa vez, não cheguei somente com o Brasil, mas também com um Japão que se encontrava adormecido dentro de mim. O contato do dia a dia com o território e com os japoneses natos foi despertando as palavras, expressões nipônicas, comportamentos mais contidos, hábitos, o paladar. No entanto, não cheguei totalmente "vazia" como da primeira vez. Já não era mais considerada um bebê recém-nascido, psicanaliticamente falando; já tinha oito anos de vida nipônica. Portanto, estava crescida, embora ainda não soubesse me comunicar fluentemente na língua japonesa. 
Durante essa nova experiência de vida, fica nítida a "condição de ser estrangeira" nesse país. Os japoneses desejavam me "escutar", diferentemente de quando era uma "imigrante", uma simples operária, e "nunca era escutada". Duas experiências tão diferentes, vividas pela mesma pessoa, como dizem os compositores Fernando Brant e Milton Nascimento (1985) na música "Encontros e despedidas": "[...] são só dois lados da mesma viagem, o trem que chega é o mesmo trem da partida [...]". No momento anterior, como "imigrante dekassegui", o palco da vida era outro. O cenário muda completamente, a paisagem não é mais a mesma. Nesse novo cenário no Japão, eu era a estagiária da JICA, ou seja, a psicóloga que partiu do Brasil para o Japão com o propósito de contribuir com a nova e difícil realidade da família dekassegui. Como "imigrante", o vértice era outro. Ouvia dos japoneses líderes da fábrica a palavra dame, ${ }^{3}$ ou seja, "não pode", e, como "estrangeira", só ouvia a palavra daijōbu, ${ }^{4}$ que quer dizer "tudo bem”, "pode" (no sentido de aprovação). Duas palavras tão próximas: "imigrante” e "estrangeiro", vividas no mesmo mundo de formas tão distintas.

Diante da nova realidade, agora como psicóloga, numa "condição de estrangeira”, ou seja, numa condição de retorno muito melhor do que a "condição da chegada do imigrante dekassegui no Japão", constato que muda a forma de tratamento dos japoneses em relação à condição profissional no país. Como estrangeira em terras nipônicas, sentia-me acolhida pelos japoneses, e o sentimento de desamparo era mais atenuado.

Na condição de imigrante dekassegui, o sentimento de desamparo permaneceu durante os oito anos de Japão, teve continuidade e foi intensificado no retorno ao Brasil. Nessa segunda viagem ao Japão, esse sentimento foi menos ameaçador; sentia-me mais segura. Já o sentimento de desamparo para o imigrante dekassegui parece ser constante, não cessa nunca, não tem fim; é como se o sentimento de

3 Dame: [adj-v] inútil, ruim; sem esperança; impossível; dever, não poder (Ohno, 1989, p.87).

4 Daijōbu: [adj-v] seguro; certo (Ohno, 1989, p.83). 
desamparo o acompanhasse e fizesse parte do seu destino na condição de imigrante.

Foram duas experiências bem distintas, cada uma despertando determinados sentimentos, afetos, e provocando reflexões específicas, que me impeliam a examinar minha própria vida e também a daqueles que, tal como eu, se dispuseram a ir tão longe e a enfrentar tantos desafios.

Entre as tantas questões que poderia formular em torno da experiência dos dekasseguis, elegi uma que não me atingiu diretamente, mas que me sensibilizou bastante: a dos filhos dos imigrantes. Não tive filhos, mas me tocava profundamente e me chamava bastante a atenção esta situação dos filhos dos meus conterrâneos dekasseguis. Se para os adultos os desafios eram grandes, para as crianças como seria, de repente, estar em "outro mundo", seja tendo nascido no Brasil, ou tendo nascido no Japão? Como as crianças elaboram as referências das duas culturas com as quais têm contato direto ou indireto? Como ocorre sua adaptação nas mudanças de país? Quais seriam as dificuldades ou choques de ser uma criança brasileira no Japão ou uma japonesa no Brasil?

São essas indagações que pretendo tomar como guia para esta pesquisa. 


\section{INTRODUÇÃO}

Embora o fluxo de deslocamentos de brasileiros descendentes de japoneses para o Japão tenha sido intenso, sobretudo nas décadas de 1980 e 1990 - produzindo uma série de consequências tanto no plano econômico como no psicológico e no das relações familiares -, pouca atenção foi dada pela ciência a esse fenômeno denominado dekassegui, cujas primeiras grafias tentavam registrar a sonoridade dessa palavra na língua japonesa, ou "decasségui", tal como já foi dicionarizada na língua portuguesa falada no Brasil.

De acordo com Portes, Guarnizo e Landolt (1999), a migração de ida e volta dos imigrantes sempre existiu, não atingindo até o momento atual um volume crítico e a complexidade efetiva para se lançar no campo social emergente. Esses imigrantes são pessoas que vivem em dois lugares, falam dois idiomas e mantêm contatos contínuos entre ambos os países.

O movimento de retorno dos dekasseguis ao Brasil vem ocorrendo em razão das várias recessões econômicas no Japão que têm se prolongando por muito mais tempo no país de destino. Nesses últimos anos, o retorno dos dekasseguis ao Brasil vem se tornando um problema social e despertando nas ciências um novo olhar para esse trânsito migratório, apesar de ainda ser tímido o interesse por esse grupo. 
Para piorar ainda mais a situação política e econômica japonesa, além da crise da falência imobiliária dos Lehman Brothers, ${ }^{1}$ em 2008, que atingiu a economia mundial, o Japão vem sendo afetado por grandes maremotos e pela radiação nuclear decorrente desses grandes abalos sísmicos, que continuam sendo uma ameaça para quem mora no país.

Para o ex-presidente da ACEMA (Associação Cultural e Esportiva de Maringá), o senhor M. Hossokawa (apud Asari; Tomita, 2000, p.54), "[...] o que era para ser uma alternativa de vida, vem se tornando um problema”. Nessas idas e vindas entre Japão e Brasil, os dekasseguis, ao retornarem para a sua terra natal, se deparam com a falta de emprego e formação profissional, desencadeando o "movimento pendular" (Asari; Tomita, 2000, p.54).

Diante dos fatos, essas idas e vindas dos dekasseguis estão cada vez menos frequentes. Por causa da crise econômica japonesa, o próprio governo japonês vem fechando as portas de entrada do país, aplicando medidas provisórias de cunho político e socioeconômico, a fim de segurar o país em razão da falta de emprego em que se encontra.

Surge um novo fluxo migratório, desta vez com expressivos contingentes de dekasseguis que retornam ao Brasil. Esse fluxo de retorno traz novos desafios para os migrantes. Agora, é um retorno para a terra natal - o Brasil -, como se, em virtude do fim da "era de ouro" que marcou a grande onda dekassegui, fosse a última e definitiva viagem. Podemos dizer que, além das dificuldades de retorno encontradas pelos dekasseguis, atualmente surgem outras: o corte da facilidade de voltar ao Japão, como se fosse necessário lidar com um "fim", mesmo que esse "fim" seja por um tempo indeterminado, ainda não previsto.

"Voltar é muito mais difícil que partir" - é assim que os emigrantes dizem se sentir a respeito do retorno para o solo natal, o

1 A crise imobiliária do Lehman Brothers ocorreu no final de 2008, nos Estados Unidos da América, afetando financeiramente todo o planeta. O banco de investimentos Lehman Brothers é o quarto maior dos EUA (Lehman..., 2008). 
retorno para casa. O problema do retorno para a terra de origem é muito mais complexo do que se imagina. Depois de uma temporada de vida e trabalho em outro país, com uma cultura tão diferente da brasileira mesmo para os descendentes, os emigrantes são profundamente afetados, assumindo ou aprofundando uma identidade híbrida, incrustada na sua história familiar - uma identidade transnacional (Assis; Campos, 2009).

Segundo Tajiri e Yamashiro (1992 apud Deliberador, 2011), são vários os fatores que fazem o homem se deslocar de um lugar para o outro, e, ao longo de toda a história da humanidade, não tem sido diferente. O homem transita, tentando desbravar o desconhecido, seja por questões políticas, econômicas, sociais, religiosas e tantas outras.

A restauração da Era Meiji, em 1868, trouxe novas transformações políticas e econômicas ao Japão. O sistema moderno de Estado acaba afetando a economia e gera altas taxas de desemprego no país. Diante desse período tão difícil vivido pelos japoneses, a alternativa que lhes restava era migrar para o Brasil, já que, no começo do século XX, o Brasil contratava mão de obra para as lavouras cafeeiras no estado de São Paulo. A imigração japonesa tem início com a chegada do navio a vapor Kasatu Maru, em 18 de junho de 1908, no porto de Santos (Deliberador, 2011).

Ressalvamos que os primeiros dekasseguis a chegarem ao Brasil vieram nesse fluxo migratório de japoneses, a 18 de junho de 1908. Esses imigrantes tiveram que enfrentar a dura realidade da época, o estranhamento entre países tão distintos, as dificuldades da língua, a comida, o clima, entre outras eventualidades.

Antes de completar um século da imigração japonesa no Brasil, a década de 1980 conheceu o fenômeno que ficou conhecido como dekassegui. Agora, são os descendentes de japoneses que se deslocam do Brasil para trabalhar como operários nas fábricas japonesas, buscando melhores salários e enriquecimento rápido.

Legalmente, a imigração de japoneses para executar trabalhos pouco qualificados no Japão se deu a partir de 1991. A população local, de alto nível de instrução, opta por trabalhos técnicos e 
específicos, o que resulta na necessidade de mão de obra imigrante para os trabalhos indesejáveis. Paralelamente, no fim dos anos 1980 e início da década de 1990, o Brasil passava por um processo extremamente penoso, de mudança de moeda e hiperinflação, resultando na desvalorização da força de trabalho e descapitalização dos salários. Essa situação favoreceu o movimento "dekassegui". (Osawa, 2006)

De acordo com Sasaki (1999, p.243), a palavra dekassegui significa "trabalhar fora de casa"; portanto, é o indivíduo que trabalha fora, vindo de outras regiões ou de outros países. Esses trabalhadores, de maioria braçal, foram contratados para fazer o serviço sujo, penoso e perigoso, ou seja, o trabalho que os japoneses não queriam fazer. Logo, realizam serviços de baixa qualificação na terra dos seus avós.

Ito (2007 apud Amaral; Cores; Matsuo, 2010) destaca, no movimento dekassegui, a situação das crianças nas famílias que se mudam para o Japão com filhos em idade escolar. Enquanto permanecem no Japão, as crianças brasileiras ingressam nas escolas japonesas. Lá não aprendem o idioma português, tendo portanto que se adaptar ao modelo escolar japonês, muito diferente do modelo implantado em nossas escolas. As dificuldades e a demanda são tamanhas que existem escolas brasileiras para atender especialmente os filhos dos dekasseguis.

São inúmeras as dificuldades que vão surgindo para esses imigrantes quando em terras estrangeiras, tais como: novos hábitos; a língua japonesa; a comida "não temperada" ou "sem sal" (como é sentida gustativamente), bastante diferente do tempero brasileiro, que se acentua ao sabor do sal e de outros condimentos na comida; o ritmo acelerado de trabalho; a moradia pequena e, às vezes, sem nenhum conforto; a própria adaptação dos filhos, sobretudo nas escolas e com as longas ausências diárias dos pais operários; a distância do Brasil; e tantas outras. No turbilhão de estranhamentos e dificuldades, em vista do choque cultural, é comum surgir o sentimento de desamparo. O desejo de retornar para o Brasil está intrinsecamente vinculado ao imigrante dekassegui, entretanto, uma grande parte dos descendentes de japoneses opta por morar no Japão. 
O retorno ao Brasil não é menos problemático. Apesar de considerarem-no seu solo natal, acabam trazendo consigo um pouco do Japão e um Brasil dentro de si que nem sempre corresponde inteiramente àquele que encontram no retorno, sobretudo depois de certo tempo de ausência. Logo, como sujeitos híbridos, carregam a cultura de dois países que são extremos opostos, amalgamada numa subjetividade duplamente social. Se tais choques, contrastes e vivências díspares são problemáticos para os adultos, para as crianças a situação também não é simples, mesmo com suas especificidades.

Nessa perspectiva, Asari e Tomita (2000, p.54) argumentam "que as experiências mais amargas têm ocorrido com os filhos que acompanharam os pais e tiveram que frequentar as escolas em dois países”. No Japão, os filhos menores de 16 anos de idade são obrigados a frequentar a escola, caso contrário os pais podem ser penalizados.

Os referidos autores apontam, ainda, que esses filhos de dekasseguis interromperam os estudos no Brasil e tiveram que estudar em escolas japonesas e, diante do sistema japonês, enfrentam "[...] a discriminação e as dificuldades de adaptação, principalmente no que respeita a não compreensão da língua japonesa" (Asari; Tomita, 2000, p.55). E ao retornarem para o Brasil, novamente as crianças se deparam com problemas de "readaptação psicológica, emocional, somada à nova adaptação curricular" (Asari; Tomita, 2000, p.55).

Observa-se que o aprendizado da língua portuguesa constitui um fator de grande sofrimento emocional para esses filhos de dekasseguis quando voltam ao Brasil.

No já restrito campo das produções científicas sobre as questões dos dekasseguis, os estudos sobre seus filhos são igualmente escassos, considerando-se a importância e a amplitude das questões que emergem nessa experiência dos infantes. Entre as pesquisas existentes, predomina a preocupação com os aspectos econômicos da situação dos dekasseguis e com as dificuldades de adaptação escolar das crianças. Assim, neste livro, pretendemos abordar uma questão básica do desenvolvimento psicológico, bastante mobilizada nessa experiência: a questão do desamparo psíquico. 



\title{
1. \\ FENÔMENO MIGRATÓRIO
}

\section{Fenômeno migratório: o caso dos dekasseguis}

\author{
Viejas como el hombre, las migraciones humanas \\ han sido encaradas desde muchos puntos de vista. \\ Numerosos estudios han considerado las impli- \\ caciones históricas, demográficas, culturales, \\ religiosas, políticas, ideológicas, económicas, etc., \\ de las migraciones, implicaciones que son, sin \\ duda, importantes y trascendentales. (Grinberg; \\ Grinberg, 1984, p.11)
}

\section{O Homo viator}

Diversas características têm sido tomadas como centrais no homem e consideradas as primeiras responsáveis pelo seu desenvolvimento enquanto uma espécie animal bastante diferenciada. A inteligência foi uma dessas características tão fundamentais que deram ao homem a alcunha de Homo sapiens. ${ }^{1}$ Outras qualidades

1 Homo sapiens: "O Homo sapiens (homem inteligente) seguiu-se ao Homo erectus. Os cientistas sabem pouco acerca de como o Homo sapiens substituiu o 
também foram enfatizadas mediante tantas outras denominações, tais como: Homo erectus, ${ }^{2}$ Homo sacer, ${ }^{3}$ Homo habilis, ${ }^{4}$ Homo faber, ${ }^{5}$ Homo ludens, ${ }^{6}$ e assim por diante.

Homo erectus. Essa transformação ocorreu em épocas diversas, em diferentes partes do mundo. Uma forma primitiva do Homo sapiens pode ter se transformado no tipo humano atual por volta de 300.000 a.C., na África e na Europa, e por volta de 100.000 a.C. na Ásia oriental" (Enciclopédia Delta Universal, 1980, p.4057).

2 Homo erectus: "Os primeiros seres humanos. Por volta de 1.200.000 a.C., havia surgido uma forma de ser humano primitivo mental e fisicamente mais avançado do que os australopitecos. Os indivíduos tinham a altura de $150 \mathrm{~cm}$ e uma ampla fronte obliquamente recuada, maxilar proeminente e um cérebro com cerca de duas vezes o tamanho de um australopiteco. Os cientistas denominam esse tipo de ser humano pré-histórico de Homo erectus (homem ereto). O Homo erectus vivia na África, na Ásia e na Europa. Usava ferramentas talhadoras e machadinhas de mão. Aprendeu a produzir fogo e provavelmente foi o primeiro a usar vestimentas" (Ibid., p.4056).

3 Homo sacer: de acordo com Gomes (2012, p.32), "o Homo sacer, ou homem sagrado, representava, na Roma antiga, a pessoa que podia ser banida ou morta por alguém, mas que não podia ser sacrificada em rituais religiosos. Essa pessoa não possuía direitos e era considerada amaldiçoada".

4 Homo habilis: "Ancestrais Antropoides: Os cientistas pensam que os primeiros seres humanos provieram de criaturas antropoides, isto é, parecidas com o homem, chamadas australopitecos, nome que vem do termo científico da espécie Australopitheus (símio da região sul). [...] surgiram inicialmente há mais de cinco milhões de anos. Quase todos os fósseis de australopitecos foram descobertos no sul e no leste da África. Os pesquisadores descobriram também uns poucos fósseis de australopitecos em Java, uma ilha do sudeste da Ásia. Alguns estudiosos admitem que essas criaturas foram os primeiros seres humanos existentes, e que devem ser chamados de Homo habilis (homem hábil). A partir de meados da década de 1960, os cientistas descobriram muitos fósseis de australopitecos na África Oriental. Descobriram também ferramentas de pedra num sítio arqueológico que data de cerca de 2.600.000 a.C.” (Ibid., p.4056).

5 Homo faber: filogeneticamente Homo significa gênero dos primatas do qual a espécie humana faz parte, e faber define o estágio do qual torna-se capaz de fazer e fabricar ou criar. Max Frisch (1957 apud Kanaan, 2013) define o Homo faber como aquele que constrói o seu próprio destino.

6 Homo ludens: a tese central da obra Homo ludens é a de que o jogo é uma realidade originária, que corresponde a uma das noções mais primitivas e profundamente enraizadas em toda a realidade humana, sendo do jogo que nasce a cultura, sob a forma de ritual e de sagrado, de linguagem e de poesia, permanecendo subjacente em todas as artes de expressão e competição, inclusive 
Outra característica que não poderíamos deixar de destacar como central para a construção da humanidade é a mobilidade, ou seja, a capacidade e disposição do homem para se deslocar, para sair de um lugar e ir para outro. Marcel (1967) considerava tão importante a itinerância do homem que não teve dúvidas em considerá-lo como Homo viator. Rouanet (1993), na mesma linha de pensamento, enfatiza que a essência do homem é viajar, mesmo que sejam viagens fortuitas e fugazes, como essas atuais que turistas fazem a lugares como a Disneylândia. Ainda que não se queira considerar a movimentação humana como um traço fundamental, segundo Maffesoli (2001, p.21), em Sobre o nomadismo, a mobilidade do homem é decorrente do desejo que o movimenta, que o pulsiona constantemente para o deslocamento, traz com ele a pulsão da andança, "o desejo de errância como sede do infinito".

Ainda que não se considere a mobilidade como um traço central, indubitavelmente ela é uma importante parte constitutiva do homem. Ao lado da sabedoria, da capacidade laborativa, da postura ereta e de tantas outras estão também a itinerância, o nomadismo, a errância, a andança, enfim, a disposição e a habilidade do homem para realizar deslocamentos no plano geográfico, social, psicológico e cultural.

Entre as diferentes experiências humanas de deslocamento e mobilidade encontramos as que se expressam no chamado fenômeno migratório. $\mathrm{O}$ conceito de migração não é simples e tampouco existe consenso em torno dele. De maneira geral, refere-se a deslocamentos de um lugar a outro, a movimentações que possuem uma origem e um destino imbuídas de um propósito, de se fixar ou residir em outro território. Tais movimentações tendem a formar fluxos de trânsito de uma região a outra, dentro de um mesmo país, como no caso das chamadas "migrações internas", ou fluxos de movimentações entre diferentes países ou continentes, como ocorre com

nas artes do pensamento e do discurso, bem como na do tribunal judicial, na acusação e na defesa polêmica, portanto, também na do combate e na da guerra em geral (Albornoz, 2009). 
os chamados "migrantes internacionais", comumente designados "imigrantes". Os fluxos de partida foram nomeados "emigração" e os da chegada ao destino, "imigração". Paralelamente, surgiram os conceitos de "emissão" e "recepção" para caracterizar regiões ou países de onde partiam ou aonde chegavam os migrantes.

No mundo atual, o conceito de migração se torna ainda mais complexo, em razão do aumento vertiginoso das diferentes formas de mobilidade e de trânsito entre uma localidade e outra, entre regiões geograficamente distantes, entre países, continentes e entre povos e culturas marcadamente diferentes. Hoje, diferentemente de outras épocas, são comuns os intercâmbios culturais e científicos e tantas outras viagens, a saber, com duração bastante variável. É possível permanecer em um lugar longínquo por alguns dias ou por uma longa temporada ou, ainda, ter domicílios em diferentes países. Por exemplo, são considerados "migrantes regionais" cantores e demais artistas que se deslocam do Nordeste brasileiro para se fixar no Rio de Janeiro ou em São Paulo. Santamaria (2002) chama a atenção para o fato de que o fenômeno migratório é uma construção fortemente assentada no imaginário social e em formações discursivas transpassadas por relações de poder, interesses econômicos e políticos, e por dinamismos psicológicos. Dessa forma, o "imigrante" carrega consigo, frequentemente, imagens que o retratam como um intruso, perigoso, um ser inferior, incivilizado, e tantas outras características que até podem, inversamente, retratá-lo de forma positiva. Destaca ainda esse mesmo autor que a experiência da imigração se desenvolve, precipuamente, na relação com o estranho, com o desconhecido, no desafio do encontro com um "outro radical", ou seja, com tudo aquilo, especialmente outros seres humanos, que soa como não familiar, como absolutamente diferente.

O caso dos dekasseguis pode ser tomado como paradigmático, enquanto uma experiência de encontro/confronto com o estranho, com o "outro radical". Mesmo sendo descendentes de japoneses emigrados para outros países - como o Brasil e o Peru, na América Latina -, os dekasseguis, ao retornarem para o país dos seus antepassados, confrontam-se com uma cultura e um modo de vida muito 
diferentes daqueles do seu país natal. Vivem uma experiência de estranhamento muito particular, porque não se reconhecem nas imagens daquele outro, de um espelho que, mesmo a distância, fez parte da constituição das referências de si mesmo: a cultura japonesa veiculada pelos seus antepassados que emigraram do Japão e cultivaram hábitos, costumes, a língua, a culinária, tradições e tantas outras referências simbólicas oriundas da terra natal. Portanto, a compreensão das experiências dos dekasseguis, tomadas como experiências fundamentalmente construídas no encontro/confronto com a figura do outro, não se restringe a um caso particular, mas oferece elementos para o entendimento dos desafios que a mobilidade e, consequentemente, os relacionamentos com o estranho colocam para o Homo viator da contemporaneidade.

Fusco e Souchaud (2010) afirmam que a imigração de retorno dos dekasseguis tem sido pouco estudada na América Latina, em virtude da predominância do interesse no fluxo migratório de outras etnias, como a europeia, a asiática e a africana. No entanto, aos poucos, os dekasseguis estão ocupando espaços na ciência e nas políticas públicas, sobretudo com os desafios e problemas gerados pelo retorno desses migrantes ao Brasil, o qual foi intensificado pela desaceleração da economia japonesa nos últimos anos.

\section{A chegada dos japoneses ao Brasil}

Ennes (2001) recupera, em seu trabalho, a trajetória da imigração japonesa no Brasil, destacando a primeira visita oficial japonesa feita, em 1884, pelo deputado Massayo Neguishi, com o propósito de escolher o estado mais adequado para a adaptação dos japoneses ao Brasil. Ele visitou Pernambuco, Minas Gerais e São Paulo, e escolheu o estado paulista por considerar que a terra e o clima proporcionariam as condições ideais para os japoneses fixarem o seu lugar de morada. O primeiro tratado comercial marítimo Brasil/Japão foi firmado em 1895, seguida da iniciativa do governo japonês de enviar ao Brasil um diplomata japonês. "Esse tratado se baseava nos 
seguintes princípios: paz perpétua entre Brasil e Japão, instalação de representação diplomática, liberdade econômica e comercial, isenção de tributos sobre importação e liberdade de consciência, entre outros" (Ennes, 2001, p.49).

Em 1897, foi assinado um contrato entre a Companhia de Imigração Tôyo do Japão e a empresa Prado \& Jordão, prevendo a vinda de 1.500 japoneses para trabalharem nos cafezais paulistas. Porém, a empresa brasileira rompeu o contrato com esses imigrantes. Depois de sete anos, o Japão voltou a pensar no envio dos japoneses ao Brasil. Por intermédio dos veículos de comunicação eram oferecidas propostas otimistas sobre prodigiosas terras e um futuro melhor no Brasil.

Entre 1906 e 1907, o presidente da Companhia Colonizadora Kôkuko, Ryú Mizuno, faz visitas ao Brasil. Na primeira viagem fez um reconhecimento das condições ambientais e agrícolas do Estado de São Paulo. Na segunda, firma com o governo estadual um contrato no qual se estabeleceu a imigração de 3.000 pessoas por ano a partir de 1908. No dia 28/4/1908, parte do porto de Kobe o navio Kasato Maru com destino ao Brasil. Trazia a bordo 167 famílias, num total 761 pessoas, sendo 601 do sexo masculino e 190 do sexo feminino. O navio atracaria 52 dias após no porto de Santos, trazendo sonhos e a esperança de "fazer a América" e depois voltar para a terra natal. (Ennes, 2001, p.50)

Nessa época, o Brasil, por um lado, vivia a expansão cafeeira e necessitava contratar mão de obra para as lavouras de café, e o fluxo de imigrantes italianos havia diminuído drasticamente por iniciativa do governo daquele país. Por outro lado, o governo japonês, numa franca política desenvolvimentista e expansionista, estava interessado em enviar parcelas de seus agricultores de regiões mais pobres para países que eram estratégicos, tais como os da América.

Os imigrantes japoneses, também chamados de dekasseguis, com pouco ou nenhum conhecimento dos interesses de Estado e de empresários que circundavam a arrojada iniciativa de deslocar grandes contingentes de trabalhadores entre os extremos do planeta, vinham 
com o objetivo de acumular dinheiro e retornar para o Japão, galgando uma ascensão social com o presumível enriquecimento obtido no exterior.

O Japão, país de ilhas e arquipélagos, isolado de outros territórios, mantinha peculiaridades no modo de vida de seu povo que eram vistas pelas culturas ocidentais como as de um povo marcado por uma forte rigidez, senso de disciplina, obediência severa, reverência à hierarquia e disposição para o trabalho e para o sacrifício. Mesmo tendo que enfrentar o intenso apego ao solo natal e as estereotipias do olhar dos estrangeiros sobre eles, japoneses tradicionais e empobrecidos se dispuseram a ser aríetes da política de abertura do Japão para o mundo, fustigados pelo sonho de "fazer a América".

Para entendermos melhor a imigração dos descendentes de japoneses brasileiros ao Japão, precisamos voltar ao passado e retomar um pouco a história do país, precisamente o ano 1868. Nessa época, o Japão atravessava um período de grandes mudanças em sua história, na política, nos setores econômicos e sociais. O país deixa de ser um Estado feudal e passa para Estado moderno. Deliberador (2011) relata que a economia dos japoneses, predominantemente centrada na agricultura, passou a ser manufatureira e industrial. Muitos camponeses deixaram suas terras para trabalhar nas indústrias, e esse deslocamento trouxe consequências para o país. A indústria precisava de mão de obra qualificada e não de camponeses despreparados para o trabalho. Em razão dessas transformações políticas no país, muitos camponeses perderam suas terras com a reforma tributária de 1873. Uma década depois, o Brasil vivia o período da abolição da escravatura e estava contratando mão de obra estrangeira nas lavouras cafeeiras. Em 1906, o Brasil vivenciava a crise cafeeira da superprodução e da baixa do preço do café. A imigração japonesa acontece com a chegada do navio a vapor Kasatu Maru, em 18 de junho de 1908, no porto de Santos, quando o Brasil já se recuperava da crise cafeeira.

A Reforma Tributária de 1873 não permitiu mais o pagamento dos tributos em espécie e sim em dinheiro. O reflexo dessa medida 
pode ser observado no fato de que, entre 1883 e 1890, aproximadamente 367.000 lavradores perderam suas propriedades pelo confisco e, entre 1884 e 1886, 1/7 de todo território arável foi perdido por hipotecas. O governo japonês, diante da penúria do campo, não mais impediu a saída dos cidadãos para o exterior. (Deliberador, 2011, p.36)

Em 1902, o governo italiano proibiu a emigração subsidiada, provocando um forte declínio do número desses imigrantes para o Brasil. A crise cafeeira de 1906, decorrente de superprodução e baixa dos preços do produto no mercado internacional, também afetou os movimentos migratórios. Porém, a rápida adoção de políticas de proteção permitiu que houvesse uma acelerada recuperação da economia cafeeira e a retomada da imigração. Nesse contexto, os japoneses, considerados exímios agricultores, passaram a ser vistos pelos fazendeiros brasileiros como uma alternativa de mão de obra para o cultivo do café.

O desembarque dos primeiros imigrantes japoneses foi cercado de curiosidade e de sentimentos díspares. Havia imagens negativas, anteriormente formadas em torno do "perigo amarelo", que incluíam até os chineses, mas também apareceram, nas primeiras observações acerca dos hábitos de conduta dos recém-chegados, imagens de um povo asseado, paciencioso e bem comportado. Iniciava-se um grande e radical encontro/confronto entre duas nacionalidades e culturas bastante distintas.

\section{Desafios do imigrante}

Grinberg e Grinberg (1984) enfatizam que o indivíduo alimenta o desejo de se deslocar, e que, às vezes, esse desejo surge de forma surpreendente, ao passo que em outras ocasiões suscita aspirações impossíveis de se concretizar, resumindo-se a fantasias. Muitas pessoas migram por razões externas, por exemplo, a necessidade financeira, em busca de melhores condições de vida para si e para a família. 
Segundo esses autores (Grinberg; Grinberg, 1984), ao chegar num mundo desconhecido, o imigrante pode encontrar muitas dificuldades internas para se integrar ao meio, por entrar em contato com objetos que lhe soam estranhos, tais como o idioma, os costumes e tantos outros aspectos que compõem o lugar. Surge o temor de não conseguir se comunicar com os outros e consigo mesmo. Esses chamados estados confusionais podem resultar do fracasso de se manter em uma dissociação eficaz e também uma precoce tentativa de integração que ainda não pode ocorrer. O imigrante usa mecanismos de defesa primitivos, como a dissociação e a idealização no novo ambiente a que chegou. Surgem também sentimentos de desvalia e persecutoriedade em relação ao novo lugar e a todas as pessoas que ficaram no antigo ambiente. "Esta disociación le sirve para evitar el duelo, el remordimiento y las ansiedades depresivas que se agudizan por la misma migración, sobre todo cuando se trata de una migración voluntaria" (Grinberg; Grinberg, 1984, p.19).

Tais sentimentos de idealização do novo e desvalorização do antigo são percebidos na experiência migratória como negação da ansiedade e do sentimento de culpa. Grinberg e Grinberg (1984) mencionam outra situação que pode ocorrer, na qual a terra prometida fica desencantada, ou seja, detentora de defeitos, aspectos negativos e persecutórios.

Lo esencial es mantener la disociación: «lo bueno» en un extremo $y$ «lo malo» en otro, no importa cuál de ellos represente una u otra de esas características. Porque, en el caso de fracasar la disociación, surge inexorablemente la ansiedad confusional, con todas sus temidas consecuencias: ya no se sabe quién es el amigo y quién el enemigo, donde se puede triunfar y donde fracasar, cómo diferenciar lo útil de lo perjudicial, cómo discriminar entre el amor el odio, entre la vida y la muerte. Esta confusión puede llegar a ser vivida, entonces, como el castigo por el impulso migratorio, por el deseo de «conocer» un mundo nuevo... distinto. (Grinberg; Grinberg, 1984, p.20) 
Aliás, qual a diferença entre "imigrante" e "estrangeiro"? Por que todos os "imigrantes" não são simplesmente tratados como "estrangeiros"?

Para Grinberg e Grinberg (1984), a migração nomeia a condição da pessoa no lugar, ou seja, ela passa a ser vista e tratada como "emigrante" por aqueles que ficaram no lugar de onde partiu, ou como "imigrante" por aqueles do lugar para onde foi. Passa a ser reconhecida precipuamente como aquela que se desloca de um país a outro ou como alguém proveniente de lugar distinto e distante e que se instala como um intruso no cotidiano alheio, por um determinado tempo, impondo uma convivência cotidiana com os locais. Há uma diferença significativa entre trabalhadores estrangeiros e imigrantes. O trabalhador estrangeiro tem um tempo determinado para retornar ao país de origem e é visto pelos locais mais como um convidado desejado do que um intruso, ao passo que os "imigrantes", mesmo tendo autorização para ingresso e trabalho no país receptor, como é o caso dos dekasseguis, são considerados intrusos, perigosos, não confiáveis e tantas outras atribuições negativas. Formam uma categoria social específica, decorrente do lugar em que são colocados pelas funções que exercem e catalisam nos planos econômico, político, cultural e psicossocial.

Higa (2006, p.47), em sua tese de doutorado Conflitos intrapsíquicos e interpessoais em um grupo de migrantes brasileiros no Japão, traz uma importante e instigante citação de Sayad (1998) sobre a questão da migração:

Estudioso arguto da questão da imigração argumenta que embora possa parecer banal, é importante assinalar que a imigração é um fato social completo. Torna-se pertinente dizer que o itinerário de um imigrante ancora-se no cruzamento das ciências sociais e como o ponto de encontro de disciplinas como história, geografia, demografia, direito, sociologia, psicologia, psicologia social e até mesmo das ciências cognitivas, antropologia, linguística, sociolinguística, ciências políticas, etc. Insiste Sayad que como "fato social total" o fenômeno da imigração diz respeito à sociedade como um todo 
seja na dimensão diacrônica, isto é, numa perspectiva histórica, e também em sua extensão sincrônica, isto é, a partir das estruturas da sociedade e de seu funcionamento. Enfatiza Sayad que o imigrante é aquele que se deslocou fisicamente para um país estrangeiro mas, para fazê-lo, assinala, o imigrante emigrou de seu país de origem. Enfim, imigrante e emigrante são duas faces de um mesmo processo. $\mathrm{O}$ autor adverte ainda sobre a confusão entre estrangeiro e imigrante. Para o autor um estrangeiro é definido enquanto tal até as fronteiras mas continua estrangeiro mesmo além fronteiras, ou seja, durante a permanência no país. Não se trata da mesma situação do imigrante que é definido como estrangeiro até o limite da fronteira. Ultrapassada esta, diz Sayad, deixa de ser estrangeiro para tornar-se imigrante. Se "estrangeiro" é a definição jurídica de um estatuto, "imigrante" é, antes de tudo, uma condição social. (Sayad, 1998 apud Higa, 2006, p.47)

Grinberg e Grinberg (1984) distinguem duas categorias: a dos emigrantes voluntários e a dos emigrantes forçados. Muitos emigrantes são forçados a deixar seu país por motivos sociopolíticos ou até pela ausência de condições mínimas de subsistência. A migração forçada também pode ocorrer em massa, como em 1947 e 1950, quando dez milhões de pessoas foram obrigadas pelos seus governantes a emigrar do Paquistão para a Índia, e, inversamente, sete milhões da Índia para o Paquistão, por questões religiosas. Existe a "no migraciones forzadas", caracterizada por situações em que há o impedimento da entrada de estrangeiros ou da saída de cidadãos para outros países. Muitas pessoas, impedidas de partir, sentem-se presas no país em que vivem e onde não querem permanecer, ao passo que outras desertam e passam a viver como ilegais em outro país.

Há migrações chamadas de "resistencial cambio", conforme apontam Grinberg e Grinberg (1984, p.32). De forma contraditória, a resistência e a troca são migrações de pessoas que se sentem ameaçadas, têm medo de perder os valores, suas condições de vida e partes do próprio eu, e que não conseguem enfrentar seus medos primários. As migrações sedentárias são caracterizadas por pessoas que não 
querem se separar do velho conhecido grupo familiar, ir para o novo desconhecido, tentando permanecer numa condição inalterada, sem modificações.

A veces, paradójicamente, ciertos cambios sociales importantes pueden determinar migraciones por "resistencia al cambio" y el temor a la amenaza de pérdida de valores, de condiciones de vida y, en última instancia, de las partes del self que ese cambio podría involucrar. En estos casos, el individuo no se atreve a enfrentar miedos primarios, como ser el miedo a la pérdida de estructuras establecidas, la pérdida de acomodación a pautas prescritas en el ámbito social, los que generan intensos sentimientos de inseguridad, incrementando el aislamiento, la soledad y debilitando, fundamentalmente, el sentimiento de pertenencia a un grupo social establecido. Muchos de los que emigran por este motivo suelen buscar sitios que, aunque puedan ser lejanos geográficamente, presentan condiciones y características similares a las del lugar de origen, previas al cambio. En estos casos podría hablar de "migraciones sedentarias", ya que se busca rehuir lo nuevo o lo distinto, para recrear y mantener sin modificaciones lo familiar y conocido. Ese irse de un sitio para poder seguir quedándose en lo mismo: es irse para no cambiar. (Grinberg; Grinberg, 1984, p.32)

Alguns autores se preocuparam com aspectos psicológicos da "emigrabilidade" e tentaram construir uma tipologia psicológica dos emigrantes mediante levantamentos de características da personalidade que lhes seriam próprias.

Menges (1959) define el concepto de "emigrabilidad" como "la capacidad potencial del emigrante de adquirir en el nuevo ambiente, en forma gradual y comparativamente rápido, una cierta medida de equilibrio interno que es normal para él - siempre y cuando el nuevo ambiente lo haga razonablemente posible - y que, al mismo tiempo, pueda integrarse en el nuevo contexto sin ser un elemento perturbado o perturbador dentro del mismo". (Menges, 1959 apud Grinberg; Grinberg, 1984, p.32) 
Calvo (1977 apud Grinberg; Grinberg, 1984) enfatiza que as migrações, hoje, estão bastante incorporadas às formas e condições de vida contemporâneas, profundamente marcadas pela mobilidade geográfica, social e psicológica. Não são apenas as motivações econômicas que impulsionam as migrações, mas, sim, todo um conjunto de dispositivos cinéticos que se estabelece no ser humano e o lança na busca de outros lugares para viver, ainda que temporariamente.

Podemos dizer que os desafios do imigrante dekassegui são inumeráveis na transição de um lugar conhecido para outro desconhecido. Justo (2008, p.100) faz uma importante citação em seu texto "A chegada dos imigrantes japoneses e a partida dos decasséguis: Dois lados da mesma viagem":

São muitos os sentimentos que brotam na saga dos migrantes: medo, angústia, culpa, alegria, esperança, prazer e dor. Além dos próprios sentimentos, existem ainda os dos outros que também o afetam, tanto daqueles que ficaram como daqueles que o recebem. Da parte dos que ficaram carregam imagens ambivalentes, talvez de admiração, respeito e reconhecimento, mas quiçá também de inveja e recriminação por terem desertado. Daqueles com os quais passam a conviver são alvo de olhares dúbios, nos quais mesclam sentimentos de simpatia, confiança, compaixão e solidariedade, por exemplo, com sentimento de cobiça, rejeição e escárnio.

Para Justo (2008), os migrantes, ao cruzarem fronteiras e realizarem conexões entre povos e terras distantes, contribuíram para o desenvolvimento econômico, político e cultural da humanidade, além do enriquecimento psicológico possibilitado pelas experiências de enfrentamento de desejos, afetos, sentimentos e cognições candentes que brotam do contato com o estranho, com o não familiar. $\mathrm{O}$ autor acrescenta, ainda, que talvez essa tarefa tenha sido a mais importante e difícil do imigrante: enfrentar o fantasma do desconhecido, do diferente, do outro radicalmente encarnado na figura do estrangeiro. Morar em outras terras é enfrentar o novo e o desconhecido. Ademais, é construir outra "subjetividade". "Formas diferentes 
de pensar, sentir, perceber e falar exigem transformações pessoais profundas que beiram a uma despersonalização ou a um desmanche da identidade pessoal, difícil de ser suportada" (Justo, 2008, p.100).

\section{A chegada dos dekasseguis ao Japão}

La primera migración se remontaría, pues, a Adán y Eva. Estos, impulsados por la curiosidad (simbolizada por la serpiente), se trasladaron a la zona prohibida del Paraíso, donde se encontraba el árbol... "que era Bueno para comer, agradable a los ojos y codiciable para alcanzar la sabiduría"... "Eva comió de su fruto y dio a su marido"... "y fueron abiertos los ojos de entrambos"... "Conocieron el bien y el mal"..., lo que les valió la expulsión-exilio del Paraíso, perdiéndolo con todas sus gratificaciones y condiciones de seguridad y placer. (Grinberg; Grinberg, 1984, p.15)

Na década de 1980, ocorre o fenômeno denominado dekassegui. Desta feita, na direção contrária à da imigração de japoneses para o Brasil, são seus descendentes, aqui nascidos, que se deslocam para o Japão para trabalhar nas fábricas, visando melhores salários e formação de uma poupança. Nesse período, cabe lembrar que o Brasil passava por um momento de crise econômica e política.

De acordo com Sasaki (2004), o Brasil, antes considerado país de destino, país receptor, nas últimas duas décadas tem vivenciado processo inverso. Além de receber trabalhadores migrantes de outros países, o país também passou a enviar pessoas, transformando-se, concomitantemente, em emissor e receptor. Em 1990, o governo japonês restringiu a entrada dos trabalhadores estrangeiros ilegais, medida que facilitou a entrada dos descendentes de japoneses no país.

Diversos autores, ao iniciarem seus trabalhos, tentam compreender o significado da palavra dekassegui como forma de adentrar as primeiras compreensões desse fenômeno. Alguns enfatizam que, etimologicamente, dekassegui significa "trabalhar fora de casa". No 
Japão, o termo dekassegui referia-se especificamente aos trabalhadores que saíam das suas regiões de origem e iam para outras, como os japoneses nortistas e nordestinos que fugiam do inverno rigoroso e improdutivo (Sasaki, 1999, p.243).

Dekassegui refere-se ao termo que designava, originalmente, o japonês que, nos invernos rigorosos, migrava para a cidade grande em busca de trabalho temporário nas indústrias, retornando para o campo após o inverno. Com o tempo, o termo passou a compreender qualquer trabalhador migrante que alimenta o desejo de voltar à terra natal. Nos anos oitenta a expressão dekassegui assumiu conotação pejorativa, por estar associada diretamente à mão de obra sem qualificação. (Miura, 2004, p.192)

Trata-se, portanto, do indivíduo que trabalha fora, vindo de outras regiões ou de outros países. Esses trabalhadores, de maioria braçal, são contratados, tradicionalmente, para fazer o serviço sujo, penoso, perigoso, estafante ou mal renumerado, recusado pelos próprios japoneses. Os dekasseguis atuais, como aqueles provenientes da América Latina, percorreram o caminho inverso de seus pais e avós imigrantes japoneses. Foram à "Terra do Sol Nascente", bem longe de seu país natal, atravessaram oceanos e continentes movidos pelo desejo de concretizar seus sonhos, sobretudo o sonho do enriquecimento, tal como ocorreu com seus avós quando emigraram do Japão.

Em meados da década de 1980, Sasaki (2004) relata as primeiras notícias dos filhos e netos de japoneses que moravam no Brasil e saíram para a "Terra do Sol Nascente", ou seja, os dekasseguis que chegaram ao Japão como trabalhadores temporários. Não tiveram problemas burocráticos, já que muitos tinham dupla nacionalidade. Como ressalta Sasaki (2004), o fenômeno dekassegui, nessa época, era caracterizado como "movimento tímido em termos de volume". Nesse mesmo período, o Brasil vivia uma intensa recessão econômica, marcada pela inflação e pelo desemprego no país, ao passo que no Japão os mais jovens buscavam empregos promissores, que não eram aqueles oferecidos pelas pequenas e médias empresas. Tudo 
isso se agravava com o baixo índice de natalidade dos japoneses e, consequentemente, com o envelhecimento da população e a queda na força de trabalho. Em decorrência da falta de mão de obra japonesa, muitas empresas faliram, tendo que recorrer a trabalhadores estrangeiros. Entre 1986 e 1991, o Japão vivia uma boa situação econômica, atraindo muito trabalhadores estrangeiros, inclusive muitos ilegais, e a maioria era proveniente de países asiáticos.

Segundo Yamanka e Komai (1996, 1990 apud Sasaki, 2004), o Japão foi substituindo os trabalhadores ilegais por trabalhadores descendentes de japoneses, dando ênfase à consanguinidade, com o aval para exercer as atividades no Japão, por tempo indeterminado, $e$ podendo residir permanentemente no país.

A política de imigração favorável aos "latinos-americanos" [sic] de origem japonesa é vista pelas autoridades japonesas como um meio de baixo custo político para ajudar a resolver a falta de mão de obra, com a vantagem adicional de que os imigrantes de ancestralidade japonesa não perturbariam a homogeneidade étnica mítica do país. (Cornelius, 1995, p.396 apud Sasaki, 2004, p.212)

Em virtude da descendência japonesa, os dekasseguis foram aceitos no Japão, uma vez que o parentesco facilitaria a sua adaptação no país, sem questionar a nacionalidade.

Para Miura (2004), o fluxo migratório dos descendentes para o Japão, como país de destino, tem a peculiaridade do encontro com as suas origens étnicas e novos significados daquilo que era passado pelos pais e avós.

Ocada (2002), em sua dissertação de mestrado intitulada Nos subterrâneos do modelo japonês, menciona a figura dos $3 \mathrm{Ks}-\mathrm{Kitanai}^{7}$ (sujo), Kiken ${ }^{8}$ (perigoso) e Kitsui ${ }^{9}$ (pesado) - utilizada para caracterizar o tipo de trabalho destinado aos estrangeiros, e pergunta pelas

7 Kitanai: [adj] sujo (Ohno, 1989, p.368).

8 Kiken: [s, adj-v] perigo, risco, perigoso (Ohno, 1989, p.355).

9 Kitsui: apertado(a), duro(a), pesado(a), áspero(a), severo(a) (Hinata, 1998, p.219). 
razões que levam o migrante dekassegui a partir para o Japão e se submeter a tais condições de trabalho desqualificado. A conclusão da sua pesquisa foi que os entrevistados buscavam altos salários e trabalhos temporários.

Kawamura (2001 apud Sasaki, 2004, p.219) apresenta "os 5 Ks: Kitanai (sujo), Kiken (perigoso), Kitsui (pesado), Kibishii ${ }^{10}$ (exigente) e Kirai ${ }^{11}$ (detestável)", características correspondentes a postos de trabalhos de baixa qualificação, corroborando o significado pejorativo do termo dekassegui.

Galimbertti (2002) retrata as dificuldades e os sofrimentos emocionais daqueles que se aventuraram a deixar o solo natal e buscaram outro lugar distante para trabalhar. Nessa perspectiva, Cibele Cristina Osawa (2006) aponta um trabalho de resenhas críticas bibliográficas sobre "Trabalho 'porco, perigoso e pesado' dos dekasseguis e incidência de doenças psíquicas" do livro de Galimbertti (2002), O caminho que o dekassegui sonhou (Dekassegui no yumê-ji): cultura e subjetividade no movimento dekassegui, em que se depara com relatos de sofrimentos emocionais dos dekasseguis logo no primeiro contato da consulta psiquiátrica. Diante das queixas apresentadas pelos dekasseguis ao médico, são diagnosticados vários transtornos psiquiátricos nessa população de retorno (Osawa, 2006).

Conforme Sasaki (2004), no período dos anos 1980, logo no início do movimento dekassegui, os descendentes de japoneses que saíam do Brasil para trabalhar no Japão não eram bem-vistos. Como nomeia Sasaki (2004), era "um mal necessário", havia uma imagem negativa daquele indivíduo que deixava o seu país de origem. No entanto, o Japão precisava de mão de obra não qualificada e barata, ou seja, de imigrantes que fizessem o trabalho sujo, perigoso e penoso que os japoneses se recusavam a fazer. Com o passar do tempo, foi se construindo uma imagem mais positiva do trabalhador dekassegui entre os nikkeis, ${ }^{12}$ ligando-o à ideia de ancestralidade,

10 Kibishii: [adj] severo, rigoroso; intenso (Ohno, 1989, p.349).

11 Kirai: [adj-v] desgosto, antipatia, aversão, ódio (Ohno, 1989, p.360).

12 Nikkei: [Nikkei no] de origem japonesa (Hinata, 1998, p.315). 
consanguinidade e de busca pelo conhecimento da cultura japonesa e de aproximação das suas raízes.

Yamanaka (1996 apud Sasaki, 2004, p.221) classifica esse movimento dos descendentes de japoneses como uma "migração de retorno". Para conseguir trabalhar no Japão, o requisito exigido é ser de origem japonesa, os chamados nikkei-jin, ${ }^{13}$ ou estrangeiros. Kawamura (2008), em seu texto Brasileiros no Japão: direitos e cidadania, associa o termo nikkei aos japoneses e descendentes que moram fora do Japão.

Podemos dizer que os descendentes de japoneses, ao irem ao Japão, estão repetindo o mesmo trajeto dos seus pais e avós, numa forma de elaboração?

13 Nikkei-jin: pessoa (f) de origem japonesa (Hinata, 1998, p.315). 


\section{2. \\ TRANSNACIONALISMO}

\section{Conceito de transnacionalismo}

As migrações contemporâneas têm sido alvo de interesse dos estudiosos em razão da frequência e da rapidez com que esses deslocamentos migratórios têm ocorrido na atualidade. Esses fluxos migratórios têm alterado o comportamento étnico, modificando a forma de ser das pessoas, influenciando as políticas econômicas e envolvendo questões religiosas, culturais e sociais de todos os países. Essa mobilidade espacial tem traçado novos destinos e formado novos grupos sociais. Esses deslocamentos sempre fizeram parte da história da humanidade, mas vêm trazendo novos sentidos para as ciências contemporâneas. Em sua obra Nuevos retos del transnacionalismo en el estudio de las migraciones, Solé, Parella e Cavalcanti (2008, p.13) assinalam que as antigas migrações são distintas das contemporâneas:

Una de las imágenes más frecuentes y arraigadas sobre la inmigración responde a las primeras etapas históricas de los movimientos migratorios, en las que se asume que los migrantes llegan a otro país para quedarse y pierden progresivamente los vínculos con su país de origen. Pero estas concepciones binarias ya no son válidas a la hora de captar 
las actuales migraciones internacionales en su complejidad. En la actualidad, los inmigrantes desarrollan redes, actividades, estilos de vida e ideologías que engloban a la vez las sociedades de origen y de destino.

Nesse novo cenário migratório, o imigrante mantém o vínculo com o seu país de origem, que ultrapassa as fronteiras. Assim, Solé, Parella e Cavalcanti (2008, p.13) apontam que "este hecho permite hacer emerger nuevos perfiles de inmigrantes y requiere nuevas conceptualizaciones". Esse novo perfil que surge na população imigrante é o que podemos nomear transnacionalismo? O que é transnacionalismo?

Definimos transnacionalismo como los procesos através de los cuales los inmigrantes construyen campos sociales que conectan su país de origen y su país de asentamiento. Los inmigrantes que construyen campos sociales son designados «transmigrantes». Los transmigrantes desarrollan y mantienen múltiples relaciones - familiares, económicas, sociales, organizacionales, religiosas, políticas - que sobrepasan fronteras. Los transmigrantes actúan, toman decisiones y se sienten implicados, $y$ desarrollan identidades dentro de redes sociales que les conectan a ellos con dos o más sociedades de forma simultánea. (Glick Schiller; Bach; Szanton Blanc, 1992 apud Solé; Parella; Cavalcanti, 2008, p.15)

De acordo com Solé, Parella e Cavalcanti (2008, p.14), "No todos los migrantes necesariamente se ven imbricados en prácticas sociales de carácter transnacional". Porém, isso nos mostra que nem todos os imigrantes são transnacionais, mas, em decorrência do desenvolvimento de novas tecnologias, que é considerado um grande marco nas ciências contemporâneas, aceleravam-se os meios de comunicação e de transporte, facilitando e interligando a vida de quem mora do outro lado do mundo. Essas interconexões, o acesso fácil à internet e a transmissão das imagens em tempo real para qualquer lugar do mundo têm possibilitado a participação do imigrante na vida familiar, social e até nos seus negócios fora do país de destino. A velocidade das comunicações e o tempo estão juntamente arraigados, 
promovendo o desaparecimento da distância geográfica, ultrapassando as nacionalidades e construindo várias e novas formas de espaços sociais. O vínculo estabelecido pelos imigrantes é de extrema importância para o funcionamento das redes sociais na atualidade e produz uma série de efeitos globais.

Através de dichas prácticas transnacionales se superan las aproximaciones teóricas convencionales que conciben las migraciones desde planteamientos unidireccionales, basadas en la errónea premisa de que los inmigrantes y sus descendientes rompen necesariamente sus relaciones y vínculos con la sociedad de origen. (Solé; Parella; Cavalcanti, 2008, p.13)

O imigrante transnacional não costuma romper as relações sociais com o seu país de origem. Portanto, podemos dizer que o imigrante contemporâneo é sinônimo de transnacionalidade? O conceito de imigrante transnacional, segundo Solé, Parella e Cavalcanti (2008, p.14) é diferente do conceito de imigrante internacional, transfronteiriço e multinacional: "[...] puesto que si fuera así se trataría de un concepto redundante, sin capacidad heurística y analítica”. Os autores ainda salientam que o transnacionalismo pode ser entendido como "[...] el establecimiento de vínculos de naturaleza diversa entre el lugar de origen o de referencia y el lugar de establecimiento o de llegada" (Solé; Parella; Cavalcanti, 2008, p.14). Então, podemos inferir que o imigrante transnacional é aquele indivíduo que se mantém vinculado ao seu país de origem e ao país de destino.

$\mathrm{O}$ vínculo que os imigrantes estabelecem com o seu lugar de destino e com o lugar de origem determina o marco que distingue as velhas e as novas migrações, sem esquecer também que essas migrações transnacionais formam novas identidades ligadas ao capitalismo global e ao trabalho.

Diante de uma economia globalizada, são inúmeros os motivos que levam os emigrantes a saírem do seu país de origem. A esse respeito, Solé, Parella e Cavalcanti (2008) apontam que as causas das migrações já estão definidas pelos emigrantes quando se deslocam 
para o país de destino. O emigrante, quando parte, parte de algum lugar concreto e chega também a outro lugar concreto, ou seja, existe um lugar de origem e um lugar de destino. Muitos desses emigrantes permanecem no lugar de destino e outros acabam retornando ao país de origem.

Alguns estudiosos discutem a analogia dos termos global e local fazendo referência à globalização. Roland Robertson (1994 apud Schiller, 2008, p.26) menciona, de forma comparativa, "[...] la idea de que lo local y lo global son ámbitos que se construyen el uno con ayuda del otro".

[...] sólo un enfoque comparativo puede darnos una idea aproximada de qué procesos de la dinámica global-local son propios de un sitio y vienen determinados por la historia local y cuáles se hallan estructurados de un modo más amplio, haciendo que la penetración de lo global provoque como resultado que los lugares se hagan similares entre sí en determinados aspectos. (Tilly, 1983; Fox, 2002; Norface, 2008 apud Schiller, 2008, p.26)

No final da década de 1980, Schiller (2008), juntamente com outros estudiosos, tem lutado para que as pesquisas científicas migratórias não fiquem somente dentro de um território Estado-nação e que possam transcorrer além dos paradigmas geográficos, uma vez que suas vidas transmigram a ambos os lados das fronteiras. Por esta razão, o autor define o nacionalismo metodológico como uma tendência intelectual, subdividindo-o em três itens, a saber: "(1) da por hecho que la unidad de estudio y la unidad de análisis vienen definidos por las fronteras nacionales, (2) identifica sociedad con Estado-nación, y (3) combina los intereses nacionales con la finalidad y las materias clave de la ciencia social"' (Schiller, 2008, p.27).

Para Schiller, Beck e Wimmer (apud Schiller, 2008), o nacionalismo metodológico tem sido de grande importância para a ciência social ocidental, abrangendo questões importantes nas principais correntes de estudos migratórios e visando explicar a integração, a inclusão e a exclusão. $\mathrm{O}$ nacionalismo metodológico interpreta, 
através da história e da sociedade, os processos migratórios com base em suposições que relacionam entre si. Portanto, isso acaba limitando a visão sobre o desenvolvimento transnacional e suas consequências nos fatores econômicos, sociais e intelectuais, e mostra dados que não condizem com a realidade dos lugares.

Schiller (2008, p.27) salienta que "el nacionalismo metodológico establece una estructura lógica que presenta a los inmigrantes como la principal fuerza diferenciadora que amenaza el tejido social de la nación". De acordo com essa citação, os imigrantes representam a diferença cultural, compartilhando do mesmo Estado-nação, e devem ser semelhantes ao grupo. O autor acrescenta, ainda, que "Así, el estudio de la interacción entre los nativos y las personas de origen inmigrante o de otras nacionalidades se enfoca bajo la premisa de que la diferencia étnica es un factor esencial en la formación de las relaciones entre ellos" (Schiller, 2008, p.27).

Com o nacionalismo metodológico delimitando o Estado-nação como unidade de estudo, lança-se a ideia de um mundo fundamentado na mesma origem, e os emigrantes que partem do mesmo Estado-nação são semelhantes do ponto de vista cultural e religioso. Esses emigrantes que se relacionam entre si e que pertencem ao mesmo Estado-nação são definidos como "comunidades étnicas o minoritarias" (Schiller, 2008, p.28).

O nacionalismo metodológico também se torna importante a partir dos estudos das localidades específicas nos meios migratórios. Limitado na visão da influência dos imigrantes como Estado-nação, não consegue visualizar o "papel transformador de éstos en la reestructuración y el reescalamiento de las localidades" (Schiller, 2008, p.28).

Nessa perspectiva, Schiller (2008) menciona que dificilmente os estudiosos de migrações contemporâneas relacionam as imigrações e as localidades como objetos de estudos teóricos e não apontam como esses imigrantes constroem essas conexões com os lugares específicos e contribuem na transformação desse espaço de acolhimento.

Antigamente, os deslocamentos migratórios eram centralizados na perspectiva nacional. Conforme Cinel (1990 apud Schiller, 2008, p.28), "se habla de los italianos, los irlandeses o los chinos - no 
se trataba de migraciones nacionales, sino del traslado de personas provenientes de unas regiones y lugares específicos". Além disso, esses imigrantes não se fixavam em todo território de um país.

Schiller (2008) explica que alguns pesquisadores da migração transnacional conseguiram escapar das consequências do nacionalismo metodológico e outros não, mostrando em suas pesquisas os efeitos globais da reestruturação de capital, no entanto, sem identificar o tempo e o espaço dessas transformações correlacionadas. Logo, o paradigma transnacional pode ser visto por meio da história e da geografia. Nesse sentido, Harvey (1973, p.13-4 apud Schiller, 2008, p.29) salienta que:

Charles Wright Mills entendía tal reflexividad como la aplicación práctica de la imaginación sociológica, mediante la cual «el individuo sólo puede entender su propia experiencia [...] situándose él mismo dentro del periodo [...] La imaginación sociológica nos permite captar los factores históricos y biográficos y las relaciones entre ambas dentro de la sociedad» (1959:5). El geógrafo David Harvey (1973:24) ha apuntado que existe también una «imaginación geográfica», o conciencia espacial, que nos permite «reconocer cómo las transacciones entre individuos y organizaciones se hallan afectadas por el espacio físico que las separa». Debo indicar, no obstante, que para Harvey y muchos otros geógrafos contemporáneos ni el tiempo ni el lugar son conceptos invariables, sino que más bien «las distintas costumbres humanas crean y hacen uso de diferentes conceptos de espacio: el absoluto, el relativo y el relacional».

Os imigrantes surgiram de todos os lugares do globo terrestre. Schiller (2008) explica que foi a partir do século XIX e início do século XX que esses imigrantes forjaram os sistemas econômicos do continente americano e estabeleceram redes transnacionais, promovendo o estabelecimento de vínculos familiares, culturais, econômicos, sociais, religiosos e políticos. Portanto, o termo transnacionalismo passou a ser reconhecido pela importância dessas conexões. Entretanto, os fluxos migratórios diminuíram no período entre a Grande Depressão e a Segunda Guerra Mundial, e passaram 
a ser rotulados, vistos como pessoas maltrapilhas e que deveriam se desligar definitivamente de suas origens, acionando as teorias e políticas assimilacionistas (Schiller, 2008, p.30).

Porém, foi na década de 1990 que o paradigma da migração transnacional se tornou popular, em razão das discussões sobre a globalização. Até então, ainda não eram mencionados os efeitos das novas tecnologias e enfatizava-se somente a importância da formação e acumulação de capital, própria do neoliberalismo. Em 1970, destaca-se a importância do câmbio dado à economia mundial, que favoreceu os movimentos globais de capital e mão de obra. No ano seguinte, com o fim dos acordos de Breton Woods, Schiller (2008, p.30) aponta "[...] el abandono del patrón oro y la decisión de las instituciones financieras de permitir la libre fluctuación de divisas dentro de un mercado abierto [...]”, ou seja, "[...] nuevas vías de formación de capital mediante la reorganización de la relación entre producción $y$ territorio".

Schiller (2008, p.31) considera o neoliberalismo como:

[...] una serie de proyectos contemporáneos de acumulación de capital que modifican la estructura de las relaciones sociales de producción, lo que incluye cambios en la organización del trabajo, el espacio, las instituciones del Estado, el poder militar, la administración, la ciudadanía y la soberanía. Esta reestructuración neoliberal comprende la reducción de servicios y ayudas estatales, la aplicación de fondos y recursos públicos al desarrollo de industrias privadas orientadas a la prestación de servicios que abarcan desde la sanidad hasta la vivienda (a veces por medio de acuerdos que reciben el nombre de asociaciones público-privadas), y el incesante impulso de la producción global a través de la supresión de la intervención del Estado en gran número de cuestiones económicas, desde los aranceles a los derechos de los trabajadores.

No final da década de 1980, muitos pesquisadores começaram a mostrar interesse pelas migrações transnacionais. Nesse mesmo período, muitas indústrias tornaram-se multinacionais. Entre os anos de 1987 e 2000, novamente surgem as teorias transnacionais, 
movidas pelos câmbios nos processos globais. De acordo com Harvey (1989; 1992 apud Schiller, 2008), estava declarada a era pós-moderna e enfatizava-se uma nova visão de deslocalização dentro das teorias da modernidade. Giddens (1990, p.18 apud Schiller, 2008, p.31) mostra que "[...] el advenimiento de la modernidad fomentaba las 'relaciones entre 'ausentes', geográficamente alejados de cualquier situación de interacción cara a cara".

O rompimento da migração transnacional com o nacionalismo metodológico da imigração, que conservava ainda o interesse dos Estados-nação, desperta novos olhares acerca da discussão sobre o assunto. Schiller (2008, p.32) considera que "[...] dábamos más importancia a las imágenes e ideas de movilidad, desconexión, disyunción y localidad y prestábamos poca atención al concepto de lugar". Harvey (1989 apud Schiller, 2008, p.32) chamava a atenção para o tempo e o espaço:

[...] había popularizado en un extenso ensayo sobre los vínculos entre la reestructuración de capital y la aparición del posmodernismo, para expresar que el lugar por sí mismo había dejado de tener importancia; sin atender a los insistentes llamamientos de Harvey en el sentido de que el capital, al igual que las relaciones sociales, seguí formándose en lugares específicos.

O neoliberalismo proporcionou aos pesquisadores tanto uma melhor compreensão da migração transnacional como a formação de novos conceitos sobre o assunto. Estimulou geógrafos a entender e perceber a concepção transformadora de espaço e lugar, possibilitando uma reestruturação urbana, conceitos de relações de escala e governo. Assim, menciona Schiller (2008), os geógrafos teriam que deixar as teorias preestabelecidas sobre a imigração, não direcionando a geografia ao espaço físico das unidades sociopolíticas de residência.

Schiller (2008) assinala que o espaço e o lugar são conceitos e que todas as localidades contemporâneas estão sincronizadas num processo de globalização, transmudando diante dos programas neoliberais. 
Dentro dos estudos migratórios, podemos destacar a imigração japonesa como inusitada na escala planetária da mobilidade humana. O tempo não apagou os sentimentos dos seus descendentes para com a terra natal dos seus avós. Por mais de um século, desde a partida dos primeiros emigrantes japoneses para o Brasil, em 1908, esses sentimentos vêm se fortificando com a viagem de retorno dos dekasseguis à terra dos seus antepassados em meados da década de 1980, permanecendo um estado de ligação contínua que sobreviveu à falta de tecnologias, à lentidão dos transportes e das comunicações daquela época. $\mathrm{O}$ velho se mistura com o novo, transformando-se num estado uno. A emigração/imigração japonesa representa, no mundo contemporâneo, o que denominamos de transnacionalidade, em virtude da contínua manutenção dos laços afetivos dos imigrantes descendentes de japoneses com o Japão.

O vínculo que é estabelecido e que sempre existiu na população dekassegui, com os parentes ou a própria terra, não se perdeu com a distância geográfica, ou seja, resultou na formação de novos espaços subjetivos e geográficos, construindo uma nova subjetividade de sujeito.

\section{Transnacionalidade e identidade}

O Brasil, num primeiro momento considerado receptor de imigrantes, na década de 1980 vê o processo se inverter quando passa a enviar mão de obra para o exterior. $\mathrm{Na}$ atualidade, deparamo-nos com a volta dos pais dekasseguis e seus filhos para o Brasil. Essas crianças estão fortemente vinculadas às terras de seus bisavós, trazendo um mundo japonês dentro de si. Será possível, então, pensar numa nova construção identitária? Qual é a identidade desse novo sujeito contemporâneo?

Stuart Hall (2005), em seu livro A identidade cultural na pós-modernidade, coloca em discussão as novas identidades contemporâneas dentro de uma visão social. Hall aponta que, durante muito tempo, as velhas identidades na modernidade viram o sujeito como 
um ser unificado. Atualmente, há um desabamento dessas velhas identidades, fragmentando o sujeito pós-moderno e dando origem a novas identidades. Essas desconstruções identitárias contemporâneas compõem o que Hall (2005, p.7) chama de "crise de identidade".

A assim chamada "crise de identidade" é vista como parte de um processo mais amplo de mudança, que está deslocando as estruturas e processos centrais das sociedades modernas e abalando os quadros de referência que davam aos indivíduos uma ancoragem estável no mundo social.

Hall (2005, p.8) afirma que a identidade do sujeito na modernidade está "descentrada". Considera que é um assunto novo e difícil pela sua complexidade, e gera, portanto, amplas discussões para os sociólogos. Além disso, o autor explicita que o conceito de identidade ainda não está definido, pois requer maior compreensão no campo da ciência social.

O sujeito da pós-modernidade está vivendo um processo de mudanças que se iniciou na era moderna, no final do século XX. As transformações que vêm ocorrendo nas sociedades contemporâneas têm alterado as nossas próprias identidades, alerta Hall (2005, p.9), "abalando a ideia que temos de nós próprios como sujeitos integrados" e levando à "perda de um sentido de si estável". Esse processo de mudança acaba alterando as paisagens culturais de classe, gênero, sexualidade, etnia, raça e nacionalidade, modificando a maneira de ser de cada indivíduo no planeta.

Hall (2005) explica que o sujeito contemporâneo passa a não ter uma localização social sólida. O indivíduo perde a sua referência de lugar no mundo social e cultural e de si mesmo. A esse respeito, Mercer (1990, p.43 apud Hall, 2005, p.9) comenta que "a identidade somente se torna uma questão quando está em crise, quando algo que se supõe como fixo, coerente e estável é deslocado pela experiência da dúvida e da incerteza".

Então, podemos dizer que o sujeito pós-moderno surge numa identidade que está em movimento? Para Hall (2005, p.10), o sujeito 
pós-moderno pode ser visto como sujeito "pós", de modo relativo, não pertencente a uma identidade fixa, porém que busca compreender e fundamentar a subjetividade do homem.

Hall (2005) apresenta três concepções de identidade: sujeito do Iluminismo, sujeito sociológico e sujeito pós-moderno. Segundo o autor, essas concepções de identidade são distintas uma das outras.

O sujeito do Iluminismo era o indivíduo como centro de tudo, dono de suas próprias capacidades intelectuais, de consciência e de ação. Portanto, desde o nascimento até a sua morte, ele permaneceria sendo o mesmo sujeito, por toda a sua vida. Hall (2005, p.11) considerava "individualista" essa concepção do sujeito e da sua identidade, já que o próprio sujeito do Iluminismo era falado no gênero masculino. $\mathrm{O}$ eu do sujeito era formado na própria relação de si mesmo.

O sujeito sociológico era formado na relação com o outro. Surge a visão de mundo interno e externo. O homem toma consciência de suas fraquezas e impotência, buscando valores, sentidos para o seu mundo. Mead e Cooley (apud Hall, 2005, p.11), juntamente com os interacionistas simbólicos na sociologia, definiram a "[...] concepção interativa da identidade e do eu". Dessa maneira, dentro da sociologia clássica, entende-se que "[...] a identidade é formada na interação entre o eu e a sociedade" (Mead; Cooley apud Hall, 2005, p.11). Então, o indivíduo nasce com um eu interior que pode ser construído de forma contínua com o mundo exterior.

De acordo com Hall (2005), usamos mecanismos de projeção e internalização para interagir com o mundo externo. De forma automática, colocamos para fora nós mesmos e recebemos de fora para dentro do nosso eu significados que vão construindo parte de nós. Assim, associamos os nossos sentimentos aos lugares que ocupamos geográfica, social e culturalmente. Portanto, a identidade liga o sujeito à estrutura, ajustando, antecipadamente e de forma unificada, o sujeito ao seu mundo cultural.

Enfatiza Hall (2005, p.12) que as coisas estão "mudando". Antes, o sujeito tinha uma identidade estável e unificada. Atualmente, o sujeito está se tornando fragmentado e "senhor" de várias 
identidades. Dessa forma, não se pode contar com uma estrutura externa para assegurar subjetivamente as próprias necessidades, em razão das "mudanças estruturais e institucionais". Surge no sujeito um novo processo de identificação de mundo, que Hall chama de "provisório, variável e problemático".

Esse processo produz o sujeito pós-moderno, conceptualizado como não tendo uma identidade fixa, essencial ou permanente. A identidade torna-se uma "celebração móvel": formada e transformada continuamente em relação às formas pelas quais somos representados ou interpelados nos sistemas culturais que nos rodeiam.

$[\ldots]$

É definida historicamente, e não biologicamente. O sujeito assume identidades diferentes em diferentes momentos, identidades que não são unificadas ao redor de um "eu" coerente. Dentro de nós há identidades contraditórias, empurrando em diferentes direções, de tal modo que nossas identificações estão sendo continuamente deslocadas. Se sentimos que temos uma identidade unificada desde o nascimento até a morte é apenas porque construímos uma cômoda estória sobre nós mesmos ou uma confortadora "narrativa do eu". (Hall, 1990 apud Hall, 2005, p.12-3)

Hall (2005) afirma que não existe uma identidade plena, unificada, segura e coerente, pois, se assim fosse, seria uma fantasia. Os sistemas de significação e representação cultural vêm se multiplicando e nos desestabilizando, e compõem diversas identidades com as quais poderíamos nos identificar momentaneamente.

\section{Identidade híbrida}

No texto "Sendo índio em português", do livro Língua(gem) e identidade, Tereza Machado Maher (1998, p.120) mostra o desejo dos professores índios de aprender a língua tradicional do seu povo para ensiná-la aos alunos: 
Esta vontade (de aprender Shawãdawa) vem porque além de ser a nossa língua de minha comunidade, ela é nossa língua própria mesmo... Eu falo, eu estou falando aqui em português: a cara, a língua, a boca tudo é minha, agora a fala não é minha porque é emprestada... (após uma pequena pausa, sorrindo) Num é ée, né?... vai e vem... é, e num é.

Podemos notar, nesse discurso, que o professor índio, ao mencionar a língua portuguesa, diz que a sua fala está sendo "emprestada", desconsiderando a língua portuguesa como língua nativa.

Qual é a língua nativa de Eiko, que nasceu no Japão e foi educada na língua japonesa? E quanto à língua de Letícia, que nasceu no Brasil e migrou para o Japão antes de completar um ano de idade, tendo a mesma formação educacional de sua irmã Eiko? E quanto ao menino Goro, brasileiro nato que partiu para o Japão com quase 2 anos de idade e teve educação similar à de suas primas? Qual será a língua emprestada dessas crianças? Podemos pensar numa identidade híbrida?

O que é uma identidade híbrida?

Podemos pensar que um indivíduo pode ter várias identidades ao mesmo tempo, na pós-modernidade?

O espaço geográfico tornou-se pequeno para o homem. É permitido então dizer que o sujeito não está mais cabendo em seu próprio mundo? Diante de tudo isso, surge um novo sujeito e novas formas de construção da subjetividade humana. $\mathrm{O}$ mundo tornou-se pequeno para o homem; quando não mais foi possível dosar medidas, como no passado, e dispor de um mundo mais controlável e estável, foi necessário ultrapassar barreiras geográficas e criar novos espaços. Nesse desconhecido e novo mundo, a velocidade e o tempo transportam informações, produzindo comunicações numa rapidez incalculável a qualquer lugar do planeta. Com todo esse desenvolvimento tecnológico, o mundo passou a viver a era da insegurança, da instabilidade, da mobilidade física e espacial do sujeito, influenciando, portanto, na formação identitária do homem.

Quando falamos em mudança na modernidade tardia, podemos pensar em globalização? A globalização está produzindo identidades 
híbridas? Hall (2005) relaciona a identidade ao caráter de mudança na modernidade tardia. E caracteriza esse processo de mudança como globalização e produção de identidades culturais. Para o autor, as sociedades modernas estão constantemente em mudanças rápidas e contínuas, o que as distingue das sociedades tradicionais.

É o permanente revolucionar da produção, o abalar ininterrupto de todas as condições sociais, e incerteza e os movimentos eternos... Todas as relações fixas e congeladas, com o seu cortejo de vetustas representações e concepções, são dissolvidas, todas as relações recém-formadas envelhecem antes de poderem ossificar-se. Tudo que é sólido se desmancha no ar [...] (Marx; Engels, 1973, p.70 apud Hall, 2005, p.14)

Anthony Giddens (1990 apud Hall, 2005) salienta que as sociedades tradicionais acreditam que a cultura passada e as experiências geracionais, aliadas ao tempo e ao espaço, preservam o sentido de continuidade do passado, presente e futuro, nas formas de práticas sociais. Também menciona que as formas de práticas sociais estão em constante modificação pelas informações recebidas e alteram seu caráter.

Hall (2005) define o hibridismo como uma mistura entre distintas tradições culturais e novas formas de construções culturais na modernidade tardia. Essa modernidade tardia é conhecida pelo nome de globalização.

Naputano, em sua tese de mestrado Identidades culturais em imigrantes de segunda geração: os filhos de Pedrinhas, afirma que o hibridismo não é a soma de culturas distintas, porém o considera um processo de formações culturais. Para Naputano (2012, p.108), "a cultura é sempre híbrida no sentido de ter uma perspectiva de construção histórica datada e de tensões político-sociais em sua formação".

Assim, híbrido não é uma soma e sim o próprio processo dos elementos que constituem a formação cultural, em outras palavras, a 
ideia de hibridismo é relacionada ao processo de encontro e de produção de novas matrizes de identificação que não são estritamente relacionadas a um resultado matemático da soma entre culturas/ pertencimentos diversos.

\section{Partir e retornar: experiências básicas do imigrante}

Na psicanálise, Freud (1911-1913/1996, p.165-6), em seu texto "Recordar, repetir e elaborar (Novas recomendações sobre a técnica da psicanálise II)", argumenta que "o paciente não recorda coisa alguma do que esqueceu e reprimiu, mas o expressa pela atuação ou atua-o (acts it out)". Em seguida, explica que a compulsão à repetição tem relação com a transferência e com a resistência. Comenta, ainda, que a transferência "é, ela própria, apenas um fragmento da repetição e que a repetição é uma transferência do passado esquecido, não apenas para o médico, mas também para todos os outros aspectos da situação atual” (Freud, 1911-1913/1996, p.166). Freud (1911-1913/1996, p.167) afirma que "o paciente repete em vez de recordar". Assim, o manejo da transferência é de extrema importância para a superação da compulsão à repetição do paciente, podendo desencadear a recordação, a tomada de consciência, libertando-o da resistência.

Lembramo-nos que Eliade (1972), segundo o qual, na tentativa de abolir o tempo, de dominá-lo diante do tormento de passagem e da finitude humana, o homem utiliza da técnica de "voltar atrás" ou de "retornar às origens", ou seja, "para curar-se da obra do tempo é preciso 'voltar atrás' e chegar ao princípio do mundo”. (Higa, 2006, p.34)

Segundo Higa (2006), o "voltar atrás" não é no sentido da cura, mas sim no sentido da elaboração, ou seja, o retorno ao passado é vivenciado como meio de libertação. 
A migração é a reedição dos desafios fundantes da vida e, por isso mesmo, Rouanet (1993) afirma que ninguém mais do que o migrante realiza, de maneira integral, as experiências fundamentais da vida, as experiências básicas da humanidade. O migrante refaz as experiências fundadoras da humanidade, aquelas que permitiram ao homem constituir-se como tal, desbravando o planeta, e refaz também a difícil e delicada experiência ontogenética da grande viagem rumo ao total desconhecido, deflagrada como nascimento. Refaz ao mesmo tempo a experiência filogenética do deslocamento humano pela terra e a experiência ontogenética de exploração pelo recém-nascido. Da mesma forma que, filogeneticamente, o ser humano em suas incursões por regiões desabitadas do planeta explorava e tateava a terra-mãe e o bebê, por sua vez, tateia o mundo para reencontrar a mãe perdida, o migrante também tem que buscar outras paragens para reaver um solo perdido, um solo que abandou ou do qual foi expulso. Ao partir em busca de algo que não conseguiu no lugar de origem, mas que gostaria de tê-lo ali, já engatilha seu retorno, imaginando trazer de volta aquilo que falta e, assim, viver a satisfação de uma vida plena assentada no solo natal. (Justo, 2008, p.108)

O imigrante dekassegui volta à terra dos seus avós, retorna ao passado e às suas origens. Ao nascer, o bebê se desloca do mundo interno, representado pelo útero materno e considerado sua casa até o nascimento (o lugar de sua morada), para o mundo externo, ou seja, rumo ao mundo desconhecido.

Diante de novos costumes, as dificuldades dos dekasseguis são várias, tais como as dos recém-nascidos: o idioma japonês, a comida, o ritmo de trabalho, a moradia, a própria adaptação dos filhos, a distância do Brasil e tantos outros fatores. No turbilhão de estranhamentos e dificuldades, diante do choque cultural, é comum surgir o sentimento de desamparo. Segundo Ferreira e Garcia (2002), o dekassegui considera o Brasil a sua casa e o Japão, o lugar de destino por um tempo definido, ainda que possa ser longo.

De acordo com Hashimoto (1995), quando os migrantes chegam a um país desconhecido, surge uma tensão por não saberem qual é 
o seu lugar. Então, aproximam-se uns dos outros com a finalidade de se apoiarem, buscando sentimentos comuns para que possam elaborar as crises que irrompem com frequência. Assim, a força do grupo coopera para atenuar o efeito impactante do mundo novo e do desconhecido, permitindo que a negação da nova realidade possa ser superada.

Destacam Grinberg e Grinberg (1984) que esses deslocamentos migratórios provocam impactos distintos nas diferentes etapas da vida do indivíduo. Os autores ressaltam a importância do fator idade no momento em que ocorre a migração; e diferem a migração infantil do adolescente, do adulto e do idoso, pois essas pessoas, estando em tempos diferentes, a sentem, cada qual, à sua maneira. Consideram, ainda, que a migração infantil apresenta problemas mais complexos do que a do adulto.

Antecipando informações coletadas nas entrevistas que realizamos durante o trabalho de campo desta pesquisa, um de nossos participantes mencionou a questão da adaptação relacionada ao ciclo de vida:

Com certeza! O processo de adaptação no Japão e no Brasil devido à idade. Acho que o processo de adaptação foi mais acentuado. A dificuldade maior foi aqui no Brasil do que no Japão devido à idade. Ela foi com 3 anos e retornou já estava com 10. Então, essa questão de como ela foi muito pequena para lá, a adaptação ficou até mais fácil e aceitação foi bem melhor do que agora. [...]

O retorno é engraçado, assim, a questão da idade realmente pega bastante no processo de adaptação. Nossa filha caçula, melhor, ela foi menorzinha. Ela foi de colo, com 6 meses e voltou agora com 6, 7 anos. O processo de adaptação dela foi mais tranquilo, então essa questão idade pega bastante.

Diante dessas circunstâncias, Grinberg e Grinberg (1984, p.138) argumentam que a criança imigrante tem uma família que a acompanha, podendo amenizar situações traumáticas em comparação ao adulto. Consideram a família uma "capa protetora", aquela que 
serve de continência para a criança, porém sem esquecer que essa mesma família imigrante também está vivendo a experiência da migração e também precisa de um continente.

Le Bon (1855 apud Freud, 1920-1922/1996) afirma que, quando o indivíduo se compõe num grupo psicológico, qualquer diferença que esse tenha fica submergida, irrompendo uma mente coletiva. Seus pensamentos, seus sentimentos e ações passam a ser grupais.

Le Bon pensa que os dotes particulares dos indivíduos se apagam num grupo e que, dessa maneira, sua distintividade se desvanece. O inconsciente racial emerge; o que é heterogêneo submerge no que é homogêneo. [...] tais dessemelhanças [são] removida[s], e as funções inconscientes, que são semelhantes em todos, ficam expostas à vista. (Le Bon, 1855 apud Freud, 1920-1922/1996, p.85)

Os imigrantes agem psicologicamente como as massas diluídas num inconsciente comum. Apegam-se aos conterrâneos como forma de provimento de segurança e proteção.

Segundo Hashimoto (1995, p.103), o trabalho também aparece como mecanismo de ajuda para a elaboração da separação e proteção do ego. Surge então "a necessidade de trabalhar, trabalhar para esquecer a dor nas atividades árduas e transformá-la em uma sensação boa, de produção".

O anseio por trabalhar - socialmente valorizado - proporciona satisfações secundárias. Mas, como a nossa estrutura social aliena o indivíduo do seu trabalho (em função do princípio do desempenho), somos levados a crer que, no fundo desse anseio de trabalhar, existe na verdade uma forma de suicídio velada e vagamente reconhecível. (Caruso, 1986 apud Hashimoto, 1995, p.103)

Os dekasseguis, após algum tempo no Japão, costumam desvalorizar o Brasil comparando-o, por exemplo, ao esgoto do rio Tietê-um lugar de dejetos, poluído de sujeiras. 
A desvalorização do ausente, que significa a negação dos aspectos positivos da terra natal, enquanto busca do seu próprio caminho, é dificultada pela rejeição da terra presente. Apesar da única tentativa de solução do impasse ser a desvalorização, mesmo que agressiva, torna-se difícil a passagem para a idealização do ausente. É a vivência da perda, através do desgaste da imagem ideal, o mecanismo usado para possibilitar o engrandecimento desse ideal perdido, num processo de reparação e de projeção para o passado. (Hashimoto, 1995, p.93)

As dificuldades que os imigrantes têm em se fixar na terra nova aparecem na idealização de retorno. Pensar em voltar é a forma que o ego encontrou para não se desvincular da terra-mãe. A distância da terra-mãe gera conflito com a nova realidade. Na própria partida para outro país surge a negação do tempo. "Viver o tempo na presença do objeto amado é muito diferente de vivê-lo na ausência. Consequentemente, o viver um tempo vivo é diferente de um tempo morto" (Hashimoto, 1995, p.95).

\section{A chegada/retorno do dekassegui ao Brasil}

O Homo viator está na origem do Homo sapiens... Só os homens viajam, pois os animais se limitam a migrar... só os viajantes são inteiramente humanos, pois enquanto os que ficam não se distinguem das plantas, que têm raízes num certo húmus, e dos bichos, que não podem sobreviver fora do ecossistema em que nasceram, os viajantes exercem, em sua plenitude, a prerrogativa máxima da espécie, a de cortar, consciente e voluntariamente, por algum tempo ou para sempre, os vínculos com o país de origem. (Rouanet, 1993 apud Justo, 2008, p.104)

Sasaki (2004) menciona relatos de trabalhadores dekasseguis que apontam muitas dificuldades para retornar ao Brasil, entre as quais a falta de condições financeiras e os baixos salários brasileiros 
comparados aos pagos no Japão. Depois de idas e vindas entre um país e outro, sentem viver entre os dois lugares ao mesmo tempo: Japão e Brasil.

Conforme Sasaki (2004), os descendentes de japoneses vêm ganhando visto de permanência no Japão, comprando sua casa de morada. Porém, muitos se sentem divididos entre os dois países, sem saber qual é o seu lugar.

Sasaki (2004) mostra que a realidade japonesa atual é muito diferente das lembranças contadas pelos avós imigrantes. Essa imagem do Japão do passado permanece uma cena congelada, na qual a noção temporal se perde nos anos de trabalho árduo. Os migrantes sentem saudades daquilo que ficou em suas lembranças, preservado como sentimento de pertencimento.

Lembra Hashimoto (1995) que o migrante, depois de algum tempo longe da terra-natal, consegue perceber a diferença do que é idealizado e real. Assim, essa desilusão leva o processo de luto a se concretizar com o processo de diferenciação. $\mathrm{O}$ migrante passa a perceber a nova terra e começa a se separar da terra-mãe. No entanto, tal separação não implica o esquecimento total, senão o ego sucumbiria.

Na separação, a pessoa deve desligar-se da imagem idealizada do ausente e procurar substituí-la por outros ideais. Além disso, precisa continuar desenvolvendo as suas atividades normais para possibilitar a continuidade do ego. A separação consiste, portanto, na tentativa de vencer os sentimentos de ambivalência entre a lembrança idealizada e o frágil compromisso com o objeto atual. A forma mais adequada de solucionar tais conflitos é lançar mão de defesas. São esses mecanismos que vão possibilitar o desenvolvimento e adaptação à situação nova [...] e controlar essa ambivalência. (Hashimoto, 1995, p 96)

Justo (2008) corrobora que o desejo de retornar ao país de origem se mantém vivo e forte no imigrante. Esse retorno não difere de outras experiências de voltar ao lugar de origem, para o lugar que 
se conhece, marcado pela história de sua infância presente em suas memórias do passado.

Como se sabe, ocorre aí um temor maior do que aquele que assalta o viajante ao aventurar-se pelo desconhecido. Enquanto o viajante teme o que não conhece, aquele que retorna teme o que já conheceu, teme não reencontrar o que foi deixado ali, aquelas imagens fortemente registradas na memória. É como se uma parte do sujeito, de repente, desaparecesse, morresse, deixasse de existir. Como se ele sofresse uma amputação, um corte com sua origem e não conseguisse mais reconhecer suas filiações primárias; como se os marcos de sua origem tivessem sido removidos e ele ficasse à deriva, sem ancoradouros. (Justo, 2008, p.110)

Segundo Justo (2008, p.110), o partir e o retornar estão intrinsecamente relacionados. $\mathrm{O}$ autor cita o exemplo do viajante que, na despedida, já manifesta o desejo de voltar. Portanto, despedir-se dizendo "até a volta", "volte sempre" ou "volte logo" faz parte do vocabulário do cotidiano alimentado pela ânsia do retorno.

A miragem do retorno não acompanha apenas viajantes e imigrantes. Freud (1926) chegou a atribuir o movimento do retorno a uma tendência geral do funcionamento psicológico. Segundo ele, o organismo tende a restabelecer um estado de equilíbrio anterior perdido. O objetivo do psiquismo seria, na sua base mais elementar, retornar a um estado anterior de ausência de qualquer estimulação ou de qualquer perturbação da quietude do gozo absoluto. O objetivo maior da vida seria o retorno ao estado inanimado. A impossibilidade de manutenção de um estado nirvânico é que poria o aparelho psíquico em funcionamento, no entanto, procurando resgatar o "paraíso perdido”, tarefa essa fadada ao fracasso. (Justo, 2008, p.110)

O imigrante vive a busca pela figura materna que não foi interditada. Espera dar a seus filhos a realização plena dos seus desejos malogrados. Conforme Justo, essa busca do imigrante o levaria a 
retroceder de forma ilusória a um estado anterior de gozo absoluto e de plena felicidade. Quanto mais intenso o desejo pelo objeto, maior a idealização e mais longínqua fica sua realização, tornando o imigrante um ser incansável e desejante. "Por isso mesmo, a realização plena dos desejos dos migrantes está fadada ao fracasso, tornando-os eternos aventureiros em busca de um tesouro perdido" (Justo, 2008, p.111).

Se aquilo que se busca na partida vai se tornando mais distante e inatingível, o mesmo ocorre com o retorno. O que foi deixado para trás também não está mais lá, aguardando a chegada daquele que, um dia, partiu. De fato, o imigrante vive um estranhamento quando retorna ao seu país de origem. Justo (2008) ressalta que esse estranhamento pode ser até maior do que aquele vivenciado no país estrangeiro. O sentimento é de se sentir um estrangeiro em seu próprio país.

A "Readaptação dos dekasseguis no Brasil” foi tema da $4^{\mathrm{a}}$ Reunião Anual da Sociedade Brasileira de Pesquisadores Nikkeis (SBPN), evento marcado pela criação do documento: "Carta de São Carlos - Moção de Apoio aos Trabalhadores Brasileiros na Rota Brasil-Japão". Trata-se de um diagnóstico da situação atual desses trabalhadores, evidenciando as dificuldades enfrentadas principalmente no âmbito dos direitos trabalhistas, na deterioração das condições físicas e psicológicas dos trabalhadores, bem como na dificuldade de readaptação das crianças às escolas brasileiras; apresenta ainda sugestões ao governo brasileiro no sentido de uma maior mobilização para a solução dos problemas. Feita esta análise da situação atual dos dekasseguis no Japão, pode-se dizer que o fenômeno da migração poderá trazer, a médio e longo prazos, consequências para a vida física, social e psíquica do trabalhador. (Miura, 2004, p.196)

Mas não são apenas as condições objetivas, como a readaptação a leis trabalhistas e ao sistema escolar, que representam obstáculos e desafios ao retorno. Existem também os entraves subjetivos que podem, inclusive, ultrapassar os fantasmas emergentes das experiências individuais imediatas e ontogenéticas. 
Justo (2008) considera a imigração uma saga familiar dos dekasseguis. Neste sentido, o imigrante porta heranças familiares que se perdem na sua linhagem, entre elas os legados construídos pelas gerações anteriores, dos quais se apropria, e também as dívidas (conflitos) que recaem sobre ele como fardos que tem de carregar. Assim, o desejo de migrar, de ir para longe em busca do almejado, no caso da imigração de retorno, carrega consigo, inevitavelmente, o desejo de reaver legados dos antepassados deixados na terra natal, como se fossem tesouros soterrados.

Justo ressalta que o retorno dos dekasseguis ao solo natal de seus antepassados pode ser entendido como um movimento psicológico de repetição, uma tentativa de elaboração: "Grosso modo, diríamos que o imigrante vai e volta sempre buscando algo que jamais conquistará, tal como um garimpeiro ou um apostador que acredita numa sorte maior" (Justo, 2008, p.112).

\section{Imigração/nascimento}

Grinberg e Grinberg (1984, p.15) mencionam que o mito do Éden representa o símbolo do nascimento, no qual o bem supera o mal. Os autores o consideram, ainda, como "[...] el símbolo del nacimiento, la primera migración de la historia individual, con la disociación consecutiva al mismo ('supieron del bien y del mal')". As primeiras experiências primitivas de ansiedades paranoides e depressivas são sentidas pela perda do objeto idealizado e desencadeiam a vivência da angústia de desamparo, ficando o bebê com sua própria força. Essas experiências são consideradas migratórias e fazem parte da evolução do homem que se distancia do seu objeto original materno.

"Parir con dolor": el dolor del propio nacimiento; del desprendimiento; $y$ "ganarse el pan con el sudor de la frente": perder el suministro continuo e incondicional del cordón umbilical, tener que buscar el propio alimento (pecho), sufrir por la pérdida de objeto (destete) y esforzarse por su reparación y recuperación. (Grinberg; Grinberg, 1984, p.16) 
Podemos dizer que o nascimento é uma experiência migratória. O bebê se desloca de um mundo bastante protegido para outro mundo no qual terá que se defrontar com experiências de acolhimento, mas também de desamparo. $\mathrm{O}$ feto deixa a barriga da mãe para renascer numa outra condição, abandonando a total dependência, caminhando para a chegada a um mundo diferente e desconhecido, tendo que lidar com a dor da separação e com o processo de adaptação. $\mathrm{O}$ feto, ao se deslocar para fora, passa a ser representado pela figura de um bebê, trazendo formas primitivas e rudimentares de comunicação. Há uma mudança fundamental logo ao nascer: o feto sai de uma condição passiva e passa para uma condição relativamente ativa no seu novo ambiente.

À semelhança do recém-nascido, o imigrante não sai propriamente de uma situação inteiramente passiva, mas abandona uma situação de relativa segurança e familiaridade para enfrentar o desconhecido, um outro mundo.

La inmigración, justamente, no es una experiencia traumática aislada, que se manifiesta en el momento de la partida-separación del lugar de origen, o en el de llegada al sitio nuevo, desconocido, donde se radicará el individuo. Incluye, por el contrario, una constelación de factores determinantes de ansiedad y de pena. (Grinberg; Grinberg, 1984, p.23)

Grinberg e Grinberg (1984), em sua análise, ponderam que o imigrante poderá ou não viver como um trauma a experiência de deixar o solo natal e buscar outro país - isso dependerá da sua constituição psíquica e do conjunto de suas vivências dadas no momento da imigração.

O período inicial de adaptação do imigrante pode ser considerado um período de latência, porque nele são mobilizados os traumas acumulados e os chamados "duelos postergados".

A esse respeito, Grinberg e Grinberg (1984, p.4) salientam que a experiência traumática poderia ser categorizada por "traumatismos acumulativos y de tensión"; embora suas reações nem sempre sejam ruins e aparentes, os seus efeitos serão profundos e duradouros. 
Os traumas ressuscitados na experiência do imigrante podem ser comparados com os da adolescência ou entendidos como uma crise evolutiva. Nas crises de desenvolvimento há momentos de privações e perdas, como ocorre no nascimento e em todas as fases da vida. Essas transições são sentidas como perigos, como aumento da vulnerabilidade e de doenças psíquicas. Winnicott (1971 apud Grinberg; Grinberg, 1984) sustenta que a herança cultural assegura a continuidade do homem em suas crises ou rupturas. Grinberg e Grinberg (1984), porém, acreditam que, quando ocorrem rupturas, a herança cultural não consegue assegurar sozinha a sua continuidade, tal como pode acontecer com os migrantes que passam a viver em outro lugar.

Winnicott considera "la herencia cultural" como una extensión del "espacio potencial" entre el individuo y su ambiente. El uso del "espacio potencial" está, pues, supeditado a la formación de un "espacio entre dos", entre el yo y el no-yo, entre el "adentro" (grupo de pertenencia) y el "afuera" (grupo de recepción), entre el pasado y el porvenir. (Grinberg; Grinberg, 1984, p.25-6)

El inmigrante necesita un "potencial" que le sirva de "lugar de transición" y "tiempo de transición", entre el país-objeto materno, y el nuevo mundo externo; "espacio potencial" que otorgue la posibilidad de vivir la migración como "juego", con toda la seriedad e implicaciones que este tiene para los niños. (Grinberg; Grinberg, 1984, p.26)

Ao fracassar a criatividade, nesse espaço potencial, é produzida a ruptura na continuidade do "entorno y del self". De acordo com Grinberg e Grinberg (1984), a ruptura que ocorre no sujeito é sentida como longas ausências do objeto cuidador. A criança perde a capacidade de simbolização e faz uso de defesas primitivas arcaicas.

Então, a migração é um estado de desorganização que, posteriormente, pode ou não se reorganizar. Essa desintegração considerada transitória é ocasionada pelas angústias que irrompem em situações de estresse. Trata-se de uma experiência marcada por agitações e 
tormentos, na qual o migrante caminha entre as tempestades na transição de um momento de vida a outro, tal como acontece com o adolescente na passagem da infância para a vida adulta. Os migrantes, à semelhança dos adolescentes, deixam o mundo velho infantil para chegar ao mundo novo e desconhecido. Levará muito tempo até chegarem à terra firme, na qual poderão se sentir realmente seguros num novo mundo. 


\section{3. \\ A EXPERIÊNCIA DA SEPARAÇÃO PARA OS IMIGRANTES}

O mundo, hoje, exige maior plasticidade do sujeito quanto às suas referências identitárias e faculta experiências de mobilidade, desenraizamento, nomadismo, desterritorialização e tantas outras que rompem com experiências marcantes de outras épocas quando predominava o sedentarismo. No entanto, o deslocamento de um lugar a outro, de uma cultura a outra, é acompanhado de grandes dilemas, dificuldades e desafios, sobretudo no plano psicológico. A adaptação ao novo lugar, à nova cultura, a um novo país, mobiliza figuras e processos de subjetivação bastante enraizados e básicos no funcionamento psicológico.

Freud (1893-1895/1996) considera que uma das formas de expressão da não adaptação pode se configurar nos sintomas histéricos, trazendo efeitos e resíduos de excitações que atuaram sobre o sistema nervoso como traumas. Na histeria, considera-se que uma parte dessa soma de excitação do trauma é transformada em sintomas puramente somáticos. Outras maneiras de adoecer podem se impor e dependerão do quanto cada indivíduo tenha se desenvolvido emocionalmente.

Uma das ansiedades básicas estruturantes das relações do Eu com o mundo emerge nas primeiras experiências de separação entre o bebê e a mãe, à medida que se instala o reconhecimento, por parte 
do bebê, da existência autônoma e independente de si mesmo e do mundo à sua volta.

Para Quinodoz (1993, p.46):

Os processos de diferenciação e de separação estão estreitamente relacionados com o trabalho de luto, porque aceitar separar-se de outra pessoa implica não só a capacidade de efetuar um trabalho de luto a nível da [sic] relação entre duas pessoas, uma aceitando separar-se da outra, mas também a capacidade de efetuar o trabalho de luto a nível do ego [sic], o que supõe a renúncia à fusão com o objeto do qual se separa, um aceitando diferenciar-se do outro.

Nessa linha de pensamento, Winnicott (1896-1971/2005, p.26-7) assinala que:

O holding tem muita relação com a capacidade da mãe de identificar-se com seu bebê. Um holding satisfatório é uma porção básica de cuidado, só experimentada nas reações a um holding deficiente. O holding deficiente produz extrema aflição na criança, sendo fonte da sensação de despedaçamento, da sensação de estar caindo num poço sem fundo, de um sentimento de que a realidade exterior não pode ser usada para o reconforto interno e de outras ansiedades que são geralmente classificadas como "psicóticas".

Uma das primeiras indagações que surge, diante da importância e da dificuldade da elaboração matricial da separação mãe-bebê, é sobre a mobilização e a eventual irrupção, na experiência dos filhos dos dekasseguis e até mesmo neles próprios, das ansiedades que acompanham vivências ontogenéticas de separação. Então, o abandono do solo natal ressuscita antigas ansiedades depressivas? Outros questionamentos também emergem dessa situação, tais como: as crianças, ainda não inteiramente assentadas na experiência de distanciamento dos pais e de outros objetos com os quais já desenvolveram vínculos emocionais, sofrem com a iminência de uma separação mais acentuada, tanto na realidade como no simbólico? 
O retorno ao Brasil acrescentará outras separações dolorosas com objetos e vínculos, desta vez deixados no Japão? O reencontro com familiares brasileiros e a evocação de outras imagens de amparo e de vinculações anteriores minimizam os efeitos das sobreperdas que ocorrem no retorno?

Por meio da minha própria experiência de vida no Japão, pude constatar que não somente eclodem sentimentos básicos, constitutivos da estrutura e do funcionamento psicológico, como também se desencadeiam crises na articulação da experiência da realidade com conteúdos e estruturas psíquicas consolidadas ou em formação. Tais crises soam como experiências traumáticas diante da dificuldade de assimilar, elaborar e responder adequadamente às estimulações e excitações provenientes de uma realidade estranha e desconhecida.

Segundo Laplanche e Pontalis (2001, p.522), "o termo 'trauma' vem do grego e significa ferida e deriva de furar, designa uma ferida com efração". Os termos trauma e traumatismo são considerados sinônimos na Medicina. O traumatismo define-se como econômico por uma quantidade excessiva de excitações em relação à tolerância do sujeito e à sua capacidade de dominar e elaborar emocionalmente estas excitações. Ocorre de duas formas: positiva, quando o indivíduo se adapta ao novo ambiente e elabora a situação traumática; e na situação oposta, quando não consegue elaborar a situação traumática, em que afloram sentimentos de ansiedade, perigo, chegando a um estado de desamparo e adoecimento.

Freud (1925-1926/1996) definiu inicialmente, em 1894, a ansiedade como a transformação da tensão acumulada. Depois, em "A interpretação dos sonhos" (1900), a ansiedade é considerada um impulso libidinal cuja origem está no inconsciente e é inibida pelo pré-consciente. Freud (1925-1926/1996, p.83), na quarta edição de "Os três ensaios", salienta que a ansiedade neurótica tem origem na libido, que é produto de sua transformação e que se relaciona com ela "da mesma forma que o vinagre com o vinho". Freud não considerava mais a ansiedade como libido transformada, e sim como uma reação específica a situações de perigo. Em 1933, na Conferência XXXII de suas "Novas conferências introdutórias sobre psicanálise 
e outros trabalhos" (Freud, 1932-1936/1996), sugere que também a neurose de angústia surge da ansiedade, uma reação relacionada com a situação traumática. Classifica-a em ansiedade realística, quando o perigo é conhecido; neurótica, quando provocada por um perigo desconhecido; automática, quando o ego não está preparado para tal experiência; e ansiedade de sinal ou de alarme, que corresponde à vivência de um perigo ocorrido anteriormente e que agora se repete de forma atenuada como um sinal de alarme. O que determina a ansiedade automática é a ocorrência de uma situação traumática, e sua essência é uma experiência de desamparo por parte do ego diante de um acúmulo de excitação, seja de origem externa, seja de origem interna, com o qual não consegue lidar. A ansiedade, de sinal ou de alarme, é, então, a resposta do ego à ameaça ou à possibilidade de ocorrência de uma situação traumática.

Freud (1925-1926/1996) esclarece que a ansiedade é algo que se sente, portanto, é um estado afetivo. A ansiedade é resultado de um aumento de excitação, que, por um lado, produz o caráter de desprazer e, por outro, encontra seu alívio por meio dos atos de descarga. Segundo o autor, quando a criança descobre, pela experiência, que um objeto externo perceptível pode pôr termo à situação de perigo, revive o nascimento. Nesse caso, o conteúdo do perigo que ela teme é deslocado da situação econômica para a condição que determinou essa situação, a saber, a perda do objeto. É a ausência da mãe, por exemplo, que agora constitui o perigo, e logo que surge esse perigo a criança dá sinal de ansiedade, antes que a temida situação econômica se estabeleça. Essa mudança constitui a primeira reação de providência adotada pela criança para sua autopreservação e representa, ao mesmo tempo, uma passagem do aparecimento automático e involuntário da ansiedade para a reprodução intencional da ansiedade como sinal de perigo. O fenômeno automático é um sinal de salvação, que considera a ansiedade um produto de desamparo mental da criança, o qual corresponde naturalmente a seu desamparo biológico.

Na realidade, é provável que as primeiras repressões, bem como a maioria das seguintes, sejam motivadas pela ansiedade do ego, no 
tocante a processos do id. Uma situação semelhante ao trauma de nascimento se estabelece no id, seguindo-se uma reação automática de ansiedade. Assim, o perigo psíquico é equivalente ao perigo de vida quando o ego do indivíduo é imaturo. A geração de ansiedade provoca a geração de sintomas em movimento e, na realidade, é um requisito prévio dele, pois se o ego não despertasse a instância de prazer-desprazer, gerando ansiedade, não teria força para paralisar o processo que está preparando no id e que o ameaça com perigo.

Para Rank (apud Freud, 1925-1926/1996, p.147), “o processo de nascimento é a primeira situação de perigo, e a convulsão econômica que ele produz torna-se o protótipo da reação de ansiedade". Conforme Freud (1920-1922/1996), a ansiedade é um estado particular de esperar o perigo ou preparar-se para ele, ainda que possa ser desconhecido. O medo exige um objeto definido de que se tenha temor. Susto, porém, é o nome que se dá ao estado em que alguém fica quando entra em perigo sem estar preparado para ele, dando-se ênfase ao fator surpresa.

Para Freud (1925-1926/1996), o verdadeiro perigo é um perigo conhecido. Nesse caso, a ansiedade é realística. A ansiedade neurótica é a ansiedade provocada por um perigo desconhecido, que tem ainda de ser descoberto. Trata-se de um perigo real pulsional, que leva esse perigo não conhecido do ego até a consciência. Existem duas reações ao perigo real: uma é a reação afetiva, repentina, da ansiedade; a outra é a reação protetora. A análise deve revelar que, além do perigo real conhecido, há um perigo pulsional desconhecido.

Situação de perigo, segundo Freud (1925-1926/1996), consiste no julgamento do paciente diante da própria força, em comparação com a amplitude do perigo e o seu relacionamento de desamparo em face desse perigo: desamparo físico, se o perigo for real; e desamparo psíquico, se for pulsional. Ao proceder assim, o indivíduo se orienta pelas experiências reais que teve. Denominamos essa situação de desamparo de situação traumática.

Freud (1925-1926/1996) ressalta, ainda, que o indivíduo terá alcançado importante progresso em sua capacidade de autopreservação se puder prever e esperar uma situação traumática dessa espécie, 
ou seja, que desencadeia desamparo, em vez de esperar que ela simplesmente aconteça. Na expectativa de uma situação de perigo, o sinal da ansiedade é emitido. A ansiedade, por conseguinte, é uma expectativa de um trauma e também uma repetição dele em forma atenuada. Assim, os dois traços de ansiedade percebidos têm uma origem diferente. Sua ligação com a expectativa pertence à situação de perigo, ao passo que sua indefinição e falta de objeto pertencem à situação traumática de desamparo. Ansiedade-perigo-desamparo (trauma) - presume-se agora que a situação de perigo seja uma situação reconhecida, lembrada e esperada de desamparo. A ansiedade, reação original ao desamparo no trauma, é reproduzida depois da situação de perigo como um sinal em busca de ajuda. O ego, que experimentou o trauma passivamente, agora o repete ativamente, em versão enfraquecida, na esperança de ser ele próprio capaz de dirigir seu curso. A importância decisiva cabe ao primeiro deslocamento da reação de ansiedade de sua origem na situação de desamparo para uma expectativa dessa situação, isto é, para a situação de perigo e, posteriormente, para o determinante do perigo como a perda do objeto e das modificações dessa perda. Isso pode estimular o indivíduo a permanecer no estado de infância, cujo período de vida se caracteriza por desamparo psíquico e motor.

Para Freud (1925-1926/1996), há uma ligação estreita entre a ansiedade e a neurose, visto que o ego se defende contra um perigo pulsional com a ajuda da reação de ansiedade, do mesmo modo que o faz contra um perigo real externo. Frequentemente, uma exigência pulsional torna-se um perigo interno, desde que a satisfação provoque um perigo externo, uma vez que o perigo interno representa um perigo externo. Portanto, o perigo externo (real) deve ser internalizado para ser significativo para o ego. Ele deve ter sido relacionado a certa situação de desamparo já experimentada. À situação traumática, na qual o paciente está desamparado, convergem perigos externos e internos, perigos reais e exigências pulsionais. O desamparo do motor do ego encontra expressão no desamparo psíquico.

Considerando todo esse processo psíquico sobre a teoria do trauma psíquico, neste trabalho pretendemos nos ater à situação 
das crianças que deixam seu país de origem para viver em outro país - neste caso específico, a ida ao Japão - e, depois de um período, retornam a ele para viver em um ambiente modificado pelo tempo, enfrentando adaptações. Esses indivíduos revivem a experiência da separação para se adaptar ou não ao novo ambiente, ou seja, uma experiência traumática de vivência primitiva é atualizada, interferindo no processo de adaptação?

Os indivíduos, quando retornam ao seu país, se veem diante de uma segunda situação de separação e de convívio com um novo ambiente, reagindo de maneiras específicas. Aqueles que conseguem elaborar ou superar experiências traumáticas pregressas terão se desenvolvido para atingir a adaptação à nova situação, mobilizando recursos internos e psíquicos para enfrentar o novo ambiente e as condições que eles mesmos lhes impõem. Porém, aquelas pessoas que passam por experiências traumáticas e que não conseguem enfrentar ou superá-las adequadamente com mecanismos que possibilitem a adaptação recorrem provavelmente a defesas de maneira patológica e adoecem. As manifestações de sintomas - somáticos, afetivos ou comportamentais - estarão presentes em muitos que retornam para o Brasil, e por isso necessitam de acompanhamento psicológico e psiquiátrico. O desamparo mobilizado nessas pessoas pode ser considerado, baseando-se em Freud (1925-1926/1996), semelhante ao vivenciado no trauma do nascimento.

A experiência de se perceber sozinho em um novo ambiente leva o indivíduo a se sentir único e separado. Diante dessas impressões, surgem a dor, o sofrimento da perda e as renúncias, como à própria liberdade, para que possa se adaptar de acordo com as exigências da realidade externa.

Para Winnicott (1975, p.133):

Freud, em sua topografia da mente, não encontrou lugar para a experiência das coisas culturais. Deu um novo valor à realidade psíquica interna e disso proveio um novo valor para coisas que são reais e verdadeiramente externas. Freud utilizou a palavra "sublimação" para apontar o caminho a um lugar em que a experiência cultural é 
significativa, mas talvez não tenha chegado ao ponto de nos dizer em que lugar, na mente, se acha a experiência cultural.

Ele acrescenta que:

O trauma implica que o bebê experimentou uma ruptura na continuidade da vida, de modo que defesas primitivas agora se organizaram contra a repetição da "ansiedade impensável" ou contra o retorno do agudo estado confusional próprio da desintegração da estrutura nascente do ego. (Winnicott, 1975, p.135)

Julgamos ser importante refletir sobre essa questão, pois as crianças que aqui nasceram e migraram com os pais para o Japão passam pela angústia da separação, revivendo o trauma do nascimento, e ao retornarem passam novamente por uma separação, que igualmente gera angústia, levando-as a reviver o trauma do nascimento - apesar do retorno à terra-mãe, considerada o útero materno - para enfrentar novas diversidades em um mundo entre o reconhecido/desconhecido. Redescobrem as sensações de estar só, diante do conhecido. Enfrentam a desconstrução da cultura japonesa internalizada (língua e linguagem, gestos, comportamentos, comida, espaço físico, fantasias, relações objetais etc...) e a reconstrução do novo "eu" em seu próprio país de origem, com sentimentos de impotência e de esperança. 


\section{4. \\ Desamparo psíouico}

\section{Contextualizando o desamparo}

A palavra desamparo foi encontrada nos escritos freudianos em 1895, no "Projeto para uma psicologia científica", no contexto "a experiência de satisfação”. Freud (1886-1889/1996) relata que o recém-nascido precisa de ajuda alheia para promover a ação específica de que necessita para sua sobrevivência. Essa comunicação, que ocorre e que se estabelece entre o bebê e a sua mãe, é de extrema importância para o desenvolvimento emocional do infante. O sentimento de desamparo já é sentido pela criança logo ao nascer.

O desamparo foi adquirindo várias conotações, desde a imaturidade infantil até a necessidade de dependência que o bebê tem de possuir o objeto primário para realizar suas ações específicas. O desamparo, por sua vez, indica em sua essência vivida o sentimento de abandono, que é experimentado na descoberta do eu do indivíduo com o mundo.

A figura materna tem o papel fundamental no desenvolvimento emocional do bebê em relação ao seu mundo interno e externo. A mãe funciona como intérprete de suas ansiedades e medos. Portanto, a mãe usa as informações que são manifestadas pelo bebê e passa a transformá-las, devolvendo-as de forma interpretativa. Assim, uma boa relação e comunicação fazem o bebê se sentir amparado. De 
forma contrária, quando a mãe não consegue perceber a real necessidade do bebê, este pode cair em estado de desamparo psíquico.

Freud (1927-1931/1996), em “O futuro de uma ilusão", destaca que a mãe satisfaz a fome da criança e se torna o primeiro objeto amoroso e fonte de proteção dos perigos externos e ansiedades. Em seguida, a mãe é substituída pelo pai na função de proteção. Porém, a criança admira o pai e também o teme, por causa de sua relação anterior com a mãe.

O homem cresce e percebe que seu destino é permanecer uma eterna criança, que sempre precisará da proteção de poderes superiores. Conforme a figura de um pai, o homem "[...] cria para si os seus deuses a quem teme, a quem procura propiciar e a quem, não obstante, confia sua própria proteção" (Freud, 1927-1931/1996, p.33).

Podemos dizer que o homem cria Deus - e não Deus cria o homem - para se defender do desamparo infantil no adulto, estabelecendo a religião como forma de proteção dos seus próprios instintos e ameaças externas.

Afinal, o que é desamparo psíquico? A não compreensão da língua materna (no caso, a portuguesa) pode desencadear desamparo psíquico no retorno dos filhos de dekasseguis ao Brasil?

Encontramos na Bíblia Sagrada, em São Mateus, versículo 46, a passagem da morte e ressurreição de Jesus Cristo, quando ele clama pelo Pai, implora por Sua proteção e se sente abandonado à própria sorte. O sentimento de desamparo já aparece esboçado nas Escrituras Sagradas.

Desde a hora de sexta, até à hora nona, as trevas envolveram toda a terra. E, cerca da hora nona, Jesus clamou em alta voz: "Elli, Elli, lema sabacthani”. Isto é: "Meu Deus, Meu Deus, porque Me abandonaste". Alguns dos que ali se encontravam disseram ao ouvi-lo: Está a chamar por Ellias [...]. (Biblia Sagrada, 1971-1972, p.1007)

O dicionário de português Mini Aurélio (Ferreira, 2008, p.296) define a palavra desamparo como "falta de amparo e abandono". O Dicionário Enciclopédico Ilustrado Veja Larousse (2006, p.84) o 
explica como uma "condição do que ou de quem está abandonado, sem ajuda material ou moral".

Termo da linguagem comum que na teoria freudiana assume um sentido específico: estado do lactente que, dependendo inteiramente de outrem a satisfação das suas necessidades (sede, fome), se revela impotente para realizar a acção específica adequada para pôr fim à tensão interna. Para o adulto, o estado de desamparo é o protótipo da situação traumática geradora de angústia. (Laplanche; Pontalis, 1970, p.156)

Laplanche e Pontalis (1970, p.157) citam a palavra em alemão "Hilflosigkeit", que requer uma única tradução, e destacam da língua francesa a expressão "état de détresse", que significa estado de desamparo em vez de "détresse" (desamparo) por si só, por se tratar de um dado específico:

[...] a impotência do recém-nascido humano; este é incapaz de empreender uma acção coordenada e eficaz (ver: Acção específica); foi isso que Freud designou pela expressão motorische Hilflosigkeit. Do ponto de vista econômico, tal situação resulta no acréscimo da tensão da necessidade que o aparelho psíquico não pode ainda dominar; é a psychische Hilflosigkeit. (Laplanche; Pontalis, 1970, p.157)

Como podemos notar, o conceito de estado de desamparo foi sendo construído a partir de várias ordens.

No plano genético, Freud (1895), na primeira parte do "Projeto de uma psicologia científica [Entwurf einer Psychologie]", afirma que é a partir dele que se pode compreender o valor princeps da vivência de satisfação, a sua reprodução alucinatória e a diferenciação entre processos primário e secundário.

O estado de desamparo, correlativo à total dependência da criança humana em relação à mãe, implica a onipotência desta. Influencia, de forma decisiva, a estruturação do psiquismo, voltado a constituir-se inteiramente na relação com outrem. 
No quadro de uma teoria da angústia, o estado de desamparo torna-se o protótipo da situação traumática. É assim que em "Inibição, sintoma e angústia” [Hemmung, Symptom und Angst, 1926] Freud reconhece aos "perigos internos" uma característica comum: perda ou separação que acarreta um aumento progressivo da tensão, a ponto de, num caso extremo, o indivíduo se ver incapaz de dominar as excitações e ser submergido por elas - o que define o estado gerador do sentimento de desamparo.

Freud liga explicitamente o estado de desamparo à pré-maturação do ser humano:

a sua $[. .$.$] existência intrauterina parece relativamente abreviada em$ comparação com a da maioria dos animais; ele está menos acabado do que estes quando vem ao mundo. Por este facto, a influência do mundo exterior é reforçada, a diferenciação precoce entre o ego e o id é necessária, a importância dos perigos do mundo exterior é exagerada e o objecto, que é o único que pode proteger contra estes perigos e substituir a vida intrauterina, vê o seu valor enormemente aumentado. Este factor biológico estabelece, pois, as primeiras situações de perigo e cria a necessidade de ser amado, que nunca mais abandonará o homem. (Freud apud Laplanche; Pontalis, 1970, p.157)

Costa (2007) menciona que o termo desamparo aparece nos textos de Freud na discussão sobre os estímulos interiores ou exteriores que afetam o organismo do ser humano. Considera que a resposta adequada a esses estímulos é a "ação específica" motora ou psíquica. Sua função é cessar o estímulo pela satisfação ou pela fuga da situação de sofrimento. Quando isso não ocorre, o estímulo excede a capacidade de resposta. Entretanto, o indivíduo cai em desamparo, podendo desencadear defesas inadequadas, ou seja, psicopatologias.

Em outro texto, o desamparo está associado à ideia de "pré-maturação" do ser humano.

Entre os fatores que contribuem para causar as neuroses, e que criam as condições nas quais as forças psíquicas se medem umas às 
outras, três se destacam particularmente: um fator biológico, um fator filogenético e um fator psicológico. O fator biológico é o estado de desamparo e de dependência muito prolongado do filhote do homem. A existência intrauterina do homem é relativamente breve, em relação à maioria dos animais. Ele é menos acabado que esses últimos, ao ser lançado ao mundo. A influência do mundo exterior real se acha, por isso, reforçada. A diferenciação do eu com isso é adquirida precocemente, os perigos do mundo exterior ganham uma importância maior e, por essa razão, o valor do objeto é aumentado, de modo enorme, pois ele é o único a poder proteger o eu de tais perigos. Assim, o fator biológico está na origem das primeiras situações de perigo e cria a necessidade de ser amado, que jamais abandonará o ser humano. (Freud, 1925-1926/1968 apud Costa, 2007, p.60)

Costa (2007) caracteriza o desamparo, nos dois contextos, como um despreparo do organismo humano para lidar com certos estímulos do meio. Em sequência, Freud distingue o eu e o corpo.

Desamparo do organismo corporal não é a mesma coisa que desamparo de um eu que, em situações de perigo, apela para o objeto e cria "a necessidade de ser amado que jamais abandonará o ser humano". No primeiro uso do termo, desamparo designa estados subjetivos descritos de modo fiscalista. Freud, com ou sem consciência, falava do indivíduo como um organismo físico. Pouco importa se a ideia de "organismo psíquico" ou de "corpo imaginário" estava pressuposta na descrição. O fato é que o desamparo era assimilado ao estado de necessidade reconhecido pelo organismo de forma reflexa e automática. Ao estarmos com fome, apanhamos o alimento desejado por meio da "ação específica"; ao estarmos com sede ou premidos por estímulos sexuais, fazemos o mesmo. (Costa, 2007. p.61)

A expressão "ter necessidade" é conceituada por Costa (2007) na descrição de estados afetivos. $\mathrm{O}$ autor cita exemplos de aparelhos eletrônicos que precisam da energia para recarregar suas baterias e 
ter um funcionamento adequado, e não é porque dependem da energia que são desamparados. Então, ter necessidade, especificamente nesses casos, significa que, sem a energia regulada, os aparelhos estarão paralisados ou prejudicados, diferentemente dos estados afetivos de "falta ou carência" caracterizados aos organismos de fala, capazes de atos intencionais, como os organismos humanos.

Costa (2007, p.62) menciona que Freud, de forma explícita, declara a existência do eu, autorizando o uso do termo desamparo. Esse termo é empregado "diante de um ser de linguagem que pode saber o que é se sentir desamparado, antes ou depois da aquisição da habilidade linguística”.

Falar de desamparo, em uma descrição psicológica dos organismos humanos, justifica-se porque projetamos no outro, adulto ou criança, as qualidades mentais que possuímos ou que eles poderão vir a possuir no curso do desenvolvimento, se trata de crianças. Ao dizermos que o bebê é desamparado porque é prematuro queremos dizer que, em situações similares à da prematuração, sentimos algo que chamamos de desamparo. Essas situações são aquelas em que dependemos de outrem para sobreviver, para viver melhor ou, ao contrário, situações nas quais o sujeito e o outro são impotentes para deterem o risco de morte ou sofrimento. (Costa, 2007, p.62)

A noção freudiana de desamparo foi apresentada, pela primeira vez, em 1895, no "Projeto para uma psicologia científica" (Freud, 1886-1889/1996), no contexto sobre "a experiência de satisfação".

O organismo humano é, a princípio, incapaz de promover essa ação específica. Ela se efetua por ajuda alheia, quando a atenção de uma pessoa experiente é voltada para um estado infantil por descarga através da via de alteração. Essa via de descarga adquire, assim, a importantíssima função secundária de comunicação, e o desamparo inicial dos seres humanos é a fonte primordial de todos os motivos morais [Cf. p.420]. (Freud, 1886-1889/1996, p.370) 
Fortes (2008, p.28), em seu artigo "Masoquismo e desamparo no sofrimento contemporâneo", comenta "a dependência absoluta e radical do outro" do contexto de Freud apontado na citação anterior. O sujeito humano sofre uma pressão interna das "fontes endossomáticas” (frio, fome, dor etc.) em decorrência dos estímulos endógenos, que podem desencadear uma "ação específica" que provoque alguma reação externa e, assim, diminuir a tensão, promovendo uma sensação de alívio.

Quando a pessoa que ajuda executa o trabalho da ação específica no mundo externo para o desamparado, este último fica em posição, por meio de dispositivos reflexos, de executar imediatamente no interior de seu corpo a atividade necessária para remover o estímulo endógeno. A totalidade do evento constitui então a experiência de satisfação, que tem as consequências mais radicais no desenvolvimento das funções do indivíduo. (Freud, 1886-1889/1996, p.370)

Freud (1886-1889/1996), em uma nota de rodapé, explica que o grito do bebê pode ser considerado uma alteração interna. Provavelmente, um pedido de ajuda desse para o outro.

Nessa perspectiva, Fortes (2008) aponta que o bebê precisa ter o outro para realizar a ação específica, mobilizando nesse outro um sentimento de pedido de ajuda para satisfazer suas necessidades. Portanto, ele modifica o meio externo.

É no fato de o bebê precisar da ajuda de um outro que reside o desamparo primordial [...] Portanto, neste momento do "Projeto para uma psicologia científica", o desamparo é equivalente à necessidade de ajuda por parte da criança. Esta precisa de um outro que a acompanhe no caminho em direção à satisfação. (Fortes, 2008, p.28)

Freud (1895/1977 apud Costa, 2007, p.28) assevera que o desamparo inicial dos seres é "a fonte primordial de todos os motivos morais". Isto quer dizer que o sujeito está sempre na dependência e ligado ao outro. "Dizer que o desamparo está na base da moral é 
sustentar como a figura do outro intervém desde o início na formação do sujeito."

Pereira (1999 apud Fortes, 2008) recorda a importância da noção de desamparo para o bebê no início de sua vida, que se manifesta como um processo psíquico, de forma complexa e importante para elaborações posteriores. E ressalta que "Freud desenvolve como as vivências de desprazer do bebê serão interpretadas pelo adulto como sinais de um desamparo radical, constituindo-se numa forma de apelo ao outro" (Fortes, 2008, p.28).

Freud (1925-1926/1996), em "Inibições, sintomas e ansiedade", relata que o desamparo está relacionado com a ansiedade na situação de perigo.

[... ela consiste na estimativa do paciente quanto à sua própria força em comparação com a magnitude do perigo e no seu relacionamento de desamparo em face desse perigo - desamparo físico se o perigo for real e desamparo psíquico se for instintual. [...] Denominemos uma situação de desamparo dessa espécie, que realmente tenha experimentado, de situação traumática. (Freud, 1925-1926/1996, p.161)

Para Freud, a ansiedade "é, por um lado, uma expectativa de um trauma e, por outro, uma repetição dele em forma atenuada”. Entretanto, a ansiedade percorre caminhos distintos; "a origem é diferente". "Sua vinculação com a expectativa pertence à situação de perigo, ao passo que sua indefinição e falta de objeto pertencem à situação traumática de desamparo - a situação que é prevista na situação de perigo" (Freud, 1925-1926/1996, p.162).

Seguindo essa sequência, ansiedade-perigo-desamparo (trauma), podemos agora resumir o que se disse. Uma situação de perigo é uma situação reconhecida, lembrada e esperada de desamparo. A ansiedade é a reação original ao desamparo no trauma, sendo reproduzida depois da situação de perigo como sinal em busca de ajuda. O ego, que experimentou o trauma passivamente, agora o repete ativamente, em versão enfraquecida, na esperança de ser 
ele próprio capaz de dirigir seu curso. É certo que as crianças se comportam dessa maneira em relação a toda impressão aflitiva que recebem, reproduzindo-a em suas brincadeiras. Ao passarem assim da passividade para a atividade tentam dominar suas experiências psiquicamente. (Freud, 1925-1926/1996, p.162)

O perigo da criança, segundo Freud (1925-1926/1996), é de perder o objeto protetor, aquele que a livra da situação de desamparo psíquico e motor. A criança precisa de ajuda do outro para sua própria sobrevivência.

Freud (1925-1926 apud Fortes, 2008, p.28) descreve que "o desamparo é associado ao medo da perda do amor do ser que ocupa a função de protetor. Dada a dependência do sujeito, o perigo maior é o de ser abandonado, deixado à própria sorte e ao próprio desamparo”. Quando se perde o amor do outro, surge a angústia da separação.

Freud (1932-1936/1996) explica que a ansiedade está relacionada com a situação traumática. Segundo ele, o que determina a ansiedade automática é a ocorrência de uma situação traumática, em que resulta uma experiência de desamparo por parte do ego diante de um acúmulo de excitação, podendo ser de origem externa ou interna, com o qual o ego não pode lidar.

A ansiedade, como sinal, é a resposta do ego à ameaça da ocorrência de uma situação traumática. Esta ameaça constitui uma situação de perigo. Os perigos internos sofrem modificações de acordo com o período de vida, mas possuem uma característica comum, a saber, envolvem a separação ou perda de um objeto amado, ou a perda de um amor. Essa perda ou separação poderá conduzir, de várias maneiras, a um acúmulo de desejos insatisfeitos e, assim, levar a uma situação de desamparo. Na ansiedade como sinal, Freud relata que existe um mecanismo pelo qual o ego restringe a geração de experiências dolorosas. Dessa maneira, a libertação do desprazer fica restrita em quantidade, e seu início atua como um sinal ao ego para que este fixe sua defesa normal em funcionamento (Freud, 1932-1936/1996). 
Estabelece-se, assim, uma correlação entre a angústia e o desamparo: "[...] como um fenômeno automático e como um sinal de salvação, verifica-se que a angústia é um produto do desamparo mental da criança" (p.162). A angústia, aqui, de maneira diferente da primeira teoria da angústia, tem a função de um sinal para a evitação de uma situação de perigo, sendo o maior dos perigos a possibilidade da separação da mãe [...] (Freud, 1925-1926 apud Fortes, 2008, p.29)

Reafirmando Freud (1925-1926/1996), a ansiedade é o resultado de um aumento de excitação do ego, podendo produzir o desprazer bem como o alívio por meios dos atos de descarga. Segundo o autor, quando a criança descobre, pela experiência, que um objeto externo perceptível pode pôr termo à situação de perigo, revive o nascimento. Portanto, o conteúdo do perigo que ela teme é a perda do objeto. Entretanto, é a ausência da mãe que agora constitui o perigo, e logo que surge esse perigo a criança dá sinal de ansiedade, antes que a temida situação econômica se estabeleça. Essa mudança constitui a primeira reação de providência adotada pela criança para sua autopreservação, representando, ao mesmo tempo, uma passagem do aparecimento automático e involuntário da ansiedade para a reprodução intencional da ansiedade como sinal de perigo. $\mathrm{O}$ fenômeno automático é um sinal de salvação, e a ansiedade é um produto de desamparo mental da criança, o qual corresponde naturalmente a seu desamparo biológico.

Nessa perspectiva, cabe retornar à afirmação de Rank (apud Freud, 1925-1926/1996, p.147) de que "o processo de nascimento é a primeira situação de perigo, e a convulsão econômica que ele produz torna-se o protótipo da reação de ansiedade".

Pereira (1999 apud Fortes, 2008, p.29) indica a leitura dos seguintes textos para a compreensão do desamparo em Freud: "O futuro de uma ilusão" (1927); "Inibições, sintomas e ansiedade" (1930) e "O mal-estar na civilização” (1930), porque constituem a teorização da problematização do desamparo. Em "O futuro de uma ilusão", Freud compreende o desamparo não como um momento do funcionamento do psiquismo, mas como uma condição que acompanha 
o sujeito por toda a sua existência, como sendo seu destino (Freud, 1927-1931/1996).

Segundo Fortes (2008), o desamparo na concepção freudiana em seu estado inicial era considerado uma imaturidade do ser humano e seria ultrapassável com o seu desenvolvimento. Trata-se da "[...] condição última da falta de garantias do funcionamento psíquico, que o homem tem de enfrentar quando se livra de todas as ilusões protetoras que cria para si mesmo" (Freud, 1930 apud Fortes, 2008, p.29).

Fortes (2008) analisa no texto "O futuro de uma ilusão" que o homem busca nas religiões a figura de um pai, associada ao que é divino. Essa é a proteção para seus perigos, vindos da natureza e do destino, contra todo o sofrimento da humanidade. Freud afirma, em seus escritos, "[...] a desagradável suspeita de que a perplexidade e o desamparo da raça humana não podem ser remediados" (Freud, 1927-1931/1996, p.27). Entretanto, existe o desamparo na criança e no adulto.

As religiões asseguram que o sujeito não ficará desamparado, que terá alguém que não a abandonou e que poderá se sentir protegido e amparado. Em "O mal-estar na civilização", Freud (1927/1931/1996) assinala que o homem deve renunciar seus desejos, ou seja, deixar suas pulsões para viver na civilização, porém deve privar-se do prazer e da agressividade que traz perigo para si e para o outro. Assim, não perderá o amor do outro e não sentirá culpa. Ao mesmo tempo, ganhará as bênçãos dos céus. Com a renúncia de suas pulsões, o homem não correrá o risco de ser abandonado pelo Divino Pai.

Nos desdobramentos posteriores das teorizações matrizes de Freud, Melanie Klein (1946-1963/1991) teve um papel relevante e acabou por fundar uma importante escola dentro do amplo movimento psicanalítico, sobretudo pelas suas contribuições teóricas acerca das ansiedades iniciais que incidem sobre o funcionamento e a estruturação da psique. Basicamente, ela destaca duas ansiedades básicas como modos estruturantes e estratégias utilizadas pelo aparelho psíquico para lidar com os fantasmas que o assaltam, valendo-se das pulsões destrutivas. Segundo essa psicanalista, o sentimento 
de hostilidade e a correspondente divisão do Eu como estratégia básica de enfrentamento, e o sentimento de perda com a correspondente tentativa de produzir a unificação do Eu, do objeto, e de mantê-los ligados constituem os desafios primeiros da vida e instalam modos de funcionamento psicológico que serão ativados ulteriormente. A esses dois modos e estratégias primordiais ela deu o nome de posição esquizoparanoide e posição depressiva. Tais posições são consideradas "estados momentâneos de organizacão do ego" que transitam por toda vida no indivíduo (Klein apud Quinodoz, 1993, p.75).

Para Klein (1946-1963/1991), o início da vida da criança é distinto da visão de Freud, que o denominava narcisismo primário. Klein fala de indiferenciação ego-objeto, que ocorre desde o nascimento, e que a angústia está a trabalho interno da pulsão de morte. De acordo com Klein (1946-1963/1991), é na primeira infância que surgem as ansiedades de cunho psicótico.

Segundo Melanie Klein, no nascimento já existe ego suficiente para experimentar ansiedade, usar mecanismos de defesa e formar relações de objeto primitivas na fantasia e na realidade. Descreve, também, um mecanismo de defesa primitivo, isto é, a deflexão do instinto de morte, que ocorre no início da vida; seu conceito de realização de desejo alucinatório implica um ego capaz de formar uma relação de objeto e fantasia. (Segal, 1975, p.36)

A criança, logo ao nascer, se depara com a pulsão de morte, que éa primeira angústia vivida pela criança. Esta situação é escrita por Klein e denominada angústia de aniquilamento. A criança vai usar de mecanismos de defesa primitivos, como a projeção e a introjeção, para lidar com essa angústia que é projetada para o mundo externo e, assim, vai construindo a fantasia do objeto mau que ameaça o ego de fora. Nem tudo é projetado para fora, por causa dos mecanismos de defesa, projeção e introjeção; uma parte do objeto mau fica no mundo interno da criança, o qual passa a ser o objeto persecutório, e a criança vive uma ameaça também dentro do seu mundo interno. Ao lado do objeto mau, também há um objeto bom introjetado (Quinodoz, 1993). 
Para Segal (1979 apud Quinodoz, 1993, p.75), “[...] a angústia é mais pela perda do objeto bom do que de ser atacado pelo objeto mau". Portanto, podemos pensar que a vivência da perda do objeto bom gera angústia e, em consequência disso, pode resultar num estado de desamparo emocional. Entretanto, o sentimento de culpa que surge na posição depressiva por ter perdido o objeto bom (mãe) internalizado em decorrência das pulsões e fantasias agressivas cria no bebê a fantasia de ter sido abandonado e que a morte será o seu destino.

A esse respeito, Quinodoz (1993) enfatiza que, na posição depressiva, aparecem sentimentos ambivalentes na criança e em suas relações objetais. Surge o medo de perder o objeto amado, em razão de seu ódio e suas pulsões agressivas direcionadas a ele, e de que destrua o objeto do qual depende totalmente. A criança descobre a sua dependência pelo objeto e até sente a necessidade de protegê-lo contra seus próprios ataques destrutivos. Nessa posição, em virtude da onipotência da criança, também irrompe o medo de perder o objeto bom internalizado.

Embora tenha suposto que o resultado da posição depressiva depende da elaboração da fase precedente, atribui, não obstante, à posição depressiva um papel central no desenvolvimento inicial da criança. Isso porque, com a introjeção do objeto como um todo, as relações de objeto do bebê se alteram fundamentalmente. A síntese entre os aspectos odiados e amados do objeto completo dá origem a sentimentos de luto e culpa que implicam progressos vitais na vida emocional e intelectual do bebê. Esse é também um ponto crucial para a escolha da neurose ou psicose. (Klein, 19461963/1991, p.22)

Klein (1946-1963/1991) defende que, quando o ego não consegue elaborar a posição depressiva, esse regride para a posição esquizoparanoide. Surgem os medos persecutórios e os traços esquizoides, que podem desencadear estados de desintegração do ego. Por outro lado, também poderão ser reforçados os traços depressivos. 
Ainda de acordo com Klein (1946-1963/1991, p.24), "a ansiedade de ser destruído a partir de dentro permanece ativa”. Entretanto, a ausência dessa ligação e o ego sob pressão tendem a despedaçar. O ego despedaçado caracteriza os estados de desintegração nos esquizofrênicos.

Klein (1946/1991, p.21) aponta que "a fase persecutória" foi posteriormente denominada de "posição paranoide" e que essa posição vem antes da "posição depressiva".

Para Segal (1979 apud Quinodoz, 1993, p.75), a angústia da posição esquizoparanoide é vivida de forma persecutória e o medo é de que o "[...] perseguidor destrua ao mesmo tempo o ego (self) e o objeto idealizado”. Em decorrência da posição esquizoparanoide, são utilizados os mecanismos primitivos de defesa: a cisão, a idealização e a negação onipotente. Segundo a autora, a frustração é vivida como persecutória e as relações boas são vistas como idealizadas.

A ansiedade, segundo Klein (1946-1963/1991), surge da pulsão de morte sentida dentro do organismo como medo de aniquilamento, e, com isso, se torna o medo persecutório.

O medo do impulso destrutivo parece ligar-se imediatamente a um objeto, ou melhor, é vivenciado como medo de um incontrolável objeto denominador. Outras fontes importantes de ansiedade primária são o trauma do nascimento (ansiedade de separação) e a frustração de necessidades corporais. E também essas experiências são sentidas desde o início como sendo causadas por objetos. (Klein, 1946-1963/1991, p.24)

Portanto, por meio da introjeção, esses objetos se tornam perseguidores internos e perigosos. Sob ameaça, o medo do impulso destrutivo interno é reforçado (Klein, 1946-1963/1991).

$\mathrm{Na}$ gratificação alucinatória, entram os mecanismos de defesa, como a cisão do objeto e a negação, sentidos tanto na frustração como na perseguição. 
O objeto frustrador e perseguidor é mantido completamente separado do objeto bom idealizado. No entanto, o objeto mau não é apenas mantido separado do objeto bom; sua própria existência é negada, assim como são negados toda a situação de frustração e os maus sentimentos (dor) a que a situação de frustração dá origem. Isso se relaciona com a negação da realidade psíquica. A negação da realidade psíquica só se torna possível através de fortes sentimentos de onipotência, uma característica essencial da mentalidade arcaica. A negação onipotente da existência do objeto mau e da situação de dor é, para o inconsciente, igual à aniquilação pelo impulso destrutivo. Entretanto, não são apenas uma situação e um objeto que são negados e aniquilados: é uma relação de objeto que sofre esse destino e, portanto, uma parte do ego, da qual emanam os sentimentos pelo objeto, é negada e aniquilada também. (Klein, 1946-1963/1991, p.26)

Durante o processo de desenvolvimento da criança, várias situações são experimentadas pela separação ou perda, que significa uma ameaça em cada etapa vivida. Para Klein, as primeiras grandes perdas para a criança são o nascimento e o desmame e, consequentemente, a perda do objeto idealizado. Portanto, a separação e as perdas acabam desencadeando "uma reação de luto, acompanhada de tristeza e de nostalgia, o que o torna um elemento da posição depressiva" (Quinodoz, 1993, p.78).

$\mathrm{Na}$ aprendizagem do controle esfincteriano, a criança precisa renunciar às fezes internas idealizadas; o andar e o falar também implicam o reconhecimento de si próprio como individualidade separada. Na adolescência, a dependência infantil deve ser abandonada; na idade adulta, é preciso enfrentar a perda de seus próprios pais e de figuras parentais e, pouco a pouco, a perda de sua própria juventude. A cada etapa do desenvolvimento, é preciso escolher novamente entre regredir, para fugir da dor depressiva, em direção a um modo de funcionamento esquizoparanoide, ou elaborar essa dor depressiva para permitir que o desenvolvimento se complete. Nesse sentido, podemos dizer que a posição depressiva nunca é totalmente 
elaborada: a elaboração completa da posição depressiva levaria a algo com perfeita maturidade. Porém, o grau alcançado de elaboração da depressão e de integração dos bons objetos internos pelo ego determinam a maturidade e o equilíbrio do indivíduo. (Segal, 1979 apud Quinodoz, 1993, p.78)

Klein (1946-1963/1991) postula que é na posição depressiva que o ego pode ser considerado mais integrado, porque pode ter uma visão mais completa de realidade interna e externa, e também enxergar de forma total os dois mundos.

O impulso de reparação que, nesse estágio passa a primeiro plano, pode ser visto como consequência de um maior insight sobre a realidade psíquica e de uma síntese crescente, pois demonstra uma resposta mais realista aos sentimentos de pesar, culpa e medo da perda, resultantes da agressão contra o objeto amado. (Klein, 19461963/1991, p.33)

A reparação para Klein (1946-1963/1991) tem o objetivo de proteger o objeto que foi destruído, assim as relações objetais se tornam mais satisfatórias, e as sublimações das pulsões, mais elaboradas para integração do ego.

Mesmo considerando o excessivo "internalismo" da teoria kleineana, que parece desconsiderar ou não contemplar as condições objetivas nas quais se desenrolam as experiências subjetivas, parece útil recorrer aos conceitos de posição esquizoparanoide e depressiva para compreender alguns aspectos da vivência dos filhos dos dekasseguis.

As crianças, ao migrarem para outro país, acabam se deparando com as angústias persecutórias e depressivas, como se voltassem num tempo de vivências muito primitivas. Essas crianças passam por novos nascimentos, numa linguagem psicanalítica, em todas as suas viagens de mudanças e andanças por esse mundo afora. Entretanto, têm de nascer e desmamar das suas terras-mães, atravessando separações e vários lutos em sua tenra idade. 
A posição esquizoparanoide e a posição depressiva de Melanie Klein descritas nesse contexto nos mostram os estados momentâneos de organização mental em que se encontram essas crianças (e)imigrantes. A negação da realidade psíquica e a onipotência são mecanismos primitivos de defesa do ego; assim, a criança acaba se esquivando do contato com a nova realidade. O sentimento onipotente que surge nessas crianças serve exatamente para preservar o antigo objeto idealizado, no caso o Japão, e evitar que não caiam em desamparo emocional.

A construção e a formação de novos vínculos saudáveis ocorrem quando a criança se encontra mais integrada emocionalmente. $\mathrm{O}$ ego já está mais fortalecido, e os objetos persecutórios, mais controlados. Portanto, é na posição depressiva que a criança (e)imigrante poderá ficar inteira nas relações objetais e perceber, desse modo, o seu estado de dependência pelo objeto e que a ausência do objeto pode desencadear o estado de desamparo. Logo, entendemos que os processos esquizoides e depressivos, presentes no funcionamento psicológico, são ativados ou não dependentes de situações emergentes na relação do sujeito com o outro, com o seu mundo.

Birman (2006) esboça as transformações nas formas de mal-estar na contemporaneidade, as quais são reconhecidas nos discursos psiquiátricos e psicanalíticos. Enuncia o corpo como o registro do mal-estar e a insatisfação do homem. Caracteriza a atualidade como a sociedade dos excessos. A ação, a compulsão, a maneira de agir sem pensar, a falta de tempo e espaço, o vazio no sentir que aparece no psiquismo, tudo isso mostra que o excesso se encontra subjacente. "Em face do excesso, o psiquismo procura dele se livrar pela ação, para não correr o risco de ficar paralisado pela angústia” (Birman, 2006, p.183). O corpo também é um meio através do qual o psiquismo se livra da angústia.

À vista do que expusemos até aqui, podemos concluir que, em qualquer tempo, o indivíduo pode regredir e usar de mecanismos de defesas arcaicas. O homem parece fugir de sentir-se desamparado, mobilizando uma série de ansiedades primitivas contra esse sentimento. $\mathrm{O}$ homem volta no mundo infantil para tentar buscar 
o aconchego do objeto primário. Assim, a contemporaneidade é caracterizada pelo tempo de desamparo, pelo individualismo, pelo isolamento, no qual o outro tende a representar mais uma ameaça do que uma segurança.

A criança (e)imigrante, em sua curta história de vida, traz consigo marcas profundas das condições atuais de mobilidade e desamparo vivenciadas na (e)imigração. O sofrimento emocional desencadeado por esse trânsito migratório percorre por toda uma vida. 


\section{5. \\ CONHECENDO A FAMÍLIA: PAIS DEKASSEGUIS E FILHOS IMIGRANTES}

\section{Pais de Eiko e Letícia: sr. Ito / sra. Natsu}

O primeiro contato com o senhor Ito foi feito por telefone. O senhor Ito, pai das crianças Eiko e Letícia, ligou para dizer que tinha interesse em participar da nossa pesquisa voltada aos filhos de dekasseguis que retornam ao Brasil. Ele obtivera a informação sobre a pesquisa no Nikkei Clube de Marília.

O pai das crianças Eiko e Letícia tem 39 anos de idade, cursou o ensino médio no Brasil. Há quinze anos imigrou para o Japão. O senhor Ito é sansei, ou seja, terceira geração de descendentes de japoneses. Ele foi para o Japão em 1992, quando tinha 20 anos de idade. O seu último emprego no Japão foi numa fábrica de componentes eletrônicos, onde trabalhava no setor de almoxarifado, no período da manhã e à noite. Antes de ir para o Japão, era feirante. O que o fez emigrar para o Japão foi a intenção de adquirir uma casa própria no Brasil.

A mãe das crianças tem 33 anos de idade, concluiu o ensino médio no Brasil. A mãe, que chamaremos de Natsu, também é sansei, ou seja, neta de japoneses. Aos 17 anos de idade, em 1997 deixou o Brasil e foi para o Japão. Em seu último emprego, a senhora Natsu trabalhava em um hotel no Japão e desempenhava vários tipos de 
funções, desde arrumadeira de colchões até em eventos para festas. Sua jornada de trabalho era de quatro horas diárias, de domingo a domingo, o que permitiria ficar parte do tempo com as crianças. O motivo que a levou a emigrar para o Japão foi o desejo de formar uma poupança para cursar uma universidade no Brasil.

A senhora Natsu diz saber falar e escrever o idioma japonês. O senhor Ito também afirma falar o idioma japonês, porém tem menos conhecimento na escrita da língua em relação à sua esposa.

A família de Eiko e Letícia já se encontrava no Japão em 2003 e retornou para o Brasil em meados de 2009, após o Japão ter entrado em recessão, a qual fora desencadeada pela crise financeira global e somada à falência do banco Lehman Brothers, que ocorreu em setembro de 2008. Como outros milhares de dekasseguis, o senhor Ito fica desempregado. A senhora Natsu continua trabalhando no hotel, mas o seu salário não sustenta a família, já que trabalha um período de quatro horas diárias. A decisão de retornar ao Brasil é tomada pelo pai das crianças.

O senhor Ito e a senhora Natsu foram solteiros para o Japão e se conheceram lá. Vieram para o Brasil para o senhor Ito pedir a mão dela em casamento aos sogros. Casaram-se no Brasil e retornaram para o Japão. O senhor Ito refere-se à família como uma família muito tradicional e que gosta de tudo certinho. Quando retornaram para o Brasil, em 2009, o casal veio acompanhado das duas filhas.

No Brasil, o casal investiu em um negócio comercial. A família do senhor Ito estava residindo em uma edícula que é a casa dos pais da senhora Natsu, avós maternos das crianças. Os avós maternos das crianças permaneceram no Japão por mais alguns anos e retornaram para o Brasil em meados de 2012. Atualmente, estão morando todos juntos numa casa maior, a família do senhor Ito, os avós maternos e mais uma tia materna com três filhos que também retornaram em 2012 do Japão, por causa da crise econômica que vem afetando o país.

No primeiro contato, o casal formado pelo senhor Ito e pela senhora Natsu chegou no horário marcado; ambos usavam trajes sociais, típicos de um encontro formal. A senhora Natsu expressava-se 
em um tom de voz um pouco mais baixo do que estamos acostumados a ouvir; sua voz era suave e ela apresentava um comportamento delicado. O casal tinha traços físicos japoneses.

Uma entrevista foi realizada com casal, com duração de 2 horas, no dia 12/4/2012.

Apresentaremos, a seguir, os casos Eiko e Letícia.

\section{Caso Eiko}

A adolescente Eiko está com 13 anos de idade, nasceu na cidade de Matsumoto, na província/estado de Nagano, região central do Japão. Depois do nascimento de Eiko, os pais ficaram por um período de seis meses no Japão e, em seguida, vieram para o Brasil e permaneceram por mais de dois anos. Antes de Eiko completar 3 anos de anos de idade a família retornou ao Japão. Os pais relatam que sua filha Eiko diz ser japonesa, porque nasceu no Japão. No seu registro de nascimento, apesar de constar o nome da cidade em que nasceu, Matsumoto/Japão, Eiko não é uma japonesa nata, mas sim uma brasileira.

No Japão, Eiko frequentou creche e escola japonesas. Havia terminado o terceiro ano do ensino fundamental. Na escola japonesa, Eiko apresentou dificuldades com a escrita denominada kanji, ${ }^{1}$ tendo que frequentar aulas de reforço do idioma japonês. No Japão há outras formas de escrita, o hiragana, ${ }^{2}$ o katakana, ${ }^{3}$ e o romaji. ${ }^{4}$ No arquipélago oriental, mesmo que Eiko se considerasse uma japonesa, ela era uma estrangeira na terra dos seus antepassados. A comunicação em casa com os pais ocorria no idioma japonês. A adolescente Eiko, no Japão, não tinha contato com a língua portuguesa.

1 Kanji: forma de caracteres da escrita japonesa.

2 Hiragana: forma de escrita japonesa. O hiragana é usado para palavras de origem japonesa.

3 Katakana: forma de escrita japonesa. O katakana é usado para palavras de origem estrangeira.

4 Romaji: o alfabeto romano. 
Quando Eiko veio para a primeira entrevista, estava com 12 anos e meio. Eiko apresentava todos os traços físicos e comportamentos de uma criança nipônica: a timidez, a delicadeza de uma pequena japonesinha. Ela costuma se vestir à maneira das adolescentes nipônicas: tênis, saias curtas e meias acima dos joelhos. Quase não se ouve o som de sua voz, misturada com uma fonética trêmula, entrecortada, como se não pudesse fazer uma ligação entre as palavras faladas com a língua portuguesa. As palavras eram ditas com muita dificuldade; a sua forma de se expressar e de andar tinham um jeito contido, era diferente do comportamento de uma criança brasileira. No entanto, Eiko é filha de brasileiros, uma brasileira nascida no Japão. Diante das circunstâncias da crise econômica japonesa, ela, aos 9 anos e 9 meses de idade, teve de retornar para o Brasil com os pais, sem saber o idioma português. Ao chegar ao Brasil, Eiko se deparou com as diferenças culturais e as dificuldades de adaptação para se reintegrar ao novo e desconhecido país, o qual não considerava seu país de “origem”, e sim o país de "destino", que ela não escolheu para viver. Atualmente, sua voz está mais fortalecida, porém as dificuldades de adaptação ainda persistem, principalmente com a língua portuguesa e com o estabelecimento de vínculos de amizades. O comportamento japonês permanece imbricado no jeito de ser de Eiko.

A adolescente Eiko frequenta a $7^{\mathrm{a}}$ série $/ 8^{\circ}$ ano, reprovou a $4^{\mathrm{a}}$ série $/ 5^{\circ}$ ano, pois tinha acabado de chegar ao Brasil, em julho de 2009, e estava com quase 10 anos de idade. As duas irmãs ingressaram na escola brasileira em agosto de 2009, sem saber o idioma português. Seus pais, durante esse período, contrataram professores particulares para ensiná-las. Também se dispuseram a estudar junto com as filhas. No entanto, Eiko não consegue falar fluentemente a língua portuguesa, continua apresentando muitas dificuldades de compreensão das formas mecânica e subjetiva da língua portuguesa. Além disso, tem vergonha de se expressar, acaba se isolando e não tem amigos.

No período de 19/4/2012 a 2/7/2013 foram realizadas 24 entrevistas com a adolescente Eiko. A entrevista gravada teve a duração 
de 16 minutos. Utilizamos desenhos para a compreensão do desamparo emocional da criança.

\section{Caso Letícia}

A filha caçula Letícia tem 10 anos de idade, nasceu no Brasil, na cidade de Tupã/estado de São Paulo, e, portanto, é brasileira nata. Antes de completar um ano de idade, foi para o Japão e retornou para o Brasil com 7 anos completos. Quando Letícia veio até o nosso consultório pela primeira vez, já tinha 9 anos de idade. No Japão, frequentou a creche e iniciou a primeira série na escola japonesa. No Brasil, a filha caçula entrou na $1^{\mathrm{a}}$ série $/ 2^{\circ}$ ano, em uma escola particular. Ela está conseguindo acompanhar o currículo da escola brasileira, tendo sido alfabetizada no Japão e no Brasil.

A criança Letícia, como a sua irmã Eiko, é delicada, magra, parece uma bonequinha japonesa. Seu comportamento contido a diferencia das crianças brasileiras. Apresenta traços físicos japoneses, costuma usar roupas parecidas com o tipo de vestimentas de crianças nipônicas.

Letícia fez algumas amizades na escola em que estuda. Está cursando a $5^{\mathrm{a}}$ série $/ 6^{\circ}$ ano. Os pais dizem que Letícia afirma que estudou em escola japonesa e aprendeu a cultura do país, e por isso pretende voltar para o Japão. A caçula fala fluentemente os dois idiomas, o português e o japonês.

Diferentemente da irmã Eiko, Letícia não teve nenhuma reprovação escolar. No entanto, apesar de ter mais facilidade para aprender o novo idioma, o português, ainda tem encontrado muitas dificuldades na construção abstrata da língua. Diz que não consegue compreender os significados das palavras e que se cansa de procurá-las no dicionário de língua portuguesa, vivendo um desânimo que ela mesma chama de "preguiça".

As crianças Eiko e Letícia sempre estudaram em escolas japonesas e não aprenderam a língua portuguesa. Em casa, os pais se comunicavam com as filhas na língua do país de destino. Os pais justificam que as escolas brasileiras no Japão não oferecem profissionais 
especializados nem têm uma estrutura física e metodológica de ensino considerada adequada, totalmente diferente da escola japonesa. E, por isso, optaram por matriculá-las em uma escola japonesa.

No contato com o aprendizado da língua portuguesa, as irmãs Eiko e Letícia choravam constantemente. O relato trazido pelas crianças é que a língua portuguesa é muito difícil de ser compreendida e que o comportamento das demais crianças brasileiras as assusta.

Foram realizadas 23 entrevistas com a criança Letícia, no período de 3/5/2012 a 2/7/2013. A entrevista gravada teve a duração de seis minutos. Utilizamos desenhos para a compreensão do desamparo emocional da criança.

\section{Mãe da criança Goro: sra. Haru}

A senhora Haru havia acabado de chegar ao Brasil quando tivemos o nosso primeiro contato. Ela nos procurou interessada em participar da pesquisa do retorno dos filhos de dekasseguis ao Brasil. A mãe da criança Goro teve conhecimento da realização da pesquisa por intermédio da irmã, Natsu.

A senhora Haru é sansei e tem 30 anos de idade. Tem traços físicos japoneses. Sabe falar fluentemente o idioma japonês. Frequentou uma universidade estadual no Brasil, antes de ir para o Japão, porém não conseguiu concluí-la.

A senhora Haru estava grávida de seis meses quando se casou. Relata que a gravidez foi o motivo para casar-se. Durante o namoro, ela engravidou do pai de Goro. Diz: "Fiquei grávida antes de casar e por isso parei com a universidade".

A separação ocorreu um ano após seu casamento e aconteceu de forma amigável. A família da senhora Haru nunca aceitou o seu casamento, porque o seu marido não conseguia ter um emprego estável e não demonstrava confiança. O pai de Goro tem o ensino fundamental completo e não tem descendência japonesa, mas sim afrodescendência. Quando se casaram no civil, foram morar separados; a senhora Haru ficou na casa dos pais e o marido, na dos pais dele. $\mathrm{O}$ 
relacionamento era conturbado e a senhora Haru pediu a separação ao pai de Goro. Em 2005, quando Goro tinha um ano e nove meses de idade, a senhora Haru, aos 23 anos, e sua mãe foram trabalhar no Japão. Como dekassegui, trabalhou de operária em uma fábrica e conseguiu um cargo de liderança. Permaneceram no Japão por sete anos sem retornar ao Brasil. Moraram na província de Nagano, na cidade de Matsumoto.

No último serviço no Japão, trabalhou numa fábrica na linha de montagem de cartuchos para impressora e, com o tempo, conquistou uma posição de líder por saber falar o idioma japonês. Como líder dos brasileiros, também fazia a tradução da língua japonesa para os dekasseguis brasileiros e da língua portuguesa para os líderes japoneses da fábrica. A senhora Haru fazia a intermediação entre japoneses e brasileiros desenvolvendo a função de intérprete no trabalho. Nesse serviço, fazia três horas extras diárias ou mais, não dispondo de tempo para ficar com o filho. A avó materna de Goro trabalhava oito horas diárias; após o término do horário de serviço, tinha o compromisso de buscar o neto Goro na creche.

No Japão, a senhora Haru conheceu o seu atual companheiro, com quem tem um relacionamento estável há cinco anos. Ele também é sansei, mestiço, com quem teve mais dois filhos, um menino de 3 anos de idade e o outro de um ano e meio.

No Japão, a língua falada dentro de casa era a japonesa. A senhora Haru diz que a criança, por frequentar a escola japonesa, usava o idioma japonês para se comunicar em família.

A senhora Haru retornou em maio de 2012 para o Brasil com os seus pais. No Brasil, foram morar com a irmã mais velha, os dois sobrinhos e o cunhado. Atualmente, a irmã mais velha mora em outra casa. A família do senhor Ito passou a morar na mesma casa da senhora Haru, em companhia dos avós maternos. Essa casa pertence aos avós maternos das crianças. O companheiro da senhora Haru permaneceu trabalhando por mais um ano no Japão antes de retornar, em maio de 2013.

O menino Goro não conhece e não tem nenhum contato com o seu pai biológico. A mãe diz que o filho não sabe da sua história 
de vida. Goro considera a sua família os avós maternos, a mãe e o padrasto, a quem chama de "titio". Define o pai como aquele quem cria. A mãe relata que a criança não demonstra interesse em conhecer o pai biológico, porém teme um reencontro do filho com seu verdadeiro pai. A mãe justifica que pai e filho se parecem e que teme esse reencontro.

A entrevista gravada com a senhora Haru no dia 28/6/2012 teve duração de 28 minutos. Tivemos mais um contato, no dia 16/8/2012, quando a senhora Haru esteve acompanhada do filho, que não consegue falar a língua portuguesa. $\mathrm{O}$ diálogo com os dois ocorreu no idioma japonês, e foi realizada a tradução para o idioma português.

\section{Caso Goro}

A criança Goro tem 10 anos de idade, é natural da cidade de Bastos, estado de São Paulo. No primeiro contato, a criança parecia estar retraída, assustada com o novo meio, seu olhar era cabisbaixo. Seu comportamento era esquivo dentro do entorno. Goro se encontrava num ambiente desconhecido; além do mais, não falava a língua portuguesa, apresentando certa resistência em criar vínculos. A princípio, queria a companhia da mãe, a senhora Haru. Por possuir conhecimento básico em língua japonesa, passamos a fazer uso do idioma japonês. Com um vocabulário simples da língua, eu perguntei para a criança se ela estava bem. A criança arregalou os olhos, demonstrando surpresa ao ver que nos comunicávamos com ela na mesma língua do seu conhecimento. A partir desse episódio, iniciou-se o nosso diálogo, na língua japonesa, e em todos os nossos contatos utilizamos expressões japonesas.

Goro é uma criança mestiça japonesa, porém seus cabelos são encaracolados, e os olhos, mais amendoados, o que o difere fisicamente do japonês nativo. Sua mãe, a senhora Haru, fala que seu filho Goro se sentia complexado no Japão por ser fisicamente diferente dos 
japoneses. A criança queria ser igual aos japoneses e se achava uma criança feia.

No Japão, quando era Dia dos Pais, a criança ficava triste. A professora pedia para fazer um desenho, porém a criança desenhava a figura da mãe ou da avó no lugar do pai, ou seja, preenchia essa ausência com figuras femininas.

A criança ingressou na escola Kumon ${ }^{5}$ para aprender o idioma português e também a matemática, a qual frequentou durante sete meses. A forma de calcular a matemática na escola brasileira é diferente do sistema de ensino japonês. A senhora Haru optou por alfabetizar a criança primeiro na escola de idiomas, antes de matriculá-la numa instituição de ensino brasileira. A criança terminou a segunda série no Japão.

A criança Goro, no Japão, havia sido aprovada para a $3^{\mathrm{a}}$ série, mas chegou ao Brasil em meados de 2012 e não foi diretamente matriculada na escola de ensino fundamental, quando tinha 9 anos de idade. Goro foi matriculado, no início de 2013 , na $3^{\mathrm{a}}$ série $/ 4^{\circ}$ ano, numa escola particular. A mãe pediu à direção para colocá-lo na $3^{\mathrm{a}}$ série, porque o currículo escolar do no Japão era diferente do Brasil. Dessa forma, não daria sequência ao ano escolar real, que seria a $4^{\mathrm{a}}$ série. Iniciaria a $3^{\text {a }}$ série, que não cursou nem no Japão nem no Brasil. Goro ficará um ano escolar atrasado em relação à sua idade cronológica. A criança vem apresentando dificuldades nas disciplinas de português, ciências e história, mas tem conseguido alcançar a média nas avaliações.

Ficamos impossibilitados de gravar a primeira entrevista com Goro por ele não falar o idioma português e por tratar de expressões abstratas.

Foram realizadas onze entrevistas com a criança Goro, no período de 5/7/2012 a 6/7/2013.

5 Kumon: escola de idiomas (japonês, português, inglês) e matemática. 


\section{Breve comentário}

Essas três crianças somente estudaram em escolas japonesas. Aprenderam a falar e a sentir a linguagem do mundo oriental, totalmente oposta à do mundo ocidental.

A comunicação dentro de casa ocorria no idioma japonês, portanto, a língua portuguesa permaneceu ausente durante anos para essas crianças, que, de forma repentina, viram suas vidas em outro mundo, entraram em contato com outro idioma que não era o japonês, mas o idioma português. 


\section{6. \\ MUNDO DE LÁ E MUNDO DE CÁ: OS DOIS LADOS DA EXPERIÊNCIA DO IMIGRANTE E SEUS DESAFIOS}

\section{Pais dekasseguis}

\section{Pais dekasseguis: retorno ao Brasil}

Para os pais dekasseguis, as dificuldades de retorno para o Brasil se iniciam antes mesmo da chegada ao país. Os pais demonstram preocupações com a vida escolar dos seus filhos, pois como o ano letivo japonês se inicia em abril, ocorre o desajuste com o ano letivo brasileiro. A criança chega ao Brasil "atrasada" ou "em déficit" em relação ao tempo escolar brasileiro. E essas diferenças já despontam no Japão, em virtude de o cronograma escolar japonês ser diferente do cronograma escolar brasileiro. Diz o senhor Ito:

Na verdade, a dificuldade já começa lá no Japão. Você vai sair de lá e medo de crianças, escola. O ano letivo lá não casa com o ano letivo daqui. Então, esse é um problema muito grande nessa questão. Porque lá, eles seguem o ano, seguem a estação. Termina assim, quando termina o inverno e começa a primavera. Em abril começa a primavera. Tem esse problema, que na verdade ela termina o ano lá e já se inicia ano letivo aqui. Praticamente é fevereiro que se começa. Já perderam uns meses. Tem essa questão. Termina uma série lá e teoricamente 
para ela continuar essa mesma série aqui é difícil. Acaba retrocedendo. É feito um levantamento mais ou menos de conhecimento para ver onde que ela serve. Que não dá para voltar para o primeiro ano. Tem que ser engajada.

Quando chegaram ao território brasileiro, a atitude dos pais foi de tirar tudo que se referisse e representasse o Japão de Eiko e Letícia, como filmes, mangás ${ }^{1}$ e a língua japonesa. Exigiram que elas usassem somente o português para se comunicar dentro de casa. Os pais disseram que não adiantou nada ter tomado esse tipo de atitude com as filhas. As crianças constantemente choravam diante das dificuldades em aprender a nova língua. Durante os seis primeiros meses, os pais mantiveram essa conduta em relação às filhas. Após esse período, fizeram o processo inverso e resolveram matriculá-las no Nikkei Clube, para terem contato com a língua japonesa. No clube japonês a adolescente Eiko passou a se sentir em casa, encontrou um espaço onde podia falar a língua japonesa. Ela tornou-se uma adolescente comunicativa e se integrou com as demais crianças. Entretanto, diferentemente do que ocorre na escola regular, Eiko vive sozinha, não tem amigos e se isola.

Por incrivel que pareça, nesse meio termo, depois de meio do ano desse sofrimento, percebemos que não havia melhora, não havia avanço. Por incrível que pareça, a gente fez ao contrário. Procuramos a escola. Na verdade estávamos tentando procurar alguma coisa que motivasse ela no Brasil. Que não era o fim. Que existia, que escola oferecia, tinha teatro e aula música, tinha um monte de coisa. Vamos tentar. Tentando achar alguma coisa que fora os horários de estudos que a gente estava proporcionando, ter alguma coisa que fosse meio lazer e... Era brincadeira aprender. Não estávamos encontrando. Por incrível que pareça, depois de seis meses a gente resolveu colocar na escola japonesa. Totalmente o oposto que todo mundo falou. Mas foi realmente

1 Mangás: história (f) em quadrinhos, desenho (m) animado, tira (f) cômica, cartum (m) (Hinata, 1998, p.263). 
onde ela se encontrou de novo. Que é muito engraçado isso daí, porque é totalmente ao contrário. Foi de contramão. Ela gosta. Na escola japonesa são duas vezes por semana. São três dias na semana. A sexta-feira é cultural, é uma brincadeira, é uma parte mais cultural.

Os pais desorientados e desamparados, ao chegarem ao Brasil, procuraram alguma solução para lidar com as dificuldades que estavam enfrentando em família.

A irmã Letícia diz sentir-se bem no clube japonês. A caçula frequentou a mesma sala que sua irmã Eiko, onde estavam as crianças com um nível maior de conhecimento na língua japonesa. Entretanto, os pais, no ano passado, tiveram que retirar suas filhas do Nikkei Clube, por não terem condições financeiras de mantê-las na instituição. As duas irmãs sonham em retornar para o Nikkei Clube, pois lá não se sentiram desamparadas.

A criança Letícia é comunicativa e rapidamente constrói laços de amizades. Letícia, apesar da pouca idade e das dificuldades com o aprendizado na língua portuguesa, está conseguindo se desenvolver bem na escola - ao contrário da irmã Eiko, que já havia se alfabetizado e estudado até a terceira série numa escola japonesa.

Diante das dificuldades das primas Eiko e Letícia e da mãe delas, a tia Natsu, a senhora Haru decidiu matricular Goro na escola de idiomas, para se alfabetizar na língua portuguesa. O método de ensino dessa escola é o japonês. Lá, a criança Goro teve contato pela primeira vez com o aprendizado da língua portuguesa, e, dessa forma, ele inicia a sua alfabetização no Brasil.

A mãe Haru, estando muito preocupada com o aprendizado do filho, também o matricula na mesma escola para aprender matemática. No entanto, após ter frequentado essa escola por sete meses, Goro teve que deixá-la, pois sua mãe não pôde mantê-lo, uma vez que iniciaria o ensino fundamental numa escola particular.

A senhora Haru relata seus estranhamentos em relação ao funcionamento do Brasil: 
Eu pelo menos estou sentindo muito! A gente sente primeiro a falta das coisas. A gente fala: Ah, derramou! Então, vamos pegar a caixa de lenço e não tem. É muita coisa que a gente acostuma com o conforto, que a gente tem lá no Japão, com a praticidade. Lá é tão prático. Você vai lá pagar as contas, já tem na esquina uma loja de conveniência. Lá tem tudo, vinte e quatro horas. Aqui não, fecham. Lá também as lojas também não fecham, como aqui fecham. Nossa! A gente sente uma falta. Nossa! Que falta que me faz o Japão nessas horas. Com relação às outras coisas não sinto falta, dificuldades.

Ela continua:

Agora, as crianças também estão sentindo um pouco: a comida que é diferente, até os chocolates para eles "é diferente", porque é mais doce e mais forte, eles não comem. Biscoitos assim também, não é qualquer coisa que eles comem. Eu falo: "Nossa! Como é difícil comprar coisas para vocês!". Porque isso não come e aquele não come. Tem que ficar vendo o que eles gostaram para comprar. É sempre um ou outro. O meu mais velho tem muita mania de não querer experimentar. Primeira coisa ele olha e fala: "É ruim". Eu falo: "Experimenta! Experimenta!". Aí, ele come e vê que é diferente, aí fala que é gostoso. Aí ele come. Comigo no caso a saudade do pai que ficou, do tio. Estão sentindo muito. As coisas, realmente a praticidade. A gente sente muita falta, que a gente fica mal acostumado. Você tem tudo na mão, na hora que você quer, você já tem. Aqui não. Você fala assim: "Como a gente vai fazer?". Não tem. Então, tem que lavar roupa, limpar a casa, tudo e tudo muito trabalhoso. Quando a gente vê a diferença, a gente fala: "Nossa! Que saudade do Japão!”. A gente acaba acostumando.

Ao retornar para o Brasil, o dekassegui faz muitas comparações entre os dois países, entre elas as diferenças cotidianas, como a nova alimentação. A idealização do país japonês surge em seus relatos: lá no Japão é tudo muito mais prático e menos trabalhoso do que no Brasil. O objeto bom e idealizado pelos pais e os filhos de dekasseguis é o país estrangeiro, o Japão. Lá, a preocupação maior era com o 
emprego; no Brasil nasce um novo olhar, o olhar para a casa, para a família, o qual é denominado "trabalhoso".

\section{Experiência de desamparo dos pais dekasseguis}

Para os dekasseguis que moram no Japão há anos, a viagem de retorno para seu país de origem (Brasil) parece ficar cada vez mais distante de sua realidade como imigrante. Os dekasseguis acabam adiando a viagem de volta à terra natal, deixando-a para o futuro, como se não pudessem determinar ou estabelecer um "fim" para a vida de imigrante no Japão. O desejo de retorno ao Brasil permanece nos dekasseguis, é algo que se mantém vivo com o passar dos anos, mas o tempo de partir do Japão rumo ao solo brasileiro é muito difícil, já que estariam então adaptados à vida japonesa.

De acordo com o senhor Ito, após certo tempo de permanência no Japão, os valores vão mudando. Quando foi para o Japão, buscava conquistar sua casa própria. Porém, casou-se e teve as filhas. O senhor Ito e a família passaram a não visar somente ao dinheiro: deram prioridade para os momentos da vida que estavam vivenciando, já que não é possível ser "imigrante de retorno" perante as fases da vida. Portanto, o tempo passado é um caminho que não tem volta, a não ser através das lembranças.

Na verdade é econômica, né? Eu vim de uma criação mais simples. Eu trabalhei, era comerciante, era feirante, né? A gente busca sonhos. Lógico, dar condições. Seria iniciar algo. É tão engraçado, eu saí daqui com um sonho. Vamos lá e adquirir uma casa própria, coisas assim. Porque realmente, por isso que há quinze anos atrás eu saí daqui em época de inflação, não tinha nem Plano Real. Fui lá e ela foi depois. Conheci ela lá. Casamos. Retornamos. Nesse tempo todo você começa a medir a questão valores. O que você valoriza mais? Será que tudo éo dinheiro, será que não é? Acaba mudando um pouco. Aquela primeira ideia que a todo custo e fazer o seu pezinho de meia vai mudando. Então, o nosso caso não foi diferente. Foi lá e acabou mudando certos 
valores. Foi o que realmente... Acho que tudo tem o momento certo para fazer e se você não aproveitar esses momentos para fazer, depois não faz mais. Realmente tem que aproveitar [...].

No caso da senhora Natsu, a sua ida para o Japão foi para realizar o sonho de cursar uma faculdade no Brasil. Para isso, teria de fazer uma boa poupança lá. "Eu saí aos 17 anos daqui. Eu terminei o colegial e já fui para lá. Fui com a intenção de voltar para pagar uma faculdade."

Sempre falávamos assim: "Se um dia voltarmos para o Brasil, como vai ser? Será que a gente não poderia investir não no ramo de eventos?". Lógico, todo mundo sonha. Quem está lá sonha em voltar, adquirir e ter um negócio. Ter alguma coisa própria. Foi aí que a gente se lançou nesse projeto.

O Japão, apesar de ser um país de Primeiro Mundo, tem passado por recessões. Com a crise global que ocorreu em 2008, o país viveu uma das piores crises econômicas de sua história. Milhares de imigrantes que trabalhavam no país foram demitidos das indústrias. Esses imigrantes viram, de uma hora para outra, o seu mundo desabar; ficaram sem emprego, sem dinheiro, sem chão e sem escolhas. O caminho de volta ao Brasil seria a única saída naquele momento. Muitos dekasseguis ficaram sem esperança e viram seus sonhos serem interrompidos. Até então, as recessões eram conhecidas pelos dekasseguis como de curta duração, de apenas alguns meses. A recessão de 2008 parecia não ter fim, levando muitos dekasseguis a voltar para casa. A terra japonesa, idealizada pelos dekasseguis, era vista como aquela que poderia dar bons frutos aos seus filhos imigrantes. No entanto, esses filhos imigrantes do Japão passam a ver o outro lado dessa terra: a mãe real, antes rica, agora empobrecida, sem recursos para dar a seus filhos, que não são natos, mas que adotaram, psicanaliticamente falando, a terra japonesa como sua mãe.

É na crise. Da quebra do Lehman Brothers. Da crise imobiliária que teve nos Estados Unidos. Então, afetou muito o Japão, né? Foi 
uma época difícil. Não tinha muito serviço. Também queria pegar aquele auxílio desemprego. [...] Chegou. Nunca vi uma crise tão forte no Japão. De você sentir muito ruim. Os brasileiros saíam "teiji”" [17 horas]. Realmente quando nunca tinha imaginado aquilo. Foi realmente incrível.

Com a crise econômica japonesa, o pai de Eiko e Letícia ficou desempregado. O senhor Ito relata que o motivo de voltar para o Brasil foi a perda do emprego. Os pais dessas crianças vivem momentos de incertezas, como se não pudessem enxergar mais o futuro para sua família no Japão. Portanto, a vida da família no Brasil é sentida pelo senhor Ito como algo incerto.

Exatamente! Qual que seria? Na verdade é assim, onde você se lança e fala assim: "O que conta no bolso? Ou espera?". Realmente vê e utiliza das suas economias e o que pode ser feito. Lógico, na verdade o retorno para o Brasil você lança do mesmo jeito. Quer dizer, a diferença básica na verdade você não consegue mais ver, prever o futuro, daquela maneira que a gente se previa. Vamos fazer um cálculo anual e pronto, fica sem saber direitinho. Como agora também. Atualmente monta uma empresa e a gente não sabe bem o dia de amanhã. Até pelo menos você conseguir formar e engajar a empresa fica complicado mesmo. O momento de incerteza. Com certeza, infelizmente é ruim. É ruim para todo mundo. Na verdade a incerteza é ruim. No momento a gente resolveu assim, né? Naquela época da crise pensava em ser empreendedor mesmo, já que era obrigado a viver pela incerteza, né?

Diante dessa crise japonesa, a família do senhor Ito decide voltar para o Brasil. A decisão do retorno foi tomada pelo pai das crianças.

[...] eu tomei toda essa decisão de retorno. A gente acabou mudando todo o foco do projeto. A busca de, não vou dizer que é só minha... A gente passou por uma consequência. Na verdade, não foi uma escolha para

2 Teiji: horário (m) ou período (m) estabelecido (Hinata, 1998, p.465). 
elas. Não foi uma escolha que elas: "Ai então, vou embora". Na verdade eu preciso ir. Falei: "Vamos voltar. Vamos ver como vai ficar". Isso realmente engana muito, porque não dei um fator de escolha para elas.

A senhora Haru e as crianças estavam se sentindo inseguras em relação aos abalos sísmicos da terra japonesa. Em decorrência do grande maremoto de nove graus na escala Richter que ocorreu na região de Myagi, em março de 2011, milhares de pessoas perderam a vida. Além disso, a situação agravou-se mais ainda com o vazamento radioativo da usina nuclear de Fukushima, que foi fortemente atingida pelo terremoto, contaminando o reservatório de água. As populações japonesa e estrangeira tiveram que conviver constantemente em estado de alerta, por causa dos terremotos que vinham ocorrendo em todo o país, em consequência desse maremoto. Acrescente-se a isso a crise econômica, que continuava gerando altas taxas de desemprego no país. Esses fatores acabaram mobilizando a família de Haru para retornar ao Brasil. Alguns familiares já haviam voltado. Restava-lhe a única alternativa no momento. O retorno para a terra de origem seria a decisão mais sensata e viável, após sete anos morando em terras japonesas. A decisão de voltar foi tomada pela mãe da criança.

PESQUISADORA: Quando vocês decidiram retornar, ele foi informado? Você pediu a opinião dele? SRA. HARU: Eu falei primeiro que a gente estava voltando. Uma, pela condição do Japão, né? Já estava apresentando risco. Nós já presenciamos o terremoto, lá em Nagano, apesar de ser um estado longe, nós sentimos. Abalou. Até que as crianças ficavam meio assim, toda vez que ficava balançando as coisas, eles ficavam com medo. Até tinha deixado uma bolsa de emergência junto, perto, quando acontecesse alguma coisa pra a gente poder correr, né? Então, eu falei assim, pra gente não sentir essa insegurança. Ele falava: "Para onde a gente vai correr né?", "Pra onde a gente tem que ir? Para onde a gente tem que ir?". Então, acho melhor a gente voltar para o Brasil, que lá já é um país mais assim, lá não tem essas coisas. E também a questão financeira lá e aqui vai dar na mesma. Porque lá a 
gente está trabalhando, mas já está gastando tudo só pra viver e não dá mais nada pra guardar. Então, a gente precisa voltar, né? Também tem essa questão, nós não somos japoneses e nunca vamos ser. Então, é bom voltar para onde é o nosso lugar, né?

Partir ou deixar um país não é fácil para os adultos - que dirá para essas crianças, que precisam deixar o seu mundo de uma hora para outra. Elas parecem sofrer caladas a separação e o processo de luto. Mesmo com os pais por perto, a criança sofre por deixar o seu mundo e partir para outro país, mesmo que seja um lugar conhecido por ela. A tristeza da criança Goro percebida por sua mãe na despedida dos amigos e da sua escola no Japão é um sintoma da separação.

Ele ficou triste. Tanto que, até o último dia de aula, ele ficou meio assim. Não quis despedir dos colegas. Entregou os presentinhos, que é hábito quando sai da escola, sai da creche, sai de algum lugar, você entrega para cada criança alguma lembrança, né? Então, ele levou, entregou para crianças e professores, mas percebi que ele ficou triste. Não queria ir embora. PESQUISADORA: Ele chegou a falar alguma coisa pra você? SRA. HARU: Não. Ele não falou nada.

Depois de alguns anos fora do país, os pais dekasseguis, ao chegarem ao Brasil, se veem acompanhados pelos filhos; não estão mais sós. Surgem outros tipos de preocupações, que até então não existiam. Os pais, angustiados pela nova mudança, passam a se questionar o tempo todo sobre como proceder no Brasil, sem dispor de respostas plausíveis que possam aliviar suas ansiedades: como farão a escolha da escola para as crianças? Dará certo o comércio/ emprego no Brasil? Como fazer as crianças se adaptarem/readaptarem ao país?

De acordo com o relato do senhor Ito, montar uma empresa no Brasil é muito complicado; numa visita anterior ao Brasil com a esposa e a filha Eiko, ainda de colo, pesquisaram um imóvel comercial, que na época seria um bom investimento. Retornaram para o Japão e permaneceram por mais tempo do que o previsto, e, nesse 
atual retorno ao Brasil, perceberam que o mercado ficou saturado e moderno e que seria difícil conseguir acompanhar e ganhar espaço comercial.

Realmente sentimos que a gente tinha algum potencial para brigar por isso, só precisava ter capital. Vamos retornar de novo? Era para dois anos e acabou ficando para cinco. [...] Tem muitas coisas que não são contáveis. Existem fatores e fatores no Brasil que fogem do nosso conhecimento contável. Construir uma obra que "ele" acabou consumindo todas as nossas economias. Você iniciou, ou você termina ou você termina! Porque se você não terminar, você não consegue trabalhar [...] Conseguimos atingir até um certo ponto e a partir disso vê se dá certo. Claro, um dia a gente ia conseguir chegar nesse patamar que estava e dai continuar. Estamos quebrando a cabeça sim. Mas desistir? O que move é aquela esperança. Acreditar? Não tem outro caminho mais. Já foi. A última seria assim o fator cruel assim. Talvez fator assim de extremo. Seria entregar o prédio para a locação. Que não seria interessante para a gente. Depois de tanto tempo. É um projeto que tem mais de dez anos. Então, eu acho assim, ou tenta. De qualquer maneira tem que tentar, porque se não você não, vai ficar sem saber. Fica aquela incógnita. No último caso seria se realmente falar assim: "Não tem jeito”. Então, a gente desiste. E passa para a locação.

As dificuldades da família são inúmeras diante do velho e novo mundo em que se vive. A família passa pelo processo de separação e perdas ao deixar a terra oriental, com a necessidade de renascer ou nascer no Brasil. Esses pais sofrem emocionalmente com essa situação, ficam conturbados com a volta, se sentem sozinhos e sem direção diante dessa nova realidade. Sem ter onde procurar ajuda, onde ter uma orientação, acabam sofrendo desamparo emocional.

Os pais das crianças, ao tomarem conhecimento do nosso trabalho, por meio do Nikkei Clube de Marília, procuraram-nos de forma espontânea para participar da pesquisa. Diante dos fatos, os pais vêm em busca de ajuda, pois vivem um desamparo emocional, procuram respostas para as suas perguntas, querem compreender todo 
esse processo de adaptação/readaptação no país, principalmente no que diz respeito às suas atitudes e às dificuldades dos filhos.

Realmente, fazer parte do mundo japonês não deve ser fácil, mesmo tendo descendência nipônica. $\mathrm{O}$ imigrante, ao chegar a outro país, precisa lidar com o processo de adaptação, que também não difere do processo de readaptação ao seu país de origem. Os imigrantes se deparam com novos jeitos de ser do nativo. Aparecem novos sentimentos, o estranhamento, o diferente diante do outro; surgem também dúvidas quanto a se sua própria presença naquele lugar é bem-vinda ou não. Para a senhora Haru, os japoneses são um povo frio. Essa frieza dos japoneses sentida pela senhora Haru mostra a distância entre os dois mundos, o sentimento de rejeição e a falta do calor humano. Nesse momento, distante de todos, a senhora Haru se vê sozinha e desamparada emocionalmente.

Lá do Japão é mais a frieza dos japoneses. Você sente logo que você chega. Que, vamos dizer, se eles realmente te "aceitou", porque você não sabe se eles realmente te aceitaram ou não. Eles podem falar, te elogiar. Eles são fechados. Até eles te aceitarem. E olha lá! Mas no fundo, no fundo, não te aceitaram. Depois de muitos anos que vão se passando a gente vai vendo isso. Logo no início a gente acha isso: Ah não, já aceitou. Porque aqui no Brasil é assim. Todo mundo é tão assim. Mas não. O japonês não aceita. Ele tem essa cabeça. É essa cabeça. Sim é sim, e não é não. Então, para eles não tem meio-termo. Eles não são flexíveis. Então eu, pelo menos, sofri muito. Mas de resto, o serviço acabou achando fácil. Mas acho que o meu filho deve ter sofrido um pouco com adaptação, apesar dele não falar na época.

Diante dessa nova mudança tão radical, a senhora Haru faz do tempo o seu aliado no processo de readaptação ao Brasil. Diante da necessidade do tempo para lidar com essa nova situação, afirma que "tudo é passageiro".

Eu tento pensar que tudo é passageiro, né? Então, nós estamos ainda numa fase de adaptação. Como a gente foi para um lugar de 
país de Primeiro Mundo, lá tudo tem as coisas. Nós voltamos aonde? No Brasil, que ainda está em desenvolvimento. Tem que colocar isso na cabeça. Vai ser tudo muito mais difícil no início, até a gente acostumar. Tudo é uma questão da gente acostumar. Com um tempo a gente vai, né? Como que se diz? Superando tudo isso, né?

\section{Brasil/língua: dificuldades de adaptação em família}

As primeiras dificuldades de adaptação/readaptação foram percebidas pelos pais de Eiko e Letícia no retorno ao Brasil, no que diz respeito ao fator idade das crianças quando do momento da migração.

Com certeza! O processo de adaptação no Japão e no Brasil devido à idade. Acho que o processo de adaptação foi mais acentuado, a dificuldade maior foi aqui no Brasil do que no Japão devido à idade. Ela foi com 3 anos e retornou já estava com 10. Então, essa questão de como ela foi muito pequena para lá, a adaptação ficou até mais fácil e a aceitação foi bem melhor do que agora. [...] O retorno é engraçado. Assim, a questão da idade realmente pega bastante no processo de adaptação. Nossa filha caçula melhor, ela foi menorzinha. Ela foi de colo, com 6 meses, e voltou agora com 6, 7 anos. O processo de adaptação dela foi mais tranquilo. Então essa questão idade pega bastante.

Os pais consideram o fator idade da criança imigrante relevante para a adaptação ao novo meio. Quando se deslocam bebês ou crianças menores para outros lugares ou países, parece que estes assimilam mais facilmente a nova vida.

$\mathrm{Na}$ opinião dos pais, Eiko teve muito mais dificuldades na chegada ao Brasil por causa do fator idade do que a irmã Letícia, que chegou menorzinha. Quando voltaram ao Brasil, Eiko tinha quase 10 anos de idade, e Letícia, 7. Além do fator idade, temos que levar em conta o grau de escolaridade dessas crianças quando migraram. Eiko alfabetizou-se na língua japonesa e concluiu a $3^{\text {a }}$ série no Japão, 
iniciando a $4^{\mathrm{a}}$ série do ensino fundamental. Enquanto isso, Letícia, aos 6 anos, cursou a metade da $1^{a}$ série no Japão e retornou aos 7 anos de idade para o Brasil. Goro chegou aos 9 anos de idade ao Brasil, tendo cursado no Japão até a $2^{a}$ série do ensino fundamental. Será que o fator idade pode intensificar ou não o desamparo emocional dessas crianças (e)imigrantes?

Outro entrave vivenciado pelas duas famílias foi a dificuldade de aprendizado da língua portuguesa por parte dos filhos, e talvez a principal problemática na chegada dessas crianças ao Brasil. As três crianças participantes da pesquisa chegaram ao Brasil sem saber o idioma português.

O desamparo emocional vivido pelas três crianças que não sabiam a língua portuguesa ao chegar ao Brasil reflete-se no sentimento de perda do conhecimento da única cultura que tiveram até então, a perda da própria língua, que traz conhecimentos abstratos e promove um trânsito entre os dois mundos, do emocional (interno) e da realidade (externa). As crianças, ao perderem a língua japonesa, passam a se sentir "estrangeiras" dentro do próprio lar.

PESQUISADORA: Vocês conversavam em português dentro de casa com elas no Japão? SRA. NATSU: Só japonês.

Os pais, o senhor Ito e a senhora Natsu, logo que chegaram ao Brasil, proibiram o uso da língua japonesa em casa e passaram a fazer uso somente da língua portuguesa com as filhas, idioma até então desconhecido por elas. Eles lhes tiraram qualquer tipo de referência japonesa. Durante seis meses, Eiko e Letícia, filhas de dekasseguis, tiveram que renascer no antigo e novo mundo, o Brasil.

O emocional é difícil trabalhar, porque como ela ficou cinco anos estudando lá, voltou para cá não dominava a língua. Inicialmente teve um problema com a língua, a dificuldade de comunicação da leitura de texto e acompanhamento da matéria, a língua portuguesa. Mas os métodos de adaptação foram um pouco drásticos. Tentamos inicialmente um ponto inicial: forçar o português de tudo qual jeito. Foi forte, foi 
brusco, de tudo que ela tinha aprendido na cultura dela, tudo que ela levava e vivia simplesmente jogar [...] Inicialmente foi feito um tipo de uma coisa, vamos falar assim: de cortar a utilização do poder, de cortar, por exemplo, a língua japonesa, cortar desenhos, cortar, tentar tirar um pouco. Isso foi muito drástico, foi uma revolta muito grande e não estava dando. [...] [Foi] logo no início. Na verdade ela tinha excesso de dados, tinha aula particular, a gente ficava todos os dias até sete e oito horas da noite estudando. Passava o dia inteiro estudando e contando um para o outro: A língua portuguesa, não sei! Então, cortamos todas as regalias. Acaba indo, naturalmente, ela acaba indo para a língua japonesa. Forçamos bastante nesse quesito, mas não houve resultado positivo. Então, era muito, não aceitava. Chorava muito. Então, para aceitar estava muito difícil.

Os pais de Eiko e Letícia não puderam considerar a existência de um mundo japonês internalizado pelas filhas, desprezando-o e não permitindo o acesso das crianças à cultura japonesa. Como se suas filhas tivessem chegado ao Brasil vazias. Os sentimentos de vazio e o de não saber acabaram gerando o sentimento de impotência nessas crianças. A exigência externa era de que construíssem de forma rápida um novo mundo dentro de si, como se todos os seus conhecimentos sobre o velho mundo não servissem mais para essa nova realidade. Portanto, teriam que assimilar ou introjetar um Brasil dentro de si, sem ter "um tempo" para processar todas essas novas informações. As filhas de dekasseguis passam a se sentir recém-nascidas, sem poder recorrer aos pais para um amparo psíquico, e sem dispor da língua japonesa, a qual consideravam "familiar". Assim, vivem o desamparo psíquico dentro do próprio lar. Elas tiveram que conviver com outra língua, a portuguesa, ou seja, uma língua estrangeira, considerada "estranha". No Japão os pais e as filhas falavam a mesma língua, a japonesa, diferentemente do que ocorre no Brasil, quando passam a falar línguas diferentes.

No trecho seguinte, o relato do senhor Ito sobre sua filha Eiko querer falar a língua japonesa: 
Até hoje fala que quer falar japonês. Fantástico assim! Fico muito triste quando vejo as notas dela. Realmente o primeiro ano de adaptação, o segundo ano ela passou? Claro que não passou. Depois de muita conversa com a diretoria da escola... Esse ano, não sei como vai ser. Está muito difícil, mas é uma coisa que ao longo do tempo para aprender. Essa parte dela pulou. Praticamente ela pulou o primário inteiro, então a adaptação, a língua é meio complicada, isso daí. Eu falo assim, ela tem capacidade. Uma capacidade enorme, porque na língua japonesa, eu gostaria que fosse no português, mas no japonês. Ela fez um teste de proficiência há um ou dois anos atrás, ela tirou a pontuação máxima.

Apesar de os anos terem passado, a língua japonesa continua viva nessas crianças descendentes de japoneses que passaram parte da infância no Japão. A língua de um país é também um representante simbólico e cultural de uma nação. O fato é que Eiko chegou ao Brasil já alfabetizada na língua japonesa, diferentemente da sua irmã Letícia, que foi alfabetizada no Brasil.

No Japão, na casa da senhora Haru, a língua falada dentro de casa era a japonesa. Argumenta a senhora Haru que essa escolha pela língua japonesa foi feita com a intenção de evitar que seu filho Goro sofresse na creche. A mãe se preocupava com o desenvolvimento escolar dele na escola japonesa, por ela não ser uma japonesa nata. Assim, justifica que o seu filho também já poderia levar para a escola alguns conhecimentos sobre as palavras e sentidos do mundo nipônico, que ela mesma lhe ensinava. Portanto, a criança não chegaria completamente vazia na escola japonesa, já estaria abastecida de alguns recursos de mundo que a própria mãe lhe interpretara e que o protegeriam de um desamparo emocional.

[Falávamos] Japonês. Japonês, porque assim não sofresse na creche. Porque a criança de japonês, os japoneses eles ensinam já desde pequeno, já ler mais ou menos. Dá uma noção para a criança do que é isso, do que é aquilo, da fruta, cor, tudo, tudo lá as crianças lá já sabem muita coisa, né? Os tipos de pássaros, até às vezes uma criança de 4 ou 5 anos já sabe. Eu não queria que ele sofresse, como vou lhe dizer, uma certa, 
pode ser, que ele não soubesse nada. Então, comecei ensinar o japonês, ensinar as frutas para ele, os animais, para ele começar a ter uma noção do japonês.

As escolas japonesas, além da estrutura física melhor do que as escolas brasileiras, oferecem mais qualidade de ensino. A criança, ao estudar na escola japonesa pública, apenas tem um custo mensal de transporte e alimentação, num valor muito abaixo das demais escolas brasileiras que são particulares. Portanto, a senhora Haru era favorecida pela prefeitura da cidade e tinha alguns benefícios por criar seu filho sozinha no país.

Ao perguntar para a senhora Haru se a criança fala a língua portuguesa, ela responde:

Ele não fala muito o português. Muito ruim o sotaque dele. Quando ele fala, inverte tudo. [...] O português ele compreende e na hora de responder é tudo o japonês praticamente. E comigo, não sei como ele sabe que eu entendo, ele não faz um menor esforço em aprender ou em responder em português. Já espontaneamente sem querer está falando só japonês comigo. Agora, com o primo que, no caso dele, está aqui e não sabe japonês, ele tenta. Vamos jogar game? Game, pega o controle. Ele inverte, mas ele tenta, se esforça e tenta se comunicar. Os dois se dão bem. Eles estão lá brincando. Eu pensei que fosse ter essa dificuldade: será que na escola ele vai se adaptar? Por ele ser essa criança meio retraída. Ele chegou com o primo e já foi conversando. E com as primas, não tem jeito, as primas também são japonesas. Tem mais facilidade, né?

Nesse relato da senhora Haru, no diálogo com seu filho, a língua japonesa é usada para se comunicar com a mãe, ao passo que, com os primos brasileiros, Goro se esforça para se comunicar no idioma português, sem ter tempo para mediar esse trânsito tão radical de um lugar para o outro. 


\section{Cultura: Brasil versus Japão}

A cultura brasileira e a japonesa são apontadas pelos pais das crianças como culturas muito distintas. A mãe Natsu relata que as filhas perceberam que eram diferentes das crianças brasileiras. Portanto, elas falam das dificuldades de construir vínculos de amizades, como se não pudessem se identificar com a criança brasileira. Além das crianças brasileiras terem comportamentos diferentes das crianças nipônicas, Eiko e Letícia destacam o comportamento dos professores na sala de aula, o qual difere do professor japonês. Estamos diante de dois contrastes: a obediência do povo japonês e a desobediência ou liberdade dos alunos brasileiros na sala de aula.

Ela fala que as crianças daqui são bem diferentes, para fazer amizade é mais difícil. Não sei o colégio também. [...] [Ela estuda] no "B" [particular]. Tem muita dificuldade para fazer amizade aí. [...] É bem diferente. Apesar de criança [...] os adultos e os professores falam assim. Porque lá no Japão os professores deixam a classe, faz isso e eles fazem. Agora aqui, ela fala: "Nossa! A professora tem que ficar gritando para eles obedecerem!". Não sei o porquê que acontece isso. Aqui é diferente.

O Japão é um país que vive de forma hierárquica, ou seja, todos têm que respeitar o líder ou a pessoa mais velha dentro da hierarquia. O senhor Ito diz que essas diferenças são sentidas também na chegada ao Japão. Relata que os japoneses se submetem e idolatram o imperador. Entretanto, no Brasil, os brasileiros parecem não saber viver com a própria liberdade.

[...] na verdade é aquela submissão, até que eles mantêm o sistema de idolatrar o imperador. Por exemplo, aqui no Brasil é tão democrático, é tão, que chega a ser democrático demais. Todo mundo tem a liberdade, tem o excesso de liberdade, que acaba se tornando... De certa forma confunde, fica, tem... As pessoas têm liberdade demais até. Então, talvez seja um choque. [...] Então é diferente. Infelizmente é diferente. Lá a pessoa fala, se é um professor, independente se é um professor do 
que for, quando se fala que é um professor, um mestre, impõe respeito, e aqui não. Então existe essa... Aliás, então é a grande diferença, é um choque na verdade até para os adultos, pra gente também. [...] Infelizmente no nosso país não tem nada que faça, só tem a Copa do Mundo. Mas criar um certo patriotismo... Mas isso é, realmente faz a diferença da cultura. No caso delas é essa liberdade, né? Às vezes acaba atrapalhando, porque os amigos ou as amiguinhas fazem o que interessa fazer. $\mathrm{Na}$ verdade então existem leis de jogo de interesse, não existe o ideal. Seria comunitário.

O senso de sociedade coletiva faz parte do mundo japonês. $\mathrm{O}$ senhor Ito diz que somente se vê o patriotismo do brasileiro diante de uma Copa do Mundo, diferentemente dos japoneses, que visam ao senso coletivo no dia a dia para viver em sociedade. Portanto, os professores japoneses, sendo transformadores sociais, são denominados mestres, figuras respeitadas por todos no país.

Em contato com a realidade brasileira, a criança Goro deixa as suas fantasias de um Brasil ruim e conhece o Brasil real. A diferença é nítida em relação ao espaço territorial entre os dois países, algo percebido logo na chegada ao Brasil. A maioria das casas brasileiras tem quintais, ao passo que em todo o Japão falta espaço geográfico. Anteriormente, no Japão, a criança era discriminada pela sua aparência física, por ter uma "imagem meio japonesa". Ao retornar para o Brasil, percebe a diversidade racial, não se sentindo diferente dos brasileiros em relação à sua própria imagem.

Ele tinha uma visão muito ruim do Brasil. Ele achava que o Brasil era ruim. Quando ele chegou aqui, ele foi na casa da minha irmã, ele viu como é que é. Tem espaço, dá para brincar fora. Começou a ver que não era aquela coisa que ele estava imaginando, né? Agora, ele está aceitando. Até que aqui as pessoas são diversas raças, você encontra japonês, encontra de tudo aqui. Então, ele não sentiu essa diferença assim, né? Também ele está morando junto com a minha mãe. Acho que isso tem um pouco mais de segurança. 
A sociedade brasileira é heterogênea, distinta da homogeneidade japonesa. O Brasil é um país mestiço, onde podemos encontrar vários povos do mundo todo.

\section{Escola japonesa e escola brasileira}

\section{Escola japonesa}

A escolha da escola pública japonesa pelos pais de Eiko e Letícia pode ser explicada por vários motivos. Os pais argumentam que as estruturas físicas das escolas japonesas são amplas e os professores são profissionais qualificados, ao contrário das escolas particulares brasileiras no Japão, que não oferecem um espaço adequado para as crianças, além de ter muitos professores sem formação específica nas disciplinas que lecionam.

[...] sabe que, na verdade, no Japão, nós temos escolas particulares entre aspas, que não são bem escolas, são adaptações, improvisações de escolas, mesmo sendo privadas, pagas, com mensalidades e tudo mais. Elas carecem de estruturas, né? E o público lá, o público é até uma coisa de você ficar até assustado, realmente, não só defendendo a questão econômica, mas também a questão de bem-estar mesmo, porque muito se ouvia que isso não era escola, um depósito de criança e não sei o quê. A criança fica o dia inteiro "confinado" e coisa e tal. Então realmente, né? Era muito fraco, em termos de estrutura. De repente não vou desclassificar os profissionais que davam aula lá, mas a estrutura era fraca. Aí optamos por colocar em colégios públicos, em escolas públicas, $e$ muito bem servidas mesmo, realmente. PESQUISADORA: Desde o início? SR. ITO: Desde o início. Foi feito um levantamento eu e ela.

A intenção dos pais de Eiko e Letícia era que as filhas pudessem terminar seus estudos no Japão e, posteriormente, que elas mesmas tomassem a decisão de escolher onde quisessem morar. Em decorrência da situação da crise econômica japonesa, o pai decide retornar 
para o Brasil. Em consequência disso, as crianças interromperam seus estudos no Japão.

Lógico, pensar em voltar, tínhamos. Tínhamos um projeto na verdade, o projeto era até mais longo. É que fatos e fatos ocorrem que acabou mudando todo o nosso projeto, mas dentro daquele momento, daquela fase, falamos assim: "Bom, a intenção era terminar os estudos lá no Japão. Então, pelo projeto inicial a gente previa até ficar mais tempo, muito mais tempo no Japão. De repente, porque não qualificar ela lá, e depois deixar para ela decidir, o que seria melhor seguir?". Mas, infelizmente, em determinados momentos, problemas de crises e outras situações que aconteceram que não era previsível "pegou". $\mathrm{Na}$ verdade era uma coisa que pegou todo mundo, vamos dizer assim, $e$ acabou forçando e mudando todo contexto, aquele projeto, e tive que repensar, calcular, vão ver como vão fazer, recalcular e como resolver a situação.

A escolha pela escola pública japonesa pela mãe de Goro foi motivada pela questão financeira, por seu custo menor em relação à escola brasileira no Japão. A senhora Haru, por ser uma mulher divorciada e com um filho pequeno na época em que chegou ao Japão, passou a receber auxílio financeiro da prefeitura de sua cidade para manter a criança. Em seu relato, diz que as mensalidades das escolas brasileiras eram altas e sentia dúvidas quanto ao tipo de tratamento dessas crianças nas creches brasileiras.

[...] [A escolha foi] mais pela parte financeira. Porque no início a gente veio, a minha mãe tava com esse trabalho só de 8 horas, não ganhava muito e não dava para colocar numa creche brasileira. A creche brasileira é mais do que o dobro de que uma creche japonesa. [...] [A creche japonesa] tem que pagar, mas é baixo. No caso, como era divorciada, então o governo me ajudava e a prefeitura também me ajudava. Eu pagava menos na creche; as consultas médicas, tanto a minha como a dele voltavam. Então, eu tinha ajuda de custo. Então, isso me ajudava bastante. Por isso, na creche brasileira, se eu fosse colocar, era aquele 
valor, independente se eu sou divorciada, não sou, isso ou aquilo, posso ter os meus problemas, mas isso não tem nada a ver. Era aquele valor, era aquele valor. Era muito caro.

\section{Escola brasileira}

Os pais, ao retornarem para o Brasil, optam por colocar suas filhas Eiko e Letícia numa escola particular, diferentemente da escolha no Japão, onde optaram por escolas públicas japonesas.

Quando voltamos para cá, para não sentir tanto assim, falei: "Vamos colocar em uma instituição particular aqui". "Devido aqui" as condições do Brasil se invertem... Quase as melhores. Se não for a segunda melhor, é a primeira melhor e tem uma estrutura fantástica. Para não sentir tanto esse choque, choque tanto cultural dos receios das crianças... Queira ou não queira, não quero desqualificar as crianças dizendo assim: "Quanto maior ou menor a sua renda, ou coisas, pode ter uma educação familiar um pouco mais precária". Mas é lógico, tem tanto assim, pelo que eu imaginava. Então, tanto em termos de estrutura também, porque lá ela tinha aula de música e tudo mais, né? Espera aí, vou pôr numa escola à altura para não sentir esse choque tão grande, né? Mas o choque não é muitas vezes só essa questão do ambiente também, um pouco é o emocional.

Diante de tantas dificuldades de retorno ao Brasil vividas pela família da irmã Natsu, a senhora Haru decide matricular o filho Goro em uma escola de idiomas para aprender a língua portuguesa, antes de ingressar diretamente na escola de ensino fundamental. Portanto, a criança, ao ingressar na escola de ensino fundamental, já estaria alfabetizada.

Ainda não [está frequentando a escola]. Ainda não porque, como nós chegamos em maio, ele vai perder praticamente esse meio ano inteiro estudando, né? Não vai aprender nada. Então, eu falei pra ele: "Vamos entrar e estudar no Kumon? Para fazer a língua portuguesa e 
aprender um pouquinho, porque o ano que vem já pega a escola o ano inteiro." Tanto que a professora do Kumon falou a mesma coisa para mim: "Não é bom você colocar na escola agora. Vai pagar, e pagar, e seu filho vai ser reprovado. Então, compensa mais você o quê? Dar mais uma assistência agora na língua portuguesa. Adiantar ele, para ver se o ano que vem ele consegue se firmar e seguir o ano que ele está".

A senhora Haru, ao contrário de sua irmã Natsu, buscou preparar a criança no mundo das letras. Não queria que seu filho chegasse sem o mínimo de conhecimento na língua portuguesa. A não compreensão da língua escrita e falada, ao ingressar na escola, numa classe já alfabetizada e estando em outro ritmo, pode trazer sérias consequências para a criança filha de dekasseguis. Acaba surgindo nessas crianças o sentimento de impotência diante da própria vida, gerando nela resistências para aprender o novo idioma, isolando-a e, além disso, dificultando a construção de novos vínculos.

\section{Retorno para o Japão}

As filhas do senhor Ito e da senhora Natsu sonham com a volta para o Japão. Na citação a seguir, o pai fala da filha Eiko:

Hoje, ela fala muito de voltar para o Japão, que a terra dela é lá e coisa e tal. Eu falo: "Se vai voltar, então estuda". O japonês está indo bem, o problema é o português. Pensa então, tem que estudar o português. Tem uma amiga dela que está fazendo uma faculdade agora e está tentando uma bolsa de estudos no Japão. Eu falo: "Você viu! Ela está fazendo uma faculdade. Para fazer uma faculdade, para você ingressar lá, primeiro tem que aprender o português, sair bem nos estudos de português e entrar na faculdade. No Brasil também pode cursar uma universidade lá. Você precisa dos dois”. A gente está buscando realmente, porque talvez seja, é um caminho que já teve, e é uma coisa que leve ela passar, não precisa estudar. Verdade que isso realmente não é fácil. É difícil. 
A criança Letícia, apesar de sociável, deseja, segundo a mãe (senhora Natsu), retornar para o Japão.

Eu não sei o que é, mas ela é bem diferente, essa nossa caçula. Porque é bem sociável. O jeito dela é bem diferente. A mais velha é mais retraída. Agora a caçula não é, conversa com todo mundo. Da classe dela, ela é amiga de todo mundo. Ela consegue fazer amizade fácil. Também é diferente. [...] [A caçula] tinha bastante [problema] [...]. Foi um pouco difícil. Só que talvez ela "consegue" se soltar. Ela não segura para ela. Acabou ficando bom para ela. Só que ainda fala de voltar para o Japão. [A caçula] fala que gosta mais de lá.

Novamente nos deparamos com o fator idade da criança no ato da sua migração. Então, podemos concluir que, quanto menor a idade da criança (e)imigrante ao chegar a outro país, mais facilidade terá de construir novos vínculos e de se integrar à nova cultura?

\section{Sentimento de culpa dos pais}

No relato do senhor Ito, aparecem alguns sentimentos, como a dúvida, a impotência por não ter conseguido fazer mais por suas filhas, o egoísmo por ter resolvido tudo sozinho e, enfim, o sentimento de culpa por ter não ter dado a opção de escolha para as filhas decidirem sobre o retorno ao Brasil.

Assim, daqui para frente fico imaginando isso, pensando assim. $\mathrm{Na}$ verdade os pais "é" uma coisa assim que não tinha prestado atenção, a gente vive em prol dos filhos. Até fico comentando com ela [esposa]: "Será que a gente não deveria ter pegado, se sacrificado?". Nem se fosse para mim, sacrificar o ideal alguma coisa. O nosso propósito era montar alguma empresa aqui, e tudo mais, ser sucedido e coisa e tal. De repente, se era para o bem delas, teria que ser empregado pelo resto da minha vida. Mas não imagina assim. Eu imaginei uma forma mais fácil e fui até um pouco egoísta, pensando na minha questão e não na 
questão dela. Só que fui perceber aqui. Já era bem tarde. Fica um pouco complicado.

O senhor Ito continua:

Então fica aquela questão. Aquele valo. Na verdade, falo assim: "Você largaria em prol da felicidade das suas filhas? Você largaria de tudo? Voltaria a viver, sacrificaria a sua vida?". Falo assim, pra felicidade delas. Acho que sim. Viveria, sacrificaria, mas a situação não permite isso. [...] Agora entrou no contexto que a gente percebeu, que por mais que a gente tente preparar tudo e dizer: "Vão voltar pra lá?". Tem gente que voltou. Conheço pessoas daqui mesmo, que vierame tentaram o mesmo caminho que a gente. Teve a crise. Teve os problemas lá. A coisa ficou no mundo. Então, retornaram. Por questão dessas dificuldades de adaptação dos filhos, retornaram para o Japão. Acabaram retornando para o Japão. Agora, entendi. Compreendi. Muitas vezes comentei com ela: "Se tivesse uma condição boa lá, a gente retornaria, até se sacrificaria a vida, mas é por essa opção". Você realmente quer dar o melhor para eles. É duro, né? Às vezes a melhor coisa não é nem ser a melhor escola. É duro, né? O país inteiro. Todas as questões. Às vezes ficam se comentando, comentando, porque tem tantos buracos na rua? Por que tem quebra-mola? É complicado, né! Por que, né? Até eu às vezes fico pensando: "Por que tem tantos encargos? Por que tantos impostos?". Você vai para exterior, existem outros lugares que realmente... Você foi lá e voltou, [...] você viu o valor de gasolina mais barata e está tão cara aqui. Lá não se produz uma gota. Você fica assim.

Diante de tantas dificuldades, os pais não conseguem compreender o porquê da revolta das filhas, sobretudo da mais velha, que diz que os amigos estavam esquecendo-a. Novamente, os pais se deparam com o sentimento de impotência diante do sofrimento emocional das filhas.

A expressão de revolta dessas crianças filhas de dekasseguis é uma forma de lidar com a dor de tantas perdas em tão pouco tempo em suas vidas. Elas não perderam somente a língua, mas também toda 
uma convivência cultural, separações de vínculos de amizades. Portanto, passaram a viver privadas do mundo japonês.

Complicado, né? Na verdade, não tínhamos o que fazer. Dentro do possível é conversa, é conversar, né? É muito complicado assim, porque realmente não está entendendo o porquê elas se revoltaram tanto. Foi difícil. Na verdade a ficha foi cair muito tempo depois, né? Ela falou que chorava bastante e sonhava. "São difíceis" contar sentimentos. $\mathrm{Na}$ verdade, assim, ela dormia e, coitada, ela sonhava, e aquilo era tão forte, tão forte para ela, que mexia. Quando ela acordava, amiguinhos. Tem um fato que ela contou para gente e que me marcou. Eu fiquei muito sentido. Ela me falou que os amigos estavam esquecendo. Que todo mundo estava "esquecendo dela".

Os pais tentaram fazer contato com a escola, amigos, por meio de cartas, porém nunca obtiveram uma resposta. Nas escolas japonesas é comum os professores serem transferidos para outros lugares. A atitude desses pais é mais um pedido de ajuda, ou seja, um pedido de socorro para suas filhas. De certa forma, eles tentam resgatar algum vínculo do passado, sem ter êxito algum.

Mandamos carta para a escola e não voltou. Eu não consigo fazer nada. Como vou fazer algum amigo para ela? Como vou fazer algum contato com professor? [...] Não houve retorno. É complicado também, porque lá no Japão os professores mudam muito. Eles não ficam estabilizados numa escola só. De tempos em tempos eles estão mudando de lugar. É um aperfeiçoamento constante. Eles têm até aulas na faculdade. Então, aquela professora e aquele professor poderiam não estar mais lá. A carta endereçada foi para lá, mas lá não tem o professor. Não tem esse. De repente não conseguiu um outro contato. Ela falou que sonhava. É duro essa questão de sentimento.

Essas crianças filhas de dekasseguis, quando chegam ao Brasil, temem ser esquecidas pelos seus professores e amigos que tinham no Japão. Portanto, elas também têm que lidar com o sentimento de 
abandono. Essas fantasias de perder o que conquistaram no lugar onde moraram acabam refletidas nos seus sonhos e também nas dificuldades de adaptação/readaptação no Brasil. De forma inconsciente, surgem as resistências em aprender o novo idioma, pois a criança teme esquecer o que aprendeu no país em que morou.

Por mais que a gente fale e fale. A gente explica e conversa bastante com ela. Realmente aqui é diferente. Ela tem que se adaptar. Por mais que a gente fale, acho que o sentimento não acompanha. [...] Ela não aceitou da gente morar aqui. Ela acha que a gente tem que voltar para lá. PESQUiSAdora: Ela fala isso claramente? Ela fala em português ou em japonês? SRA. NATSU: Em japonês. PESQUISADORA: E o português dela, como está? SR. ITO: O português dela está bem gradativo.

A criança Eiko manifesta a sua insatisfação e as dificuldades de adaptação/readaptação em morar no Brasil. O seu desejo é de voltar para o Japão. A mãe, a senhora Natsu, reforça que a filha Eiko "tem que se adaptar", como se a adaptação no país fosse a única solução para acabar com o sofrimento da criança.

\section{Família/identidade}

A questão da identidade das filhas era motivo de discussão na família. As filhas de dekasseguis Eiko e Letícia se consideravam japonesas em virtude de sua aparência física, e elas questionavam o porquê de os pais não serem japoneses. Essas crianças estavam identificadas com a cultura japonesa, e o brasileiro, para elas, era chamado de estrangeiro ou gaijin, por ter costumes e hábitos diferentes daqueles com os quais já estavam acostumadas na sociedade nipônica. As crianças não se consideravam estrangeiras dentro do Japão.

Podemos pensar numa identidade híbrida dessas crianças? Afinal, estamos falando de duas experiências culturais distintas, a japonesa e a brasileira, dessas crianças imigrantes. 
Na verdade existe um problema de choque cultural pelo seguinte: a gente, engraçado, elas consideram japonesas. Olha só que coisa engraçada! Ela, no registro de nascimento dela, ela nasceu no Japão. Está lá Matsumoto [nome da cidade japonesa], tudo direitinho. É uma coisa engraçada assim. Aparência física de nikkei, nikkei, ela se achava assim. Quando ela entrou na escola pública lá e tudo mais, na verdade fala assim: "Por que papai e mamãe não é japonês?". Querendo ou não querendo, eu não sei se é porque, de certa forma, existe um certo preconceito. "Existe" todos os países, existe um certo... o patriotismo, que é o tal gaijin de pessoas de fora. A sociedade é formada e educada de um certo jeito. Chega uma pessoa e ela não conhece essa formação e essa educação. Ela faz de hábitos diferentes, causa certo... como que se fala, chama a atenção. De chamar atenção e muitas vezes chama atenção infelizmente pelo lado negativo. Vamos dizer assim: no Brasil muitos jovens, o brasileiro não vai fazer a limpeza. Eu fui criado no Brasil, onde sempre teve servente na escola. Quem faz a limpeza é a servente. Existe toda uma cultura enraizada em cima disso. Sem querer resolver, é uma cultura minha. Só que lá não. Tem que limpar. Lá não tem servente e quem que limpa é o próprio aluno. De repente nisso, nesse contexto acaba se criando uma atenção, uma atenção negativa, porque se fosse positiva... De repente não, olha que bacana! Sempre causa negativo. Aícria-se aquela questão de racismo. Moleque, você é brasileiro. Eu ouvia muito isso! Devido à forma física de ser nissei, achava que era japonesa. A minha filha começou a perguntar para mim: o que a gente era? Brasileiro. Por quê?

\section{E continua:}

Ela tinha uma certa vergonha. Um certo preconceito. Não que seja preconceito. O preconceito que nem lhe expliquei agora. Por que ocorre esse preconceito? Devido a isso, ela: "Eu sou japonesa”. É engraçado ela ouvir dizer que amiguinhos dela "chegou", que eram brasileiros. Fala que é gaijin. Que gaijin o que, minha filha? Você é brasileira. Não é, mamãe. Não é, por quê? Tenho aparência de japonês. Quando a gente fala português, ela queria que a gente fosse japonês. Da melhor 
maneira possivel, ela fala: "Fala que é japonês!”. [...] Isso lá no Japão. Porque lá, ela tinha um certo constrangimento por ser brasileira. Minha filha, você é brasileira. Como os amiguinhos nunca estavam com essa aparência... Não só aparência, mas nossos costumes. Tenho uma avó muito rigorosa. Costumes de nikkei-jin, nissei. Para a gente falar o japonês era simples. Fácil.

A mãe da criança Goro, a senhora Haru, relata que teve muitas dificuldades no Japão por causa da aparência do filho, que é mestiço de brasileiro/japonês. Ela era constantemente questionada pelo seu filho, que se sentia diferente diante das crianças nipônicas em virtude de seus traços físicos. Para a criança, a sua imagem não era inteira, não poderia ser um completo japonês; era como se lhe faltasse sua outra metade.

Tiveram muitas dificuldades, hein? Inclusive já pela aparência do meu filho, por ser mestiço. Ele era mestiço. Então, ele se sentia muito complexado por ele não ter olho puxado. Já começou por aí. Ele ficava me perguntando: "Mamãe, por que eu não tenho o olho puxado?". Pra ele, os japoneses eram bonitos e ele era feio. Eu falava para ele: "Nossa, meu filho! Você está pensando diferente, porque os japoneses querem ser ocidentais". Tanto é que lá os homens e as mulheres eles fazem o possível para terem os olhos grandes, o cabelo enrolado. Quer parecer com ele. Eu falei para ele: "Quer parecer com você", mas ele não aceitava isso. Até hoje ele fala isso, que bonito é o japonês. Que ele é feio. Já começou por aí. Mas tirando essas coisas também, costumes, né? Os costumes dos japoneses... eles são mais frios. Então, principalmente os pais das crianças, a gente sente que a gente nunca vai se igualar a eles. Por mais que você saiba falar japonês, por mais que você tente entrar na sociedade $e$ frequentar, a gente nunca vai ser igual a eles. Eles são sempre superiores a nós, então fica difícil. Eles cultivam isso nas crianças também. Então, por isso começou a criar um certo complexo de inferioridade, onde gerou um pouco de insegurança nele. Percebia isso nele. 
A situação vivida pela criança Goro provoca nele um sofrimento emocional, por ser diferente das demais crianças. A nacionalidade brasileira é vista pela criança como a causa dessa diferença.

[...] Ele já começou a falar pela aparência. Ele começava sempre a se achar menos que os outros. Falava: "Fulano de tal é assim, mas eu não consegui". Ele sempre vinha falando pra mim: "Mamãe, eu não vou conseguir! Eu não consigo, porque é difícil”. Ele sempre colocava muitos empecilhos e ele não conseguia. Aí, ele falava até que "porque eu sou brasileiro". Eu falava não, né? Que isso não tem nada a ver, todo mundo consegue. Ele falava: "Não, mas é porque sou brasileiro". Ele colocou isso na cabeça dele.

Apesar de Goro chamar a atenção das crianças japonesas pela diferença física, aguçava entre elas a curiosidade pelo estranho. A criança Goro se afastava das demais crianças japonesas por não ser igual a elas e por ser alvo de brincadeiras maldosas que ele mesmo não aceitava. Neste trecho, relatado pela sua mãe, Goro nega completamente a identidade brasileira.

Os coleguinhas dele, no primeiro ano, até queriam chegar e saber mais dele. Só que ele acabava afastando as crianças. As crianças queriam: "Como que é o Brasil? Como se fala isso em português?". Mas ele não queria, ele detestava falar sobre o Brasil porque pra ele, ele não quer ser brasileiro, não aceitou o Brasil. Então, ele falava assim: “Eu não sou brasileiro! Eu sou japonês!”, ele falava pra mim. Por ele ter sido criado lá e crescido lá, né? [...] Hoje, ele fala que é brasileiro. Ele até fala que é brasileiro. Mas quando você vê esses jogos de games que precisam colocar a bandeira do país, ele não coloca a bandeira do Brasil. Você vê que a bandeira é do Japão. Ele escreve o nome dele em japonês... E a bandeirinha dele é japonesa. Eu falo para ele: "Mas a bandeira do Brasil não é essa, né!". Ele fala: "Mas não. Está bom essa". Não faz questão de mudar. Quando eu coloco meu nome e coloco a bandeira do Brasil, ele fala: "Mamãe, por que a mamãe colocou essa bandeira?". Eu falo: "Mas a mamãe não é japonesa. A mamãe é 
brasileira”. Ele fica meio assim, não fala nada. Quando ele vai jogar ou desenhar assim, ele é japonês.

O contato com a nova realidade brasileira, o deslocamento geográfico e espacial do Japão para o Brasil traz uma mudança na fala da criança Goro sobre a sua identidade. Portanto, no Japão, ele queria ser japonês; no Brasil, diz ser brasileiro. Porém, não é o que ele sente quando escolhe a bandeira japonesa no jogo de futebol.

\section{Preconceito/Japão}

Para o senhor Ito, o preconceito é gerado pela falta de conhecimento da cultura do outro. A partir do momento que o imigrante começa a interagir de forma contínua com a cultura do país onde está vivendo, passa a ter uma compreensão cultural entre os diferentes grupos.

[...] a gente pensava que existia um certo preconceito. Não entendia direito a questão do preconceito. Nós somos operários, que coisa chata! Depois que a gente passou a frequentar a escola japonesa, escola pública, "começamos ganhar" a sociedade. Nós que criamos os nossos próprios preconceitos falando que eles são preconceituosos. É uma falta de entender a cultura deles. Você está no local diferente e você tem que "adequar" à cultura deles. Na verdade o homem é assim: como não conhecemos a cultura, fala que é preconceito, preconceito. Não é. É que a gente está fazendo errado. O que rege os costumes, o que rege a educação, a gente não conhecia. Falava que era preconceito. Da escola passamos para biblioteca. Queria deixar de ser operário e pegar um serviço que trabalhava com japoneses. O preconceito estava na gente mesmo, na nossa formação. O que mudou? A partir daí, ela começou a ter contato. Eu também peguei um serviço melhor. Não mais na linha [de produção], era no almoxarifado. 
O preconceito para a senhora Haru foi sentido de imediato no ambiente escolar. O sentimento que surgiu foi o de exclusão e de desprezo por parte dos pais japoneses, na participação da reunião escolar. Ela vivencia o sentimento de "ser invisível" diante do outro, de não poder se fazer presente na condição de imigrante. Justifica que, perante a comunidade japonesa, os brasileiros "não são bem vistos" na cidade e, em decorrência disso, são discriminados.

Então, os professores, eles mesmos já estavam acostumados a lidar com brasileiros. Apesar dos japoneses serem frios e tudo, o tratamento é igual, né? Eles cumprimentam e tudo. Os professores em si, eu não senti diferença, né? Eles tratavam as crianças iguais, mas por parte dos pais que a gente sente essa discriminação. [...] Eles têm [preconceito]. Porque o brasileiro lá no Japão é muito mal visto, né? Já começa pela questão disso. Por causa de poucos que acabam fazendo muitas coisas, acidentes, rouba e isso e aquilo, matam. Então, por causa desses poucos nós somos muito mal vistos. Eles têm medo, têm receio de se aproximar da gente e da gente fazer isso. A cabeça deles ainda é muita fechada. Eles não conhecem muito o Brasil. Então, eles não sabem como que é o país, as pessoas de lá. Então, eles generalizam. Formou essa cabeça, esse pensamento com relação ao brasileiro. Então, é assim. É difícil a gente quebrar isso daí. Só que com a convivência eles sabem que não é bem assim. Na creche não foi tanto. Eu senti mais quando eu coloquei ele na escola. Eu me senti mal. Até pensei: "Será que o meu filho está se sentindo bem?". Porque o primeiro dia que teve a reunião dos pais, eu me senti uma pessoa totalmente diferente. Eles me excluíram assim de uma forma tão visível, que eu me senti mal. [...] Assim, tem muita coisa que tem que participar junto, conversar, né? Eles não perguntaram a minha opinião. Acabou assim: "Ela é brasileira, ela não entende. Pode passar e rodar". Então, pensei que poderia perguntar e chamar, mas nem isso. Eles decidiram: "É assim, é assim". [...] [Morávamos em] Nagano-Ken, a cidade Matsumoto-Shi. Só que lá era uma vila. Que acabou virando cidade de Matsumoto. Lá o pessoal é muito mais fechado. Tem muito idoso. Então, a cabeça mais fechada ainda, a deles. Eles não aceitam muitas coisas, né? Tanto é que a gente fala que é brasileiro, 
tem lugar que eles não dão serviço, né? Por ser brasileiro e fazer muitas coisas erradas. Então, a gente acaba ficando mal visto nisso, né?

Diante da experiência da discriminação vivida pela senhora Haru na escola japonesa, ela passa a se questionar sobre como está o filho Goro na escola. A preocupação da mãe com o filho é se ele está se sentindo bem no ambiente escolar. A criança, ao ser indagada pela mãe, diz que "tudo bem". Porém, se queixa das crianças japonesas que fazem comparações físicas, mostrando que Goro é diferente do japonês nativo.

Mas eu percebia que ele ia para a escola, mas não se sentia muito bem. Ele sempre falava que: "As crianças falam muito do meu cabelo". Que o cabelo dele é enrolado. "Falam que eu sou cabelo enrolado. Ficam me chamando de vários nomes". Comparam que o olho dele é diferente de grande. Então, não tem nada a ver com japonês, e a pele dele é branca e não chega a ser amarela igual os japoneses. Então, ele fala: "Por que sou assim diferente?". Porque seu pai é brasileiro, diferente. Por isso que você é assim. Mas ele não entendia. Acabava não entendendo.

O trabalhador imigrante é visto como "estranho" perante a sociedade em que vive. A marginalização sofrida pelo imigrante traz mudanças de comportamentos em ambas as culturas. Alguns incidentes de roubos, furtos e homicídios que são praticados pelos imigrantes tornam-se, concretamente, alvo de condenação aos olhos dos japoneses. Tudo isso dificulta a aproximação e a formação de vínculos entre ambas as culturas.

A adaptação é a maneira de ajustar-se ao meio onde se vive. $O$ processo de adaptação é uma forma de mudança em que o indivíduo, no contato com o meio, vai se ajustando, se acomodando às necessidades do grupo onde passa a viver.

A adaptação é também um ajuste entre as fantasias e a realidade, tanto dos dekasseguis que chegam ao Japão com uma série de fantasias sobre esse país quanto dos japoneses natos que possuem 
uma série de fantasias sobre o Brasil, os brasileiros e os próprios dekasseguis. As fantasias nem sempre condizem com a realidade e isso exigirá um ajuste nada fácil, especialmente quando se esbarram em imaginações e idealizações bem estabelecidas.

É comum haver preconceitos de ambas as partes, resistências em aceitar uns aos outros e vencer as diferenças. Há também um receio mútuo de perda da identidade: os imigrantes temem perder sua cultura de origem e os nativos, de ter sua cultura modificada pela presença de "estrangeiros", mesmo quando esses "estrangeiros" são, como no caso dos dekasseguis, descendentes de emigrados do próprio país.

\section{Crianças e adolescentes dekasseguis}

\section{Caso Eiko}

\section{Vivência de desamparo de Eiko com os pais}

As crianças acabam percebendo as dificuldades financeiras da família. Fazem comparações entre o país onde viviam e o país onde moram atualmente. A criança (e)imigrante nota que se encontra em outra condição financeira, como Eiko, que constata o menor poder aquisitivo em relação ao de quando morava no Japão. A adolescente comenta que falta dinheiro na família em razão de as instalações comerciais dos pais serem novas na cidade e por eles não terem ainda conquistado um espaço nesse setor que pudesse garantir um retorno financeiro.

[...] Eu parei de ir ao Nikkei. Agora, está um pouco com problema, com dinheiro também. Está complicado. Voltamos agora do Japão, o trabalho não dá. O salário não é bom. A gente estava tentando não sair da escola e não sair do Nikkei. Quando acabar esse ano, vai colocar em outra escola. As pessoas não vêm muito. Não acreditam que o salão, não quer fazer festa no nosso salão. Está um pouco complicado. Os 
salões velhos todo mundo sabe. Dá para acreditar? Nossa loja é novinha. Então é difícil de entrar os clientes que querem fazer a festa. [...] Sinto um pouquinho triste [falando sobre deixar o Nikkei]. Tenho que segurar um pouco. Quando era pequena pedia qualquer coisa e eles compravam, e agora tenho que ajudar um pouquinho. No ano que vem vai colocar novamente no Nikkei, se conseguir. [...] Que não vou conseguir ver o amigo todos os dias. Tem amiga " $Y$ " brasileira que fala japonês $e$ português. Ela tem 18 anos. "R", de 12 anos, nasceu no Japão e sabe português e japonês.

A experiência da angústia familiar do imigrante para conseguir seus próprios recursos financeiros para seu sustento na terra natal é uma batalha enfrentada diariamente. O sonho de Eiko para ficar com a sua turma no Nikkei teve que ser interrompido mais uma vez, por questões financeiras, antes no Japão e agora no Brasil. Anteriormente, no Japão, os seus pais tinham o poder aquisitivo de compra; atualmente, esses pais estão mais empobrecidos, com poucos recursos financeiros, mobilizando em Eiko frustrações e solidariedade com a família.

O sentimento de impotência é vivido não somente pelos pais, mas também por Eiko diante da vida, como se o Brasil, a terra que não escolheu para viver, lhe apresentasse o outro lado, ou seja, o lado difícil da vida.

Além da família de (e)imigrante ter que lidar com o sustento da casa, existem muitas outras preocupações, que são as dificuldades apresentadas pelas crianças em processo de adaptação/readaptação no país de chegada. A família, quando migra para outro país, encontra-se desestabilizada, desorientada, em estado de confusão emocional, necessitando de ajuda alheia, portanto vivendo um estado de desamparo emocional.

O despreparo dos pais em relação aos filhos fica nítido quando a criança ingressa na escola. O sofrimento emocional passa a ser de ambos: os pais desorientados pressionam os filhos para que aprendam num ritmo acelerado, sem terem tempo de processar emocionalmente a nova vida; além disso, exigem que as crianças apresentem bons 
resultados em seus estudos; a própria criança, por sua vez, acaba se sentindo na obrigação de sobressair nos estudos. Ambos, pais e filhos, se sentem castrados pela nova e difícil realidade.

O sentimento de culpa dos pais está ligado à decisão de retornar ao Brasil, tanto por não terem consultado suas filhas como também pelo rígido tratamento educacional que têm dado a essas crianças. Os pais, ao perceberem que se trata de uma mudança radical e que vêm acarretando sofrimentos emocionais na família, se culpam por não terem anulado seus próprios objetivos no Brasil pelas filhas. Além de os pais sentirem culpa por tantas experiências dolorosas, as crianças manifestam a sua culpa por não conseguirem corresponder às expectativas desses pais em relação à difícil realidade. A culpa surge por não atingirem as médias nas avaliações escolares e, com isso, os filhos temem perder esse amor. Entretanto, essas crianças vivem, em suas fantasias, experiências de abandono que acarretam em desamparo emocional. Esses pais e as crianças imigrantes parecem padecer de um sofrimento de "culpa dobrada".

A escola é uma caixa de ressonância magnética, onde aparecem as dificuldades das crianças. Na sexta série, Eiko recebeu uma advertência na disciplina de língua portuguesa, porque fez uma menção de "não" com a cabeça quando a professora the pediu que lesse os verbos. Na disciplina de matemática recebeu a segunda advertência, porque se esqueceu de fazer a tarefa de casa. A forma de calcular a divisão no Japão é diferente da forma brasileira, e Eiko enfatiza que sofreu muito para aprender matemática e que chorava bastante porque a sua mãe não conseguia compreendê-la. Em suas lembranças, traz pensamentos de que não havia aprendido a matemática dessa forma: "Não sei fazer essa coisa". A "coisa" é a matemática. Diante de tantas dificuldades, surge o sentimento de desprezo para com a área de exatas. Afirma: "Aprendi divisão chorando".

O sofrimento de Eiko vai além da escola; em casa com a sua mãe, a senhora Natsu, tentava justificar as suas dificuldades no aprendizado de matemática. Nesse momento Eiko se via sozinha e incompreendida pela própria mãe, vivendo uma situação de desamparo emocional. 
Pesquisadora: Parece-me, Eiko, que a sua mãe não pode entender que era diferente a forma de divisão do Japão e do Brasil. EIKO: Não! Eu vi na apostila do Japão e mostrei para a minha mãe. Ela entendeu. Foi no ano passado. No quinto ano ficava pensando e a aula acabava. Não vi essa conta. Como posso fazer? O que significa? É menos? É mais? Não perguntava. Pensei: Acho que é uma forma do Brasil. Acho que não é de menos e não mais. PESQUISADORA: Parece-me que se sentiu sozinha. Como se não tivesse ninguém para lhe ajudar. EIKO: Sim! Teve um formulário e tive que escrever, eu não entendia o que era "emprego", só "trabalho". O sétimo ano era muito difícil.

Nesse questionário citado por Eiko, havia uma pergunta referente ao tipo de raça. Eiko ficou imaginando as cores: amarela, branca e negra. Optou por branca. Ela ri e fala que não sabia. Portanto, sente que mentiu em sua resposta escrita, por não ter conhecimento. Hoje, sabe que sua raça é amarela. Ela cita um exemplo dos degraus de uma escada, classificando-a gradativamente: ela se encontra nos primeiros degraus do ensino escolar, e os colegas, nos degraus acima; a prova, por sua vez, está classificada no décimo degrau. Eiko se sente atrasada em relação aos colegas de classe e isso tem consequências no aprendizado e na esfera emocional.

\section{Desamparo em relação à língua}

O aprendizado da língua portuguesa, para Eiko, vem sendo um dos principais problemas na chegada ao Brasil. As crianças que estudaram somente em escolas japonesas acabaram desenvolvendo a comunicação e a escrita no idioma japonês. No Japão, muitas dessas crianças passaram a se comunicar com os pais na língua japonesa, não fazendo uso da língua portuguesa em família. Além do mais, essas crianças que foram alfabetizadas na língua japonesa alcançaram um nível maior de compreensão do pensamento abstrato japonês, em cujo nível os pais não conseguem acompanhá-las, porque lhes falta conhecimento do idioma japonês e do pensamento simbólico da língua. Portanto, os pais estão em déficit na compreensão e na 
comunicação da língua japonesa com os próprios filhos, como se não pudessem ter mais livre acesso ao mundo deles. Quando essas crianças chegam ao Brasil, se deparam com a dificuldade da língua, além das diferenças culturais encontradas no país. Essas crianças, filhos de dekasseguis, passam a se sentir "estrangeiros" dentro do próprio país e, às vezes, dentro do próprio ambiente familiar, caindo em um estado de desamparo psíquico.

A menina Eiko tem um jeito japonês de comunicação oral. Fala com muita dificuldade a língua portuguesa. As conjugações verbais da língua portuguesa feitas por ela, muitas vezes, ficam "fora do tempo real".

Quando questionada sobre a sua dificuldade de adaptação no retorno ao Brasil, Eiko não hesita em nos dizer que a língua portuguesa tem sido uma "questão" em sua vida. Sente-se sozinha e atrasada em relação ao desenvolvimento do seu aprendizado escolar.

Hum... Com a palavra em português está um pouquinho difícil. E também não conseguindo ir junto com os meus colegas, eu atrasei um pouquinho.

As dificuldades do novo idioma são tantas que aparecem logo na própria entrevista; Eiko não consegue compreender a pergunta formulada pela pesquisadora no trecho a seguir:

PESQUisadora: Você poderia me descrever detalhadamente as dificuldades que está sentindo e a que você atribui essas dificuldades? EIKO: O que é "atribui"? PESQUiSAdora: O que acha que é no sentido, por que você está tendo essas dificuldades? Seria isso. EIKO: Porque, hum, ham... Os colegas fala em português e tem algo nas palavras que não sei. Eu me sinto com pouco de dificuldades. PESQUISADORA: Por que dessas dificuldades da língua portuguesa? Por que você acha que está com essas dificuldades? EIKO: Porque tem muitas palavras que eu ainda não aprendi e não consigo entender. [...] PESQUISADORA: Como você lida com essas dificuldades? O que faz para conseguir melhorar? EIKO: O que é "lida"? PESQUISADORA: Lidar é como você faz para conseguir 
melhorar. EIKO: Pergunto para o meu pai e mãe, a irmãzinha que sabe mais português [...]. Olho um pouquinho no dicionário, pergunto para professora e colegas. Não consigo aprender muito. PESQUISADORA: Por que você acha que não consegue aprender muito? EIKO: Hum. Porque é me acostumei no Japão e eu nunca usei o português no Japão. E acostumei falar japonês e não estou conseguindo aprender muito o português e é difícil.

Lembremos que no Japão a língua falada pelos pais e filhas era a língua japonesa. O processo se inverte ao chegarem ao Brasil: os pais passam a usar a língua portuguesa na comunicação com as filhas, cientes de que a língua não era do conhecimento delas. Repentinamente, a língua dos pais muda ao migrar para o Brasil: no Japão, pais e filhas falavam a mesma língua, a japonesa; e, ao chegarem ao Brasil, os pais passam a falar a língua estrangeira, ou seja, a língua diferente e que não era familiar. Além de Eiko estar vivendo o processo e a elaboração de luto por se separar do Japão, também tem de lidar com a perda da própria língua em família. As crianças se sentem "estrangeiras" dentro do próprio lar.

Eu com minha irmãzinha falava japonês. Às vezes, ensinava falar português, mas não conseguia aprender escrever, mas minha mãe e meu pai conversava em português e eu não entendia.

Podemos pensar em três situações de perda da língua nesse momento: a mudança de país; o fim da comunicação na língua japonesa em família; e o novo ambiente.

O desamparo emocional desencadeado pela perda de toda uma representação simbólica e cultural traz à tona o trauma do nascimento. Eiko se vê sozinha e desamparada, sem poder contar com a ajuda dos próprios pais.

As dificuldades da comunicação oral da língua portuguesa atravessam e acompanham outros territórios familiares. Elas são sentidas de ambas as partes, pelos parentes (tios e primos) e pela criança (e)imigrante, no caso, Eiko. 
[...] A tia entende um pouquinho o japonês. O tio não entende. Só o português. Com o primo só brincava e não falava. Com a prima foi acostumando com o japonês e foi entendendo algumas palavras.

\section{Paisagem do sonho}

Para tentarmos entender o mundo em que Eiko vive, perguntamos para ela em qual língua sonhava e qual era a paisagem dos seus sonhos. Ela tenta fugir da resposta, porém esclarecemos na pergunta.

Pesquisadora: A paisagem do seu sonho é do Brasil ou do Japão? EIKO: Às vezes aparece do Japão, dos amigos e dos professores. Às vezes do Brasil. Não sonho muito com o Brasil. Às vezes sonho com paisagem que eu criei também.

Na sequência:

PESQUiSADORA: Você sonha com mais paisagens do Japão ou do Brasil? EIKO: Com mais paisagens do Japão, porque lembro muito tempo, fica na cabeça. No Brasil, consigo ver a paisagem e eu esqueço, dá para ver de novo. No Japão não dá para ver de novo, acabo sonhando com do Japão.

A criança experiencia o sentimento de "fim", mesmo que esse "fim" seja por um tempo indeterminado. Menciona que não dá para encontrar o Japão novamente e, por isso, as suas paisagens são japonesas.

\section{Língua do sonho}

A língua falada no sonho de Eiko:

Todo japonês [ri]. Quando sonho no Brasil é japonês, não sei o porquê. Nunca sonhei português, nem inglês e língua diferente. PESQUISADORA: O que pensa de sonhar na língua japonesa? EIKO: Não sei o 
porquê, eu já acostumei a falar em japonês. No Japão nunca sonhei em português. As pessoas que estão no sonho falam inglês, português e japonês; e eu só falava japonês e eles me entendem. PESQUISADORA: Quem falava inglês? EIKO: A professora de inglês do Brasil. Eu não entendia o inglês, mas respondia algumas palavras que eu entendia. Eu respondia o que eu sabia. A professora de inglês respondia em inglês e eu falava com ela em japonês e ela entendia o japonês.

O mundo interno da adolescente Eiko, mesmo vivendo no Brasil, é completamente oriental. A paisagem e a língua sonhadas são japonesas. Eiko, em seu sonho, sente-se compreendida na língua dominante, a japonesa, embora não seja o que acontece na realidade. Sente-se sem voz e mal interpretada na língua portuguesa e desamparada emocionalmente.

Eiko não consegue fazer a interpretação da língua portuguesa para a japonesa para sanar as curiosidades das crianças brasileiras. Para isso, ela teria que possuir um vocabulário maior e a compreensão do pensamento abstrato. A comunicação entre Eiko e os demais colegas de classe não ocorre, paralisando-a diante do outro.

No Japão tem coisas gostosas. Roupas que vestia. Eu não conseguia trocar as palavras do Japão para o Brasil. Tem coisas que não tem no Brasil e é difícil de explicar. Exemplo: games do DS. ${ }^{3}$

\section{Tempo de recordações/língua}

Nesse dia, as duas irmãs trazem seus álbuns escolares e de alguns lugares ou parques que visitaram no Japão. As duas irmãs usam os dois idiomas, o português e o japonês, para se comunicar uma com a outra. A irmã Letícia intervém na língua japonesa, na tentativa de ajudar a irmã na compreensão da língua portuguesa. A irmã caçula dá a Eiko o amparo emocional na língua.

3 DS: Console de videogame da japonesa Nintendo cujos jogos não se encontram com facilidade no Brasil. 
No Japão, é costume ser chamado pelo sobrenome da pessoa. Eiko e Letícia não eram chamadas pelo sobrenome japonês, mas sim pelos seus nomes, o que é comum no Brasil. As crianças mostram fotos da escola e da sua turma de classe. Trazem também fotos em que estão com seus trajes típicos japoneses. Elas chegam para as entrevistas trazendo imagens do seu mundo, usando-o para voltar atrás no tempo, na tentativa de elaborar a separação e a perda.

Ao nos encontrarmos pela primeira vez, em 2013, entregamos-lhe uma legítima revista japonesa. A história em quadrinhos de Naruto é relatada por Eiko, na qual o personagem se libertou de um monstro interno e se tornou o salvador da pátria. Sua leitura é feita em voz alta e sem titubear.

Pesquisadora: Você teve dificuldade com a leitura japonesa? EIKO: Não tive dificuldade de ler. PESQUISADORA: É mais fácil ler o japonês do que o português? EIKO: É muito mais fácil, porque já estou acostumada e sei bastante o japonês.

A adolescente diz ter vontade de fazer amizades, porém, nos intervalos da escola, tem estudado a língua japonesa.

Pesquisadora: Por que tem que estudar japonês? EIKO: Para não esquecer e não perder para a minha amiga.

Em sequência, Eiko mostra o desejo de voltar para o Japão e ser professora de língua japonesa.

Quero ir e trabalhar. Ser professora de japonês. Não sei se vou conseguir. Porque se ficar adulta e tímida, não vou conseguir dar aula de japonês.

O esquecimento da língua japonesa traria muitas perdas para Eiko. A língua japonesa, além de representar a mãe japonesa, também é uma forma de estimular uma integração com as crianças 
descendentes de japonês e que estudam a língua. Portanto, manter a língua viva é manter o desejo vivo de retorno para o Japão.

Ao perguntar para Eiko o que traria do Japão para o Brasil: "Não traria 'judiação', porque lá os japoneses judiam com as palavras. Ao contrário, levaria do Brasil para o Japão as histórias de vida, as coisas que não tem no Japão e a música brasileira". Apesar dessa afirmação, ela só conhece o estilo de música sertaneja, que não faz o seu estilo nem o dos japoneses.

Já as revistas em quadrinhos de histórias japonesas traduzidas para português, Eiko não consegue compreendê-las totalmente:

Pesquisadora: Como foi ler o mangá português? Eiko: Consegui entender algumas partes e outras não. Se fosse em japonês entenderia tudo. PESQuisadora: Qual é a parte difícil do português? EIKO: Onde tem que entender o significado. Tem significado igual e muda as palavras. Não consigo entender. O japonês entendo bem melhor.

De acordo com Eiko, as imagens dos mangás brasileiros e japoneses são iguais, porém menciona que as palavras e a língua são diferentes: "Eu entendo mais o japonês".

Como aluna da escola japonesa, tirava notas vermelhas na escrita em kanji e fez aulas de recuperação até conseguir a média de 6 pontos.

O kanji era um pouco difícil de aprender, porque veio da China. Confundia com vários outros kanjis. $O$ adulto tem que aprender o kanji e dá para entender mais coisas e palavras. PESQUISADORA: Como se sentia no Japão? EIKO: Não tinha medo. Tinha que fazer a recuperação até tirar nota azul. Eu conseguia. Eu fiz duas vezes, estava difícil.

Apesar de Eiko dominar a língua japonesa, as dificuldades escolares aparecem com o aprendizado da língua na condição de imigrante no Japão.

No Brasil, sente-se como o seu cachorro que ouve o português, mas não entende. As dificuldades no Brasil são maiores do que no Japão. A falta de conhecimento da cultura brasileira, dos hábitos e dos 
costumes é árduo para Eiko. Por falta de conhecimento da língua portuguesa, não conseguiu entender as diferenças entre os termos masculino e feminino. Ainda se sente confusa e perdida nessa nova vida.

PESQUisadora: Você se sentiu igual ao [cachorro] Shiro, ouve o português, mas não sabe. EIKO: Sinto muito! É ruim! Eu não entendi o que estava escrito. Eu sou fiel. O que é fiel? É muito ruim! Se não entender, não dá sentido, nada. Se não entender a fala, só fica vendo desenho. Pesquisadora: Parece-me que não pode compreender o sentido completo. Sentindo que compreende as coisas pela metade. EIKO: Uhum. PESQUISAdORA: No Japão, aconteceu isso? EIKO: Quando estava no Japão entendia, mas não conseguia responder. Estava no infantil. Tinha 3 ou 4 anos. PESQUISADORA: Como fazia? EIKO: Respondia com a cabeça, mãos [gestos]. PESQUISADORA: Qual foi mais difícil, o Japão ou o Brasil? EIKO: Quando voltou para o Brasil foi mais difícil. Eu não entendi nada. Os amigos e amigas pediam para trocar para o japonês [os amigos pediam para falar o japonês, traduzir o português para o japonês]. Era difícil fazer, mas fazia. Não gostava, porque tinha que pensar. Só sabia algumas palavras em português. Não sabia as regras, os costumes. Ainda está sendo muito difícil. É mais fácil acostumar com os costumes, um ano. Estava muito tempo no Japão. Não pode tirar os sapatos. Não pode dar descarga no vaso com papel higiênico. Não sabia o banheiro masculino e feminino. Eu entrei no banheiro de homem. Se tem figuras, tudo bem! Foi numa loja. Pensei: "Banheiro de menino". Sabia o que era mulher, menina e menino e homem. Não sabia masculino e feminino. A porta do banheiro é diferente. No Japão, quando está ocupado fica vermelho, e azul quando está sem ninguém. Já fui devagar na porta e tinha uma pessoa, me assustei. PESQUISADORA: Você fala que estranhou muito o Brasil. Você ainda estranha? EIKO: Às vezes, um pouquinho. Quando anda de carro fica barulhento. Fazer coisas que não vi no Japão.

A língua japonesa é de extrema importância para Eiko se vincular ao Brasil. Define a língua japonesa como uma ponte que faz a ligação com a língua portuguesa. Porém, surgem a preocupação e o medo de 
esquecer a sua língua oriental, e, assim, a necessidade de estudá-la para que não caia no esquecimento. Esse medo de perder a própria língua, a língua dominante, nos remete a pensar que Eiko teme perder as suas referências orientais. Parece-nos que é uma maneira de conseguir se integrar, não esquecendo a mãe japonesa, mas se unindo com a mãe brasileira.

PESQUISADORA: O que pretende fazer nas férias? EIKO: Nas férias, estudar um pouquinho de japonês, que está esquecendo, e brincar um pouquinho. PESQUISADORA: Parece-me que você tem medo de esquecer a língua japonesa. EIKO: Para mim o japonês é uma ponte que atravessa a língua portuguesa. Não quero quebrar. PESQUISADORA: Como que é essa ponte? EIKO: Para mim, não consigo falar inglês e nem entender, não dá certo. Falta a língua portuguesa e a japonesa. Para aprender a língua portuguesa, tem que usar a língua japonesa. Exemplo: Uma palavra que não sabia, pergunto para a minha mãe e ela traduz. A minha mãe explica em japonês para entender mais fácil o português. PESQUISADORA: Você sente que precisa do japonês para entender a língua portuguesa. EIKO: É. PESQUISADORA: Quando não sabe a palavra na língua japonesa nem na portuguesa? EIKO: Se é palavra em japonês, se não entender, fico procurando no dicionário japonês. Em português não consigo. O dicionário explica difícil. Pra mim, não entende. PESQUISADORA: Então, vocêfica sem entender. EIKO: É.

A busca por respostas imediatas para a compreensão de mundo e o fato de nem sempre ser aquilo que condiz com a realidade deixam Eiko confusa e com muitas dúvidas.

Diante dos novos acontecimentos, reafirmo que esses filhos de dekasseguis passam a se sentir "estrangeiros" dentro do país que é considerado de origem, o Brasil.

O contato com a nova língua, no Brasil, é a grande problemática da comunicação entre pais e seu país, nesse novo mundo que até então era desconhecido e tão distante, porém tão próximo. 


\section{Desamparo no ambiente escolar}

A idade da criança imigrante deve ser considerada nesse processo de deslocamento. Lembremos que Eiko havia terminado o terceiro ano na escola japonesa e iniciado o quarto ano no Japão. Ela chega com quase 10 anos de idade no Brasil e ingressa na $4^{a}$ série da escola brasileira, alfabetizada na escrita japonesa, portanto, sem conhecimento algum do mundo escolar brasileiro. A língua portuguesa é totalmente desconhecida por ela.

Apesar da pouca idade como (e)imigrante, Eiko está vivendo outra fase imigratória em sua vida. Atualmente, está com 13 anos de idade, em transição da infância para a vida adulta; encontra-se na adolescência, entrando para a vida madura. Entre dois mundos, a infância e a puberdade, dentro dessas turbulências da própria fase de adolescência, surgem turbilhões de emoções sem se saber qual o caminho a ser enfrentado nessa longa jornada de transição.

No clube japonês de Marília, a adolescente se sentiu como se estivesse no Japão, amparada emocionalmente pela professora e as demais crianças. Justifica que a língua falada nessa instituição é a japonesa, que se usa pouco a língua portuguesa. A adolescente se sente na sua casa japonesa, onde fala a mesma língua, ou seja, a língua que conhece eque lhe é familiar.

É legal, não usa muito o português e elas também "conversa” comigo, não fico vergonha e não fico quietinha. PESQUISADORA: Isso no Nikkei Clube? No Nikkei você conversa? EIKO: Uhum. PESQUISADORA: $\mathrm{Na}$ escola que estuda você tem amigos? EIKO: Tenho pouquinho. Não consigo ficar muito amiga comum que eu fico no Nikkei. PESQUISADORA: No Nikkei já é diferente. Você sente que consegue ter mais amizades no Nikkei. EIKO: Uhum!

O sentimento de desamparo de Eiko fica claro dentro da sala de aula. No trecho seguinte, Eiko diz: "Eu perguntei pequeno", ou seja, ela não teve voz suficiente para falar e ser correspondida, e, por isso, não pode ser vista. Entretanto, faltou o olhar do adulto para que não caísse em desamparo emocional. 
PESQUiSAdORA: Disse-lhe que se o coleguinha fosse morar no Japão e fosse para a escola japonesa, também não saberia as palavras japonesas. É através das perguntas, ou seja, perguntando que vamos conhecendo. Você viveu alguma situação que não sabia e perguntou ao professor e os colegas riram? EIKO: Eu perguntei pequeno. PESQUISADORA: Vocêfalou baixo? EIKO: Não ouviu.

A preocupação com o futuro escolar é manifestado na quarta entrevista de Eiko: ir bem na escola é uma maneira de garantir um futuro promissor no Brasil.

Pesquisadora: Como que foi na prova? EIKO: Mal. Porque a matéria que está estudando são coisas de células, onde foi criada, nomes, memorizar é muito difícil. PESQUISADORA: O que é ir mal na prova? EIKO: Achei que vai tirar nota vermelha na prova. Tem que aprender mais. Se não conseguir recuperar a nota, acho que terei que fazer recuperação. Fico preocupada com o futuro. PESQUISADORA: Como assim, preocupada com o futuro? EIKO: Ficar de recuperação. Acho que não vou conseguir recuperar a nota. Fico com medo.

A leitura e a não compreensão da língua portuguesa fazem Eiko se desinteressar pelo texto: "Tem muitas palavras que não entendo. Não gosto. Gosto mais de aventura. Não é desse tipo de livro que gosto".

Podemos perceber que Eiko se sente socialmente desajustada e que gostaria de criar a sua própria história de vida, em outro lugar que escolhesse para morar. De certa forma, idealiza um novo lugar para a sua vida. Surge a fantasia de fuga para outro lugar muito melhor que o real.

Pesquisadora: Que tipo de livro você gosta? EIKo: Tipo de livro. Viagem ao centro da terra. Faz aventuras. Vai em outro lugar, que gosto. PESQUISADORA: Qual seria para você esse outro lugar que gosta? EIKO: O que os homens não "foi". O centro da terra. O sol. Coisas que ninguém conseguiu fazer [ri]. Fico imaginando dentro, assim. PESQUISADORA: Como que é dentro? EIKO: O centro da terra eu imagino que é 
um lugar muito lindo, tem árvores com folhas muito lindas, cachoeiras que brilham. Nunca as pessoas imaginam que tem na realidade.

O choque cultural é intenso no primeiro contato com a escola brasileira. Eiko enfrenta uma nova situação, encontra-se em um novo ambiente escolar que é totalmente estranho para ela. Sentiu-se perdida e muito assustada porque não sabia se era uma escola ou uma biblioteca. Nesse dia, os pais acompanharam Eiko até a porta de entrada da sala de aula.

O que eles estão falando? Será que eles não entendem japonês? Estava pensando. E aqui nesse balão a amiga estava falando coisa que não entendia. [...] PESQUISADORA: Quais eram as palavras que sabia? EIKO: Algumas palavras eu entendo. Não sei falar e nem escrever. Não sei perguntar. O que estava falando? Eu respondia: japonesa. Quando perguntavam as palavras japonesas eu respondia. PESQUISADORA: Quais eram as palavras? EIKO: Como se fala xícara em japonês? Se no Japão come sushi? Se na escola põem sapatos? PESQUISADORA: E lá no Japão põe sapato? EIKO: Só sapatos dentro da escola. Chama uwa-baki, ${ }^{4}$ não é sandália nem sapato, parece um chinelinho fechado. Pesquisadora: Como você se sentiu nesse dia? EIKo: Nossa! Um pouquinho! É realmente brasileiro? Estão no Japão? Muito assustada! Eles conseguem falar muitas palavras em brasileiro. Lugar é diferente. A professora parece brava. Senti totalmente diferente. PESQUISADORA: Como diferente? EIKO: Que no Japão e no Brasil é diferente. A escola é muito diferente. Estranhava. Não era escola. Pensava que não era escola. Porque usava caneta, usava dentro da escola sapatos, era muito grande a escola. Os professores, amigos e outras pessoas não "era" japonês. O rosto do japonês percebe que é japonês. O rosto do brasileiro parece italiano. Não limpava a escola. A escola acaba antes do almoço aqui. Eu estava pensando se era escola de verdade. Pensava que era outro lugar. PESQUISADORA: Que lugar que pensava? EIKO: [Ri.] Biblioteca. Até parecia. Acho que é biblioteca. PESQUISADORA: Quando foi

4 Uwa-baki: sapatilha que se usa dentro das escolas japonesas. 
percebendo que era escola? EIKO: Eu estava usando uniforme e as amigas também. Tinha as aulas que estava assistindo. Tinha prova. Essas coisas. Eu fiquei um pouquinho: escola ou biblioteca? Passava o tempo e eu entendi que era escola. Que a escola normal do Brasil era assim.

A percepção das diferenças culturais torna-se mais acentuada no ambiente escolar. Agora, a língua é outra, denominada por ela como a "língua brasileira". Comenta que os traços físicos dos brasileiros são distintos dos japoneses, percebendo a mudança de imagens entre os povos de culturas distintas. Eiko começa, então, a se deparar com novos costumes e hábitos na escola. Muitas dúvidas permaneceram, parecia não ter certeza de nada diante do choque cultural e do estranhamento diante do ambiente escolar.

No primeiro dia fiquei perdida. Quando terminou o lanche, "foi" no banheiro. Eu entrei no banheiro. As amigas foram beber água. Eu estava no banheiro, no primeiro andar. Eu saí do banheiro e não sabia onde estava o bebedouro. Não sabia onde estavam as amigas, mas procurei. Eu estudava no segundo andar. Eu procurei no terceiro andar e também no primeiro. Eu não sabia. Eu abria a porta e via o professor e os alunos. Nossa! Tinha esse amigo nessa sala? Até passei na minha sala. Não conseguia achar a minha sala. PESQUISADORA: E como achou? EIKO: Eu estava perdida. Uma moça perguntou o que estava acontecendo. Eu respondi: "Perdi”. Ela perguntou: "O que perdeu?". Eu respondi: "Eu". A professora estava procurando eu.

O sentimento de não poder encontrar a si mesmo, de ficar realmente perdida no ambiente escolar, ocorreu de fato. A busca pelo "eu" de Eiko não termina depois que ela é encontrada pela inspetora de alunos; torna-se uma busca incessante de se encontrar na vida. $\mathrm{O}$ relato anterior mostra que Eiko viveu mais uma experiência de desamparo emocional entre tantas outras.

A adolescente Eiko define, a seguir, o seu sentimento de estranhamento no país: 
Aqui é diferente. Assim, ficar um pouquinho com dúvida. Um lugar que nunca vi e nunca fui. PESQUISADORA: Onde você se sente estranha? EIKO: Mesa é diferente, mesa, piso parece uma pedra, o clima, o aré diferente, é quente. Tem pessoas falando línguas diferentes. Tem outras pessoas com rosto que não é Japão. PESQUISADORa: Você gosta de vir aqui conversar comigo? EIKO: Sim. Porque a professora [psicóloga] entende o que eu falo.

Vimos que surge o sentimento de não pertencimento, como se Eiko não identificasse ou não reconhecesse o seu "eu" na figura do "outro".

As principais queixas da adolescente se centralizam na escola. Percebemos que a escola também não está ajustada para lidar com as crianças migrantes e, assim, acaba fortalecendo os sintomas de inibição e repressão dessas crianças no ambiente escolar. De certa forma, a escola não deixa de ser uma instituição castradora.

Hoje, a dificuldade está na palavra. Tenho prova de português e inglês e não sei algumas palavras. A professora fala que não pode responder e eu não posso perguntar. Fico com dúvidas. Será que eu consigo? [...] PESQUISADORA: Você sabe hoje a sua nota de português? EIKO: Hoje não sei. Esqueci. A nota vermelha ficou de língua portuguesa e ciência. Ciência não estava muito ruim. Estou estudando bactérias e eu troco com vírus. PESQUISADORA: É a língua que não compreende e fica difícil de compreender o texto? EIKO [Meneia a cabeça, afirmando]: Cai outras palavras, fungos, bactérias, celulares. Eu confundo. Qual era qual? Quando tem a explicação da professora e pergunto: Fungo era o quêe? Não consigo. Na apostila o que é fungo, o que é bactéria, eu errei. Troquei. Acho que a explicação era da bactéria e coloquei no fungo. Fiquei um pouquinho com dúvidas nisso. PesQuisadora: Você pergunta para a professora? EIKO: Às vezes a professora de história fala que pode perguntar algumas palavras. A professora de português não disse para perguntar as palavras. É difícil entender o português. PESQUISADORA: Qual seria a solução? EIKO: Não quero que os professores e professoras coloquem as palavras difíceis. As palavras, tem milhões. Eu 
procuro no dicionário e eu não entendo nada. No dicionário está escrito difícil. Procuro e acho mais uma palavra difícil. Fico fazendo isso. Se eu perguntar para a minha mãe, ela responde, mas tem limite. Se eu perguntar trinta palavras para minha mãe, tem limite, fica brava. Não consigo perguntar muito. Se perguntar para o meu pai também fica bravo. No computador, às vezes não sei trocar a palavra japonês para português. Eu ensino japonês para a minha prima e ela ensina português para mim. Ela digitou isso, não era o que eu queria falar"sussurrar" - e a flor não fala baixinho. "Sasayaatteru" [no sentido de estar alegre e reunida]. Na internet saiu "sussurrando", não é esse o significado. No computador às vezes está errado. PESQUISADORA: Você gostaria de compreender melhor o português? EIKO: Não quero que coloca palavra difícil. Minha cabeça confunde. Vou procurando no dicionário e eu esqueço, por procurar muitas palavras. No computador se eu digitar no Google "aspectos" e sair em japonês, falo que entendi. Aí se a tradução estiver errada, acabo aprendendo errado. Por isso não consigo aprender muitas palavras.

Na escola, nem mãe brasileira nem mãe japonesa. É assim que se sente Eiko, órfã e sem as duas mães para ampará-la.

Diante da vivência de Eiko, indagamos se ela teve dificuldades que ficaram marcadas em ambas as escolas, a japonesa e a brasileira. Ela responde que não, porém não estará perto para ver os amigos crescerem e sente medo de não poder reconhecer mais a fisionomia do que lhe era familiar; há o sentimento de estranhar o que era conhecido e de ter que lidar com a separação e perda. Surge o temor de perder suas próprias referências.

Na escola do Japão não fiquei chateada com os amigos e amigas. Fiquei chateada quando fui voltar para o Brasil. Fiquei chateada, se crescer quer me ver. Eu também quero ver. Estou pensando, se conseguir voltar lá no Japão, não vou conseguir ver os amigos. Vão mudar os rostos, altura e o modo com que as pessoas... Na escola do Japão não era quietinha, tinha medo que todos rissem de mim. PESQUISADORA: Eles riam de você? EIKO: Quando fazia alguma coisa engraçada. Quando 
caía no chão, nunca riram de mim. PESQUISADORA: O que você falava de engraçado? EIKO: Contava histórias engraçadas de livros de desenhos do Japão. Pesquisadora: Parece-me que todos riam junto com você e não riam de você. EIKO: É. Eu quero ir à faculdade do Japão, não dá para ir agora. Os amigos do Japão, lá tem pessoas que morrem. Não sei se consigo ver. PESQUISADORA: Você fala com esses amigos? EIKO: Minha escola não usava internet, porque era a partir do quarto ano. Não tinha e-mail.

Podemos perceber nessas crianças a ausência de vínculos com as pessoas que ficaram no Japão. Atualmente, vivemos num mundo globalizado, em que a rapidez das informações e das comunicações se propaga na velocidade do tempo e espaço. Portanto, o transnacionalismo parece estar ausente no mundo dessas crianças.

\section{Escola japonesa}

PESQUiSAdora: No Japão, qual a disciplina que era a mais difícil? EIKO: Acho que era o Kokugo, ${ }^{5}$ que é a língua do país. Tinha Kanji. Eu tinha mais dificuldade em Kanji. Pesquisadora: Por que tinha dificuldades em Kanjis? EIKO: Eu achava difícil. Tinha que decorar para a prova. Na vida inteira tinha que deixar lembrado. A forma de escrever é diferente. Tem iguais e isso é muito difícil.

Eiko nos contou que na escola japonesa havia uma classe internacional, onde crianças de outros países aprendiam o idioma japonês. O aprendizado do idioma japonês é dado concomitantemente com o período de aula. A criança é retirada da sala de aula e, por um período, passa a frequentar a sala internacional. Eiko era uma das crianças que frequentava as aulas de reforço para aprender a língua japonesa. Ela também disse que não sabia nada em relação ao ano em que se encontrava na escola. Não sabia se estava adiantada ou atrasada. Tudo era muito confuso.

5 Kokugo: [s] língua japonesa; língua pátria (Ohno, 1989, p.383). 
Eu estava na quarta série e tinha que fazer várias aulinhas. Fotos, revistas. Eu escolhi ajudar as pessoas. Pegar lixo. Não conseguia ir, porque não conseguia levantar. Dormia. Só fui uma vez. PESQUISADORA: Você, Eiko, era uma boa aluna? EIKO: Da primeira até segunda série, sim. Da terceira até a quarta fiquei ruinzinha. Porque na primeira e segunda série tinha medo dos meninos e não conseguia falar as coisas. Porque o menino batia na menina.

No Japão, Eiko aprendeu a se defender das crianças japonesas e, com isso, também protegia uma menina que era maltratada pelos meninos. Encontrou um jeito de mostrar o seu punho fechado, no sentido de inibir a ação desses meninos. Na escola japonesa recebeu o apelido de "demônio" e, depois que se viu no espelho, aceitou o apelido, pois viu e sentiu que era um demônio. Esse outro lado representa o lado forte de Eiko, a defesa para a vida. Na escola japonesa, o comportamento de Eiko é bem diferente do comportamento na escola brasileira. No Japão ela sabia se defender, mas no Brasil usa de defesas primitivas, como se afastar das pessoas, ou seja, usa do isolamento e da esquiva para não se vincular ao outro.

\section{Escola brasileira}

Na escola, fiquei chateada no começo com todo mundo, fiquei um pouquinho. O rosto, a língua, a altura era diferente, fiquei com medo. PESQUisadora: Qual era esse medo? EIKO: As pessoas do Japão não falam as palavras, ficam magoadas. No Brasil já ouvi tanto as palavras burra e chata. PESQUISADORA: Falaram para você? EIKO: Não. As amigas falam para outras amigas. Fico com medo de ser falada. No Japão falava isso quando a briga era muito terrivel. Exemplo: jogava a cadeira e falava burro, chata e idiota. No Brasil falam brincando essas palavras, não percebem que o outro fica magoado.

Eiko costuma pensar e se preocupar com o seu futuro. Teme não conseguir concretizar o seu desejo de retornar para o Japão. Por ser criança, a preocupação ainda permanece pequena e distante da 
realidade; com o passar dos anos, a preocupação se tornará maior e próxima da nova realidade. Portanto, é neste período que irá se encontrar com o seu próprio tempo, ou seja, o "tempo das suas escolhas", e talvez decidir qual será a sua nova direção.

PESQUisadora: Como está a preocupação, pequena ou grande? EIKO: Está pequena, porque sou criança. Os meus pais são novos. Então, não vou trabalhar ainda. No futuro a dúvida vai ficar maior. Se eu conseguir tirar nota boa na prova de japonês, vou entrar na faculdade com 18 ou 19 anos.

A língua portuguesa ainda continua sendo difícil para Eiko, como vemos no relato a seguir:

A matéria eu consigo entender mais ou menos. Não consigo entender o que está pedindo na pergunta. Vou procurar no dicionário e não consigo entender. Vou procurando e aí já esqueci a primeira palavra que estava procurando.

Após três anos morando no Brasil e estudando numa escola brasileira, pergunto-lhe se sente dificuldades.

Um pouquinho. Ainda não consigo entender o exercício. Às vezes, a professora fala e eu não consigo entender. E a minha língua que falo, o português é muito difícil de entender. PESQUISADORA: É difícil que o outro lhe entenda? EIKO: Acho que sim. A professora de matemática pediu para cortar o papel e eu cortei kirigami, ${ }^{6}$ e o papel dobrado, origami. Eu escrevi um livro, tinha que apresentar o que fez. Na minha vez não tive coragem de mostrar para a professora, para entender para os outros. A professora leu, todo mundo da classe ficou com rosto de dúvida. E disse que era difícil de entender. A irmãzinha disse também. Eu pareço tudo com japonês e a irmã com brasileiro. PESQUISADORA:

6 Kirigami: prática artística, como o origami, que utiliza como matéria-prima o papel cortado. 
A professora pediu que você explicasse? EIKO: Não. Mas conseguiu entender. É difícil de entender um pouquinho.

O aprendizado da língua portuguesa e a sua compreensão abstrata continuam sendo as principais queixas de Eiko. Além disso, Eiko acaba percebendo que as outras crianças não conseguem compreendê-la quando lê sua redação, demonstrando dúvidas que ficam estampadas no rosto delas

$\mathrm{Na}$ escola, na hora do intervalo, Eiko às vezes procura a companhia da irmã menor ou da prima de 16 anos de idade. Não procura vincular-se a outras crianças. Explica que não gosta do sol do Brasil por ser muito quente. A adolescente parece caminhar pelas sombras, se escondendo do brilho do sol.

Às vezes, elas têm coisas para fazer e eu não quero ir. Às vezes tenho que estudar. Às vezes não quero sair lá fora, não gosto do sol, que é muito forte para mim. No Japão é fraquinho, aqui parece um deserto e acabo ficando com minha irmã e a prima. Eu fico me escondendo do sol. Fico resmungando um pouquinho.

\section{Intervalos na escola}

A vivência de ser abandonada é sentida por Eiko dentro da própria escola. Sente-se sozinha e desamparada emocionalmente, reforçando na adolescente um sentimento de desistência em vincular-se ao outro. $\mathrm{O}$ processo de adaptação à vida escolar de Eiko tem sido longo e demorado, desencadeando sofrimentos emocionais em sua vida.

Teve uma vez que pedi para amiga lanchar junto comigo e elas me deixaram. Fui ao banheiro e me esqueci de perguntar onde elas iam comer. Eu não consegui encontrá-las. Procurei por alguns minutos. O horário estava passando e lanchei sozinha. Voltei para sala de aula e pedi desculpas para as amigas. Elas também me pediram desculpas, porque não me disseram onde iriam comer. PESQUISADORA: Hoje, você lanchou com quem? EIKO: Hoje fiquei sozinha. Às vezes eu fico sozinha para ir 
à biblioteca e ficar desenhando. PESQUISADORA: Você conseguiu lanchar alguma vez com essas amigas? EIKO: Sim. Eu gostei, mas quando estava lanchando os meninos vieram e não tinha lugar para sentar, tive que mudar de lugar. Perto do banheiro onde tinha um cantinho. PESQUisadora: Você ficou sozinha nesse cantinho? EIKO: Não. As amigas também mudaram. PESQUISADORA: Parece-me que não gostou de mudar de lugar? EIKO: Não. Tinha sombra e ventava mais no lugar.

As dificuldades de se vincular ao outro ficam nítidas na escola. É como se Eiko estivesse num estado de congelamento, como se tivesse parado no tempo passado e não conseguisse sair mais desse estado. Emocionalmente, Eiko deseja até arriscar e sair dessa situação, porém o corpo permanece uma estátua de forma enrijecida. Ela não está conseguindo viver por inteiro: encontra-se dividida entre dois mundos, Brasil e Japão. Analisando psicanaliticamente, o lado estátua, o que fica congelado, é o seu lado morto, que evita sentir, que nega a nova realidade. O outro lado, mais enfraquecido, é o que representa a vida, e está completamente anulado na vida de Eiko. Os colegas de classe até tentam se aproximar da amiga que voltou do Japão, mas não conseguem alcançá-la. No trecho seguinte, fica claro que Eiko se sente sozinha e desamparada emocionalmente. Será que Eiko vai conseguir se adaptar ao Brasil? Embora os colegas de classe tentem inseri-la no contexto social, Eiko não se identifica com a turma.

É um pouquinho difícil. A minha aparência na escola é silenciosa e gelada com todo mundo. Pesquisadora: O que é aparencia silenciosa? EIKO: Não fala muito. Muito baixinho. PESQUISADORA: E aparência gelada? EІкО: Exemplo. As pessoas falam: Vamos brincar? Eu falo não. Não quer mesmo? Não. É gelado com as pessoas. Não quer brincar muito. PeSQuisadora: Você tem vontade de brincar quando te convidam? EIKO: Tenho! Não gosto de brincar. PESQUISADORA: Parece-me que já fica indisposta a não ir brincar. EIKO: Sim! Eu gosto de desenhar, do que movimentar o corpo e a cabeça. Fico desenhando. PESQUISADORA: Deve ser triste ficar sozinha. EIKO: É, mas quando estou desenhando 
a atenção está toda no desenho. Então, o professor entra na sala e não vejo. Dou atenção aos desenhos. Não consigo ficar ligada a outras coisas. PESQUisadora: Parece-me que fica distante daqui. Como se não estivesse no Brasil. Distante. EIKO: Está longe o que eu penso dos sentimentos dos outros. Meus sentimentos no Japão e os sentimentos dos colegas no Brasil. Quando eles vêm conversar diminui um metro. Eles ficam berrando para alcançar os meus sentimentos. PESQUISADORA: Parece-me que eles querem você perto deles. EIKO: Eu não fico ligando. Fico no cantinho da sala. PESQUISADORA: Deve ser difícil não se permitir fazer contato como outro. EIKO: Parece que sim! Na aula de reforço de português me chamou para ir à lousa. A vontade "querer ir", mas o corpo não quer ir, não quer mover. PESQUisadora: Ficou dividida. EIKO: Todo dia é assim. Penso: "Vou me esforçar". O corpo fica parado. Não consegue mover. PESQUISADORA: Você já tentou ajudar o corpo a se mover? EIKO: Já tentei! Fui ao meio do caminho e voltei. PESQUISADORA: Qual é o sentimento que aparece aí? EIKO: Quero mudar um pouquinho. Ainda está igual quando veio no Brasil, mas o corpo acostumou. Não quer acreditar de verdade. Já acostumou com pessoas do Japão, cultura e língua. O corpo sente mais do que sentimento, não quer fazer mexer. PESQUISADORA: Lá no Japão era diferente? EIKO: Era bem diferente no Japão. Estou brincando e conversando com os amigos. Estou sozinha no Brasil. Estou juntos com os amigos no Japão. Quando começava a aula todos prestavam atenção. No Brasil berram. Não prestam atenção, então é difícil um pouquinho. PESQUiSADORA: Quando você olha e vê que está no Brasil, como que é? EIKO: Já conversei com a mãe. O meu sentimento e corpo não quer acertar isso. Estou sentindo que estou no Brasil. O sentimento de verdade, não quer acertar. Está muito difícil.

Na escola, apresenta uma "fisionomia séria", ou seja, uma "fisionomia fechada", como se ficasse o tempo todo na defensiva para não criar vínculos com o outro. Portanto, diz que é porque não está nem muito feliz nem triste. Mostra preocupações com as avaliações de geografia, porque não conseguiu memorizar as informações. Apresenta dificuldades em conjugar os tempos verbais e não consegue escrever corretamente a língua inglesa. 
EIKO: Fico muito feliz! Acho que até chorar. Fico feliz! PESQUISADORA: O que você imagina? EIKO: Vou voltar aonde nasci e cresci. Acho que consigo encontrar com amigos e amigas. Brincar de novo nos lugares. Falar o japonês. Fico muito feliz! PESQUISADORA: Você fica sentindo que está lá no Japão? EIKO: É!

Ela reprovou a quarta série do ensino fundamental na escola brasileira, mas isso não parecia ser importante para Eiko, pois ela desconhecia o significado da palavra "reprovar". Ela disse que não manifestou nenhum sentimento e que no momento não considerava importante essa situação.

Eu estou aprendendo e esquecendo coisas que aprendi no $6^{\circ}$ e $7^{\circ}$ ano. Estou esquecendo. PESQUISAdORA: Por quê? EIKO: Se eu aprender coisas novas, esqueço que aprendi no passado. [Eiko retira o seu jogo eletrônico da sacola e nos ensina a brincar.]

Para Eiko, o aprendizado no Brasil é sentido como uma ameaça para as suas referências, de forma que aprender a nova cultura poderá representar o "esquecimento" e a "perda" do velho mundo japonês. É como se não aprender fosse a maneira que encontrou de manter o Japão vivo dentro de si.

Filhos de dekasseguis: brasileiros ou japoneses?

A identidade é um assunto complexo e muito discutido pelos pesquisadores. Especialmente quando se trata da identidade dessas crianças imigrantes, já que Eiko nasceu no Japão, embora não seja japonesa nata. A adolescente estudou em escolas japonesas e conviveu com a cultura desse país.

No trecho a seguir, ao ser questionada sobre a sua identidade, apresenta dúvidas como se não pudesse pertencer a nenhum país; portanto, ela não tem uma resposta pronta. 
Hum, acho que nenhum dos dois, no Japão também as minhas amigas e meus amigos ficavam falando que eu era brasileiro e no Brasil falava que eu era japonesa, e não conseguiu do qual sou brasileiro ou japonês.

Essas filhas de dekasseguis são crianças que têm a experiência de viver em duas culturas, são consideradas híbridas. Surge em Eiko o sentimento de ambivalência, de ficar no Brasil, mas também de construir o futuro próximo no Japão.

EIKO: Que é "intenção"? PESQUISADORA: Vontade. Qual a sua vontade? EIKO: Quero ir no Japão fazer outras coisas, fazer minha faculdade, mas também quero ficar no Brasil e fazer o [Nome do comércio dos pais], meu pai e mãe vai [Nome do comércio dos pais], porque fica velho no [Nome do comércio dos pais], então também quero ficar no Brasil e no Japão.

Logo no primeiro dia de escola, Eiko é apresentada à classe, pela sua nova professora, como sendo japonesa. Os alunos questionavam Eiko sobre a sua identidade, perguntando-lhe se era chinesa ou japonesa. Ela mesma responde dizendo que é japonesa.

A professora falou: "Nova aluna é japonesa, vai estudar aqui". Todo mundo fez: "Oooo...". Todo mundo veio, começou a conversar. PESQUisadora: O que eles conversavam? EIKO: Se é japonesa ou chinesa. Pesquisadora: O que disse? EIKo: Era japonesa. Era difícil de usar um pouquinho o brasileiro.

A identidade surge na questão da consanguinidade, diante do sentimento de impotência de Eiko que se evidencia nas dificuldades escolares. Destaca que o seu sangue também é "brasileiro".

Gosto. Às vezes fico chateada e triste. Porque colega consegue e eu não. Eu também sangue de brasileiro. Porque eles conseguem fazer essas coisas e fico chateada e triste. PESQUISADORA: O que você gostaria de conseguir? EIKO: Conversar mais. Eu não quero ser tímida. Quero mais 
amigos e amigas. PESQUISADORA: Você acha que a timidez lhe atrapatha em alguma coisa? EIKO: Sim. Quando pede para ler, não consigo. Os colegas vão rir de mim. Fico tímida e acabo não lendo.

Em outro momento, a adolescente justifica as suas diferenças culturais, a sua identidade, ao afirmar que é totalmente japonesa e a que sua irmã é brasileira.

Quando era pequena no Japão era igual, até 3 anos. Depois que subi um pouquinho ficou diferente. Ela, a Letícia, estudou coisas de deuses. O Japão não acredita em Jesus, mas os brasileiros acreditam. Eu fiquei parecida com o japonês. Quando escrevo a letra e a irmã, fica muito diferente. A letra fica muito redonda. PESQUISADORA: Cada pessoa tem a sua forma de escrever. EIKO: Hum? "Forma"? PESQUISADORA: O jeito de escrever. EIKO: Mas eu gosto da minha letra. Porque as professoras falam que a minha letra é bonita.

Ao ver uma foto da cidade de Bastos, de quando esteve no Brasil pela primeira vez, enfatiza que conseguiu se sentir brasileira pela condição de lugar. Entretanto, não se lembrou por inteiro, como se faltasse uma parte de si mesma.

Fiquei um pouquinho feliz vendo a foto. Vendo a foto eu consegui sentir que era brasileira também. PESQUISADORA: Como é a foto? EIKO: Por exemplo: eu morava em Bastos. Tinha museu, ossos de dinossauros. Lembrava quando via a foto. Só parte da foto que lembrava do Brasil. Outros não consegue lembrar.

O Japão e o Brasil já tinham enfrentado uma partida de futebol em terras brasileiras. O jogo foi no domingo, dia 23 de junho de 2013, na Copa das Confederações. Eiko não assistiu à partida, alegando que não tinha sinal de TV em sua casa e que ficou brincando com seus jogos e lendo revistas japonesas. Questionamos Eiko: para qual time ela torceria? Ela nos responde: "Se torcer, quer torcer no Japão". 
Pesquisadora: Por que torce para o Japão? EIKO: Porque é meu país. Pesquisadora: O Brasil ganhou de 3 a 0 contra o Japão. EiKo: Eu acho o Brasil forte. PESQUISADORA: Quem você acha que vai ganhar, Brasil ou Japão? EIKO: Acho que Japão. Eu acho $30 \%$ de vencer. O Japão também ficou forte. Se perdeu do Brasil, acho um pouquinho fraco.

Afirma que o Japão é o seu país e que se fortaleceu, porém, se o Japão perder a partida contra o Brasil, é porque está enfraquecido. O lado japonês de Eiko é o lado dominante, mesmo que não sobressaia como vencedor.

\section{Filhos de dekasseguis: o difícil retorno}

A adolescente Eiko tem curiosidade de conhecer o lugar onde passou parte da sua primeira infância, mesmo que exista uma mistura de sentimentos de tristeza. Agora era sua segunda viagem ao Brasil, sem previsão de retorno ao Japão. Eiko havia estado pela primeira vez aos seis meses de vida e morado por quase dois anos e meio no Brasil, antes de ir ao Japão.

Essa segunda viagem não é simplesmente uma mudança para o Brasil. É uma despedida do mundo oriental, mesmo que seja por um tempo indeterminado.

Fiquei um pouquinho triste, mas eu também queria vir no Brasil, porque queria conhecer. Estava pensando quando era pequena, ouvi onde que eu fiquei, quando era fica no Brasil [sussurrou as últimas palavras].[...] Não queria sair da escola, porque tinha amigas e amigos, professoras e professores que eu gostava e tinha minhas primas, tias e tios e avós.

A criança, ao imigrar para outro país, sente falta do ambiente social que fazia parte da sua convivência. A separação do país, da escola e dos amigos é sentida pela criança como duras perdas com as quais terá de lidar quando migra de um lugar para outro. O sentimento de tristeza é a representação simbólica do luto. 
Eiko relata que foi consultada sobre o retorno ao Brasil, mas que a decisão foi dos pais, conforme o relato a seguir:

Fui, mas tinha que vir, não tinha jeito. Eu também queria conhecer o Brasil. Porque o Brasil, na minha memória, não consigo lembrar nada. Só vendo a foto que consigo entender que estava aqui.

A primeira vez que Eiko ouviu a mãe dizer que iria voltar para o Brasil, estava na primeira série. Ela foi informada de que, quando chegasse na sexta série do ensino fundamental, iria retornar para o Brasil. Argumenta que faltava um mês para a viagem de partida quando soube da decisão tomada pelo pai de ir embora para o Brasil. $\mathrm{Na}$ época, estava no início da quarta série no Japão e, até então, não sabia de nada. A princípio Eiko se sentiu feliz, queria ver o Brasil novamente. Porém, lamentou deixar os amigos.

Pensei que fosse morar no Brasil e depois voltar para o Japão. [Eiko percebe que não poderá voltar ao Japão após um ano morando no Brasil, que não pensou sobre o que os pais vieram fazer no Brasil.] PESQUisadora: Por que pensou que fosse retornar para o Japão? EIKo: Eu acho o Japão minha casa. [...] PESQUISADORA: Como considera o Brasil? EIKO: Um país diferente. [A adolescente diz que pensou que as cidades brasileiras fossem mais bonitas que as cidades japonesas. Viu ruas sujas e feias. Porém, gosta da natureza do Brasil, do arco-íris que só viu uma vez no Japão, neblina, cachoeiras, etc...]

Essa mudança tão radical de retornar para o Brasil não deve ter ficado bem esclarecida para Eiko. Para ela, o Brasil é o país de destino e o Japão, o país de origem. Eiko continua idealizando o Japão como um país bom e desvalorizando o Brasil, interessando-se apenas pelo mundo selvagem da natureza brasileira.

Quando Eiko chegou ao Brasil, logo no primeiro dia, teve dificuldades para dormir (é importante lembrar que o fuso horário entre o Japão e o Brasil é de doze horas). Ela se depara com o sentimento 
de estranhamento do tempo e do espaço. Além disso, os hábitos e costumes brasileiros são distintos da cultura japonesa.

Depois "foi" em casa e dormi. Dormi rapidinho. Estava com sono. Era outro lugar. A gente dorme a primeira vez. Não consegui dormir até chegar amanhã. Eu e a irmã estávamos brincando no corredor, de desenhar. No avião dão presentes só para crianças, e estávamos vendo outras coisas. PESQUISADORA: Por que não conseguiu dormir? EIKO: $O$ ar é diferente. O lugar que no Japão dormia era deixar o colchão no chão e dorme. Nunca dorme na cama. Fiquei um pouquinho estranha e não consegui dormir. PESQUISADORA: O que mais sentiu diferente no Brasil? EIKO: Muito grande. Em casa entrava com sapatos. Tinha o banheiro, não podia dar descarga com papel higiênico, no Japão podia.

Na sétima entrevista, Eiko traz duas músicas japonesas: uma sobre o tempo e os sonhos para o futuro, e outra sobre os desejos que gostaria de realizar. Outro mecanismo de defesa que aparece no relato seguinte é a cisão, pois o Brasil e o Japão não podem ser misturados, ou seja, não podem ser integrados.

Eu não queria misturar assim. Eu gosto de separar. Se eu copiei no Japão, é no Japão. Não posso misturar com do Brasil. Igual o origami ${ }^{7}$ [pássaro de papel] que vem tudo misturado e tem que separar. Não quero misturar. Igual à comida do Japão é toda separado. PESQUISADORA: Por que não poderia estar juntado? EIKO: Porque se juntar, não sei. Alguma coisa dentro de mim fala: "Separa, separa essa coisa". Então separo.

A fantasia que Eiko trazia sobre o Brasil era de uma época muito primitiva. É a mesma noção que os japoneses têm do Brasil. Para eles, o Brasil se resume às cidades de São Paulo, Rio de Janeiro e a Amazonas. Subentende que o Brasil todo se compõe de apenas três estados.

7 Origami: dobradura (f) (Hinata, 1998, p.338). 
Nessa viagem para o Brasil, Eiko voltaria ao estado mental primitivo e faria um novo nascimento.

Índios, desertos, índios pelados e que comem bichos. Os japoneses ficavam falando e tinham uma foto também. Eu pensei que fosse assim. Vi uma foto de Cristo. Nossa! Homem branco que está grande! Está morando lá. Pensei que tivesse o dourado e o rosa em outras cidades. Acho que tem no Amazonas, é um lugar muito conhecido em outros países. Foi melhor quando chegou. [...] As pessoas que voltam para o Brasil, a gente gosta do Japão. O Brasil era muito quente, falava língua diferente. Eu ficava resmungando essas coisas. Se passar muitos anos no Brasil acaba gostando um pouquinho.

\section{O contato com a pesquisadora}

Eu achei muito bom. Porque eu não conversava com os brasileiros. Melhorei um pouquinho. O que eu não consigo conversar, converso com a Cizina. Eu acho legal também aqui. Porque eu não conversava com os brasileiros, tinha um pouquinho de vergonha de errar a palavra. Tinha vergonha de falar a palavra: o que eu faço? Como eu explico essa palavra? Eu pensava tudo na cabeça em japonês e trocava em português. Quando não consigo trocar uma palavra, não consigo responder. Exemplo: a palavra japonesa hottikisu significa prendedor de folha. Eu não conseguia trocar essa palavra. Não respondi a pergunta que a amiga deu. [...] PESQUISADORA: Você gostou de mudar do Japão para o Brasil? EIKO: Ainda um pouco de saudades do Japão também. No Brasil também tem coisas legais, mas acho bom ter mudado para o Brasil também. Pesquisadora: Quais as saudades que sente do Japão? EIKO: Ainda o meu tio está lá. O pai do meu primo. Estou preocupada um pouquinho. No Japão acho que vai vir um tsunami ${ }^{9}$ de novo. Eu quero ver os amigos e as amigas. Esse tsunami é muito grande e faz tempo que não vem. Se vir, o Japão pode sumir. Tenho medo, um pouquinho. Meu

8 Hottikisu: grampeador (apropriação de hotkeys).

9 Tsunami: maremoto. 
avô disse que o Japão está gastando muito dinheiro. As pessoas estão viajando para onde quer. Não sabe quando vão vir. Antes de morrer querem comprar as coisas e viajar. Têm muitas pessoas assim.

Perguntamos a Eiko se, quando viu o seu álbum de fotos, recordou-se do Japão. O que sentiu? O que pensou?

Quero ir de novo ao Japão. Eu quero ir brincar. Tirar fotos. Quero comprar para o meu pai e mãe. Exemplo: Disney, comer... Ainda quero. Quero ver meus amigos. Brincar no parque de diversão. No futuro, ir à faculdade do Japão. PESQUISADORA: Parece-me que sonha muito com o Japão. EIKO: Sim. PESQUisadora: Como você se imagina lá? EIKO: Que o Japão está mais lindo, mais desenvolvido, mais alegre, feliz, assim.

Em sequência:

Pesquisadora: E aqui no Brasil, como está? EIKO: Está um pouco difícil de falar a verdade. O sentido verdade para as pessoas. Tenho um pouco, já me acostumei no Japão. No Brasil têm coisas, costumes diferentes. Não consigo me acostumar muito com os costumes e a cultura. Não consigo ficar muito alegre. PESQUISADORA: Por que está falando que está difícil dizer a verdade? EIKO: Minha personalidade tem bastante e igual eu. Fácil de falar e comunicar, mais do que no Brasil. No Brasil a personalidade é diferente das personalidades das pessoas. É difícil falar, não consigo muito. PESQUISADORA: Por que não consegue ficar muito alegre? EIKO: Algumas vezes trago notas vermelhas. A minha mãe não fica muito brava. Fico um pouco triste. Não consigo falar a verdade para amigas e amigos. PESQUISADORA: Do que você tem medo? EIKO: As minhas ideias são diferentes dos brasileiros. Eu tenho medo. Tenho medo de falar dessa ideia esquisita. Tenho medo de passar que os japoneses têm ideias esquisitos. Então, não falo. PESQUisadora: Você se sente muito sozinha? EIKO: Não sinto, mas às vezes sim. PESQUISADORA: Dê um exemplo dessa ideia esquisita? EIKO: Agora, tem um trabalho de "ensino religião". Não sabe de Japão e nem 
japonês. Eu queria falar várias coisas. PESQUISADORA: Quais são as coisas que gostaria de falar? EIKO: Se fazer assim, não fica bom. Se achar esquisito, fico um pouquinho triste e não fico falando. PESQUISADORA: Parece-me que tem receio de não ser compreendida. EIKO: É. PESQUiSADORA: Gostaria que as pessoas the compreendessem. EIKO: Fico um pouquinho triste. PESQUISADORA: Você consegue compreender todo mundo? EIKO: Às vezes. Quando eu não gosto, não. PESQUISADORA: Como seria no Japão? Você seria compreendida? EIKO: Acho que sim. A gente usa ideia dos outros. Usa de todo mundo. A gente vai indo e consegue fazer. PESQUISADORA: No Japão, você sente que todo mundo pode ajudar a todos. No Brasil você se sente sozinha. EIKO: É.

Nos cadernos trazidos por Eiko estão suas produções artísticas, os seus desenhos. Conta-nos que os fez aqui no Brasil. Alguns desses desenhos ela mesma criou e outros são tirados da internet, ou seja, observa os desenhos e copia os seus traçados. Ela é uma garota muito crítica quando os desenhos não ficam do jeito que deseja; diz que vai redesenhá-los. Percebemos a perfeição dos traços, a expressão marcante nos olhos dessas figuras que parecem mostrar os sentimentos de alegria, tristeza, preocupação e raiva. A clareza e a leveza dos seus traçados fazem reconhecer que Eiko já é uma grande artista. A maioria dos seus desenhos é de rostos de pessoas que parecem falar, ou seja, ter voz.

Por meio das projeções dos desenhos trazidos por Eiko pudemos perceber que ela trava uma grande luta em sua vida, a batalha para vencer na escola e na vida. Aparecem sentimentos de impotência e de tristeza ao não conseguir atingir a nota média na escola.

PESQUiSAdORA: Você sente que está lutando sozinha? EIKO: Não sinto muito. Um pouco. Pesquisadora: Como é esse pouco? EIKo: Contra as provas e os exercícios também. PESQUISADORA: Parece-me que essa luta é difícil. Você sente que está conseguindo? EIKO: Mais ou menos. Às vezes sou derrotada também. PESQUISADORA: O que é "derrotada"? EIKO: Quando tem prova e tirar nota vermelha. Sou derrotada. Pesquisadora: Como você fica? EIKO: Fico um pouquinho triste. 
Como fala...? Não é "consigo". Pesquisadora: "Tentar"? EIKO: Sim. PESQUisadora: Quando você tenta, consegue ou não? EIKo: Quando tento, percebo que não consigo. Não quero desistir. PESQUISADORA: Você já desistiu alguma vez? EIKO: Quando tenta, tenta e tenta. Não consigo e desisto. Se crescer mais um pouquinho, volta e faz. Às vezes no mesmo dia. Às vezes demora um ano. PESQUISADORA: Parece-me que precisa de um tempo para poder aprender.

Eiko sorri e afirma que necessita de um tempo para o desenvolvimento do seu aprendizado. Num outro desenho, a figura expressa o desejo de vencer. Ao questionarmos sobre o seu sentimento de querer vencer também, diz "sim" e que não deseja perder coisas como as provas e as amizades. Expressa o desejo de vencer nos estudos e na vida.

Muitas fantasias acabam surgindo no mundo interno de quem está partindo para outro lugar. O tempo da despedida é de extrema importância para a criança imigrante, pois permite a elaboração de um luto mais saudável, sem agravar o seu estado emocional. A despedida da escola e dos amigos de classe pôde ser feita por Eiko.

Pesquisadora: Quando saiu do Japão, você despediu dos seus amigos? EIKO: Os amigos não foram até o aeroporto. Na escola abriram uma festa de despedida. Eles mandaram mensagens, fez joguinhos e eu dei joguinhos. PESQUISADORA: O que falavam as mensagens? EIKO: Era legal ficar com você. Você era gentil também. É coisas boas e de verdade que estava falando. Mas também não sei se sou gentil e bonzinho. PESQUISADORA: Por quê? EIKO: Tem pessoas que só vê o lado bom e lado ruim. É difícil só acreditar do lado do bem. Muda muito fácil e pode ser mentira. É difícil de acreditar. Se o outro falar e ainda acredita. Se eu falo é difícil acreditar. PESQUISADORA: Por que não pode acreditar nas suas coisas boas? EIKO: Ainda quero acreditar. Se o lado bom faz o bem para outras pessoas. Não sei se esse lado é bom ou mau. PESQUISADORA: O que é bom? O que é lado ruim? EIKO: Ajudar as pessoas. O lado ruim é ficar falando mal dos outros. Judiar dos outros. Não obedecer a mãe e o pai. PESQUISADORA: Parece-me que fica em dúvida qual é o lado que 
você tem. EIKO: Uma pessoa tem o lado ruim e o bom também. PESQUISADORA: Você tem os dois lados. EIKO: Sim!

Em abril de 2013, Eiko resolveu ter o seu próprio perfil num site de redes socias. Ela conheceu um adolescente no Nikkei Clube, descendente de japonês. No Facebook, não é nada tímida, envia mensagens, exige resposta do outro e, quando não a obtém, ameaça-o com um soco, como fazia no Japão. Portanto, até nas redes sociais vive um desamparo emocional, faz tentativas para criar vínculos e não consegue, não é respondida, como se não fosse possível criar vínculos com outra pessoa.

EIKO: Você está bem? Responde alguma coisa! Se não responder, vou entrar no meio do seu Facebook e vou aprontar. Se eu encontrar com você, vou te dar um chute. Ele falou para a amiga. Ele disse que não quer encontrar Eiko. Se eu encontrar com Eiko, ela disse que vai me matar. PESQUisadora: Parece-me que você espera uma resposta dele. EIKo: Hum hum. Pesquisadora: Vocês vivem como gato e rato. Quem é o gato dessa história? EIKO: Ele é o rato. Ele é mais inteligente de português. Eu sou inteligente de japonês. O gato tenta pegar o rato, mas o rato está com o cachorro e não consegue. PESQUISADORA: Eiko, parece-me que pegou uma pessoa para conversar com você, que não fala. EIKO: Ele fez o pedido para o Facebook. Eu fico um pouquinho brava no computador. Parece que estou conversando sozinha. Parece que estou conversando eu mesma e por isso fica brava. PESQUISADORA: Qual a sensação de conversar com você mesma? EIKO: É um pouquinho esquisita. Parece que estou conversando com eu.

Em casa tem conversado com o cachorro de estimação. Para Eiko, o cachorro é como se fosse uma pessoa e ele entende mais o japonês do que o português, porque desde pequeno só ouviu o japonês e não sabe o português. Eiko projeta no cachorro os seus sentimentos de impotência e as dificuldades de adaptação à língua: "Eu fico conversando com o cachorro. Oi, Shiro! Você está bonitinho! Mas eu não entendo as palavras dos cachorros!". 
As comparações entre os dois países continuam sendo feitas pelas crianças imigrantes, mesmo com o passar do tempo. Eiko descobre que no teto da sua casa há várias teias de aranha que ficam no alto do corredor, e ela não gosta de aranhas e pequenos insetos. Ela diz que está se acostumando mais com a casa, apesar de ser diferente do Japão. Aparece no relato seguinte de Eiko uma das sensações mais primitivas do ser humano, que é a sensação "olfativa". O Brasil e o Japão cheiram diferente. "Pesquisadora: Vocês gostam da casa? Eiko: Agora, já estou mais acostumada. A casa é diferente. $\mathrm{O}$ cheiro do Japão é um pouquinho de chuva." Para Eiko, o Japão não cheira a "fedor": "Não cheira no Japão. Lá o lixo tem lugar para pôr. Às vezes voltava da escola estava cheirando um pouquinho, mas não era esgosto".

\section{Sentimentos de vergonha}

A adolescente Eiko, por ter se adaptado ao Japão, considera-o muito importante. Sente-se acolhida pelos colegas japoneses de classe e não se sente desamparada emocionalmente. No Brasil, porém, surgem vários sentimentos. A vergonha é um deles e está relacionada ao medo de errar, de se expor, reforçando o isolamento de Eiko. Existe o desejo de se comunicar com as demais crianças, mas ela se sente paralisada diante da nova realidade.

EIKO: O Japão é mais, acostumei mais Japão, e consigo ficar, não ficar com vergonha e, assim, não ficar sem conversar com colegas, conversa com colegas, então eu gosto de lá. PESQUISADORA: O que é o Brasil? O que você pensa do Brasil? EIKO: Legal e importante para mim. Mas a língua é diferente do Japão, eu fico um pouquinho com dúvidas e não consigo falar muito com colega e fico um pouquinho com judiada com comigo mesmo. PESQUISADORA: Como é ficar judiada com você mesma? EIKO: Porque não consigo, não consigo ficar, falar o que eu quero e de conversar. Tenho vergonha de falar errado e fico quietinha, não consigo. 
O sentimento de vergonha da criança filha de dekassegui também está relacionado com o medo de ser ridicularizada pelos colegas de classe.

EIKO: Não aprendo o português. Aprendi com a mãe, o pai e a irmãzinha. Tinha palavra que o som era alto e não conseguia falar $e$ ficava com vergonha. PESQUISADORA: Dê um exemplo? EIKO: A palavra "hifen". PESQUiSADORA: O que é vergonha? EIKO: Vergonha éfalar errado, outras conseguem. Exemplo: irmãzinha é mais nova que eu, não consigo e fico com vergonha.

O hífen faz parte da língua portuguesa, tem a função de separar e ao mesmo tempo manter ligadas as palavras, formando um único sentido. A não compreensão de Eiko da palavra "hífen" caracteriza o seu estado emocional, como se não pudesse fazer uma ligação entre as palavras, ou seja, entre os dois mundos. Eiko diz se esforçar, que vai tentar integrar-se ao meio, reforça que vai conversar com os amigos e professores, porém surge a preocupação de ser mais tímida do que a irmã Letícia: "Por exemplo: a Letícia fala de tudo: - A minha mãe construiu uma loja. Tenho vergonha. Sou tímida. O que eles pensam de mim?"

A leitura feita por Eiko na sala de aula mostra o quanto tem sofrido com o aprendizado. Cada passo dado por ela é uma conquista; mesmo lendo com a voz tímida, quase sem força, persiste nela o medo de cometer algum erro e ser motivo de chacota na classe. A sua rigidez é extrema, como não se permitisse falhar perante si mesma. O sentimento de vergonha percebido por Eiko em outras crianças foi algo que lhe causou surpresa. Foi importante para Eiko perceber que esse sentimento de vergonha não é sentido somente por ela, mas também por outras crianças.

EIKO: Tenho vergonha, ainda um pouco. Já li uma vez que a professora pediu. Pesquisadora: Como foi? EIKo: Todo mundo ficou um pouco contente. PESQUISADORA: O que sentiu na hora em que estava 
lendo? EIKO: Senti que não posso errar. Tenho medo de ser hidoi ${ }^{10}$ para todo mundo. PESQUiSAdORa: Eiko, o que é hidoi? EIKO: Eu não sei falar em português. PESQUISADORA: Fale do seu jeito. EIKO: Hidoi é todo mundo falando que ela errou. Tenho medo de ter sido "zoada". Uma vez na aula de artes, eu fiquei conversando com as amigas, disse que a voz era pequena. PESQUISADORA: Como assim? EIKO: A voz muito baixinha. PESQUISADORA: Elas ficaram zoando de você? EIKO: Elas falaram que também têm vergonha de ler o que está escrito nas apostilas. Eu também tenho que expressar mais um pouquinho. PESQUISADORA: Você percebeu que todos sentem vergonha. EIKO: Eu achei esquisito quando elas têm que falar e não falam. Elas conversam quando não precisam. PESQUISADORA: Você sente muita vergonha? EIKO: Alguma coisa não deixa falar. PESQUISADORA: Você tem vontade de falar? EIKO: Quero falar também, mas tenho medo.

As formas de cumprimentos são distintas em ambas as culturas. Na cultura japonesa o cumprimento é feito com uma menção com a cabeça e o corpo; no Brasil, com o abraço, beijo no rosto e apertos de mãos. Eiko diz que esse tipo de cumprimento brasileiro para os japoneses significa um vínculo amoroso. Por não compreender a cultura brasileira, se sente invadida pelo outro e acaba se defendendo de ser abraçada e beijada.

Eu bati no menino. Eu pensei que fosse de verdade. Eu tinha vergonha. Até em abraçar as meninas. Eu não estava acostumada, porque no Japão não tinha essas coisas. PESQUISADORA: Hoje como você os cumprimenta? EIKO: Com os meninos faço diferente, dou as mãos. Tenho vergonha. No Japão abaixo a cabeça, que é normal. As meninas ainda beijar não. Cumprimento no rosto, só encostando. PESQUISADORA: Parece-me que é difícil o cumprimento aqui. EIKO: Quando estava estudando no Nikkei, tínhamos a mesma idade. Tinha um menino da minha idade que havia chegado do Japão. Eu brincava de pular nas

10 Hidoi: [adj] forte, intenso, violento, extremo, cruel, terrível, atroz (Ohno, 1989, p.191). 
meninas. Ele ficou assustado, porque não estava acostumado. É que no Japão é muito diferente. Essas coisas de abraçar faz no ensino médio. Quando está namorando.

O sentimento de vergonha sempre surge quando as crianças se expõem diante de uma situação corriqueira e é sentido por elas como medo de errar - uma vivência constante na vida delas -, como se não pudessem lidar com as falhas e o fracasso, ou seja, com sua própria impotência. A vergonha e o medo de errar mostram o quanto a cultura japonesa está assimilada por essas crianças. A perfeição e a condenação parecem caminhar juntas nas tradições milenares do povo japonês.

\section{Urashima Taro}

Quando Eiko se encontra em outro país, percebe-se em um mundo à parte, distinto daquele que já conhece. Surge um estado de congelamento do tempo, do espaço e dos seus sentimentos. Às vezes, esses turbilhões de emoções e percepções se desmoronam diante da vida. Podemos fazer aqui uma analogia com o conto infantil japonês Urashima Taro, no qual um o pescador que se descongelou dos anos que viveu no fundo do mar, ao se deparar com a nova realidade, percebe que o tempo não poderia mais voltar atrás e o espaço havia mudado com o passar dos anos.

EIKO: Sim. Ele era um japonês que salvou a tartaruga dos rapazes que estavam maltratando-a. Veio a tartaruga maior e levou para o reino no mar e depois ele quis voltar para cima e lá embaixo tinha uma princesa que deu um caixinha para ele e ele abriu. PESQUISADORA: O que ocorreu? EIKO: O tempo do mar é bastante diferente do tempo da terra. Pesquisadora: Como assim? EIKO: O tempo do mar era devagar de passar e o tempo da terra era rápido. [...] PESQUISADORA: Parecem-me os dois mundos, o Japão e o Brasil. Como que é para você? EIKO: O tempo passa rápido quando estou muito alegre e quando não estou alegre o tempo passa devagar. [Silêncio.] PESQUISADORA: Está pensando? 
EIKO: Por exemplo: quando está na aula com prova, passa rápido. Porque não consigo perceber o tempo que está. Porque é uma coisa séria. Quando brinco com colegas, irmãzinha, o tempo passa rápido, quando percebe está na hora de dormir. PESQUISADORA: O tempo sempre passa rápido para você? EIKO: Quando tem coisa triste o tempo passa devagar. Quando vejo o relógio só passou 5 minutos. Quando está alegre, o tempo passa rápido. Quando está chateada, o tempo passa devagar. Eu não encontro resposta, por que o tempo algumas vezes passa rápido e outras vezes passa devagar. PESQUISADORA: Você ainda não sabe? EIKO: Parece que na prova, parece estar em outro mundo. Só tem eu e a prova, não consigo pensar em outras coisas. A prova não gosto. Não consigo perceber o tempo, está passando rápido.

O sofrimento emocional de Eiko está presente nesses dois mundos tão diferentes, e ela não consegue ter conhecimento do seu espaço e do seu tempo real. O sentimento de tristeza parece ter tempo e espaço maiores em sua vida no Brasil. O desamparo emocional de Eiko, nessa citação, encontra-se no tempo e no espaço em que vive, sem se entender e sem compreender o cenário do seu novo mundo, como ela mesma diz: "Eu não encontro resposta, porque o tempo algumas vezes passa rápido e outras vezes passa devagar”. 


\section{Análise dos desenhos}

\section{Chegada ao Brasil}

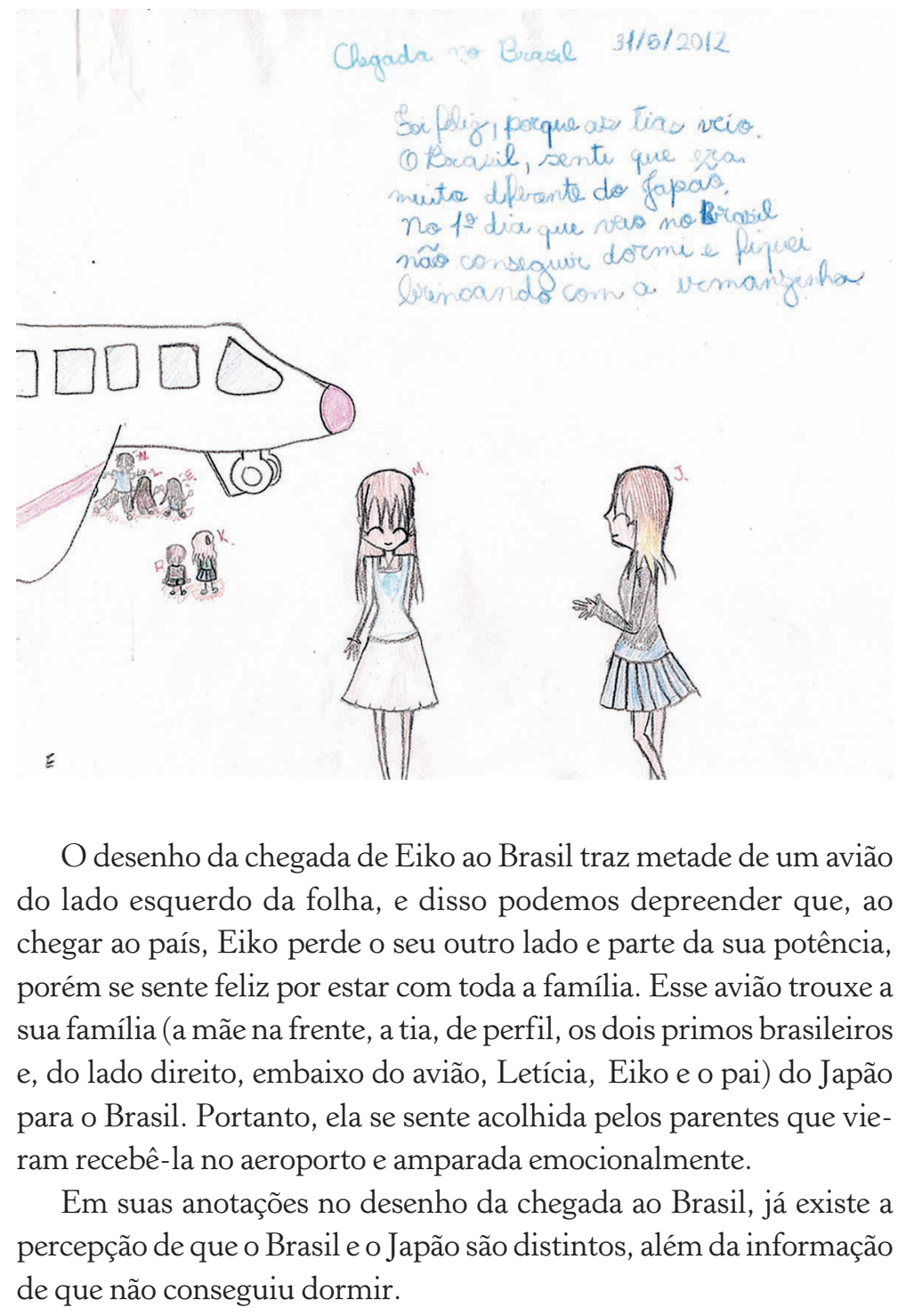




\section{Chegada ao Japão}

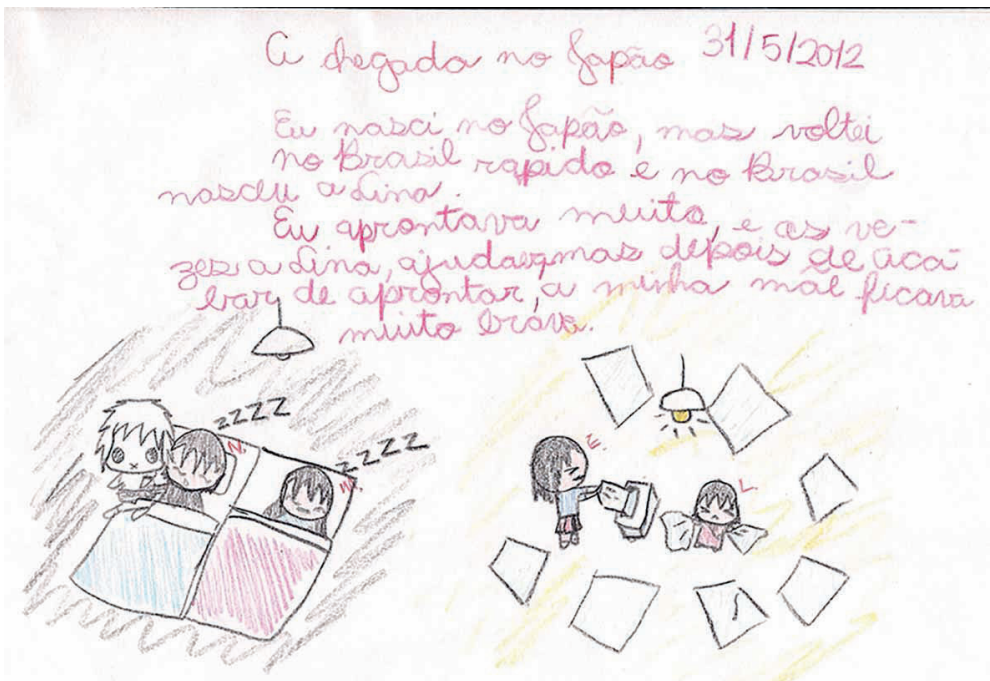

Afirma Eiko que nasceu no Japão, e por isso não teria ido para lá. Neste desenho, os pais estão dormindo em um quarto, enquanto Eiko e a irmã estão brincando com caixinhas de lenços em uma sala da casa japonesa. Mesmo tendo deixado a mãe brava ao esparramar os lenços pela sala, Eiko não se inibe e se sente em casa, se divertindo e sentindo-se à vontade, no estado que ela denomina "estar aprontando" ou fazendo algo de errado. 


\section{O primeiro dia na escola}

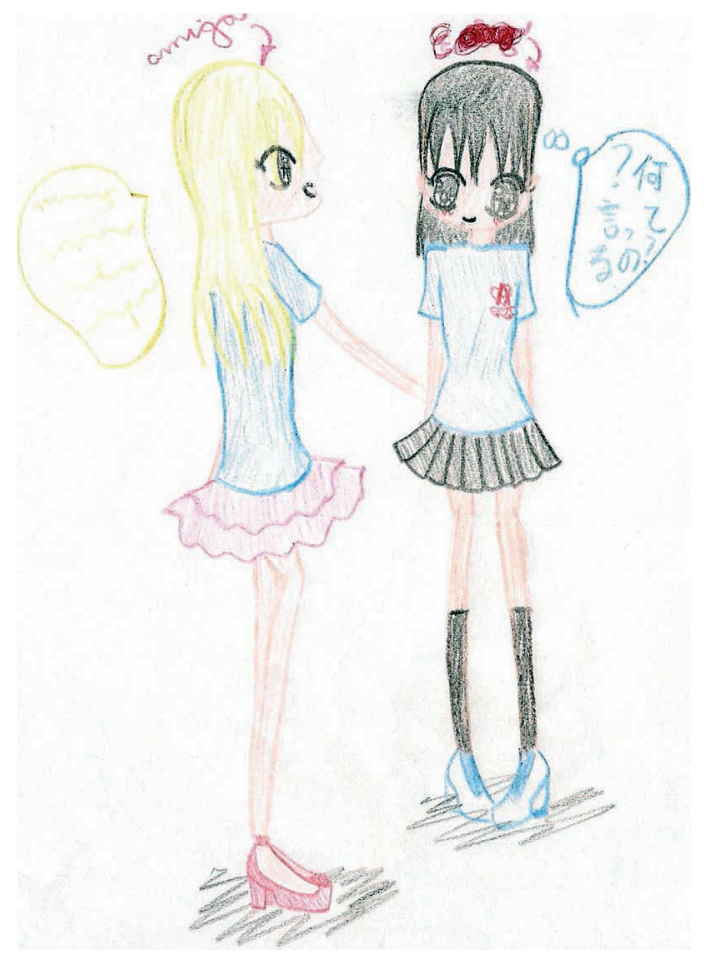

Este desenho mostra a expressão corporal de Eiko diante do desconhecido ambiente escolar. A figura feminina que representa Eiko está de frente: os olhos são amendoados, grandes e desproporcionais ao rosto; os pés estão voltados para dentro; os braços, postos para trás, como se estivessem nítidas em Eiko a sua timidez e a vergonha. $\mathrm{Na}$ figura, há ausência do nariz, como se perdesse seu faro e ficasse sem direção.

Os balões são os pensamentos de Eiko, que não entendia o que as outras crianças e a colega de classe desenhada ao seu lado lhe perguntavam. Sem saber a língua portuguesa e desconhecendo o local, a criança se sentiu assustada com essa nova realidade. $\mathrm{O}$ ambiente era de curiosidade por parte dos colegas de classe pela nova aluna que havia acabado de chegar do exterior. Entretanto, Eiko fica paralisada diante dos colegas e praticamente sem voz para repetir algumas 
palavras no idioma japonês que eles lhe questionam. Apesar do acolhimento físico, Eiko se sente perdida e sozinha, e vive uma situação de desamparo emocional.

\section{Desenho do rabisco}

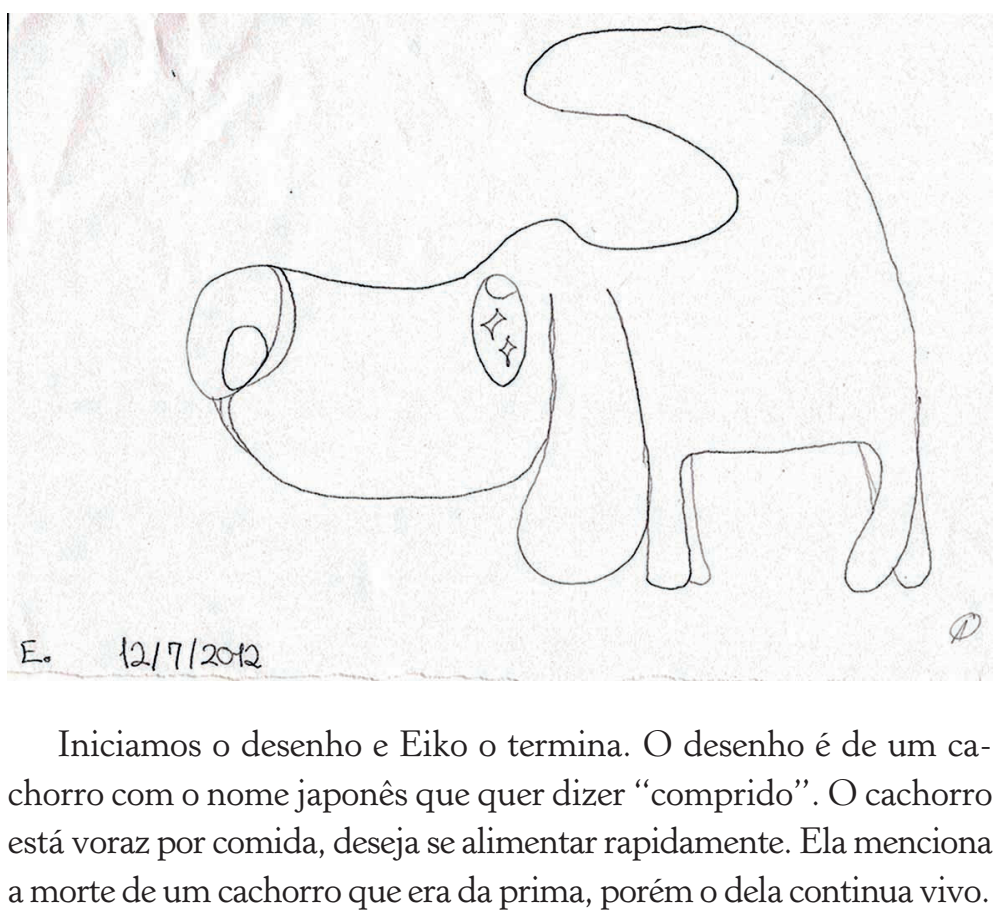




\section{Segundo desenho do rabisco}

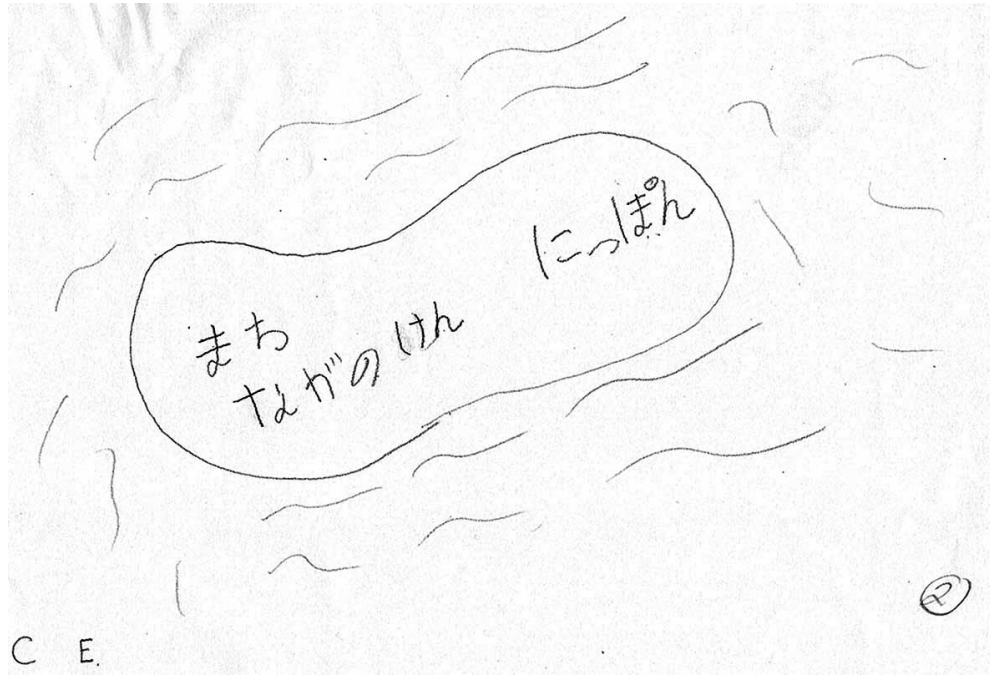

Neste segundo desenho da técnica do rabisco, Eiko inicia e nós o terminamos. Eiko diz que pensou que fôssemos fazer um barquinho com duas pessoas na região Norte do Brasil. Desenhamos o Japão e logo ela traz as lembranças dos amigos e professores que deixou lá. O sentimento de perda da própria liberdade em terras brasileiras, de passear e de brincar, sugere o medo de ladrão. Na sua fala aponta que em ambos os países, tanto o povo brasileiro como o japonês são diferentes. Além disso escreve em japonês, no corpo do desenho, as palavras: Cidade, Nagano-Ken e Japão, como se estivesse nomeando o lugar onde nasceu no Japão.

\section{Caso Letícia}

\section{Vivência de desamparo de Letícia com os pais}

A companhia da família no processo de migração é sentida pela criança Letícia como um amparo para as suas angústias. A criança recorre aos pais para livrá-la das dificuldades que estão em seu 
entorno. "Eu tinha dificuldade, mas com família é melhor ficar sem dificuldade. Fico perguntando pra a minha mãe e pra o meu pai."

A criança Letícia enfatiza sempre a importância de estar junto com a família no Brasil. A felicidade é considerada holding familiar e também poder continuar com a sua vida. "Felicidade, para mim, é uma felicidade de vir aqui no Brasil. Feliz, para mim, é ir junto com a minha família e ir à escola."

A senhora Natsu faz a função materna de interpretar e traduzir os novos significados da língua e da cultura brasileira à sua filha. Como é de conhecimento de ambas, a língua japonesa é usada para fazer a ligação entre os significados da linguagem e a compreensão para o mundo brasileiro das palavras.

PESQUiSADORA: Você canta em japonês ou em português? LeTíCIA: Japonês. É difícil cantar em português. Japonês é mais fácil. Tem aquela palavra "inclusive", eu achava que era menos. PESQUISADORA: Como descobriu? LetícIA: Eu perguntei para a minha mãe. Inclusive os usuário. Aí "inclusive" não é menos. A minha mãe explicou direitinho $e$ eu entendi. PESQUisadora: Você pediu explicação para os professores? LETícia: Eu não pedi explicação para os professores, eles falam em português e a minha mãe fala em japonês, e ela entende mais.

Letícia afirma que ainda há palavras da língua portuguesa que lhe são difíceis e outras que não o são. Ela tem se sentido desmotivada para consultar o dicionário, alegando que perde tempo e que a sua curiosidade é baixa.

O dicionário perde tempo. Eu pergunto para minha mãe, se ela não souber, deixo de lado. Não quero saber mais. A minha curiosidade é muito baixa. Que não tenho muitas dúvidas. Tem palavras que são fáceis para todo mundo, mas eu não sei. Quando eu procuro no dicionário, como eu canso! A professora mistura português com matemática! Que as coisas são diferentes. Guarda as coisas importantes na cabeça. 
Além de retornar para o Brasil, Letícia teve que deixar parte da sua família, com quem convivia, no Japão - os avôs maternos, tia e primos que não puderam retornar. Menciona a palavra "saudades" para se referir à falta da terra japonesa e dos seus familiares, a qual define como "alguma coisa que quer encontrar, mas não dá".

O tempo passado é um tempo de lembranças, saudades e mortes. A criança relata que desde os 5 anos de idade vem pensando nas futuras mortes que pode ter em sua vida. Essas mortes representam as várias perdas que tem enfrentado na vida de criança imigrante. Quantos lutos Letícia terá que elaborar emocionalmente?

\section{Desamparo em relação à língua}

O encontro com a língua portuguesa no Japão não soava "familiar", mas "estranha”, ou seja, a língua portuguesa era a língua "estrangeira” para Letícia. O fator idade ao chegar ao Japão ainda pequena e a condição de ser criança imigrante em terras orientais favoreceram para que aprendesse a língua japonesa na escola, embora ela não a considere fácil. Ao chegar ao Brasil com 7 anos de idade, a criança enfrenta problemas com a língua portuguesa e também com o fator idade, por já ser maiorzinha e sentir na própria pele a experiência de desamparo emocional do idioma.

PeSquisadora: O Japão e o Brasil ficam misturados? Letícia: Não! Não é que o Japão é tão fácil. Eu fui para o Japão e ficou fácil para mim. Estudei desde criança. Quando vim para o Brasil ficou difícil para mim, porque não acostumava, não sabia ler. PESQUISADORA: Você assistia aos filmes brasileiros no Japão? LetícIA: Não. Porque não sabia o português. Tinha uma loja de brasileiros, pequena e que vendia de tudo. Pensava: “O que eles estão falando?”. Pesquisadora: Você gostaria de saber o que eles estavam falando? LETícIA: Eu não queria saber! Porque pensava: "Se eles forem bobos?". Pensava que tivessem errando o japonês. Não pensava que tivesse o japonês e o português. 
No mundo de Letícia só existia a língua japonesa, era como se não houvesse espaço para as duas línguas, a japonesa e a portuguesa. A criança não compartilha em seus relatos nenhum contato com a língua portuguesa em casa, com os seus pais. Ao se deparar com a língua portuguesa, demonstra surpresa ao ver e ouvir todos conversando e se comunicando em outra língua, a qual não era conhecida pela criança. Portanto, Letícia percebe, no Japão, a existência e a dificuldade da nova língua.

$\mathrm{Na}$ chegada ao Brasil, o sentimento de estranhamento surge diante da nossa cultura. Além de os costumes e hábitos serem diferentes dos orientais, a língua portuguesa se destaca entre as queixas trazidas por essas crianças no contato com o país de chegada, que era para ser "familiar", porém soa "estranha". A criança Letícia é brasileira nata, mas, por ter imigrado para o Japão antes de completar um ano de vida, não traz lembranças de um Brasil conhecido. O Japão representa a maior parte da sua vida.

PESQUisadora: Você viu essa diferença e qual é a dificuldade? LETícIA: A dificuldade era saber português. PESQUISADORA: Você não sabia português? LETícIA: Não. PESQUiSADORA: O que você falava no Japão? Letícia: No Japão eu só falava japonês. PESQUiSAdora: Você falava só o japonês!

A língua falada em família era a língua japonesa. Portanto, a língua portuguesa soava "estranha” para a criança Letícia.

Pesquisadora: O que você fez para aprender o português? LETíCIA: Eu estudei mais ou menos com minha mãe e com irmã, fui aprendendo e quando quase há 4 anos. Eu tava mais ou menos, estava aprendendo. PESQUiSAdora: Quando chegou você disse que não sabia o português. Como você fez para conversar com o seu amigo? LETícia: Minha mãe comprou um livro de português. Eu não sabia ler, mas a minha mãe falou como era a letra, então eu consegui ler mais ou menos. Pesquisadora: E hoje? Letícia: Hoje está muito fácil para ler e pra escrever. PESQUISADORA: Você fala bemo 
português? LETícIA: Eu não sei, mas acho que falo mais português do que o japonês.

A solução para "o não saber" da língua portuguesa de Letícia é ter a sua mãe por perto, para receber o amparo emocional necessário de que precisa. Portanto, Letícia, sozinha, tenta procurar por respostas a fim de compreender essa nova linguagem cultural de mundo. Dessa forma, é uma tentativa de crescer e buscar certa independência.

Nessas dificuldades tem um monte de palavras que não pergunto para a minha mãe e por isso eu tenho que procurar no dicionário, e tem palavra de novo que não entendo, por isso procuro de novo no dicionário, aí então entendo o que é.

A criança Letícia, apesar das muitas dificuldades com a língua portuguesa, num primeiro momento, aos poucos foi interagindo com a turma de sua classe e conseguiu construir novos vínculos de amigos. Portanto, ela se sente amparada pelos seus pais e amigos.

Pesquisadora: Você tem amigos? Letícia: A classe inteira sabe o meu nome e eu gosto de ficar conversando com eles. PESQUISADORA: Você acha que seus amigos te compreendem? LETícIA: Sinto, quando meus amigos colaboram e meus pais também, eu aprendo o português, mas acho que é um pouquinho difícil e por isso tenho que estudar. PESQUISADORA: O que acha difícil no português? LETÍCIA: As palavras "R" e "L" ficam muito difíceis de falar. PESQUISADORA: Quer falar mais alguma coisa? LETÍCIA: Eu vim no Brasil, eu sou feliz, aprender brasileiro e encontrar com novas pessoas.

Ressaltamos que as crianças descendentes de japoneses têm dificuldades em pronunciar e escrever algumas letras do alfabeto da língua portuguesa, porque no alfabeto japonês não constam algumas letras que fazem parte do nosso vocabulário, por exemplo a letra "L”, que é pronunciada como "R". São tantas diferenças que 
vão surgindo na chegada ao novo país e, mesmo assim, a criança demonstra o desejo de aprender a língua portuguesa, a qual é chamada por ela de "brasileiro".

\section{Língua do sonho}

O sonho de Letícia parece ser mudo, não tem "som”, porque não tem uma língua. O som do mundo representa, simbolicamente, uma língua, ou seja, uma comunicação abstrata e não simplesmente uma comunicação mecânica instrumental. A ausência do som no sonho é a representação de um mundo sem voz e sem escuta, ou seja, sem nenhuma língua. Enfatizamos que quando ela muda de ideia - ou podemos dizer que quando muda de mundo - responde em português, embora não consiga compreender o outro nem ser compreendida por esse outro. Sozinha e desamparada, a criança Letícia se sente não correspondida no novo ambiente.

PESQUiSAdora: Qual a língua que você fala no sonho? Letícia: Não tem som no sonho. Parece que estão falando, mas não tem um som. É muito esquisito. Às vezes eu acho que não estão falando. PESQUISADORA: Como é o sonho que não tem som? LETÍCIA: Quando eu sonho, é o barulho de destruição do monstro. O sonho não dá para mudar. Não sei por que não tem som. PESQUISADORA: E no Japão, você sonhava? Letícia: Não me lembro do sonho. Lá no Japão só falava japonês. Não sabia o português. Sonhava falando japonês. PESQUISADORA: As pessoas falam com você no sonho? LETícIA: Elas falam, mas não sei o que elas estão falando. A minha resposta dá para ouvir, mas a dos outros não dá. PESQUISADORA: Que respostas são essas? LETíCIA: Eu não sei as respostas que falo. Eu mudo de ideia e faço outra resposta. PESQUiSADORa: Quando você dá a resposta, qual é a língua que você usa? LetícIA: Português mesmo. PESQUISADORA: O que é uma resposta? LETícia: Você faz uma pergunta e você tem que responder. Para mim, resposta é uma coisa difícil. Quando eles falam, dá para entender uma ou outra coisa. Então, é difícil de responder. 
O seu sonho no Japão passa a ter um significado marcado pela presença da língua japonesa, ou seja, a criança tem voz e não fica muda. No Brasil ocorre um encontro com o desconhecido e novamente surge o sentimento de desamparo emocional na língua de Letícia, no desencontro da comunicação cultural de dois mundos distintos: Brasil e Japão.

\section{Paisagem do sonho}

Os sonhos de Letícia revelam imagens de ansiedades persecutórias de uma fuga familiar pela sobrevivência. De acordo com o sonho de Letícia, a imagem do monstro que a perseguia e que lhe causa medo se assemelhava à imagem do ser humano. A criança traz em seu sonho uma família que está perdida em algum lugar e que, ao mudar a paisagem do sonho para o ambiente familiar que denomina de "casa", se sente internamente amparada, porém a porta que se abre nessa nova história nos leva a pensar sobre o contato de Letícia com o novo ambiente misturado com sentimentos de vida e morte. O frio e a ameaça de congelamento percebidos pela criança no sonho nos mostram que o perigo sentido por ela está no mundo externo. Essa é uma manifestação do sofrimento emocional de desamparo de Letícia, e o seu "tremer" se refere ao quanto a família estava totalmente desamparada emocionalmente e precisava ser coberta pelo calor humano.

Às vezes, eu sonho quando a minha família está em algum lugar, fugindo de alguma coisa e troca. Acho que estava fugindo de um monstro que a gente não estava conseguindo pegar e quase quando pega o monstro e vai para o outro sonho. PESQUISADORA: Como que é esse monstro? LETÍCIA: Era grande, maior que a gente, barrigudo, barba, cabelos, mãos, pernas e usava roupa. Parecia com o ser humano mesmo. Ele poderia dominar o mundo, e a gente não queria que ele dominasse, por isso que a gente quase o pegou e mudou para outro sonho. O outro sonho mudou para a nossa casa. Estava vivendo muito feliz. A porta e a janela estavam fechadas, a gente tremia de frio, a gente era muito 
feliz. Quando abriu a janela e a porta, nós morremos de frio e acabou o sonho. PESQuisadora: Como é morrer de frio? Letícia: A gente estava tremendo, que quase a gente congelou de frio.

No relato seguinte, a paisagem do sonho de Letícia representa um mundo empobrecido, em que passa a viver na escuridão, na ausência da mãe lua e do pai sol. O novo tempo vivido pela criança parece ser um "tempo de ausências".

À medida que se adapta ao o Brasil, a ausência e a privação do mundo japonês em sua vida levam Letícia a sonhar com as imagens brasileiras. Podemos pensar que as imagens japonesas, nesse momento, estão ficando "embaladas", ou seja, a criança está deixando-as de lado e podendo entrar em contato com a nova realidade.

PESQUiSADORA: Qual era a paisagem do sonho? LeTícIA: Era normal. Tudo normal. Não tinha sol e nem lua. Só tinha um céu e a noite ficava escura. PESQUISADORA: Por que não tinha nem sol nem lua? Letícia: Não sei. Só tinha um céu e a nuvem. Pesquisadora: Qual é a paisagem, do Japão ou do Brasil? Letícia: Do Brasil. Porque estou quase acostumando aqui e quase não vejo as paisagens do Japão.

Ao cursar a $5^{\mathrm{a}}$ série $/ 6^{\circ}$ ano escolar, a criança menciona que a língua portuguesa ficou mais difícil; ela não compreende os substantivos, os advérbios, a linguagem coloquial e os tempos verbais.

As matérias ficaram difíceis. A língua portuguesa que não sei. Ficou muito difícil a língua portuguesa. As palavras estão difíceis. PESQUiSADORA: Quais palavras? LetícIA: Substantivos e advérbios. Pesquisadora: Dê um exemplo. Letícia: A letra da música está na língua coloquial e a gente tem que pôr na língua certa. Não pode por "você" e "te". PESQUISADORA: Você acha que está difícil a língua portuguesa? LETícIA: Se estudar. Às vezes entendo, confundo com as palavras. Tem a língua verbal e não verbal. PESQUISADORA: Você pergunta para a professora? LETíCIA: Ela explicou e eu entendi mais ou menos. Eu resolvi estudar em casa, sozinha. 
Pesquisadora: Hoje, o que está mais difícil? Letícia: Esses dias não tenho tanto dificuldades.

Ao perguntarmos para Letícia qual a língua que considera mais difícil nas leituras que tem feito - nas revistas japonesas e nas revistas brasileiras -, ela rapidamente responde, com toda convicção, que a língua portuguesa é mais difícil e que "o japonês já acostumei. O mangá brasileiro não é igual". Valendo-nos do relato de Letícia, podemos perceber a facilidade com que ela lê as grafias da língua japonesa. Detalhista e delicada, demonstra entusiasmo ao mostrar parte do seu mundo, algo muito significativo para ela, parecendo estar tão perto e tão longe, ocupando o mesmo tempo e o mesmo espaço.

PESQUiSADORA: Qual é mais fácil, a leitura japonesa ou a portuguesa? LeTícIA: O japonês. Mesmo a história sendo igual, no mangá fica diferente. O japonês dá para aprender mais. Não consigo entender tudo em português. Às vezes pergunto para minha mãe.

Atualmente, para Letícia, as tarefas escolares vêm diminuindo e com isso consegue acabá-las mais cedo. Em seu relato, as coisas melhoraram desde quando chegou ao Brasil: "Porque comecei [a] aprender o português". O aprendizado da língua portuguesa vem acontecendo de forma rápida para Letícia, e, durante o aprendizado da língua, ela disse que não teve tempo de sentir saudades das férias. Em casa recebeu um livro complicado e difícil de língua portuguesa da mãe. Desabafa dizendo que sente raiva da língua portuguesa usada pelos internautas que acabam escrevendo errado e relaxando na escrita.

Provavelmente, com a diminuição das dificuldades escolares, Letícia sente que está conseguindo prosseguir na vida escolar com o aprendizado e conhecimento da língua portuguesa, e até mesmo se posicionar criticamente em relação aos internautas que usam de outra escrita. Portanto, a criança vem conquistando um maior domínio da língua portuguesa. 
No dia 4 de junho de 2013, a criança chega cabisbaixa em nosso consultório, expressando desânimo e sonolência. Quando a indagamos sobre a história do livro que está lendo, nos responde: "Eu tenho preguiça de ficar lendo, porque a história é sem graça".

A dificuldade da compreensão da leitura é tão exacerbada que a criança não sabe nem nos dizer o assunto da história que está lendo: "Eu não entendi nada, mas vou ler mais uma vez. É difícil de falar".

A história infantil que Letícia abraçava contra o corpo era de Nicolelis (1991), chamada O segredo da casa amarela, e nos oferecemos para lê-la em voz alta para que a criança pudesse acompanhá-la conosco. No decorrer da leitura, fomos esclarecendo para a criança alguns termos da língua portuguesa que não foram compreendidos na história. Portanto, Letícia não poderia compreendê-la sem, primeiro, entender os significados da língua portuguesa. Os termos são: "xereta", "chegar de fininho"; "tabuleiro", entre outros.

Ao interpretar a leitura para Letícia, novamente indagamos sobre o que havia compreendido da história. De forma imediata veio a sua resposta a respeito das dez primeiras páginas que lemos e explicamos para a criança. Ela consegue relatar a história que poucos minutos antes afirmava estar impossibilitada de compreender.

Destaca a criança, no trecho seguinte, que a "linguagem" foi a principal problemática quando retornou ao Brasil, porém fazer novos vínculos de amizades é considerado como "mais ou menos difícil".

Foi difícil na linguagem. Fazer amigos foi mais ou menos difícil. A prova fazia de qualquer jeito, mas ainda era $2^{\circ}$ ano $\left[1^{\text {a }}\right.$ série]. Tem prova, mas ainda não consegue se adaptar na prova. PESQUISADORA: No seu caso, não era reprovada? LETícia: Não. No caso de Eiko era difícil, porque começou no $5^{\circ}$ ano, eram palavras difíceis.

A criança Letícia, apesar de sua pouca idade, ao ingressar na escola brasileira passa a vivenciar a dificuldade do aprendizado da língua portuguesa. Demonstra preocupação com a irmã mais velha, porque Eiko não teve oportunidade de iniciar o primeiro ano escolar no Brasil, tendo que dar sequência à série escolar brasileira, que não 
havia frequentado - ou seja, a irmã Eiko, ao ingressar na escola, já pegou o "bonde andando". Novamente nos deparamos com a questão da idade das crianças imigrantes no ato da migração e que deve ser considerada um fator relevante nos processos de adaptação no momento do deslocamento. Diante de tudo isso, surge em Letícia a preocupação com o negócio da família e também com a futura estadia no Brasil.

\section{Desamparo no ambiente escolar}

O ambiente escolar promove o aprendizado e a socialização das crianças, portanto, é um espaço social. Além das dificuldades da língua portuguesa no âmbito escolar, outra preocupação é com a formação de vínculos de amizades na chegada dessas crianças que moraram em outro país.

O desamparo escolar vivido pela criança logo quando chegou ao Brasil fica evidente nos primeiros dias de aula, quando ela não consegue ter consciência de si na classe, sem o domínio da língua portuguesa e impossibilitada de ser correspondida pelas outras crianças. Em seu relato, Letícia destaca a importância da função materna, ou seja, da sua mãe como tradutora desse mundo cultural brasileiro, de poder interpretar, nomear as coisas desconhecidas, ensinando a nova linguagem que até então não era "nomeável" para a criança. Letícia se viu num mundo sem nomes e irreconhecível. Conforme foi aprendendo a simbolizar o novo ambiente, por meio da linguagem, também pôde vincular-se mais facilmente. A mãe é o primeiro objeto com o qual a criança se vincula logo ao nascer. Depois de certo tempo, a criança vai se desenvolvendo e conseguindo estabelecer novos vínculos dentro da própria família e, em seguida, com o mundo.

PESQUiSAdORA: Você chegou aqui e já entrou na escola? Letícia: Não rápido, mas eu entrei de 8 anos [ela tinha 7 anos de idade]. Pesquisadora: Como foi para você? Letícia: Pra mim era difícil ter amigos, mas a minha mãe ensina português, então os meus amigos 
entenderam muito bem. [...] Para dificuldades aparecerem eu primeiro não tinha aprendido muito o português, por isso eu chorava quando não aprendia português. Por isso quando ia na escola tinha um monte de palavras que não sabia, então e eu colocava na cabeça e falava para minha mãe. PESQUisadora: E você chorava? Letícia: Chorava quando não aprendia o português, era difícil de escrever.

Quando uma criança ingressa na escola, ela chega com uma linguagem que aprendeu com a família e que é conhecida pelas demais crianças do seu novo meio. No entanto, não foi o que ocorreu com Letícia, que chegou sem essa linguagem, mas com a linguagem japonesa, desconhecida pelos futuros colegas de classe. Assim, a formação de vínculos com outras pessoas acaba se tornando mais difícil e demorada. O sofrimento emocional de Letícia resulta em lágrimas, pois ela precisa lidar com o sentimento de impotência por não compreender a língua que lhe daria amparo emocional. O seu desejo era corresponder e ser correspondida pelos outros.

Aos 7 anos de idade, Letícia teve que passar por um novo nascimento escolar e, ainda, teria que aprender todo o beabá da língua portuguesa e da cultura brasileira.

PeSquisadora: Como foi a sua chegada à escola? Letícia: No primeiro dia, sentei na primeira carteira, não estava acostumada com as pessoas, eu não sabia quem era no lanche e no recreio. Comecei a falar com elas e elas tornaram minhas amigas. Foi difícil, porque as minhas amigas só falavam o português e eu não entendia. PESQUISADORA: Foi difícil? LETÍCIA: Eu queria falar em japonês, mas eles não entendem. Eu falava a palavra mais fácil. PESQUISADORA: Quais eram as palavras? LETícIA: A palaura era "compreensão", "ritmo" e "felicidade". Não entendia. Entendia só "feliz". PESQUISADORA: O que é felicidade? LETíCIA: Felicidade para mim é uma felicidade de vir aqui no Brasil. Feliz para mim é ir junto com a minha família e ir na escola.

"Compreensão" e "ritmo", palavras que Letícia ainda desconhecia, naquele momento era tudo que ela mais precisava receber 
das pessoas: ser compreendida e acolhida com paciência para poder acompanhar o ritmo do novo mundo.

Pesquisadora: Como você está na escola hoje? Letícia: As minhas amigas falam devagar. Dá para entender mesmo assim. PESQUISADORA: Você está indo bem nas disciplinas? LETícIA: Nas disciplinas estou indo bem. Eu tenho preguiça de estudar. Tenho que procurar as palavras no dicionário. Como tenho preguiça, não procuro depois. PESQUiSADORA: Qual é a disciplina em que tem dificuldades? LeTícia: Quase não tenho. A minha mãe me ensinou um monte de coisas, dá para entender. Quase não tenho dificuldades nas disciplinas. PESQUISADORA: O que mudaria na escola para the ajudar? LETÍCIA: Que tivesse uma professora que soubesse falar japonês e explicar para mim as palavras que eu não sei.

Os trechos seguintes mostram o estado de desamparo emocional exacerbado da criança, que acabava desencadeando sentimentos confusos, como o de sentir-se perdida na própria escola. Desejava ser compreendida e compreender o outro, por isso perdia sua própria voz. Entretanto, Letícia passa a se sentir uma "estrangeira" dentro do ambiente escolar brasileiro.

Pesquisadora: No início foi difícil para você. Letícia: Lembro que a professora falava alguma coisa para mim e não entendia nada. Pensava: "O que ela está falando?". Eu não conseguia fazer as tarefas. Pesquisadora: Você conseguia falar? Letícia: Eu não conseguia. Conseguia, mas não entendia muitas coisas que a professora e os amigos falavam. [...] PESQUisadora: Como você resolveu? LETícia: Eu fazia de qualquer jeito. Depois que consegui entender como era. A professora explicava novamente e não entendia e por isso não falava. PESQUISADORA: Por que não falava? Letícia: Porque mesmo falando. Não sei por que não falava.

Ainda: 
Pesquisadora: Era difícil ficar sem entender o outro! Letícia: Era difícil! Pensei que era outro país. Às vezes confundia as palavras. Ainda não sei os sinônimos das palavras. Antônimo é mais fácil, mas os sinônimos não. Tem que colocar o mesmo significado nas palavras. Ficava pensando: "Nossa! Todo mundo sabe! Menos eu. O que estou fazendo aqui?". Daí, nunca mais eu aprendi sinônimo. Não memorizei nenhuma coisa de sinônimo. Eu fico esperando a correção.

A criança Letícia vivencia o sentimento de "estrangeiro" no ambiente escolar, chegando a pensar que se tratava de outro país. No primeiro dia de aula de Letícia, sem os seus pais, ela tem que enfrentar sozinha novas situações em um lugar desconhecido e passa a se sentir uma verdadeira "estrangeira" na sala de aula. Diante do novo ambiente, eclodem vários sentimentos, o de vergonha, estranhamento, e a vivência de desamparo emocional. A criança perde os seus movimentos, permanecendo como uma "estátua", não conseguindo promover uma ação específica que pudesse salvá-la desse mundo inundado de sentimentos, que a deixa paralisada, enrijecida, ou seja, "robotizada" pelo novo ambiente. Portanto, a salvação foi se grudar na amiga, como um bebê que se gruda em sua mãe para salvá-lo da angústia de morte.

PESQUisadora: No primeiro dia de aula, quem estava com você? LETícia: Meus pais, eles não entraram. Tive dificuldade de entrar na aula. Tinha vergonha de falar na frente de todo mundo. Prestavam atenção em mim. Eu virava estátua. Agora dá para conversar. Quando faz trabalho tem que ficar na frente, eu não gosto. Eu viro estátua [na frente da classe]. Fiz um trabalho junto com a minha amiga, senão iria virar estátua se fizesse sozinha. PESQUISADORA: O que é estátua? LETíCIA: É difícil de mexer, falar. É como se fosse um robô. Porque é uma vergonha quando falo. Não gosto de falar na frente de todo mundo, o meu coração quase explode de tanta vergonha. Agora não passo vergonha, eu respondo quando a professora pergunta. PESQUISADORA: Foi um momento difícil para você? LETícIA: Difícil! Muito difícil! Tinha dificuldade de falar português, não sabia se ia fazer amigo. O Japão 
é mais fácil que o Brasil, porque já acostumei com o Japão. No Japão era para eu estar no $4^{\circ}$ ano e não no $5^{\circ}$ ano. Lá é um ano atrasado, não tem nono ano.

Diante da impossibilidade de fazer novos vínculos de amizade no Brasil, Letícia se sente impotente. Na escola japonesa, Letícia se identifica com uma criança chinesa, ou seja, "estrangeira", que se encontrava na mesma condição que ela. A aproximação por meio da identificação com essa criança possibilitou a formação de novos vínculos.

PESquisadora: Letícia, você teve alguma dificuldade que ficou marcada quando frequentou a escola japonesa e a escola brasileira? LETíCIA: Dificuldade. Pensei e fiquei chateada, fazer amigo. Eu não sabia fazer amigo. Quando cheguei ao Brasil, achei que ninguém quisesse brincar comigo. No Japão tem algumas pessoas assim. Pensei se eu seria amiga de alguém. Uma menina japonesa queria ser minha amiga e ela me apresentou aos amigos dela. Essa amiga foi importante para mim. O nome dela é Lin. Ela é amiga. Ela veio de outro país. Ela nasceu no Japão, só que os seus pais vieram de outro país.

Em um primeiro momento, Letícia não consegue se identificar com ninguém, o que acaba dificultando a construção de laços de amizades no Brasil.

O sentimento de impotência também fica evidente no que diz respeito à não compreensão da língua portuguesa e da cultura brasileira no ambiente escolar.

Pesquisadora: Como está? Letícia: Bem. Tem palavras que não sei, mas pergunto para a professora. PESQUISADORA: Quais são as palavras? Letícia: Não me lembro. Acho que foi... [Silêncio]. Tem palavras curtinhas. Tem palavras longas. "Arquiteto". Não sei. PESQUisadora: O arquiteto é aquele que faz os desenhos da casa, dos edifícios e outras coisas. LetícIA: Entendi. Também não sei o que é "antiesportivo". A professora disse que "anti" é contra. PESQUISADORA: 
Um jogo de futebol, quando um jogador agride alguém se torna antiesportista. Letícia: Humm. PESQUISADORA: Quando não compreende, o que sente? LETÍCIA: Eu procuro no dicionário. Mas procuro pedir para a professora e colega, porque é mais fácil, e no dicionário as palavras são mais difíceis.

\section{Férias escolares}

As crianças filhas de dekasseguis que estudaram somente em escolas japonesas, diante de outro ambiente escolar, que não conhecem, percebem-se "atrasadas" em relação ao ritmo escolar e à sua turma. Essas crianças passam a correr atrás de um tempo que não pode ser vivido por elas, ou seja, correm atrás de um "tempo morto". O tempo passado é sentido como tempo perdido e sem vida.

PESQUiSAdora: Letícia, o que você está fazendo nas férias? LeTíCIA: Estou estudando tabuada e os livros. No ano passado e retrasado eu não fazia, tinha preguiça. Eu queria brincar com todo mundo. PESQUiSADORA: Era mais difícil? LetícIA: Era! Porque tinha que fazer trabalho. Trabalho dá trabalho. Eu não queria fazer e chorava.

\section{Escola no Japão}

$\mathrm{Na}$ escola japonesa, Letícia se sentia acolhida pelo grupo, apesar de também apresentar dificuldades de compreensão na língua japonesa; não compreendia a escrita em kanji, que é a forma de caracteres mais difícil da escrita. O caminho que Letícia percorria para lidar com o "não saber" era pedir ajuda à sua mãe e à irmã Eiko, que muitas vezes não conseguiam sanar as suas dúvidas, além de tentar resolver a questão sozinha, buscando as respostas no dicionário.

Pesquisadora: Lá no Japão você tinha amigos? Letícia: Tinha muitos amigos. Eu ficava no grupo. Brincava com várias pessoas. Gostava mais de brincar com as meninas. PESQUISADORA: Quais eram as brincadeiras? LETíCIA: Areia, desenhar e parque. Tinha pessoas que 
eu não conhecia. Eu também não entendia as palavras do Japão. A palavra kanji, eu não sabia. Perguntava para minha mãe e irmã e elas não sabiam, procurava no dicionário e não encontrava. PESQUISADORA: Como se sentia quando não encontrava no dicionário? LETíCIA: Sentia que minha mãe podia ensinar japonês. A minha mãe me ensinou algumas palavras em português. "Oi”. Só entendia “oi”. [grifo nosso]

As dificuldades escolares estão presentes para essas crianças em ambos os ambientes. No ambiente escolar brasileiro Letícia está atualmente acima da média, porém chegou ao Brasil com uma única palavra no seu vocabulário de língua portuguesa e que aprendeu com a mãe: a palavra "oi".

Durante a realização do desenho do primeiro dia de aula na escola brasileira, Letícia falou sobre o ambiente escolar japonês. A criança estava aprendendo a tocar um instrumento musical chamado tamborim, que ela mesma escolheu para praticar.

No Japão, não lembro direito. No Japão, lembro das coisas do pré. Da escola não foi tanto, porque voltei rapidinho. PESQUISADORA: Que coisas são essas? LETícIA: Quando a gente brincava. Tinha muita educação física. Tinha que ir e voltar pulando coelhinho. Era muito difícil. Era estranho. Porque não era só com uma turma, era com outras turmas. Não tem professora de educação física. Era só uma professora. Eu gostava da educação física. Lembro-me das coisas de Natal. Eu ia para escola um pouquinho. A gente ia ganhar presente de Papai Noel. A professora pediu um bilhete para o Papai Noel. Eu desenhei um ursinho todo colorido. Era estranho, o corpo pintei de rosa, as patas verdes. Queria assim, porque achei que o papai poderia trazer um bem melhor que eu desenhei.

Ela continua:

A professora gostava que a gente ia para o parque, porque todo mundo brinca com todo mundo. No Japão é diferente daqui, lá tem mais horas nas escolas. No pré a minha mãe mandava comida, eu gostava 
e não conseguia comer tudo. Quando chegava em casa a minha mãe ficava brava, porque não tinha comido tudo. No primeiro ano na escola, a gente não leva almoço, a escola dava. Era público, não precisava pagar. A escola era muito grande, tinha duas quadras, tinha lugar que não podia ir, só o terceiro ano. A minha irmã tinha muitos amigos. Ela queria brincar na escola e podia. Fui brincar na escola de passar no rio e caía, chegava em casa molhada. Minha irmã dizia para minha mãe que tinha caído no rio [brincadeira de atravessar a ponte].

$\mathrm{Na}$ época que frequentava as aulas de língua japonesa no Nikkei Clube, a criança se sentia deslocada por não ter uma turma para a sua idade. Era como se Letícia ainda não tivesse encontrado a sua verdadeira turma. A criança ainda não pode encontrar o meio-termo para o seu aprendizado na língua nipônica, ou seja, nem muito fácil nem muito difícil.

PESQUisadora: No Nikkei, o nihongo está difícil para você? LETíCIA: Está difícil! Porque estou na turma especial. É turma para quem sabe nihongo. Estudo com minha irmã. Tem quatro pessoas na classe. Eu tinha que mudar de classe. PESQUISADORA: Por que não muda? LETícIA: Não quero. A outra turma da minha idade é fácil o nihongo e a outra, é difícil. Eu não tenho turma. Eu acho estranho um japonês falar o português. O tom de voz fica esquisito. PESQUISADORA: Como assim? LETíCIA: Como a palavra "exemplo", em japonês fala "exempuro". Os brasileiros também falam diferentes, porque acho que aprender japonês deve ser difícil para eles.

\section{Intervalos escolares}

Apesar de Letícia afirmar que tem muitos amigos, no relato seguinte ela está sozinha no horário do lanche escolar e justifica que o lugar onde se encontram as demais crianças é barulhento.

Pesquisadora: Como está no intervalo da escola? Letícia: Agora, estou no fundamental dois e era acostumada comer às 9 horas e agora é 
às 9h30. No pátio tem barulho e eu fico na escada comendo o lanche. A classe inteira é muito amiga.

Além do mais, os meninos falam palavras de baixo calão, e Letícia, por não saber os seus significados, recorre às amigas e as questiona sobre o que não pode ser dito em público: "Eu pergunto para as amigas: 'Por que eles ficam falando se não podem falar?’”.

\section{Escola brasileira}

A criança comenta que o mês de abril passou muito rápido e relaciona a situação com a experiência da semana de provas na escola. Expõe suas notas: nota de inglês (10) e matemática (9.0). Faz uma crítica ao professor do primo Goro, afirmando que foi injustiçado pela escola, já que o primo tirou a nota 8 numa prova e consideraram 7 porque não participou das aulas.

A instituição escolar ainda não está preparada para lidar com as crianças imigrantes. A criança Letícia, apesar de sua pouca idade, percebe a falta do olhar do professor para com o seu primo Goro no que diz respeito à problemática da adaptação da criança ao meio. Assim, distancia o aluno do professor e reforça o comportamento de isolamento da criança, que é mais um sintoma da migração.

Diante de tantas queixas, Letícia pensa que não é justo os professores ficarem dando sermões para todos por causa de alguns alunos que apresentam mau comportamento, sente-se incomodada e cansada por ter de ouvir inúmeras vezes a mesma coisa. Além do mais, sente que tudo isso atrapalha o andamento da disciplina e do futuro.

Após três anos morando no Brasil, a criança nos relata que se adaptou ao país, porém as dificuldades escolares ainda são algo que a incomoda.

Pesquisadora: Hoje, você se acostumou no Brasil? Letícia: Sim! Acostumei. Pesquisadora: Depois de três anos vivendo no Brasil, estudando em uma escola brasileira, você tem dificuldades? LETícIA: Agora tenho poucas dificuldades. Eu pergunto para a minha mãe, tia, 
avó e professora mesmo. Pesquisadora: Quais são as dificuldades? LETícia: As palavras de ciências sociais, história e geografia. Eu tenho mais dificuldades. PESQUISADORA: Em que sente dificuldades? LETÍCIA: Na palavra mesmo. Nas palavrinhas que existem. É difícil de ler e eu pergunto. PESQUISADORA: Em relação a viver no Brasil, tem dificuldades? Letícia: Não tem. Depois da escola eu vivo normal. Na escola são as dificuldades.

Como a própria criança nos relata, suas dificuldades residem nas palavras ou "palavrinhas que existem", a vida escolar representa o centro ou fonte dos seus problemas e das suas dificuldades. Caracteriza a vida fora da escola como "normal".

\section{Filhos de dekasseguis: brasileiros ou japoneses?}

A questão da identidade das crianças imigrantes no mundo contemporâneo é um assunto que tem promovido muitas discussões por parte dos pesquisadores, tendo em vista sua complexidade.

A criança Letícia define a sua identidade pelo lugar de nascimento e, por isso, se considera brasileira, como vemos a seguir:

PeSquisadora: Você é japonesa ou brasileira? Letícia: Brasileira. Pesquisadora: Por quê? Letícia: Porque eu nasci aqui.

A confusão sobre a questão da identidade de Letícia toma uma dimensão maior quando entra em contato com outras crianças na escola.

LETíciA: Minha colega me chama para aprender chinês. Eu falo que não. A outra amiga fala que não é chinesa e sim japonesa. A outra diz que é da mesma raça. Raça não é de cachorro? PESQUISADORA: Temos várias raças, como a raça negra, a raça branca. E os japoneses? Letícia: Raça amarela. Pesquisadora: Você ficou chateada? LetíCIA: Não fiquei chateada porque eles falaram de brincadeira. 
A professora que a criança acabara de conhecer, no seu primeiro dia de aula, apresenta-a para a classe como "japonesa”, e não como "brasileira”. Os traços orientais que estão estampados em seu rosto é que definem, na visão do outro, a sua identidade logo na sua chegada ao Brasil. A imagem oriental da criança se liga ao sentido de identidade. Além do mais, a própria criança, no próximo relato, se sente menos japonesa que a sua irmã.

No primeiro ano tinha a mesma dificuldade, eles pensavam que sou japonesa. E a professora me apresentou assim mesmo. Eu pensei: "Nossa! Não é assim não, no meu coração". Eu fui conversar com uma menina e quis ser amiga dela. PESQUISADORA: O que vocês conversaram? LETícia: Eu conversei de como era a escola, que eu não sabia. Ela me apresentou vários amigos. PESQUISADORA: Quando a professora falou que você era japonesa, como ficou? LETícIA: [Sorriu.] As meninas perguntaram se eu era japonesa. Eu disse que era brasileira. Não sei por que ela disse isso. Eu acho que a professora me confundiu com a minha irmã. Eu não acho isso. As minhas amigas acham que sou japonesa e continua assim mesmo.

A negação do lado japonês de Letícia se desfaz quando diz que o Japão é o seu lugar favorito e importante para ela.

Pesquisadora: O que é o Japão para você? Letícia: O Japão é meu lugar favorito, porque é um lugar importante. PESQUISADORA: Eo Brasil? LETÍCIA: É um lugar normal.

O Brasil e o Japão disputaram uma partida de futebol na Copa das Confederações de 2013. Quando perguntada para quem torceria, Letícia nem titubeou ao dizer que torceria pelo Japão. O lado japonês representa a força do mundo oriental que está internalizada na criança. Portanto, podemos pensar que é o seu lado dominante.

LETícIA: Eles estão jogando futebol? Eu torço para o Japão, porque o Japão está ficando forte. O Brasil a gente estava torcendo e ele perdeu. 
Por isso vou torcer para o Japão. PESQUISADORA: Entre o Brasil e o Japão, quem vai ganhar? LetícIA: O Japão. A minha televisão passa programa do Brasil. PESQUISADORA: Ao que você assiste nos programas brasileiros? LETÍCIA: Nenhuma coisa.

\section{Filhos de dekasseguis: o difícil retorno}

A decisão de migrar ou não para outro lugar geralmente é tomada pelos pais, que são os responsáveis pela criança. No caso de Letícia, a migração de retorno para o Brasil não ficou clara para ela. Relata-nos que ficaria no Japão por ter se adaptado à cultura e ao país. Ela não soube nos dizer precisamente quando ficara sabendo da viagem de retorno para o Brasil, se dois, três dias ou um mês antes.

PESQUiSADORA: Você foi consultada sobre o retorno para o Brasil? Letícia: A minha mãe não perguntou. Porque a gente foi direto para o Brasil. PESQUISADORA: Você queria voltar para o Brasil? LETícIA: Não sabia direito. Não queria voltar. Não entendia direito. Era bom eu ficar no Japão, porque tinha acostumado do que no Brasil.

O tempo para a criança fazer a sua própria despedida é de extrema importância para o processo de elaboração do luto. Letícia fez a sua despedida na escola com os amigos de classe, antes de regressar ao Brasil. A senhora Natsu notificou a professora sobre a viagem de retorno. Recorda-se Letícia que passou horas e horas esperando no fundo da classe os colegas arrumarem a sala para a sua despedida. Diz que recebeu uma caixa de origamis e um texto produzido pelos colegas de classe. A despedida foi sentida pela criança como uma experiência e, por isso, ficou feliz, embora sinta saudades dos amigos que deixou para trás: "Eu sinto saudades deles. Eles me ensinavam. Brincavam comigo".

PESQUisadora: Você pensa nesses seus amigos? O que pensa sobre os amigos que estão lá no Japão? Letícia: Penso! Não sei. Fico só pensando. Será que estão bem na prova? PESQUISADORA: Se fosse retornar 
para o Japão hoje, como sentiria? LETÍCIA: Acho que pularia até o céu acabar. Eu morreria de saudades. Acho que não conseguiria dormir umas semanas, porque tenho que acostumar com o quarto e a vida.

O choque cultural dessas crianças imigrantes que passaram uma temporada fora do país é intenso, e, quando retornam para o país de origem, não o reconhecem como a sua "casa". Dentro da própria casa passam a lidar com costumes e hábitos diferentes.

PESQUisadora: Quais são as dificuldades que você tinha? LeTícia: Japão e o Brasil é diferente, então eu achei no primeiro entra na casa sem sapato. Pesquisadora: Lá no Japão? Letícia: [Assente com a cabeça.] PeSQUisadora: E aqui? Letícia: Entra com sapato.

O sentimento de estranhamento da criança caracteriza um desligamento do tempo real, surgindo fantasias com futuras mudanças dos pais. Atualmente, afirma se sentir melhor diante da realidade, como se estivesse "mais direitinha".

Pesquisadora: Como que é se sentir estranha? Letícia: Antes queria estudar, a professora fala e eu penso em outra coisa. "O que eu vou fazer depois? Será que meus pais vão sair para algum lugar?” Agora, fiquei mais direitinha. [...] PESQUISADORA: Você gosta do Brasil? Letícia: Primeiro não gostava, agora gosto. Achava que o Brasil era diferente do Japão, não sabia o que era. Eu não gostava então. PESQUISADORA: Você mora na casa da tia? LETícIA: Sim. No Brasil fico chateada, porque no Brasil tem muita grama e fica coçando a minha perna.

No trecho seguinte, percebemos as dificuldades que Letícia tem enfrentado para construir novos vínculos de amizade. Seu desejo é que japoneses e brasileiros estabeleçam relações entre si.

PeSquisadora: Por que são tão importantes os amigos? Letícia: Porque não ter amigos é chato. Não ter uma conversa gostosa. Acho que é importante fazer amizades com todos. Eu acho que é importante 
fazer amizades com brasileiros e japoneses. PESQUISADORA: Hoje, você tem amigos? LETÍCIA: Tenho muitos amigos, a turma inteira e a outra também. Eu encontrei vários amigos no shopping domingo. Que coincidência! Porque são rostos conhecidos. No shopping conversa vai e demora muito. Gosto de encontrá-los na escola.

As experiências de perdas, encontros e despedidas são mencionadas pela criança como desabafos. Os laços de amizades são rompidos quando não passam a frequentar mais a mesma instituição ou migram para o Japão. A dor da separação e a vivência de luto de Letícia residem na hora do adeus.

No Japão tem uma palavra assim: pode falar em japonês e pode falar em português. Você encontra uma pessoa que você não sabe e se torna alguma coisa dela, e depois dá adeus. A gente tinha no Nikkei uma amiga, quando encontrei a amiga ela parou com o Nikkei. Os pais dela pensou melhor, ela esquecer o japonês. Aí vai melhor o português. Esse ano meu amigo do Nikkei foi para o Japão. Depois encontrei a minha avó. Você encontrou uma amiga e depois vai falar adeus para amiga.

O espaço para a realização da nossa pesquisa é visto por Letícia como o lugar para falar dos seus sentimentos mais profundos. Diante desses turbilhões de sentimentos, Letícia se sente acolhida e amparada na relação com a pesquisadora.

Estou feliz do mundo! Aqui dá para falar as coisas que não dá para falar em outros lugares. Tem muitas coisas no mundo que não são legais. O português era difícil. Tenho tristeza também com os avôs que estavam no Japão e dava terremotos e eles vieram. [...] PESQUISADORA: Como é para você vir aqui? Você me encontrou! LeTícia: Hum. Para a minha mãe não falou tudo. Eu gosto de você. As coisas que falou do Brasil, eu falo para Cizina. As coisas do coração dá para falar. Eu amo conversar com as pessoas adultas. Estou aprendendo muitas coisas com você. PESQUISADORA: Você sabe o que é psicologia? LETÍCIA: É conversar com o outro. A psicóloga da escola não escuta direito as coisas 
que tenho para falar. Não gosto de conversar com ela, fico dormindo. É uma conversa que não tem a ver com a gente. Por isso não gosto da psicóloga da escola. PESQUISADORA: Por que vai à psicóloga da escola? Letícia: Eu vou junto com as salas. Eu não faço coisas violentas. Cortar laços de amizades. PESQUISADORA: O que gostaria de falar com a psicóloga da escola? LETÍCIA: Eu gostaria de falar de sentimentos do meu coração. Não tem graça para mim. Não ensina nada para mim. PESQUiSADORA: Você gosta de vir aqui? LETíCIA: Encontrei a psicóloga mais legal do mundo. O coração tem um risquinho, não de ferida, $e$ você cura. Eu fico feliz sempre. Quando tenho coisas desesperadas e a Cizina dá para falar e dá para fazer amizades. E agora eu gosto mais da escola, desde quando eu vim aqui. Aprendi muitas coisas, tive mais amigos e não brigar com eles. Eu cresci no coração mais um pouquinho. Aos sábados e aos domingos não penteava os cabelos e nas férias era pior. Tinha preguiça. PESQUISADORA: E hoje como está a dona preguiça? LETÍCIA: Às vezes deixo de pentear. Agora é uma preguicinha. Os cabelos ficam doendo.

\section{Futuro}

A criança Letícia fala da sua incerteza sobre as realizações futuras, trabalhando com porcentagens de dar certo ou não.

PESQUiSAdora: Como você se imagina no futuro? LetícIA: Eu imagino que quero uma casa. E eu terei uma casa linda e grande. E quando crescer, ter mais anos, eu queria virar cantora, e eu não sei se vou conseguir. PESQUISADORA: Você não sabe se vai conseguir ou não, por quê? Letícia: Porque não sei do futuro, não sei se vou virar as ideias, ou se vou morrer antes de virar cantora. Tem $50 \%$ de virar cantora. Eu posso falhar na prova de cantora e ficar muito triste.

\section{Retorno ao Japão}

PeSQUiSADORA: Você quer saber alguma coisa do Japão? Letícia: O Japão está tendo terremoto? PESQUISADORA: O Japão tem terremotos. 
É um país que vive com terremotos. LETÍCIA: Quando crescer quero ir ao Japão. Fazer doações de doces e moedas. Fazer uma fábrica de docinhos para crianças normais também. Eu quero tentar qualquer coisa. No Brasil o emprego é difícil também. Eu quero ser cantora também. Eu só sei cantar música do Japão. PESQUISADORA: O que sente e pensa quando vê as fotos do Japão? LETícIA: Às vezes penso que quero voltar mais uma vez para o Japão. PESQUISADORA: O que iria fazer no Japão? LeTícIA: Brincar mais. Fazer as coisas direito. Eu queria fazer e não conseguir fazer. PESQUISADORA: Você fala que tem vontade de voltar para o Japão? LeTícIA: Muito! PESQUISADORA: Quais são essas coisas que gostaria de fazer no Japão? LETícIA: Ir para a escola e estudar direito. Fazer muitos amigos. Fazer compras nas lojas. Fazer uma casa. PESQUISADORA: Hoje você sente vontade de voltar para o Japão? Letícia: Tenho como antes. Pesquisadora: Aqui no Brasil, como se sente? LETícIA: O Brasil é o lugar que nasci. Agora estou de volta. De primeiro achava que era um lugar chato. Agora, estou gostando. PESQUISADORA: Por que achava o Brasil um lugar chato? LETícIA: Não era igual o Japão. No Japão é muito liso. No Brasil tem quebra-molas. E por isso, eu não gosto. PESQUiSAdora: No Brasil tem obstáculos que você não gosta. Qual é o seu maior obstáculo? LETíciA: No Japão a comida e a escola são gostosas. No Brasil a comida é mais ou menos. As lojas não são bonitas. Eles vendem coisas que não prestam. PESQUISADORA: Você prefere o Japão ou o Brasil? Letícia: Os dois. Acho que é legal. PESQUiSADORA: Você sente muita falta do Japão? Letícia: É. Pesquisadora: Você está sempre pensando no Japão? Letícia: Sempre. Acordo e durmo. No Japão tinha coisas legais. Tinha neve. Coisas que eu interessava. PESQUiSADORa: O que você gosta no Brasil? LETícia: Gosto dos meus amigos que são legais. Coisas para aprender. Acho que gosto mais ou menos. PESQUiSADORA: Está falando que do Brasil gosta mais ou menos. E do Japão? Letícia: Eu gosto muito! PESQUISADORA: Você pretende algum dia voltar para o Japão? LETíCIA: Quando crescer, eu quero tentar ir. Morar lá. Fazer faculdade. PESQUiSADORA: Qual a faculdade que gostaria de fazer? LETÍCIA: Não sei ainda. PESQUISADORA: Você sonha com o Japão no seu futuro. LETÍCIA: Sim. 
Os terremotos que ocorrem no Japão são vistos por Letícia como impedimento para o retorno ao Japão. Além disso, a condição de ser criança é outro obstáculo para retornar ao Japão, já que não tem como fazê-lo sozinha. A criança se queixa de ter se separado do Japão.

PESQUISADORA: Você gostaria de estar voltando para morar no Japão? Letícia: Se não fosse o terremoto. A gente sempre saía. No Brasil a gente sempre fica presa. No Japão a gente ia andando, aqui não anda mais. Fico triste dessas coisas do Japão. Das coisas que fazia. Pesquisadora: E hoje você não pode fazer mais. Letícia: Hoje, não estou com isso agora. Posso ir e não ir. Os amigos, da escola e da professora, é um pouco triste. De primeiro no Japão pensou que fosse separar do Japão. Pesquisadora: Foi difícil para você. Letícia: Foi! Eu não queria separar dos meus amigos, mesmo que não goste das matérias, é um bom lugar.

Depois de algum tempo morando no Brasil, ao perguntar à Letícia o que traria do Japão para cá, ela desabafa que a realidade japonesa não é tão fácil para a criança imigrante. As crianças não imigrantes desconhecem a realidade nipônica e idealizam o mundo japonês. Surge o olhar do outro distorcido da realidade sobre o mundo que Letícia conhece muito bem. Entretanto, Letícia vive uma ansiedade de cisão quando diz que os brasileiros são preguiçosos e sem educação.

Pesquisadora: O que traria do Japão para o Brasil? Letícia: Eu não sei o porquê. Eu não gosto que eles sabem. Acho que fui no Japão e eles ficam falando "fácil". Eles não sabem que é difícil. Eles falam que lá é legal. No Brasil, precisaria fazer coisas úteis. Eu traria comida para fazer. O doce do Brasil é doce. Eu traria os estudos do Japão para contar como foi. Eu acho que eles não vão gostar da escola japonesa. Eles falaram que não querem ir para a escola japonesa. Os brasileiros são muitos preguiçosos. Uma aluna disse-me que tinha feito a matéria e não tinha feito. São sem educação, porque a professora pede para parar e eles não param. Depois ficam chorando que não conseguiu nota boa na 
prova. PESQUisadora: Você tirou notas boas? Letícia: São mais que 7. A prova do livro tirei 5 , a nota máxima.

Na próximo trecho, Letícia inicia sua fala de uma maneira mais flexível emocionalmente, comentando que no Brasil encontra pessoas boas e ruins e que levaria os conhecimentos, comida e mangás brasileiros para os japoneses. Logo em seguida, as diferenças são gritantes entre os dois países: as ruas japonesas são consideradas tapetes e, as ruas brasileiras, esburacadas. O Japão real e o ideal parecem caminhar lado a lado; seria quase impossível distinguir um do outro.

Pesquisadora: O que levaria do Brasil para o Japão? Letícia: Levaria os conhecimentos. Como as pessoas são. Tem pessoas boazinhas e outras não. Levaria um mangá para todo mundo. Levaria comida. Ia falar que tinha muita diferença entre Brasil e Japão. As ruas japonesas são lisas e no Brasil não é bem-feita. As roupas são diferentes. No Brasil está usando roupas verdes, os japoneses não gostam. Pensava que tivesse neve no Brasil. As casas são grudadas. Nossa! Por que as casas são grudadas? Por que será que é diferente?

A fantasia de que o Brasil era um lugar deserto, inabitável, aparece no relato de Letícia quando diz ter que deixar o oásis japonês e se deslocar para um lugar sem recursos, e ainda ter que sobreviver ao inóspito. A criança faz várias comparações entre o Brasil e o Japão: critica a tecnologia brasileira, considerando-a de baixa qualidade, o mau comportamento dos brasileiros em relação aos professores e a falta de consciência dos brasileiros ao jogarem lixo na rua. Essas diferenças são nitidamente observadas pela criança.

Pesquisadora: Você se sente feliz no Brasil? Letícia: Às vezes sinto feliz. Às vezes acho chato ir para escola. Eu conheci amigos. A escola é boa. Pensei que o Brasil era um deserto. Monte de areia e muito quente. PESQUiSAdORA: No Brasil não tinha gente morando? LeTícia: Não. PeSQuisadora: Então, vocês seriam os primeiros habitantes. 
Foi na desvalorização do país presente - no caso o Brasil -, no sentimento de rejeição, que a criança encontrou uma forma de negar a nova realidade vivida por ela. Assim, consegue preservar o país ausente. "O Brasil cheira muito fedido. Não tem esgoto. Cheira xixi e cocô." Após os estados dissociativos de Letícia, a criança passa a ser mais coerente no que diz respeito à pensar a realidade brasileira: "Pensei que fosse um lugar muito chato. Depois comecei a gostar".

O medo de ser esquecida pelos amigos de classe repercute no diálogo de Letícia, logo a seguir:

Pesquisadora: Como vocee é na sala de aula? Letícia: Uma pessoa que não fala tanto. Que estuda. A inteligência é igual para todo mundo. Presta atenção nas aulas. Esqueceram de mim rapidamente. A classe toda. Só quatro amigas lembram de mim. Um exemplo, que eu não fui no encontro de vida. Eles foram, só perguntaram de mim após alguns dias. Pensei: "Nossa! A turma se esqueceu de mim!".

\section{Sentimento de vergonha}

O sentimento de vergonha de Letícia ficou transparente logo no primeiro dia de aula e está ligado ao "não saber", ao desconhecido.

Pesquisadora: O que você desenhou? Letícia: Eu tinha ido para o Brasil. A professora tinha saído da classe. Eu estava com a mala. Fiz poucas carteiras, porque são muitas. PESQUISADORA: O que você estava fazendo? LeTícia: Estava esperando a professora. Quando ela chegou, me apresentou. Eu tinha vergonha. PESQUISADORA: Por que você tinha vergonha? LETícIA: Não sabia as coisas direito, não sabia as palavras. PESQUiSADORA: Como era essa vergonha? Letícia: Vergonha de falar. No Japão não tinha vergonha dos amigos da minha irmã. Pesquisadora: Hoje, você sente vergonha? Letícia: Não. Tem algumas palavras que não sei. Às 7 tem oração e depois ficamos cinco minutos conversando na sala de aula. É muito legal. Tem um amigo que quer aprender japonês. 


\section{Urashima Taro}

A família é considerada uma estrutura física e emocional importante para Letícia. Portanto, é um meio que a ampara.

Contamos para Letícia a história de Urashima Taro. Ela prestou atenção na lenda japonesa e disse que não aceitaria ir embora para o reino das águas como fez Urashima Taro, pois nessa viagem perderia sua família.

Pesquisadora: O que pensou da história de Urashima Taro? Letícia: Nesta história, esse moço ajudou a tartaruguinha. Ele não poderia aceitar o convite da princesa. Se eu fosse ele não teria aceitado, passaram trezentos anos, vou ficar triste, não vou ter pai, mãe e irmã. Vou achar esquisito.

A criança que migra vivencia várias perdas ao se separar do convívio com a terra-mãe.

Pesquisadora: Como você resolveria? Letícia: Só iria no fundo do mar um ano; ou um dia para conhecer a princesa. PESQUISADORA: Você iria ficar pouco tempo? LeTícia: Sim. Pesquisadora: O que pensa sobre isso? LETíCIA: Eu acho que ele se sentiu muito triste. Ele viu as construções e os lugares. Eu ficaria muito triste também. Ele também tinha vida bem curtinha. Ele passou a vida no castelo da princesa. PESQUisadora: Você mudaria a história? LetícIa: Sim. Ele foi para o mar. Ele voltou de primeiro dia. Os pais preocuparam e o encontrou. Ele passou o resto da vida bem feliz. 


\section{Análise dos desenhos}

\section{Chegada ao Brasil}

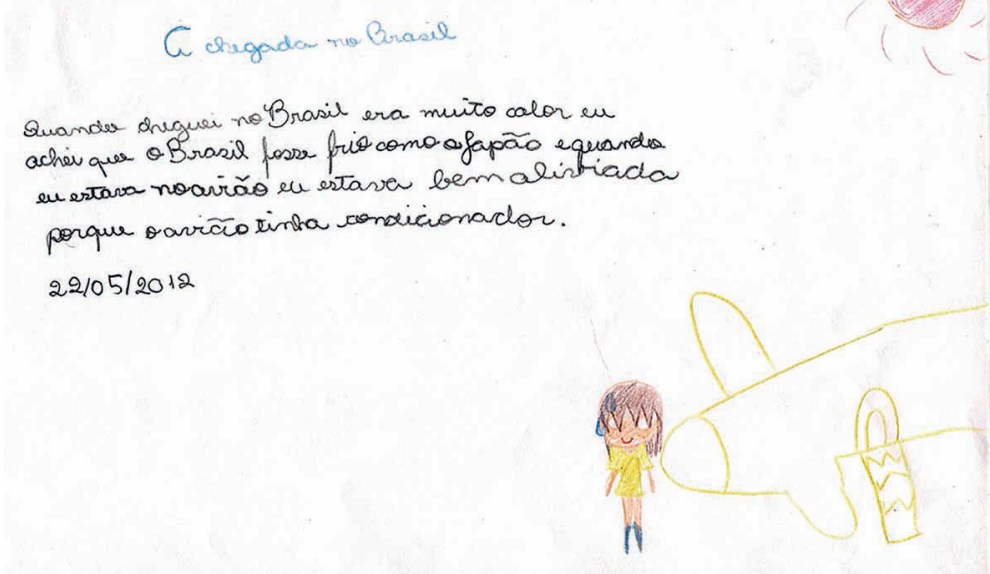

A criança inicia o desenho pela figura da menina, em seguida faz o sol que está preenchido de vermelho e depois desenha a parte da frente do avião, como se lhe faltasse psicanaliticamente a sua outra metade, mostrando uma porta aberta e as escadas. $\mathrm{O}$ sol desenhado na cor vermelha não parece ser o sol brasileiro, e sim o sol japonês. Portanto, o sol vermelho é a representação simbólica da cor da bandeira japonesa.

Ao perguntarmos o que desenhou, Letícia disse ser ela. No desenho da figura feminina tem duas gotas de suor azuis que escorrem pelos cabelos, representando o calor da chegada ao Brasil. Na figura feminina há ausência de nariz e aos olhos faltam as pupilas, estão brancos como se estivessem vazios. Seus pés estão inclinados verticalmente, como se Letícia ficasse na posição de uma bailarina clássica. Parece que Letícia não podia pisar no novo solo com os dois pés no chão ao mesmo tempo, teria que ser cautelosa na terra desconhecida; sem algumas partes de si mesma, como se os órgãos dos sentidos lhe faltassem, sem o nariz, ela acaba ficando sem direção, e sem os olhos, não enxerga a nova e difícil realidade. 
Eu estava suando com o calor do sol do Brasil. Eu tinha que tomar muita água, estava muito suado. Tinha chegado ao Brasil. O avião estava bem limpo. Quando estava no avião estava aliviada e quando saí estava com calor. No avião tem ar-condicionado. Quando ficou de dia, ficou muito calor.

O impacto da criança com o novo ambiente no momento da chegada traz um grande desconforto, o clima brasileiro é outro, diferente do Japão. Letícia faz um apontamento sobre a diferença logo na chegada, e podemos pensar que, nessa situação, ela revive o trauma do nascimento, tendo que deixar o ambiente agradável e seguro do avião, que representa a "barriga da mãe", e nascer em outro lugar, totalmente diferente do ambiente familiar.

Quando cheguei ao Brasil era muito calor. Eu achei que o Brasil fosse frio como Japão, e quando eu estava no avião eu estava bem aliviada, porque o avião tinha ar-condicionado.

Ao desembarcar do avião, Letícia se encontra sozinha, sem a família, sentindo-se emocionalmente desamparada. 


\section{Chegada ao Japão}
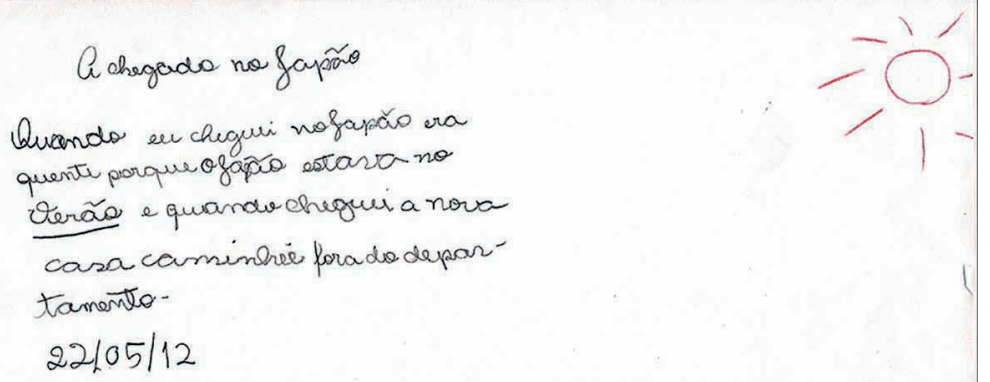

O desenho da chegada ao Japão tem a figura feminina muito pequena em relação à folha, descentralizada, do lado direito. A figura apresenta os olhos grandes e preenchidos pela cor preta. Há um sol vermelho lançando raios solares. Há a ausência do nariz e das pupilas. O sol japonês não está preenchido por dentro pela cor vermelha.

A figura feminina desenhada representa Letícia e está com os pés postos de forma horizontal, porém falta-lhe o chão para pisar, apesar de sua aparência descontraída nas terras dos seus ancestrais.

Pesquisadora: Quem é essa? Letícia: Eu. Pesquisadora: O que está fazendo? LETícIA: Eu estava caminhando junto com a família. Quando havia chegado no Japão, acho que era verão, porque era muito calor. A primeira coisa que fiz lá, fui até a casa e um depaato. ${ }^{11}$ Eu ficava brincando. Eu tinha quase um aninho e estava com sono. PESQUISADORA: Por que um sol está desse jeito preenchido e o outro não? Letícia: Porque o sol no Japão é diferente. PESQUiSADORA: Como diferente? LETícIA: O sol do Brasil é calor. O Brasil é mais quente.

11 Depaato: loja (f) de departamentos, magazine (m) (Hinata, 1998, p.60). 
Apesar das diferenças climáticas representadas pelos sóis das duas terras, o calor brasileiro é distinto do calor japonês. Para Letícia, o sol brasileiro é mais quente do que o sol japonês.

LetícIA: Quando eu cheguei no Japão era quente, porque o Japão estava no verão. E quando cheguei à nova casa caminhei fora do departamento.

A figura feminina se encontra sozinha na chegada ao Japão, porém escreve que está com a família. Apesar da pouca idade quando chegou ao Japão, traz em suas fantasias a imigração para o país de destino.

\section{Primeiro dia de aula na escola do Brasil}

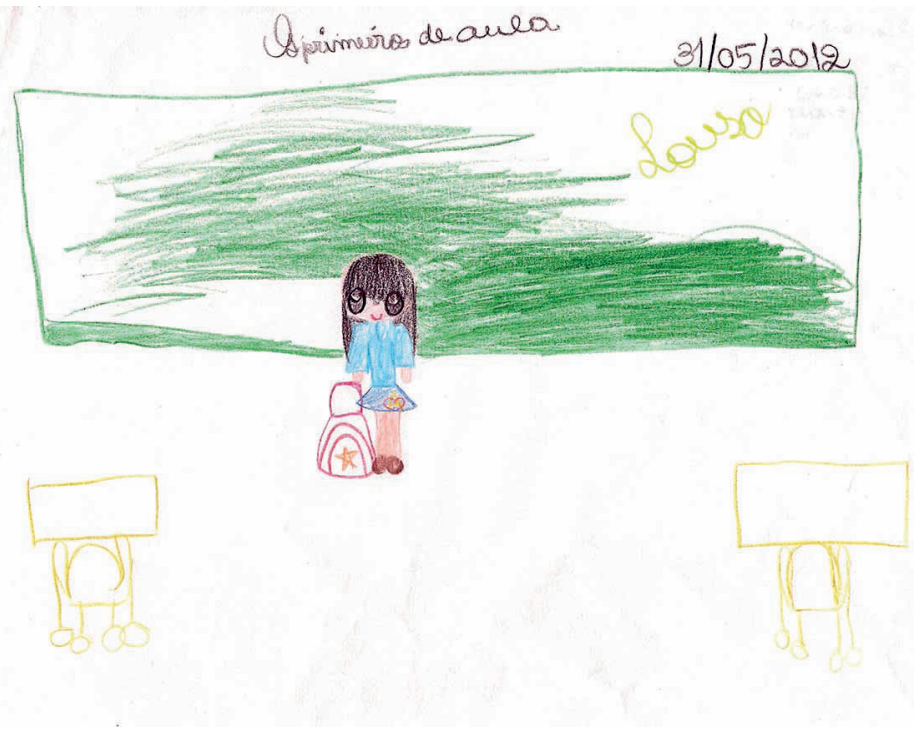

A criança Letícia desenha uma figura feminina que representa a sua chegada à escola. Encontra-se com uma mochila posta no chão. $\mathrm{Na}$ frente dessa figura há duas carteiras vazias, e atrás dela, uma lousa. Os olhos são amendoados, pretos e muito grandes, tendo uma marca que define a pupila. $\mathrm{O}$ pequeno nariz quase não se vê, fica 
misturado com os cabelos. Há ausência de chão no desenho. Mostra-se envergonhada por se sentir "estranha", diferente das demais crianças, por não conhecer as pessoas, a língua portuguesa nem o sistema escolar brasileiro.

Pesquisadora: O que você desenhou? Letícia: Eu tinha ido para o Brasil. A professora tinha saído da classe. Eu estava com a mala. Fiz poucas carteiras, porque são muitas. PESQUISADORA: O que você estava fazendo? LETÍCIA: Estava esperando a professora. Quando ela chegou, me apresentou. Eu tinha vergonha. PESQUISADORA: Por que você tinha vergonha? LETícIA: Não sabia as coisas direito, não sabia as palavras. PESQUiSADORA: Como era essa vergonha? Letícia: Vergonha de falar. No Japão não tinha vergonha dos amigos da minha irmã.

Os olhos arregalados da figura demonstram surpresa diante do novo meio. A criança percebe-se sozinha diante do desconhecido e desamparada.

\section{Desenho do rabisco}

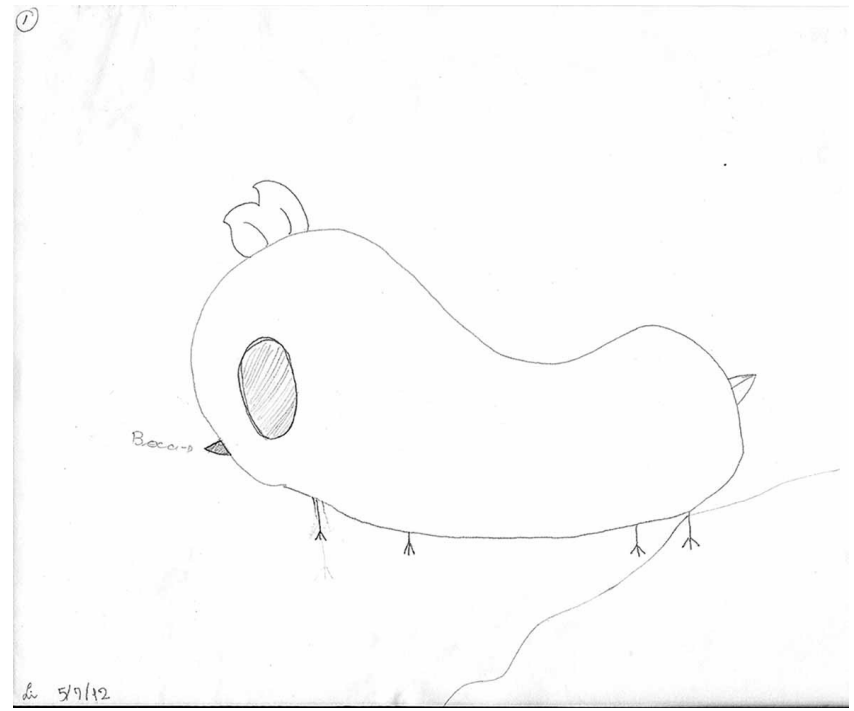


Iniciamos o desenho e a criança o terminou. $\mathrm{O}$ desenho tem a aparência de um pintinho, porém Letícia nos relata que tem dúvidas sobre se é realmente um pintinho ou uma galinha. Logo em seguida confirma que desenhou uma galinha. A figura da galinha está desenhada horizontalmente, dando para ver um dos seus lados. Apresenta um olho grande sem as pupilas, um bico pequeno, uma crista na cabeça, um rabo e quatro pés. É uma galinha mãe que está feliz por estar com os pintinhos. Letícia enfatiza, nesse desenho, a importância de estarem juntos em família e bem alimentados.

\section{Segundo desenho do rabisco}

(Q)
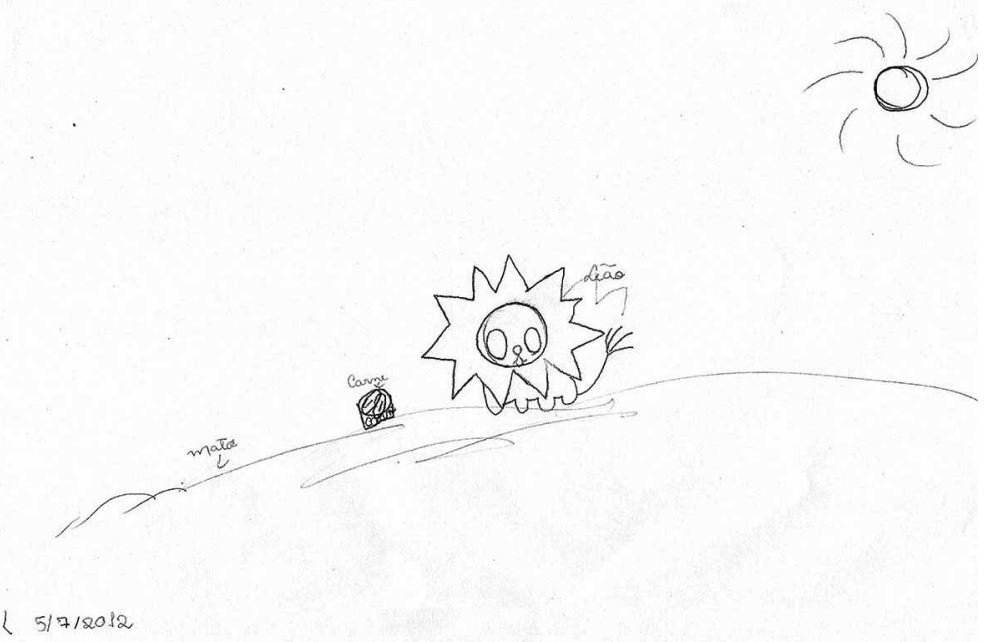

Nós iniciamos o desenho e a criança o terminou. A criança desenha um leão. $\mathrm{O}$ desenho do leão apresenta uma enorme juba, olhos arredondados mas sem as pupilas, nariz que parece uma pequena bolinha, a boca, um rabo e quatro patas. Há ausência dos pés. No desenho também há um sol e a carne está logo à frente do leão. Apresenta um traçado quase apagado, onde o leão faz o seu caminho. 
A criança relata que o leão foi capturado e depois trazido para o Brasil. Está preso no zoológico de Marília para ser visto por todos, portanto vive sozinho, sem os pais, e não tem amigos.

O desenho mostra o desamparo emocional de Letícia ao ser capturada no Japão e trazida para o Brasil. Os pais da criança representam os caçadores que a arrancaram do território japonês e a trouxeram para morar no Brasil. Sente-se sozinha, apesar de estar no meio de outros leões, por não poder depositar confiança neles e vê-los como extremamente perigosos; a criança vive uma cisão, não poderá confiar no outro; se sente ameaçada de morte, ou seja, poderá ser devorada pelos leões que estão ao seu redor. Expressa a necessidade de ter uma vida normal.

\section{Terceiro desenho do rabisco}

$12 / 07 / 2012$

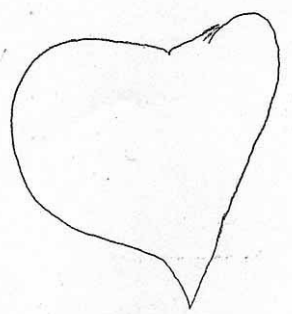

$\mathcal{L}$

A criança inicia o desenho e nós o terminamos. O desenho é de um coração. Letícia guarda nele as lembranças da família, do lugar onde nasceu, dos amigos de classe dos anos anteriores, do Nikkei Clube e da escola japonesa. 
As lembranças ocupam um espaço na mente de Letícia, pois retratam o lugar do seu nascimento e as pessoas que são importantes para ela. Lembramos que Letícia é uma brasileira nata.

\section{Quarto desenho do rabisco}

$12107 / 2012$

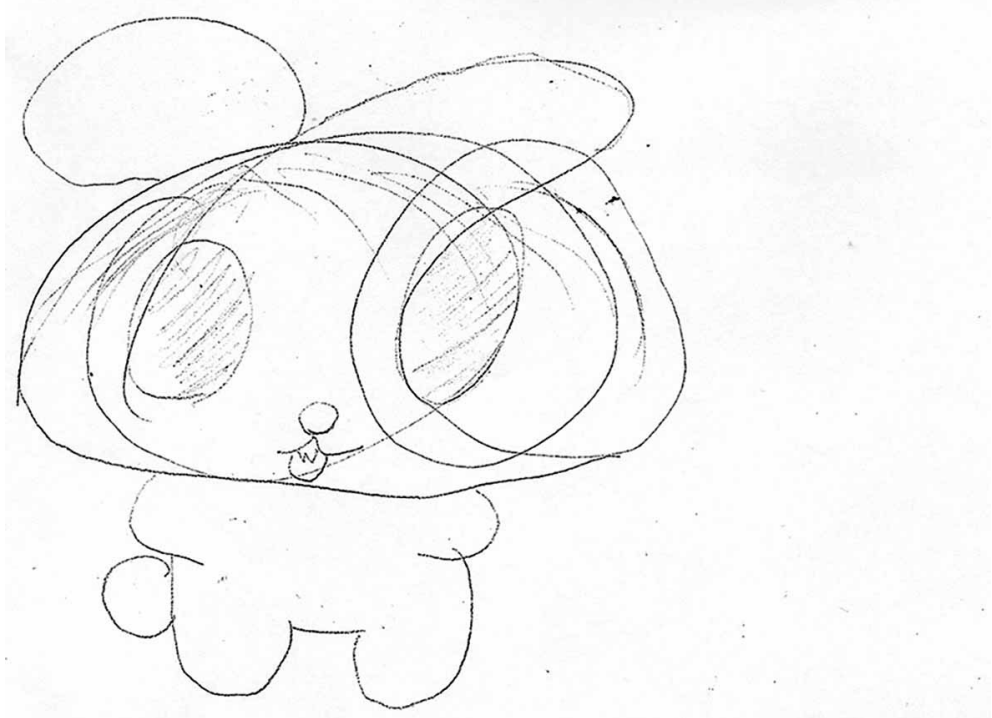

Nós iniciamos o desenho e Letícia o termina. O desenho é a figura de um urso, que tem cabelos sombreados sobre o rosto, nariz, boca, dente, olhos sombreados por dentro, orelhas, rabo, dois braços e duas pernas. Há ausência de mãos e pés. O desenho está posicionado de frente na folha de papel.

Letícia relata que é um urso de 5 anos de idade, que não tem pais, porém mostra o seu dente para que todos possam brincar com ele. Entretanto, o amigo dele é cego e quase gêmeo. Essa cegueira é resultado de um acidente de carro, no qual o amigo foi atropelado e só voltará a enxergar quando completar 10 anos. Os pais desse 
urso tiveram uma vida trágica: a mãe morreu e o pai levou um tiro de um homem.

Parece-nos que Letícia retrata o seu outro lado, acidentada, sem os olhos para enxergar o mundo; no entanto, trata-se de uma cegueira temporária, que passará quando completados os 10 anos de idade. Vemos aqui a morte dos antigos pais japoneses e a difícil orfandade que sente por viver em terras brasileiras, as quais no entanto adotou como sua nova família brasileira.

\section{Caso Goro}

\section{Vivência de desamparo de Goro com os pais}

A mãe de Goro e seus irmãos foram morar juntos na mesma casa com a família da tia materna, que é a mesma casa dos avós maternos. Enfim, todos moravam juntos na casa dos avós. O fato de os parentes acolherem a família, logo na chegada ao Brasil, evita que a família caia em desamparo emocional. O contato de Goro com os primos brasileiros permitiu que buscasse aprender e se esforçasse para começar a falar a língua portuguesa.

No terceiro contato com a senhora Haru, ela relata que seu filho Goro “ainda não está entendendo a leitura”. Faz uma crítica ao ensino e ao material didático utilizado pelas crianças brasileiras. "Quando era criança, eu não entendia. Goro está sentindo dificuldade." Perguntamos para Goro se ele está entendendo a nossa conversa e ele responde: "Eu entendi e não entendi". A senhora Haru comenta que "Ele consegue entender a base do contexto, porém os pormenores ele não entende". Um exemplo que a senhora Haru traz são as dificuldades de Goro na disciplina de geografia, não conseguindo definir o que são os movimentos de rotação e de translação. A mãe passa um vídeo para explicar a matéria. No entanto, se complica quando precisa dizer que a Terra gira em torno de si. Percebe que o filho não entende a matéria, mesmo usando o idioma japonês e fazendo gestos com as mãos. 
A mãe percebe as dificuldades do filho na aprendizagem escolar, sentindo-se desnorteada e impotente. A senhora Haru relembra o seu passado e as dificuldades escolares por quais passou, e também recorda que sofria para aprender, como o seu filho Goro.

A mãe relata que o filho está tomando medicamento homeopático porque sofre com a falta de concentração. A criança não passou por uma avaliação neurológica.

SRA. HARU: Um dia tem quantas horas? O Goro disse que tinha trinta dias. Depois disse onze horas. Nem na língua japonesa sabe a noção de tempo. No Japão ele era atrasado em relação ao tempo. Não conseguia entender dez minutos. SRA. HARU: Goro é uma criança desorganizada. Ele não lava o rosto. Ele molha os dois dedinhos e passa nos olhos. Eu ensino. Ele come e não limpa a boca.

O tempo da criança Goro não parece ser o mesmo tempo real. O tempo do Japão e o tempo do Brasil não estão conectados. São dois tempos distintos um do outro. Podemos perceber os estados confusionais e as ansiedades dissociativas.

A senhora Haru fala sobre o comportamento de Goro no Japão:

SRA. HARU: Ele era pior. Ficava no banho sentado e não tinha feito nada. Tudo que ele não gosta, se dispersa. Ele viaja. Deixei um recado para a professora, ele não entregou. Ele tem muito receio de entregar. Ele leva muito ao pé da letra. Se a professora pede para ficar quieto, ele fica parado. Ele disse que a professora havia dito: "Azar o seu”. Não entendeu o que ela queria dizer.

Entretanto, se Goro lavasse a touca da aula de arte culinária e a rasgasse, o problema seria dele. A mãe vive sofrendo por não conseguir lidar com essas dificuldades corriqueiras que o seu filho vem apresentando. $\mathrm{O}$ mundo de Goro parece estar mais no concreto, porém tem dificuldades de compreender a subjetividade da comunicação de ambas as línguas. Portanto, faltam-lhe a subjetividade da língua portuguesa e da japonesa. 
SRA. HARU: No Japão a criança foi para escola e a gente acabou falando o japonês. Eu falava o português e ele respondia em japonês. Ele não me deu opção. Na escola, no Japão, faz teste de positivo e negativo. Ele não tem iniciativa de resolver logo. Em matemática era bom.

O sentimento de culpa da mãe está em perceber a necessidade e a falta do aprendizado da língua portuguesa do seu filho Goro no retorno ao Brasil. A senhora Haru se justifica ao dizer que ficou sem opção de ensinar a língua portuguesa em casa, porque ele chegava e falava a língua japonesa.

Os pais dekasseguis, sem se esquecer de que são operários no Japão, vivem praticamente o dia inteiro nas fábricas trabalhando, pois manter o emprego é primordial para o sustento da família. Esses operários têm uma rotina diária de doze horas ou mais, e, por isso, é difícil executar a função materna ou paterna com seus filhos; eles acabam delegando-a à escola ou a algum familiar, e muitas vezes a criança, após a jornada escolar, fica sozinha em casa.

O reencontro de Goro com o seu padrasto ocorreu em meados de 2013, pois o padrasto, até então, havia permanecido no Japão. A criança diz ter ficado feliz com a volta do "pai" ao lar, mas notou algo diferente nele; disse que havia crescido, que estava "alto". Goro, por não conseguir olhar para si, projetou o seu próprio crescimento no padrasto. O casal decidiu que Goro continuaria estudando numa escola particular, porém seus irmãos menores estudariam em escolas públicas.

\section{Desamparo em relação à língua}

Essas crianças filhas de dekasseguis, ao deixarem o Japão, passam por muitas perdas, e, ao chegarem ao Brasil, perdem a sua própria língua. A primeira língua que a criança aprende é aquela que usa para se comunicar com a mãe, denominada língua materna. A linguagem materna é, a princípio, a comunicação primordial para a sobrevivência do recém-nascido. Em decorrência do desenvolvimento 
da criança, passa a aprender outras linguagens, como a língua paterna, a língua pátria e a língua cultural.

Logo na primeira entrevista com a criança Goro, a língua portuguesa foi a principal dificuldade que encontramos para tentarmos um diálogo. Em virtude da experiência da pesquisadora como dekassegui no Japão e por ter conhecimento básico da língua japonesa, foi possível estabelecer uma humilde comunicação com a criança na língua japonesa, a qual era familiar para Goro.

Ao perguntarmos em português para a criança qual era o seu nome, surgiu um longo silêncio. Goro não se expressava em português. Lembremos que, quando veio até nós, ele tinha acabado de iniciar as aulas de português na escola de idiomas. Diante de tantas dificuldades, fizemos a mesma pergunta, agora no idioma japonês, e imediatamente veio a resposta: falou o seu segundo nome, que é o nome japonês. Geralmente os pais dekasseguis registram seus filhos com o primeiro nome português e o segundo, japonês. Esses pais costumam chamar os filhos pelo segundo nome.

$\mathrm{Na}$ terceira entrevista, pedimos para que a mãe da criança Goro pudesse fazer a tradução da nossa conversa para o português. Apesar da experiência da pesquisadora, que morou no Japão durante oito anos, a vida de imigrante se resume ao trabalho, portanto ela não conseguiu desenvolver o aprendizado intermediário da língua japonesa, uma vez que o trabalho consumia seis dias na semana, e os domingos eram destinados para a realização dos afazeres domésticos, restando apenas o cansaço.

Pesquisadora: Você está tendo dificuldades aqui no Brasil? Goro [tradução da senhora Haru]: Não tenho nenhuma dificuldade. Só o idioma. Falar. PESQUISADORA: Quais as dificuldades na língua portuguesa? GORO: Dificuldade para formar as frases.

A língua portuguesa, para Goro, constitui umas de suas principais dificuldades na chegada ao Brasil. 


\section{Língua do sonho}

A língua sonhada da criança é a japonesa, conforme apontamos logo a seguir:

GORO [tradução da senhora Haru]: Falo a língua japonesa no sonho. Nunca sonhei com nada daqui. SRA. HARU: No Japão, Goro dormindo chorava muito à noite. Aqui no Brasil, ele sempre está mais alegre.

A mãe, ao perceber que tirou o seu filho do mundo oriental para morar no Brasil, justifica a decisão ao afirmar que o Brasil está fazendo bem para o seu filho, pois ele não tem chorado como chorava no Japão. Essa explicação dada pela mãe ameniza o seu sentimento de culpa em relação ao retorno para o Brasil.

\section{Paisagem do sonho}

As paisagens sonhadas por Goro são as japonesas:

Goro [tradução da senhora Haru]: Não sonho. Somente com paisagens do Japão. Tenho sonhos assustadores. Tenho medo. Sonha com uma senhora japonesa que usa botox e que ficou deformada.

O mundo da criança Goro é inteiro japonês. O Brasil não é sonhado pela criança. A criança olha para a senhora japonesa, que representa psicanaliticamente a sua mãe japonesa, como uma pessoa envelhecida, deformada e que sente medo. Como se a sua viagem de retorno para o Brasil tivesse estragado a mãe japonesa. A criança Goro fantasia uma mãe má, que assusta o seu filho imigrante porque o deixou.

O diálogo de Goro com a sua mãe ocorre no idioma japonês. A comunicação por meio da língua japonesa entre filho e mãe fortalece o sentimento de segurança sentido por Goro, de ser correspondido e não desamparado emocionalmente. 
PESQUisadora: Na sua casa, em qual idioma conversa com a sua mãe? Goro: Japonês e o português. PESQUISADORA: Qual língua sua mãe usa para conversar com você? Goro: Japonês e o português. Obaasan e Ojiichan também. O irmão só português.

A língua japonesa é mencionada primeiramente por Goro para dialogar com os seus familiares. Os irmãos menores estão aprendendo a língua portuguesa na escola. Goro está fazendo uso da língua portuguesa com os irmãos, já que eles estão no infantil e a comunicação deles ocorre no sentido mais concreto, tornando-se mais fácil a compreensão da língua para Goro.

A criança nos relata que tinha poucos amigos japoneses e que eles pediam para ensinar o idioma português: "Pesquisadora: Você ensinou o português? Goro: Peixe”.

No Japão, a criança Goro não tinha praticamente nenhum vocabulário na língua portuguesa, apesar de tentar sanar as curiosidades das crianças japonesas que demonstravam interesse pela língua de Goro.

Ao perguntarmos para a criança qual era a língua mais fácil, o português ou japonês, Goro nos responde: "Japonês. Porque é mais fácil de ler e escrever".

A dificuldade de Goro na chegada ao Brasil é não "falar" a língua portuguesa. A princípio, afirma desconhecer a língua, para, em seguida, comentar que sabia falar "um pouquinho errado o português".

PESQUISADORA: Quando chegou ao Brasil, qual era a sua dificuldade? Goro: De falar. É ruim, um pouquinho complicado para mim. Difícil de aprender. PESQUISADORA: Como fazia para falar? GORO: Falar com cuidado, pra não errar. PESQUISADORA: Quando chegou ao Brasil, falava o português ou japonês? Goro: Português. Alguns queriam que falasse japonês. Alguns meninos, né. Eu falava o japonês e português. Falava um pouquinho errado o português. PESQUISADORA: Parece-me que hoje você tem falado melhor o português? GORO: Senão, as pessoas não entendem. PESQUISADORA: Parece-me que também tem conseguido entender melhor o português. GORO: O português. 
O desejo de Goro era de saber falar a língua portuguesa antes de chegar ao Brasil para compreender e ser compreendido pelo outro. Essa criança, filha de dekasseguis, chega ao país com o Japão dentro si e com um sentimento de vazio sobre o mundo brasileiro.

\section{Desamparo no ambiente escolar}

A criança Goro fez o processo inverso das suas primas que voltaram ao Brasil. Logo que chegaram ao país, elas já foram matriculadas na escola sem saber o idioma português. A mãe Haru somente matriculou o filho depois que este foi alfabetizado na língua portuguesa numa escola de idiomas, onde a metodologia de ensino era a japonesa (embora Goro tenha cursado apenas sete meses).

Antes de Goro ser alfabetizado na língua portuguesa, os nossos diálogos eram praticamente silenciosos, e a nossa comunicação ocorria no idioma japonês.

No ano de 2013, Goro ingressa pela primeira vez numa escola particular de ensino fundamental no Brasil. Ele frequenta a $3^{\mathrm{a}}$ série $/ 4^{\circ}$ ano, após ter cursado a escola Kumon, onde teve seu primeiro contato com a língua portuguesa. A criança não pôde continuar na escola de idiomas, pois a mãe optou que Goro cursasse uma escola particular de ensino fundamental e não poderia manter as duas escolas.

Depois de ter passado sete meses se alfabetizando no idioma português, Goro, ao retornar ao nosso consultório no início de 2013 para dar sequência às nossas entrevistas, já nos mostrava que sabia falar algumas pequenas frases na língua portuguesa. Ele não era mais totalmente dependente, havia conseguido se desenvolver na língua portuguesa, embora se mantivesse uma dependência parcial. Na relação com a sua mãe, às vezes balbuciava como um bebê. Nesse dia, ele não queria entrar no consultório, queríamos sim acompanhar a mãe até o mercado. Para convencê-lo, o cumprimentamos usando o idioma japonês e ele acabou ficando a sós conosco. Foi nesse contato com a criança Goro que usamos mais o idioma português, porque ele compreendia um pouco mais a língua. Portanto, o desamparo 
emocional ocorre quando Goro faz a tentativa de se comunicar com o outro e não é correspondido, ficando sozinho em seu mundo.

A língua portuguesa continua sendo difícil para a criança, por não a entender subjetivamente. Já a matemática é a disciplina que Goro está conseguindo desenvolver com mais facilidade, porque é uma ciência exata.

Pesquisadora: Como está na escola? Goro: Mais ou menos. Porque não entendo o português. PESQUISADORA: Quando não entende o português, o que faz? GORO: Tenta falar, mas não consegue. [...] PESQUISADORA: Qual a disciplina que vai melhor? GORO: Matemática. Sou bom de matemática. PESQUISADORA: E a disciplina que vai pior? Goro: Português, porque erro bastante as letras.

Antes de Goro ingressar na escola, vivia antecipadamente angustiado por não conhecer o seu funcionamento e o novo ambiente. A criança fantasia que será motivo de riso para as outras crianças, teme se sentir desprezada no ambiente escolar.

SRA. HARU: Antes de ir para a escola, ficava falando: "Como é? Será que as crianças vão rir de mim?". Ele voltou contente, porque todos mostraram a escola para ele. Antes de começar as aulas conversei com a professora e expliquei como meu filho era. Ele é muito ingênuo de tudo. Tem coisas que ele acredita. Ele não é maturo?

A preocupação da senhora Haru com a condição do seu filho Goro na escola é imensa, e, por isso, decidiu conversar com a professora e informá-la da ingenuidade de seu filho. Nas entrevistas com os pais dekasseguis, eles comentam que as crianças que moram no Brasil estão na frente em quesito amadurecimento, esperteza e malícia, diferente das crianças japonesas, que prolongam o tempo de infância.

Para a criança compreender algumas disciplinas escolares, é necessária a compreensão da língua portuguesa. 
SRA. HARU: Ciências não consegue entender. O inglês está aprendendo rápido. História e geografia estão com dificuldades. O português estava indo, agora com os verbos fica perdido justamente com o passado, presente e futuro, que mexe com ele. Ele pergunta: "Por que o português tem tantos verbos?".

No aprendizado do idioma japonês, Goro conseguia conjugar os tempos verbais corretos. Entretanto, no Japão a criança encontrava-se num "ritmo da falta", ou seja, faltava leitura japonesa para desenvolvê-lo na língua.

SRA. HARU: No japonês ele consegue pôr os verbos no tempo. A professora japonesa dizia que faltava leitura. Ele procurava livros com imagens no Japão. Fala que vai demorar de ler. O português, fala que não sabe escrever e que prefere falar?

Goro queixa-se porque ainda não conseguiu aprender a língua portuguesa nem escrever as palavras que são extensas e as que são acentuadas. Parece-nos que Goro ainda não conseguiu compreender as regras da nova língua. $\mathrm{O}$ medo que a criança sente ao lidar com o "não saber" mostra que se ela depara com a sua própria impotência diante do desconhecido mundo escolar. Além do mais, a criança percebe que não é capaz de agradar a mãe e faz uma comparação da sua vida escolar com a vida escolar da mãe, considerando-a excelente aluna, uma das primeiras da classe. A criança se sente na obrigação de ficar entre os primeiros alunos da classe, pois, se tiver um bom desempenho no aprendizado escolar, ganhará uma bolsa de estudos e livrará a mãe dos seus gastos escolares. Dessa forma, a criança tentará fazer a reparação com mãe, que deverá ser reconquistada por Goro se ele se mostrar bem-sucedido em seus estudos. A criança sente muita culpa por não alcançar bons resultados escolares.

Pesquisadora: Goro, você estudou no Kumon. O que aprendeu? Goro: Letras, palavras e comprar. PESQUisadora: Como foi aprender as letras e as palavras na escola Kumon? GORO: Foi legal! Porque 
aprendi bastante. PESQUISADORA: Você está podendo falar o português. O que pensa sobre isso? GORO: Matemática hoje está bom, porque aprendi no Kumon. PeSQUiSADORA: E o português? Goro: Está indo mais ou menos, porque eu erro palavras. PESQUISADORA: Quais são as palavras? Goro: Palavras compridos e de acento. PESQUISADORA: Você lembra alguma palavra para me dizer? GORO: Paralelepípedo. PESQUISADORA: Essa palavra parece um palavrão! Goro: [Ri.] Essa palavra não consegue escrever. PESQUISADORA: O que sente quando não consegue? Goro: Sente com medo. PESQUISADORA: O que pensa? Goro: Que vai errar. PESQUisadora: O que poderá acontecer se errar? GoRo: Que a professora vai ficar brava. PESQUISADORA: Você tem sentido muito medo na escola? GoRO: Tem. PESQUISADORA: Qual é o seu maior medo? Goro: Texto. PESQUISADORA: Então, o texto lhe assombra. Você sabe que é assombrar? GORO: Não. PESQUISADORA: É ficar com muito medo. GORO: Porque a minha mãe fica muito brava. Porque a minha mãe tirava nota mais ou menos e depois tudo dez. PESQUISADORA: Parece-me que sua mãe lhe cobra. Goro: Ela era $2^{\circ}$ e $1^{\circ}$. PESQUISADORA: O que pensa sobre isso? GORO: Que é bom. Aí, não precisa mais pagar a escola. PeSquisadora: Como assim? GoRO: Se ficar em $1^{o}$ não precisa mais pagar a escola. PESQUISADORA: Você está me dizendo que se ficar em primeiro lugar da classe não pagará mais a escola? GORO: Hum.

A criança vem mostrando insatisfação por não ter atingido notas melhores nas avaliações escolares. Goro tirou a nota 9.3 em inglês, porém em língua portuguesa conseguiu 7.3 pontos, que está acima da média; justifica que se saiu mais ou menos na avaliação, porque está um pouco acima dos 6 pontos, que é a média para a sua aprovação. A pontuação de 5.8 ficou para a disciplina de ciências, a qual nomeia nota ruim, por estar abaixo da média escolar.

Pesquisadora: O que você não entendeu em ciências? Goro: Não entendeu as palavras e os bichos. Palavras que põem acentos. Do Japão é mais fácil. PESQUISADORA: Parece-me que as palavras portuguesas têm mais acentos. Quando não entende, o que sente? GORO: Sinto com medo de não saber escrever. De não entender. 
O medo de não saber escrever ou de entender refere-se ao medo de ficar impotente diante da vida. A criança teme viver uma eterna castração.

\section{Escola japonesa}

Pesquisadora: Você gosta dos games brasileiros? Goro: Gosto mais do Japão, porque faz barulho. A quadra é grande. [Ele quis dizer que a tela desses jogos japoneses é grande.]. A minha escola é grande no Japão. Até o sexto ano, tem sexto andar. PESQUISADORA: No Brasil, como está a escola? GORO: Está um pouco melhor. Eu fico mais conversando. Pesquisadora: Como é a escola? Goro: É pequeno, porque a minha mãe escolheu. No Japão tinha outro escola, mas eu mudei de escola. Tinha artes e ideogramas, gramáticas. Tem laboratório. Ainda não faz no Japão. [...] PESQUISADORA: Foi difícil aprender matemática? Goro: Foi difícil, porque não sabia fazer conta de cem. A divisão não sabia. [...] Pesquisadora: A prova de português? Goro: Acho que foi ruim, porque tinha bastante erro. Fiquei com medo, né. Não entendeu as palavras.

A matemática é uma ciência exata, por isso é uma linguagem própria e completamente diferente da língua portuguesa. Apesar de Goro, num primeiro momento, ter dificuldades com o aprendizado da matemática, ele consegue, após um tempo, compreender a lógica dessa ciência. O não conhecimento da língua portuguesa dentro do ambiente escolar, por sua vez, acarreta o desamparo emocional na criança, uma vez que ela não consegue comunicar o que sente para a família, para que possa ser ajudada e se sentir satisfeita em suas necessidades. Surge o medo de errar no aprendizado escolar, como se tivesse que se esquivar do sentimento de impotência.

Filhos de dekasseguis: brasileiros ou japoneses?

O nome brasileiro/japonês dessas crianças filhas de dekasseguis mostra que os próprios pais têm dificuldades em definir a 
identidade de seus filhos: brasileiros ou japoneses? Cria-se uma ambivalência identitária, gerando um sentimento de não pertencimento nessas pequenas crianças. Ao contrário, poderíamos pensar numa soma de ambas as culturas, já que estamos lidando com crianças híbridas.

Ao perguntar para Goro se ele é brasileiro ou japonês, ele responde: "Brasileiro, porque nasci no Brasil, na cidade de Bastos".

A identidade está sendo definida pelo lugar de nascimento. Será que Goro se sente brasileiro ou japonês?

Pesquisadora: Para quem está torcendo, Brasil ou Japão? Goro: Eu falei do Brasil. Eu estou morando no Brasil. Já na verdade, eu sou brasileiro. O meu pai gosta de assistir. Eu acho que o Japão fez um gol. Pesquisadora: Quem ganhou o jogo? Goro: Brasil. Não sei. O Brasil ganhou de 2 ou 3. O Japão fez 1 ou 2.

\section{Filhos de dekasseguis: o difícil retorno}

Na primeira entrevista com a criança Goro, tivemos a sensação de que estávamos no Japão. Ele compreendia somente o idioma japonês. A língua portuguesa parecia nunca ter sido usada por ele e era vista como algo estranho, pois era desconhecida pela criança.

Nesse dia, a criança expressou o desejo de retornar para o Japão. Depois de três semanas e com novos acontecimentos ocorridos no Japão, a criança diz não pensar num futuro retorno para lá, como mostra o relato seguinte:

Pesquisadora: Você veio para o Brasil. Você pensa em retornar para o Japão? GORO: Não. Lá tem terremotos e tsunamis. Eu não quero morrer lá. Sinto falta dos brinquedos. Eu tinha amigos lá.

Os empecilhos naturais, como os maremotos e terremotos citados pela criança Goro, são motivos para não pensar num futuro retorno ao Japão, caracterizando obstáculos ou impedimentos para a volta à "Terra do Sol Nascente". Motivado pela pulsão de vida, 
Goro foge da morte. Surgem o sentimento de insegurança e a ameaça de morte em terras japonesas.

A criança menciona a falta que sente do ambiente em que vivia. Além do mais, os amigos e os seus brinquedos não estão mais em seu entorno. A criança (e)imigrante, ao se deslocar para outro país, passa pelo processo de separação, vive "enlutada", tentando elaborar as suas perdas.

Pesquisadora: Como está o Brasil para você? Goro: Bom. PesQUISADORA: O que você gosta? GoRO: Comida, arroz com feijão, frangos e carnes. Pesquisadora: Você tem saudades do Japão? Goro: Não tem muito. Mais ou menos. PESQUISADORA: Do que sente mais saudades do Japão? Goro: Da guerra que vai começar. Gostava dos games e dos brinquedos. São chiques e duros.

A senhora Haru fala do contato do filho Goro com a pesquisadora:

SRA. HARU: Ele voltou contente daqui, dizendo que conversou com você. Com a professora não conversa. Acho que ela brinca demais. A visão de professora para ele é bem diferente. Tem ser mais madura. Ele dá muito crédito para essas pessoas.

Como Goro não compreende o comportamento da professora, ele acaba se isolando na sala de aula.

O futuro é visto como algo ameaçador para a criança, como se enxergasse um acidente em sua vida. Logo após, fica em silêncio. Goro brinca com o jogo da vida, tendo que aprender as novas regras desse jogo para ultrapassar os obstáculos encontrados em seu caminho.

Pesquisadora: O que pretende fazer no futuro? Você sabe o que é futuro? GORO: Sim. Tenho medo. Porque vai bater o carro. PESQUISADORA: Fale um pouquinho sobre isso! Goro: Estava vendo meu avô dirigindo o carro. Todo dia que vai na escola. 
A comunicação do retorno de Goro ao Brasil foi feita pela sua mãe. A criança sentiu medo em deixar a terra oriental, já que era a terra conhecida por ele. Traz em suas lembranças o medo que sentiu na chegada ao Japão e do futuro retorno para o Brasil. O Brasil era um lugar estranho para Goro, que também não conhecia os seus parentes brasileiros.

Pesquisadora: O que pensou quando sua mãe lhe contou que iria voltar para o Brasil? GORO: Eu ficou com medo. Quando tinha 2 anos fui para Japão e não conheceu nada. Eu ficou com medo. Pesquisadora: Com medo do quê? Goro: Da escola. Todo mundo brigou. Pesquisadora: Alguém brigou com você lá? Goro: Não! Eu era novo. Pesquisadora: O que sentiu? O que pensou? Goro: Senti um pouquinho de medo. Ainda não conhecia meu tio, minha tia e meu Brasil.

O retorno para o Brasil não era discutido em família. As diferenças entre os dois países são encontradas na nova realidade cotidiana. O contato de Goro com a nova cultura faz com que possa ir se adaptando ao novo ambiente, tornando-se mais acessível.

Pesquisadora: Sua mãe falava do Brasil com você? Goro: Não falava do Brasil. Enfatiza que no Japão pode jogar o papel higiênico no vaso sanitário e aqui no Brasil não se usa fazer isso. Que não sabia disso. PESQUISADORA: Parece-me que está aprendendo a fazer novas coisas aqui. Goro: Ai vai ficando mais fácil. [...] PESQUISADORA: Você sabe por que voltou do Japão? GORO: Vai ter guerra, se ficar vai morrer. Os coreanos vão fazer um míssil para explodir tudo. PESQUISADORA: Por que você voltou do Japão? GORO: Também por causa da guerra. Meu pai demorou bastante para vir.

A viagem de retorno de Goro ao Brasil encontra-se cheia de fantasias misturadas com um toque de realidade. O Japão tem se sentido ameaçado pelos mísseis coreanos, uma vez que a Coreia do Norte testa seu arsenal bélico em direção do arquipélago japonês. No 
entanto, Goro cria a fantasia de ter retornado para o Brasil por causa de uma possível guerra que poderia causar sua morte.

\section{Sentimento de vergonha}

O sentimento de vergonha não está presente apenas nos diálogos das crianças filhas de dekasseguis; a senhora Haru também diz sentir vergonha e medo de cometer alguma falha.

Pesquisadora: Você tem amigos? Goro: Todo mundo! PesquiSADORA: No intervalo, como que é? GORO: Conversa pouco. Eu tenho vergonha. Vai rir de mim. PESQUISADORA: Por que pensa que as pessoas vão rir de você? GoRO: Penso assim.

A senhora Haru idealiza os japoneses nativos como aqueles que não sentem vergonha.

SRA. HARU: Os japoneses não têm vergonha. O fato dele não ser japonês mexeu com ele. Tem esse complexo de inferioridade. PESQUISADORA: A vergonha está nos descendentes de japonês? SRA. HARU: A gente repara que as crianças japonesas questionam os professores. Goro: Ainda não tem isso.

Para a senhora Haru, o sentimento de vergonha é:

SRA. HARU: Estar na frente de todo mundo e falar errado. Nossos termos são antigos. Eles usam muitos termos ingleses. Penso: "Será que falo? Ou não falo?". PESQUiSAdora: Você fica na dúvida? SRA. HARU: Sim. Penso: "Será que falo? E se falar errado?". Japonês é tudo sistemático. Às vezes você não se encaixa aí. Nós somos descendentes e somos criados nesses sistemas. Japonês é cheio de pormenores. Tudo tem uma palavra para usar. Eu ficava me perguntando: "Ai? E agora? O que falo?" Preferia nem falar. Tem coisas que a gente pergunta e é falta de educação. O brasileiro pergunta. Eu me preocupo falar coisas que ofendem. O jovem japonês é mais fácil falar. Com os mais velhos é 
melhor não falar nada. Com a professora japonesa eu falava, não tinha problema. Ela entendia, era uma pessoa de mais ou menos acima dos 50 anos de idade.

O sentimento da senhora Haru no diálogo anterior não parecia ser de uma brasileira imigrante diante dos japoneses. A senhora Haru parecia ser uma japonesa que não sabia falar corretamente a língua pátria e se sentia envergonhada por não corresponder na forma verbal nipônica. Surgem sentimentos de ambivalência sobre sua própria identidade.

O sentimento de desistência é denominado por Goro como "preguiça", diante das dificuldades escolares que vem enfrentando. Ele passa se a autoagredir, se desvalorizando como preguiçoso.

PESQUiSAdora: Você gosta de algum livro em português? GORO: Não. Tem vez com "prigui”. Não gosto muito. PESQUISADORa: Tem vez que sente preguiça? GORO: É. PESQUISADORA: Você acha difícil ler um texto em português? GORO: É. Porque não sei muito palavra. PESQUISADORA: Parece-me que não sabe compreender o que está escrito. É isso? GORO: [Assente com a cabeça]. PESQUISADORA: Quando não consegue compreender, qual é o seu sentimento? GORO: Vergonha. PESQUISADORA: O que é vergonha? GORO: Todo mundo ri. PESQUISADORA: Isso está acontecendo? GoRO: Não.

A vergonha também acaba impedindo a formação de novos vínculos de amizades. Ressaltamos que, no início de 2013, a criança Goro estava iniciando o ano escolar no Brasil, já havia se alfabetizado, porém apresentava muitas dificuldades de comunicação na língua portuguesa. Será que a falta de conhecimento na língua portuguesa dificulta a formação de novos vínculos?

GORO: No começo do ano não perguntava, porque tinha vergonha. Pesquisadora: O que é vergonha? Goro: De falar com os amigos. PESQUISADORA: E agora? GORO: Eu converso com meu amigo e o outro não. Tenho dois amigos. A gente conversa de game e pega-pega. 


\section{Urashima Taro}

A história de Urashima Taro é conhecida por todos que estudam em escolas japonesas. A criança Goro diz conhecê-la, porém, de forma direta, diz não desejar mudar nada nela. Cabe destacarmos o fato de que Goro parece ainda não ter pensado no tempo e no espaço.

\section{Análise dos desenhos}

\section{Chegada ao Brasil}

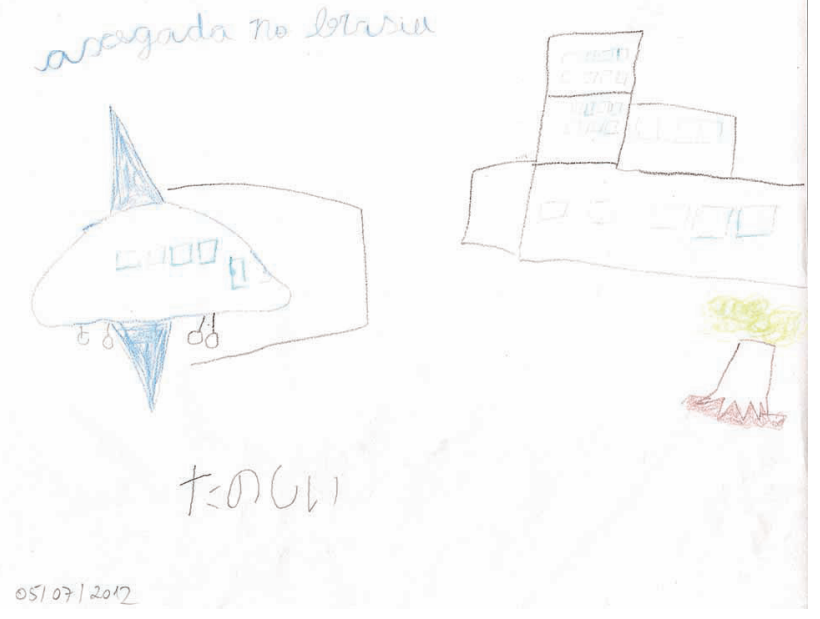

Pedimos para a criança desenhar a sua chegada no Brasil. Fez-se esse pedido na língua japonesa. Ele desenha uma árvore: chão, raízes, tronco e a copa sobre o tronco, do lado direito da folha de papel, e um avião, o céu e um prédio com várias janelas dispostas horizontalmente. Ele escreve no desenho: "axegada no brasiu" e também a palavra tanoshii, ${ }^{12}$ que está em hiragana e significa agradável e feliz.

12 Tanoshii: [adj] agradável, feliz, apreciável, alegre, contente (Ohno, 1989, p.759). 
Na chegada ao Brasil, Goro não desenhou o chão, como se no momento não pudesse se sentir em terra firme. Não há nenhuma figura familiar que o acolhe, nem sua própria figura foi desenhada. Ele chega ausente em terras brasileiras.

\section{Chegada ao Japão}

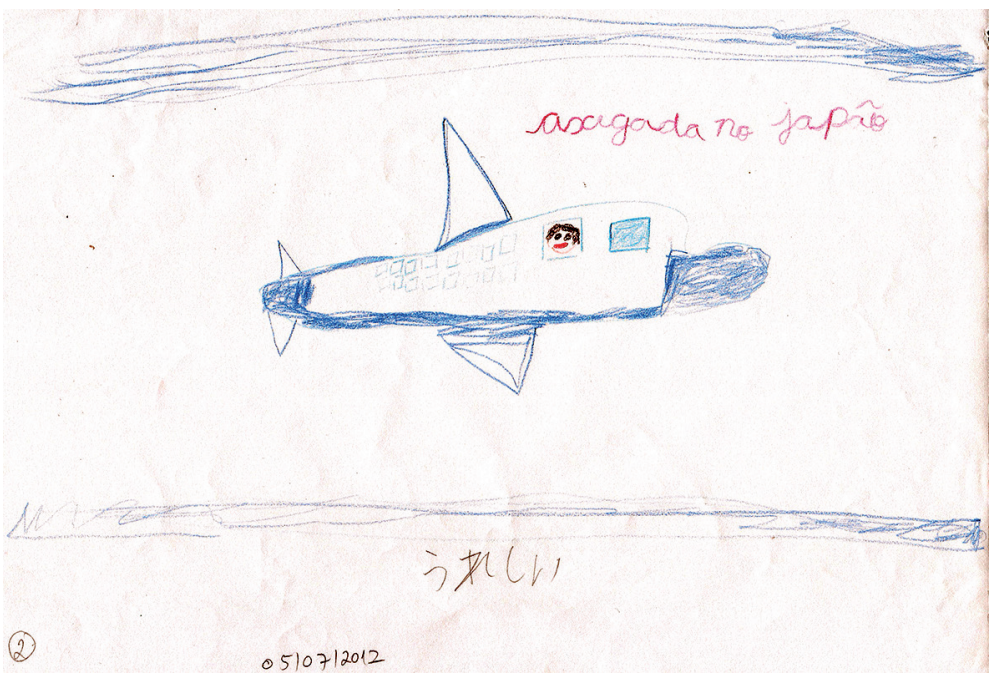

O desenho da chegada ao Japão traz um avião com várias janelas e a figura da cabeça da criança estampada na janela do avião. Seus lábios estão vermelhos, os olhos preenchidos com lápis preto, mas o nariz está ausente. Fez o céu e a terra. Ele escreve no desenho: “axegada no Japão" e também a palavra ureshii ${ }^{13}$ em hiragana, que significa estar contente.

Apesar dos quase 2 anos de idade, Goro, ao representar a chegada ao Japão, traz o céu azul e a pista ou chão azul. Parece-nos que ele tinha onde pisar.

13 Ureshii: [adj] estar feliz, contente, satisfeito, alegre (Ohno, 1989, p.855). 
A sua figura está desenhada na janela, parecendo ser de uma pessoa mais velha e não de Goro. Talvez ele tentasse olhar pela janela o encontro com o novo mundo oriental.

O avião é um símbolo fálico, ele está dentro de uma grande potência; no entanto, há a ausência do nariz na figura. A criança fica dentro do avião, não sai para fazer outro nascimento em solo da mãe japonesa.

A criança Goro, apesar de escrever que está feliz na chegada ao Japão, não desenha nenhuma figura familiar para ampará-lo. Ele se sente sozinho e pela metade. Apenas a cabeça está visível.

\section{Desenho da chegada na escola de idiomas}

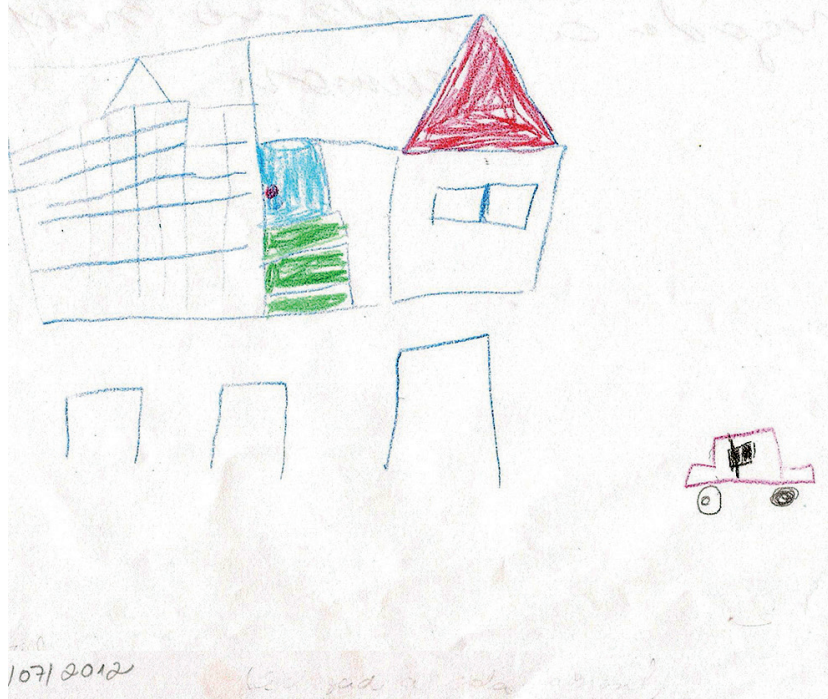

A criança desenha uma casa lateral, com janela, porta, escadas e vários traçados quadriculados em outra sala. Fez três estacionamentos para carros e um veículo passando na rua. É como se a casa desenhada pela criança estivesse voando, sem chão. O desenho mostra que a criança vive muitas fantasias, porém mostra que o seu eu precisa se organizar. 


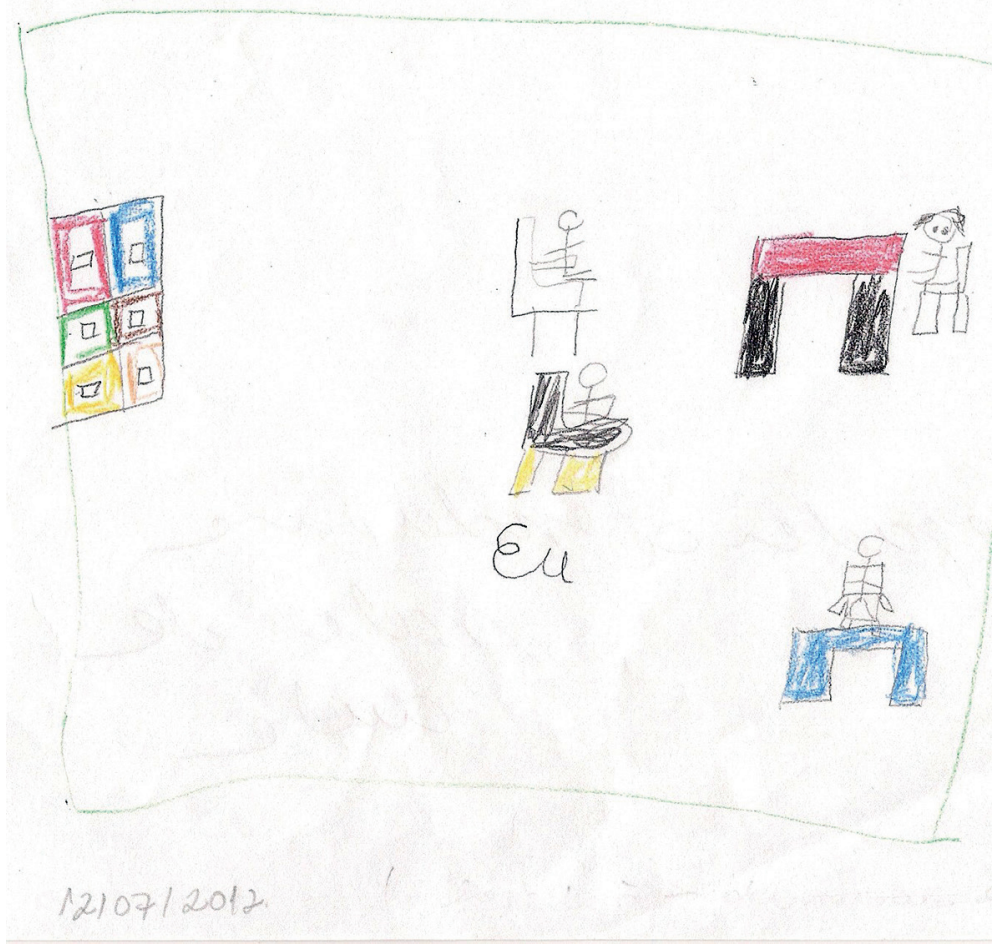

No segundo desenho, Goro desenha a escola de idiomas por dentro. Nele temos a figura da professora na frente da sala de aula e mais três alunos. Seu desenho está centralizado entre as duas carteiras. Encontra-se sentado na cadeira, onde está escrito a palavra "Eu". No fundo da sala há um armário colorido. Todas as figuras estão dentro de um cercado e são traçados primitivos, parecem ter sido feitos por crianças menores. Esse cenário desenhado por Goro é uma ressonância do seu mundo interno, que se encontra num estado de regressão e privação. 


\section{Primeiro dia de aula na escola de ensino fundamental}

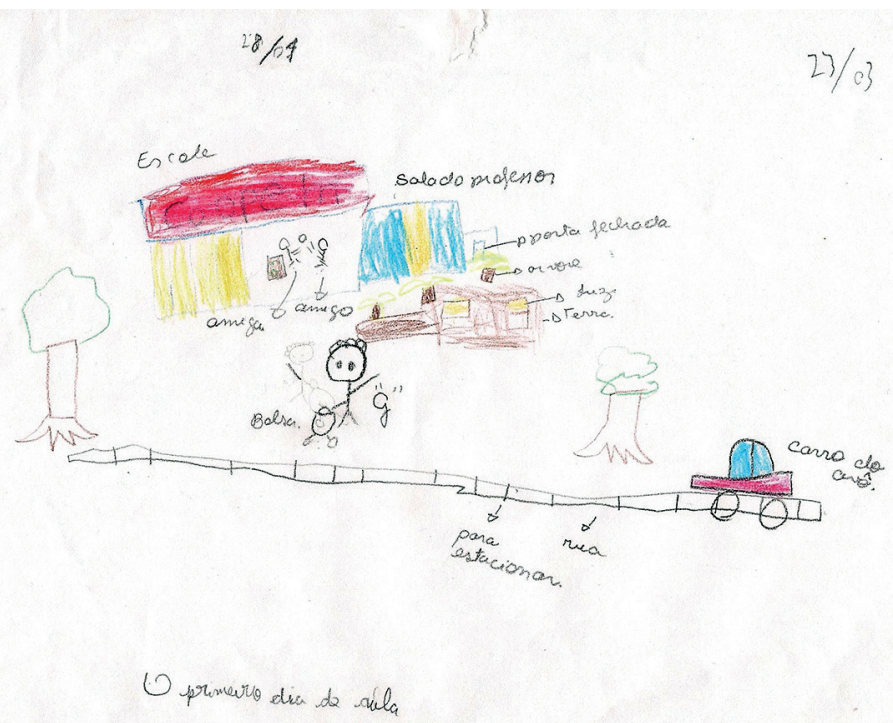

A criança Goro inicia o desenho pelo lado esquerdo da folha de papel. Desenha a sua escola. Em seguida, faz o desenho de uma árvore e a segunda árvore do lado direito. Depois escreve o nome da escola no prédio. Faz desenhos na cor marrom e que nomeia "terra", "luz" e "árvores". Logo abaixo, faz uma figura humana muito pequena e usa a borracha para apagar o desenho. Novamente desenha a figura humana um pouco maior com uma bolsa, a quem dá o seu nome. Desenha dois amigos jogando bola na quadra. Por último, uma rua, os estacionamentos e o carro que o avô materno usa para levá-lo à escola.

Ao chegar à escola, Goro está sozinho para carregar a sua bagagem. Nesse desenho, a criança Goro mostra que está do lado de fora das brincadeiras com os amigos. As figuras humanas desenhadas pela criança apresentam formas rudimentares diante da sua idade. São figuras que têm uma cabeça, tronco e membros. As figuras que 
representam os dois amigos não têm olhos, orelhas, nariz, boca e cabelo. No desenho que representa Goro, há ausência do nariz, da boca e das orelhas, ou seja, não possui os órgãos dos sentidos. Parece-nos que Goro vive grandes perdas, como se lhe faltasse a audição, a direção e a comunicação, ficando somente com a visão do seu entorno. Os amigos parecem ser surdos, mudos, sem faro e sem visão.

Pesquisadora: O que você desenhou? Goro: Eu indo para escola. [As árvores ficam fora da escola. A luz e a terra são para ir à noite para a escola. Disse-nos que a porta está fechada porque o professor a fechou.] Pesquisadora: Como é o seu professor? Goro: Mais ou menos. Pesquisadora: O que é mais ou menos? Goro: Bravo. Pesquisadora: Ele é bravo com você? Goro: Pouquinho. PESQUISADORA: O que ele fala para você? GoRO: "Presta atenção!" PESQUISADORA: O que sentiu? Goro: Assustou. Pesquisadora: Falou alguma coisa para ele? Goro: Não. Assustou. Pesquisadora: O que você pensou que fosse fazer? Goro: Brigar. Pesquisadora: Mas ele brigou? Goro: Não. [...] Goro: Está carregando a bolsa para ir à escola. Já está indo à escola. Amiga e amigo estão na quadra brincando de bola. Eu estou carregando a bolsa e logo vou chegar à escola.

Esse desenho feito pela criança Goro mostra o desamparo emocional na escola e na sala de aula. Percebemos nele as ansiedades persecutórias que a criança sente em relação ao ambiente escolar. O comportamento do novo professor, bem como o tom de sua voz e a forma de ensinar, soam estranhos para Goro. Portanto, surge o medo de ser destruído na condição de aluno e de não conseguir corresponder à autoridade. 
DESAMPARO PSÍQUICO NOS FILHOS DE DEKASSEGUIS...

251

Desenho do rabisco

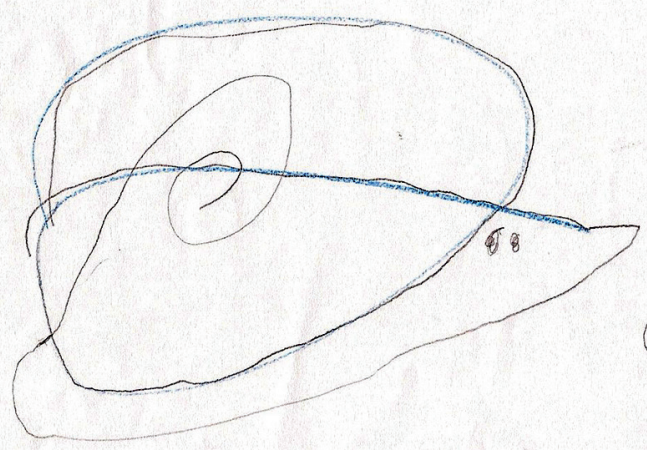

Calacol

(1)

Os desenhos do rabisco não puderam ser realizados na técnica correta, pois Goro começou e terminou os desenhos. O primeiro desenho foi um caracol que parece mostrar o seu estado emocional, regredido na chegada ao Brasil, fragilizado e rastejante como o caracol, tendo que se mostrar pela metade, como se tivesse que se esconder em sua capa protetora.

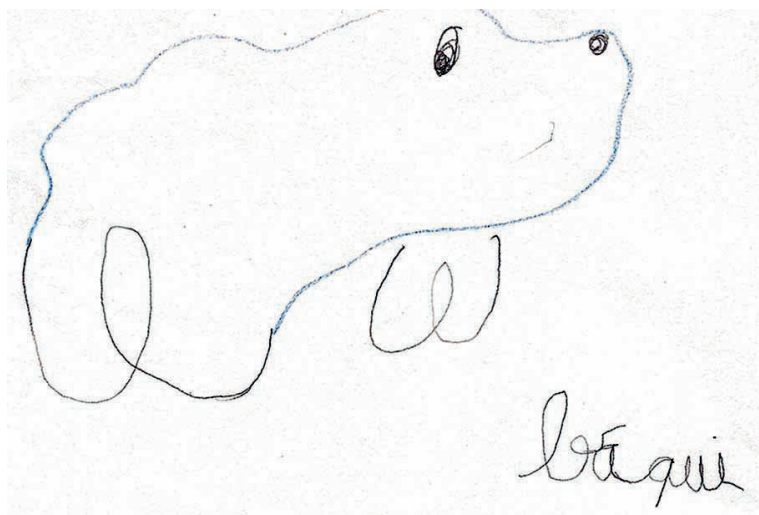

(2) 
O segundo desenho é de um cachorro que denominou "baqui". Nesse desenho, há ausência das orelhas e da boca.

\section{Desenho dos borrões de tintas}

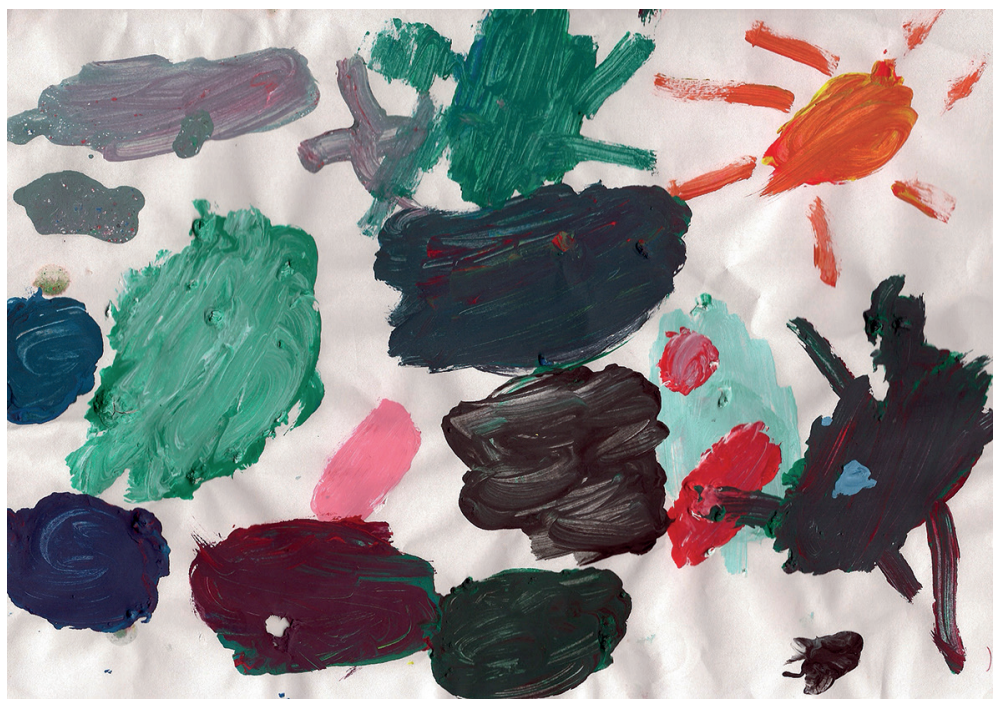

A criança Goro pega o jogo de pintura e vai misturando as tintas nos vidros e colocando-as no papel sulfite. Disse-nos que nunca havia feito essa mistura. Junto com a criança, em outra folha, vamos misturando as tintas. Parece-nos que a criança está conseguindo se misturar conosco. É uma nova descoberta de Goro. Algumas cores são verde-escuras, porém outras são pretas, e vermelhas com o laranja do sol. Podemos conjecturar que se trata da mistura do sol brasileiro (com a cor amarela) com o sol japonês (de cor vermelha), resultando num sol alaranjado. O sol da integração Brasil e Japão, no meio de muitas dores e lutos. 


\section{Considerações finAIS}

O retorno do imigrante ao país de origem significa muito mais do que voltar ao lugar que parecia ser familiar. A volta, portanto, não é tão simples como imaginamos ser. Os dekasseguis dizem sentir o problema de retorno à sua terra natal; como mencionam Assis e Campos (2009), "voltar é muito mais difícil que partir". O retorno ao país de origem traz muitos "estranhamentos", dificuldades de adaptação ou readaptação ao que era familiar e que agora demonstra um aspecto "estranho", principalmente de lembranças, ou seja, referências anteriores que os imigrantes tinham vivas em sua mente e que já não condizem com a nova realidade. O tempo é outro, faz parte de um passado que não existe no tempo presente e, além disso, o espaço geográfico modificou-se com o tempo, a paisagem não é mais aquela do passado, e, ainda com tudo isso, a família ou parentes que ficaram no Brasil se tornam "líquidos". Não conseguem se encontrar mais nos mesmos espaços e tempos passados, que, pelo menos, serviriam de conforto e amparo emocional. Sentem-se desamparados ao não encontrar mais a vida passada.

Conforme Grinberg e Grinberg (1984), ao chegar num mundo desconhecido, o imigrante pode encontrar muitas dificuldades internas de se integrar ao meio, por entrar em contato com objetos que lhe soam estranhos, tais como o idioma, os costumes e tantos outros 
aspectos que compõem o lugar. Surge o temor de não conseguir se comunicar com os outros e consigo mesmo.

Morar em outras terras é enfrentar o novo e o desconhecido. Ademais, é construir outra "subjetividade", "formas diferentes de pensar, sentir, perceber e falar, exige transformações pessoais profundas que beiram a uma despersonalização ou a um desmanche da identidade pessoal, difícil de ser suportada" (Justo, 2008, p.100).

Para essas crianças, filhas de dekasseguis, "partir" para o Brasil talvez não estivesse em seus projetos. Diante dessa nova realidade migratória, elas têm vivenciado muitos sofrimentos emocionais.

Essas crianças tiveram que fazer mais de um nascimento nessas idas e vindas ao Japão e ao Brasil. Qual seria o refúgio dessas crianças no Brasil, já que Eiko nasceu no Japão e tem algumas recordações remotas do Brasil? Apesar de as crianças Letícia e Goro terem nascido no Brasil e terem ido para o Japão em tenra idade, praticamente não trazem lembranças de suas vivências anteriores em terras brasileiras.

Nessas andanças migratórias entre Japão e Brasil, pais e filhos fazem vários nascimentos em família. Como é o retorno ou a volta dos dekasseguis em família para o Brasil? As dificuldades de adaptação ou readaptação geram desamparo emocional? O desconhecimento da língua portuguesa nessas crianças imigrantes leva ao desamparo emocional?

A vida por si só já pode ser considerada uma imigração, logo após o nascimento do indivíduo. $\mathrm{O}$ indivíduo, quando nasce, se desloca de uma condição de certo conforto gestacional para uma nova condição de vida, ou seja, se depara com um mundo desconhecido, vivendo ansiedades persecutórias, depressivas e confusionais.

Freud (1925-1926/1996) esclarece que a ansiedade é algo que se sente - um estado afetivo, portanto. A ansiedade é resultado de um aumento de excitação que, por um lado, produz o caráter de desprazer e, por outro, encontra seu alívio por meio dos atos de descarga.

Para Rank (apud Freud, 1925-1926/1996, p.147), “o processo de nascimento é a primeira situação de perigo, e a convulsão econômica que ele produz torna-se o protótipo da reação de ansiedade". Conforme Freud (1920-1922/1996), a ansiedade é um estado 
particular de esperar o perigo ou preparar-se para ele, ainda que possa ser desconhecido.

Esse novo nascimento desses imigrantes na terra brasileira seria feito em família, uma vez que os pais estariam retornando com seus filhos. Portanto, eles não estariam mais sozinhos.

Para Grinberg e Grinberg (1984, p.138), a família é uma “capa protetora" para a criança. No entanto, os autores relatam que esses pais se encontram desestabilizados emocionalmente com a migração e também precisam de um continente, pois se sentem desamparados.

Na verdade, a dificuldade já começa lá no Japão. Você vai sair de lá e medo de crianças, escola. O ano letivo lá não casa com o ano letivo daqui. Então, esse é um problema muito grande nessa questão.

Conforme a citação anterior, relatada pelo senhor Ito, a possibilidade de se reencontrar com a terra brasileira gera preocupações e medos antes mesmo da partida do Japão rumo ao Brasil. Enfatizamos que as suas preocupações de retorno ao Brasil estavam ligadas às crianças e à futura vida escolar.

Diante da fragilidade emocional dos pais imigrantes caracterizada por dois momentos de experiência, da "partida" e da "chegada", podemos pensar até que ponto esses pais conseguiram ser a "capa protetora" dos seus filhos, já que eles também estariam vivendo uma experiência de desamparo emocional.

Além das preocupações com as filhas, os pais de Eiko e Letícia também viviam momentos de muitas incertezas com relação ao futuro emprego e ao sustento da família no Brasil.

Lógico, na verdade o retorno para o Brasil você lança do mesmo jeito. Quer dizer, a diferença básica na verdade você não consegue mais ver, prever ofuturo, daquela maneira que a gente se previa. [...] Atualmente monta uma empresa e a gente não sabe bem o dia de amanhã. Até pelo menos você conseguir formar e engajar a empresa fica complicado mesmo. O momento de incerteza. 
O senhor M. Hossokawa, citado por Asari e Tomita (2000), mostra que os dekasseguis, ao retornarem para o Brasil, se deparam com a falta de emprego e uma formação profissional.

Os pais se sentem castrados em terras nipônicas, ou seja, perdem a potência salarial que lhes garantiria a continuidade de morada no Japão. Eles perdem o objeto bom internalizado e idealizado. Portanto, esses pais vivem muitas perdas, inclusive a perda da segurança financeira que haviam adquirido e que lhes permitia lidar com a lógica e a previsão em terras japonesas. $\mathrm{Na}$ atual situação, esses pais se viram desamparados na terra dos seus avós.

Sasaki (2004) menciona que há relatos de trabalhadores dekasseguis sobre as muitas dificuldades para retornarem ao Brasil, entre as quais a falta de condições financeiras e os baixos salários brasileiros comparados àqueles pagos no Japão.

Ao perceber que tomou sozinho a decisão de retornar para o Brasil, não dando opção de escolha para as suas filhas, o senhor Ito experiencia o sentimento de culpa, por separar as filhas do mundo japonês. Podemos pensar aqui em um "duplo sentimento de culpa", pelo "medo em dobro": por sua tomada de decisão de retorno ao Brasil e por perceber o sofrimento das filhas. Ou seja, o pai se responsabiliza por todos os transtornos ocasionados pela migração.

O senhor Ito assume uma posição tipicamente depressiva ao constatar as dificuldades de adaptação e o sofrimento emocional de suas filhas, depois de seis meses morando no Brasil. Trata-se de uma situação diferente do seu estado emocional no Japão e da chegada ao Brasil, quando lidava com ansiedades persecutórias e confusionais por causa da real situação econômica japonesa que influenciou e afetou os planos da vida familiar - ou seja, pensar na volta para o Brasil era, ao mesmo tempo, pensar na "saída" e na "solução" do problema, mesmo que fosse momentâneo, como uma pulsão de vida para autopreservação da espécie. O senhor Ito age com onipotência sobre a decisão de retorno ao Brasil, como se fosse um tripulante de um navio vivendo um naufrágio e que luta pela sua sobrevivência e de sua família.

O imigrante pode ser considerado um sobrevivente por natureza, em razão de tantas intempéries emocionais que percorre 
durante a sua vida migratória. Ele demonstra a enorme capacidade de resiliência e a plasticidade do ser humano para viver em condições adversas.

Para a senhora Haru, os abalos sísmicos e os problemas com as radiações das usinas nucleares japonesas despertaram medos e inseguranças. A família passou a viver no Japão sentimentos primitivos de ansiedade, como o medo de aniquilamento. A fantasia de que a terra japonesa agora é um objeto mau e que representa ameaça de morte a seus filhos imigrantes passa a ser constante na vida deles. O retorno para o Brasil se configura, subjetivamente, como um mecanismo de defesa, de fuga para a sobrevivência do ego, deixando para trás um ambiente inseguro e refugiando-se em terras brasileiras.

Eu falei primeiro que a gente estava voltando. Uma, pela condição do Japão, né? Já estava apresentando risco. Nós já presenciamos o terremoto, lá em Nagano, apesar de ser um estado longe, nós sentimos. Abalou. Até que as crianças ficavam meio assim, toda vez que ficava balançando as coisas, eles ficavam com medo. Até tinha deixado uma bolsa de emergência junto, perto, quando acontecesse alguma coisa pra gente poder correr, né?

Podemos dizer que os perigos vividos pela senhora Haru, no caso, os abalos sísmicos japoneses, eram perigos reais e, portanto, conhecidos. A ansiedade sinal ou de alarme corresponde a um perigo já vivido, de uma experiência anterior, e que se repete de forma atenuada, como um aviso ou sinal de alarme. Portanto, é uma forma que o ego encontrou para se preparar e proteger de um perigo interno ou externo, evitando a ansiedade automática, que é a ocorrência de uma situação traumática e cuja essência é uma experiência de desamparo por parte do ego, com o qual não pode lidar (Freud, 1932-1936/1996).

Os pais dekasseguis e seus filhos vivem momentos difíceis nas terras dos seus antepassados. "Partir" ou "ficar" - é assim que os pais se viam naquelas semanas precedentes à viagem de retorno ao Brasil, pois a a volta não seria tão fácil para essas famílias que já 
estavam morando havia alguns anos no Japão. Teriam que deixar tudo para trás, não somente o Japão, mas a história de suas vidas.

Para Grinberg e Grinberg (1984), o trabalhador estrangeiro tem um tempo determinado para retornar ao país de origem e é visto pelos locais mais como um convidado desejado do que um intruso, ao passo que os "imigrantes", mesmo com autorização para ingresso e trabalho no país receptor, como é o caso dos dekasseguis, são percebidos como intrusos, perigosos, não confiáveis e tantas outras peças negativas. Formam uma categoria social específica, decorrente do lugar em que são colocados, pelas funções que exercem e catalisam nos planos econômico, político, cultural e psicossocial. Portanto, o "estrangeiro" tem um prazo determinado para deixar o país, ou seja, a sua estadia no exterior tem um "fim"; já o "imigrante" é quem decide a sua condição de "ficar" ou "partir" do país receptor.

As famílias, ao chegarem ao Brasil, normalmente são acolhidas pelos parentes que as esperam no aeroporto. É de extrema importância esse acolhimento familiar para o imigrante que retorna de outro país. Na partida ou na chegada, os parentes que ficaram no Brasil, a princípio, servem como uma âncora protetora, ou seja, um continente para amparar os que vão embora e os recém-chegados no que diz respeito aos sentimentos de estranhamento e de choque cultural no país de chegada.

A idade da criança imigrante é relevante no processo migratório, conforme destacam Grinberg e Grinberg (1984), uma vez que a imigração é experienciada de forma distinta para cada fase; a adolescência, por si só, já é uma fase migratória, pois, segundo esses autores, o adolescente encontra-se em transição para a vida adulta.

O senhor Ito também aponta a idade da criança imigrante como fator relevante no processo de adaptação/readaptação no país. Quando se deslocam bebês ou crianças menores para outros lugares ou outros países, estes parecem assimilar mais facilmente a nova vida. Além do mais, o senhor Ito enfatiza que a dificuldade maior foi no retorno para o Brasil. 
Com certeza! O processo de adaptação no Japão e no Brasil devido à idade. Acho que o processo de adaptação foi mais acentuado, a dificuldade maior foi aqui no Brasil do que no Japão devido à idade. Ela foi com 3 anos e retornou já estava com 10. Então, essa questão de como ela foi muito pequena para lá, a adaptação ficou até mais fácil e a aceitação foi bem melhor do que agora.

A idade da criança imigrante deve ser considerada nesse processo de deslocamento. Eiko havia terminado o terceiro ano na escola japonesa e iniciado o quarto ano no Japão. Ela chega ao Brasil com 9 anos e 9 meses de idade e ingressa na escola alfabetizada na escrita japonesa. A língua portuguesa lhe soa estranha e é desconhecida por ela.

Ao nascer, o indivíduo faz sua própria imigração, e Grinberg e Grinberg (1984) consideram a história que cada um percorre durante a sua vida. Entretanto, o indivíduo é um imigrante de seu mundo ao fazer a sua própria história. Apesar de sua pouca idade como (e)imigrante, Eiko está vivendo outra fase imigratória em sua vida. Atualmente, está com 13 anos de idade - transitando da infância para a vida adulta -, encontra-se na adolescência, crescendo para atingir a maturidade. Entre dois mundos, a infância e a puberdade, no meio das turbulências próprias da adolescência, aparecem turbilhões de emoções e não se sabe qual é o caminho a ser enfrentado nessa longa jornada de transição.

Além do fator idade, temos que levar em consideração o grau de escolaridade dessas crianças no ato da migração. Eiko se alfabetizou na língua japonesa e concluiu no Japão a $3^{\mathrm{a}}$ série, iniciando a $4^{\mathrm{a}}$ do ensino fundamental, ao passo que Letícia, aos 6 anos, cursou a metade da $1^{\text {a }}$ série no Japão e retornou aos 7 anos de idade para o Brasil; e o menino Goro chegou ao Brasil com 9 anos de idade, tendo cursado no Japão até a $2^{\mathrm{a}}$ série do ensino fundamental.

A questão do tempo de permanência da criança imigrante na escola japonesa também pode ser considerada um impasse na chegada à escola no Brasil e gerador de desamparo emocional?

Será que o fator idade contribui para intensificar o desamparo emocional dessas crianças (e)imigrantes? 
Pudemos constatar na pesquisa que são três crianças dentro da própria família que fazem caminhos escolares distintos por causa da idade, do grau de escolaridade e da escolha de seus pais. Eiko e Goro chegaram ao Brasil com quase a mesma idade. Goro, após chegar ao Brasil, não foi matriculado imediatamente na escola, mas, sim, numa escola de idiomas, o que lhe permitiu ter contato com a língua portuguesa e se preparar para a alfabetização. Eiko e Letícia, por sua vez, foram matriculadas na escola de ensino fundamental sem esse preparo anterior e conhecimento do idioma.

O senhor Ito e a senhora Natsu, pais de Eiko e Letícia, acreditavam, na época, que contratar uma professora de língua portuguesa e estudar junto com as filhas possibilitaria, de forma rápida, a obtenção de excelentes resultados. Pressionadas pelos seus pais, Eiko e Letícia tinham que aprender a todo custo a nova língua; portanto, a família se depara com uma real necessidade escolar.

Esse momento de vida para essas crianças representa um novo e duro nascimento. As crianças filhas de dekasseguis perderam não somente a língua japonesa, mas também toda uma representação cultural vinculada a uma maternagem oriental vivida na relação com as professoras das escolas japonesas e com a própria mãe que, ao tornar-se imigrante, muda sua forma de se relacionar com os filhos.

Os pais de Eiko e Letícia, ao proibirem o uso da língua japonesa e de tudo que se referenciasse ao Japão dentro de casa, quebraram a construção da comunicação subjetiva e do pensamento abstrato familiar. O sentimento dessas crianças é de se sentirem "estrangeiras" dentro do próprio lar.

PESQUiSADORA: Vocês conversavam em português dentro de casa com elas no Japão? SRA. HARU: Só japonês.

Ao chegaram ao Brasil, Eiko e Letícia perderam os pais bons e se depararam com os pais onipotentes, castradores, ou seja, pais ruins. Os métodos de aprendizagem dentro de casa com os pais são considerados drásticos pelo próprio senhor Ito, como mostra no relato seguinte: 
Mas os métodos de adaptação foram um pouco drásticos. Tentamos, inicialmente, um ponto inicial: forçar o português de tudo qual jeito. Foi forte, foi brusco, de tudo que ela tinha aprendido na cultura dela, tudo que ela levava e vivia simplesmente jogar [...]. Inicialmente foi feito um tipo de uma coisa, vamos falar assim: de cortar a utilização do poder, de cortar, por exemplo, a língua japonesa, cortar desenhos, cortar, tentar tirar um pouco. Isso foi muito drástico, foi uma revolta muito grande e não estava dando. [...] [Foi] logo no início. Na verdade ela tinha excesso de dados, tinha aula particular, a gente ficava todos os dias até sete e oito horas da noite estudando. Passava o dia inteiro estudando e contando um para o outro: A língua portuguesa, não sei! Então, cortamos todas as regalias. Acaba indo, naturalmente, ela acaba indo para a língua japonesa. Forçamos bastante nesse quesito, mas não houve resultado positivo. Então, era muito, não aceitava. Chorava muito. Então, para aceitar estava muito difícil.

O desamparo emocional já é sentido dentro da própria família. Contradizendo Grinberg e Grinberg (1984, p.138), que ressaltam que a família é considerada uma "capa protetora", no exato momento da migração esses pais estavam desajustados emocionalmente, viviam uma situação de desamparo e precisavam de ajuda alheia. No ato da migração, os pais e as crianças não tiveram a quem recorrer, ou seja, a quem gritar um pedido de socorro. As crianças se viram sozinhas, sem um continente que as pudesse acolher emocionalmente.

Podemos pensar na noção freudiana de desamparo, apresentada pela primeira vez em 1895 no "Projeto para uma psicologia científica" (Freud, 1886-1889/1996), no contexto sobre "a experiência de satisfação", que expressava que :

O organismo humano é, a princípio, incapaz de promover essa ação específica. Ela se efetua por ajuda alheia, quando a atenção de uma pessoa experiente é voltada para um estado infantil por descarga através da via de alteração. Essa via de descarga adquire, assim, a importantíssima função secundária de comunicação, e o desamparo 
inicial dos seres humanos é a fonte primordial de todos os motivos morais [Cf. p.420]. (Freud, 1886-1889/1996, p.370.)

Paradoxalmente, o senhor Ito e a senhora Natsu estão em torno das crianças, porém ausentes de olhares e escutas emocionais para com as suas filhas. Esses pais não puderam dar às filhas o amparo emocional de que elas tanto necessitavam na época. Não havia uma linguagem familiar que pudesse interpretar e ligar os dois mundos: dos pais e das crianças, que se tornaram quase "incomunicáveis".

De acordo com Winnicott (1896-1971/2005, p.26-7), cujas teorias contribuem para a compreensão da capacidade materna na relação com o bebê, "O holding tem muita relação com a capacidade da mãe de identificar-se com seu bebê. Um holding satisfatório é uma porção básica de cuidado [...]”. Portanto, logo na chegada ao Brasil, as filhas Eiko e Letícia perderam o continente da linguagem familiar e se depararam com a falta da relação materna satisfatória, que proporcionaria às crianças uma maior capacidade de desenvolvimento emocional.

Os sonhos de Letícia revelam imagens de ansiedades persecutórias de uma fuga familiar pela sobrevivência. De acordo com um de seus sonhos, a imagem do monstro que a perseguia e que trazia medo se assemelhava à imagem do ser humano. Associa uma família que está perdida em algum lugar e, ao mudar a paisagem do sonho para o ambiente familiar que denomina de "casa", sente-se internamente amparada; porém, a porta que se abre nessa nova história nos remete ao contato de Letícia com o novo ambiente misturado com sentimentos de vida e morte. $\mathrm{O}$ frio e a ameaça de congelamento sentidos pela criança no sonho nos mostram que o perigo sentido por ela está no mundo externo. De acordo com Freud (1925-1926/1996), a ansiedade é algo que se sente, sendo, portanto, um estado afetivo. Esse sonho é uma manifestação do sofrimento emocional de desamparo de Letícia, e o "tremer" indica o quanto a família estava totalmente desamparada emocionalmente e precisava ser coberta por uma continência humana. 
Às vezes, eu sonho quando a minha família está em algum lugar, fugindo de alguma coisa e troca. Acho que estava fugindo de um monstro que a gente não estava conseguindo pegar e quase quando pega o monstro e vai para o outro sonho. PESQUISADORA: Como que é esse monstro? LETÍCIA: Era grande, maior que a gente, barrigudo, barba, cabelos, mãos, pernas e usava roupa. Parecia com o ser humano mesmo. Ele poderia dominar o mundo, e a gente não queria que ele dominasse, por isso que a gente quase o pegou e mudou para outro sonho. O outro sonho mudou para a nossa casa. Estava vivendo muito feliz. A porta e a janela estavam fechadas, a gente tremia de frio, a gente era muito feliz. Quando abriu a janela e a porta, nós morremos de frio e acabou o sonho. PESQUiSADORA: Como é morrer de frio? LETícIA: A gente estava tremendo, que quase a gente congelou de frio.

A experiência de mudança de lugar é tão forte e marcante, na saga migratória dos dekasseguis, que até os sonhos utilizam a mudança como principal metáfora. Letícia destaca, nas narrativas de seus sonhos, imagens de mudança e também as utiliza (de um sonho a outro) como estratégia de enfrentamento de ansiedades emergentes.

\section{Língua}

No Japão, pais e filhos falavam a mesma língua, a japonesa. No Brasil, passam a falar uma língua diferente - a língua portuguesa -, ou seja, a língua "estrangeira" para as crianças.

No livro Língua(gem) e identidade, no texto "Sendo índio em português", Tereza Machado Maher (1998, p.120) mostra o desejo dos professores índios de aprender a língua tradicional do seu povo para ensiná-la aos alunos.

Esta vontade [de aprender Shawãdawa] vem porque além de ser a nossa língua de minha comunidade, ela é nossa língua própria mesmo [...] Eu falo, eu estou falando aqui em português: a cara, a língua, a boca tudo é minha, agora a fala não é minha porque é 
emprestada [...] [após uma pequena pausa, sorrindo] Num é éé, né? vai e vem $[\ldots]$ é, e num é.

Podemos perceber, nesse discurso, que o professor índio, ao mencionar a língua portuguesa, diz que a sua fala está sendo "emprestada”, desconsiderando a língua portuguesa como língua nativa.

Qual é a língua nativa de Eiko, que nasceu no Japão e foi educada na língua japonesa? E quanto à língua de Letícia, que nasceu no Brasil e migrou para o Japão antes de completar 1 ano de idade? Ela teve a mesma formação educacional de sua irmã Eiko? E o menino Goro, brasileiro nato que partiu para o Japão com quase 2 anos de idade? Sua educação teve o mesmo desenvolvimento de suas primas? Qual será a língua emprestada dessas crianças?

Esse é outro entrave com o qual nos deparamos: a barreira da língua portuguesa. Durante toda a sua permanência no Japão, essas três crianças estudaram somente em escolas japonesas. A comunicação dos pais e filhos no Japão ocorria na língua japonesa. Portanto, no Brasil, os pais fazem o processo inverso, usam a língua "estrangeira", ou seja, a língua portuguesa, uma língua que não era da compreensão das crianças, para se comunicar em família. Esse rompimento com a língua japonesa foi imposto, pelos pais de Eiko e Letícia de maneira drástica.

EIKO: Hum... Com a palavra em português está um pouquinho difícil. E também não conseguindo ir junto com os meus colegas, eu atrasei um pouquinho.

PESQUiSADORA: Por que você acha que não consegue aprender muito? EIKO: Hum. Porque é me acostumei no Japão e eu nunca usei o português no Japão. E acostumei falar japonês e não estou conseguindo aprender muito o português e é difícil.

EIKO: Eu com minha irmãzinha falava japonês. Às vezes ensinava falar português, mas não conseguia aprender escrever, mas minha mãe e meu pai conversava em português e eu não entendia. 
Essas crianças, além de lidarem com tantas perdas - a vida em terras japonesas, os vínculos que lá construíram e deixaram para trás -, também perderam o convívio com a cultura do país que elas consideravam familiar, além da única língua que até então conheciam e que fazia parte do seu mundo.

O desamparo emocional desencadeado pela perda da língua japonesa, que tem toda uma representação simbólica e cultural, traz à tona o trauma do nascimento. Eiko se vê sozinha e desamparada, não podendo contar com a ajuda dos próprios pais.

São muitas as barreiras da língua enfrentadas por essas crianças no Brasil: transcedem outros territórios, trazem dificuldades e afetam a comunicação com os próprios parentes que as acolheram no Brasil, além de prejudicá-las no ambiente escolar. Essas dificuldades de compreensão da língua oral são sentidas pelas duas partes: por aqueles que estão ao redor dessas crianças e pelas próprias crianças imigrantes, que desconhecem a representação da linguagem cultural brasileira. Portanto, ambos os lados desconhecem o mundo do outro.

Pesquisadora: O Japão e o Brasil ficam misturados? Letícia: Não! Não é que o Japão é tão fácil. Eu fui para o Japão e ficou fácil para mim. Estudei desde criança. Quando vim para o Brasil ficou difícil para mim, porque não acostumava, não sabia ler. PESQUISADORA: Você assistia aos filmes brasileiros no Japão? LeTícIA: Não. Porque não sabia o português.

PESQUisadora: Quando chegou ao Brasil, qual era a sua dificuldade? Goro: De falar. É ruim um pouquinho, complicado para mim. Difícil de aprender. PESQUISADORA: Como fazia para falar? GORO: Falar com cuidado, pra não errar. PESQUISADORA: Quando chegou ao Brasil, falava português ou japonês? GORO: Português. Alguns queriam que falasse japonês. Alguns meninos, né. Eu falava o japonês e português. Falava um pouquinho errado o português. PESQUISADORA: Parece-me que hoje você tem falado melhor o português? GORO: Senão, as pessoas não entendem. PESQUISADORA: Parece-me que também tem conseguido entender melhor o português. GORO: O português. 
As paisagens e a língua dos sonhos dessas crianças estão no mundo oriental, conhecido e dominante em seus pensamentos e sentimentos.

GORO [tradução da senhora Haru]: Falo a língua japonesa no sonho. Nunca sonhei com nada daqui. SRA. HARU: No Japão, Goro dormindo chorava muito à noite. Aqui no Brasil, ele sempre está mais alegre.

EIKO: Com mais paisagens do Japão, porque lembro muito tempo, fica na cabeça.

Todo japonês [ri]. Quando sonho no Brasil é japonês, não sei o porquê. Nunca sonhei português, nem inglês e língua diferente.

O esquecimento da língua japonesa traria muitas perdas para Eiko. A língua japonesa, além de representar a mãe japonesa, o objeto bom internalizado, também é uma forma de estimular uma integração com as outras crianças descendentes de japoneses que moram no Brasil e que estudam a mesma língua, a quem Eiko conhece. Portanto, manter a língua viva para Eiko é manter o desejo vivo do sentimento de retorno e a possibilidade de se encontrar novamente com a mãe oriental.

Pesquisadora: Por que tem que estudar japonês? EIKO: Para não esquecer e não perder para a minha amiga.

A competição instigada pelos próprios descendentes de japoneses nesses testes de proficiência da língua japonesa gera um sentimento de disputa entre eles, como se fosse uma corrida para ver quem conhecesse melhor a mãe japonesa. Esse desejo veemente pelo conhecimento do mundo japonês buscado pelas crianças filhas de dekasseguis representa o filho que, mesmo de longe, está vinculado às lembranças, às experiências, à linguagem mecânica e cultural do país. 


\section{Retorno para o Japão}

Segundo Higa (2006), o "voltar atrás" não é no sentido da cura, mas, sim, no sentido da elaboração, ou seja, o retorno ao passado é vivenciado como meio de libertação.

Lembramo-nos de Eliade (1972), segundo o qual, na tentativa de abolir o tempo, de dominá-lo diante do tormento de passagem e da finitude humana, o homem utiliza da técnica de "voltar atrás" ou de "retornar às origens", ou seja, "para curar-se da obra do tempo é preciso 'voltar atrás' e chegar ao princípio do mundo" (Higa, 2006, p.34).

Justo (2008) corrobora que o desejo de retornar ao país de origem se mantém vivo e forte no imigrante. Esse retorno não difere de outras experiências de voltar ao lugar de origem, para o lugar que se conhece, marcado pela história de sua infância que representa em suas memórias o passado.

Segundo Justo (2008, p.110), partir e retornar estão intrinsecamente relacionados. $\mathrm{O}$ autor cita o exemplo do viajante que, na despedida, já manifesta o desejo de voltar. Portanto, despedir-se dizendo "até a volta", "volte sempre" ou "volte logo" faz parte do vocabulário do cotidiano alimentado pela ânsia do retorno.

Fazer muitos amigos. Fazer compras nas lojas. Fazer uma casa. PESQUISADORA: Hoje você sente vontade de voltar para o Japão? LETíCIA: Tenho como antes. Pesquisadora: Aqui no Brasil, como se sente? LETícIA: O Brasil é o lugar que nasci. Agora estou de volta. De primeiro achava que era um lugar chato. Agora, estou gostando.

As filhas de dekasseguis são crianças que têm a experiência de viver em duas culturas. Notamos em Eiko o sentimento de ambivalência, o de ficar no Brasil, mas também o de construir o futuro próximo no Japão. 
EIKO: Queé "intenção"? PESQUISADORA: Vontade. Qual a sua vontade? EIKO: Quero ir no Japão fazer outras coisas, fazer minha faculdade, mas também quero ficar no Brasil e fazer o [Nome do comércio dos pais], meu pai e mãe vai [Nome do comércio dos pais], porque fica velho no [Nome do comércio dos pais], então também quero ficar no Brasil e no Japão.

O desejo de retorno não é somente encontrado nos adultos; as crianças também mostram o desejo de voltar à terra japonesa.

PeSquisadora: Você prefere o Japão ou o Brasil? Letícia: Os dois. Acho que é legal. PESQUISADORA: Você sente muita falta do Japão? Letícia: É. Pesquisadora: Você está sempre pensando no Japão? Letícia: Sempre. Acordo e durmo. No Japão tinha coisas legais. Tinha neve. Coisas que eu interessava. PESQUiSAdora: O que você gosta no Brasil? LetícIA: Gosto dos meus amigos, que são legais. Coisas para aprender. Acho que gosto mais ou menos. PESQUISADORA: Está falando que do Brasil gosta mais ou menos. E do Japão? LetícIA: Eu gosto muito! PESQUISADORA: Você pretende algum dia voltar para o Japão? LETícIA: Quando crescer, eu quero tentar ir. Morar lá. Fazer faculdade. PESQUiSADORA: Qual a faculdade que gostaria de fazer? LetícIA: Não sei ainda. PESQUISADORA: Você sonha com o Japão no seu futuro. Letícia: Sim.

Pensar em voltar é a forma que o ego encontrou para não se desvincular da terra-mãe. A distância da terra-mãe gera conflito com a realidade (Hashimoto, 1995).

PESQUISADORA: Você quer saber alguma coisa do Japão? Letícia: O Japão está tendo terremoto? PESQUISADORA: O Japão tem terremotos. É um país que vive com terremotos. LETÍCIA: Quando crescer quero ir ao Japão. Fazer doações de doces e moedas. Fazer uma fábrica de docinhos para crianças normais também. Eu quero tentar qualquer coisa. No Brasil o emprego é difícil também. Eu quero ser cantora também. Eu só sei cantar música do Japão. 
PESQUiSAdora: O que sente e pensa quando vê as fotos do Japão? LETíCIA: Às vezes penso que quero voltar mais uma vez para o Japão. Pesquisadora: O que iria fazer no Japão? Letícia: Brincar mais. Fazer as coisas direito. Eu queria fazer e não conseguir fazer. PESQUISADORA: Você fala que tem vontade de voltar para o Japão? LETÍCIA: Muito! PESQUISADORA: Quais são essas coisas que gostaria de fazer no Japão? LETíCIA: Ir para a escola e estudar direito.

A fantasia de que o Brasil era um lugar deserto, inabitável, surge no relato de Letícia quando diz ter que deixar o oásis japonês e se deslocar para um lugar sem recursos, em busca de sobrevivência. A criança faz várias comparações entre o Brasil e o Japão. Critica a tecnologia brasileira, considerando-a de baixa qualidade, o mau comportamento dos brasileiros em relação aos professores e a falta de consciência em jogar lixo na rua. Essas diferenças são nitidamente observadas pelas crianças.

Pesquisadora: Você se sente feliz no Brasil? Letícia: Às vezes sinto feliz. Às vezes acho chato ir para escola. Eu conheci amigos. A escola é boa. Pensei que o Brasil era um deserto. Monte de areia e muito quente. Pesquisadora: No Brasil não tinha gente morando? Letícia: Não. Pesquisadora: Então, vocês seriam os primeiros habitantes.

Foi na desvalorização do país presente - no caso, o Brasil -, no sentimento de rejeição, que a criança encontrou uma forma de negar a nova realidade vivida por ela. Assim, portanto, consegue preservar o país ausente. "O Brasil cheira muito fedido. Não tem esgoto. Cheira xixi e cocô."

Pesquisadora: Por que achava o Brasil um lugar chato? Letícia: Não era igual o Japão. No Japão é muito liso. No Brasil tem quebra-molas. E por isso, eu não gosto. PESQUISADORA: No Brasil tem obstáculos que você não gosta. Qual é o seu maior obstáculo? LETícIA: No Japão a comida e a escola são gostosas. No Brasil a comida é mais ou menos. As lojas não são bonitas. Eles vendem coisas que não prestam. 
Para a criança imigrante filha de dekasseguis que chega ao Brasil, parece ocorrer o processo inverso: ela não desvaloriza o país ausente, no caso o Japão. Ela o faz com o país presente, mantendo os aspectos positivos do país japonês ausente.

De acordo com Hashimoto (1995, p.93):

A desvalorização do ausente, que significa a negação dos aspectos positivos da terra natal, enquanto busca do seu próprio caminho, é dificultada pela rejeição da terra presente. Apesar da única tentativa de solução do impasse ser a desvalorização, mesmo que agressiva, torna-se difícil a passagem para a idealização do ausente. É a vivência da perda, através do desgaste da imagem ideal, o mecanismo usado para possibilitar o engrandecimento desse ideal perdido, num processo de reparação e de projeção para o passado.

Permanecem, nessas crianças, a idealização da terra ausente, a japonesa, e a negação dos aspectos bons da terra brasileira. Isso dificulta a elaboração do luto. As crianças passam a negar a nova realidade psíquica, usando de defesas maníacas, como a onipotência, o desprezo e o triunfo sobre os aspectos negativos do mundo brasileiro.

Depois de algum tempo de separação da terra japonesa, Eiko e Letícia ainda não conseguiram se desligar da terra ausente.

Na separação, a pessoa deve desligar-se da imagem idealizada do ausente e procurar substituí-la por outros ideais. Além disso, precisa continuar desenvolvendo as suas atividades normais para possibilitar a continuidade do ego. A separação consiste, portanto, na tentativa de vencer os sentimentos de ambivalência entre a lembrança idealizada e o frágil compromisso com o objeto atual. A forma mais adequada de solucionar tais conflitos é lançar mão de defesas. São esses mecanismos que vão possibilitar o desenvolvimento e adaptação à situação nova [...] e controlar essa ambivalência. (Hashimoto, 1995, p.96) 
Hashimoto (1995) lembra, ainda, que o migrante, depois de algum tempo longe da terra natal, pode perceber a diferença entre o que é idealizado e que é real. Assim, essa desilusão faz o processo de luto se concretizar com o processo de diferenciação. $\mathrm{O}$ migrante passa a perceber a nova terra e começa a se separar da terra-mãe. Não entanto, tal separação não implica o esquecimento total, senão o ego sucumbiria.

\section{Ambientes escolares japonês e brasileiro}

As dificuldades encontradas por essas crianças são sentidas em ambos os ambientes escolares, ou seja, tanto na escola japonesa como na escola brasileira. O choque cultural e o sentimento de estranhamento ocorrem quando elas se deparam com a língua e o ensino escolar programado.

EIKO: O kanji era um pouco difícil de aprender, porque veio da China. Confundia com vários outros kanjis. $O$ adulto tem que aprender o kanji e dá para entender mais coisas e palavras. PESQUISADORA: Como se sentia no Japão? EIKO: Não tinha medo. Tinha que fazer a recuperação até tirar nota azul. Eu conseguia. Eu fiz duas vezes, estava difícil.

Não podemos deixar de considerar que esses pais dekasseguis descendentes de japoneses -, mesmo sabendo falar e tendo algum domínio da língua japonesa, não são japoneses nativos. Esses dekasseguis são imigrantes, foram para o Japão para trabalhar em serviços de baixa qualificação, se ausentando da vida cotidiana de seus filhos em razão do excesso de carga horária de trabalho e da exaustão física e emocional. Portanto, esses pais têm pouco tempo para ficar com os filhos, e geralmente esses poucos encontros acontecem nos finais de semana, tempo que dividem entre os filhos e suas compras em mercados. 
Essas crianças se sentem em "déficit" aqui e lá no Japão, tendo que correr atrás de um "tempo perdido". Apesar das dificuldades da escrita e da compreensão do kanji, Eiko conseguiu recuperar as suas notas nas avaliações. Entretanto, no Brasil a situação é muito mais complicada, porque a sua dificuldade não é tão simples. A adolescente Eiko corre atrás de um tempo que não existiu em sua vida.

EIKO: Quando estava no Japão entendia, mas não conseguia responder. Estava no infantil. Tinha 3 ou 4 anos. PESQUISADORA: Como fazia? EIKO: Respondia com a cabeça, mãos [gestos]. PESQUISADORA: Qual foi mais difícil, o Japão ou o Brasil? EIKO: Quando voltou para o Brasil foi mais difícil. Eu não entendi nada. [...] Só sabia algumas palavras em português. Não sabia as regras, os costumes. Ainda está sendo muito difícil. É mais fácil acostumar com os costumes, um ano. Estava muito tempo no Japão. (grifo nosso)

O tempo para se adaptar a outro país é necessário e deve ser considerado nesse processo; é como um bebê que vai introjetando esse novo meio durante o seu desenvolvimento biológico, psicológico e social. Diante de tudo isso, essas crianças imigrantes vivem num "tempo acelerado", porém atrasadas no tempo e no aprendizado escolar brasileiro, tendo que lidar constantemente com o sentimento de fracasso e impotência, que resultam em desânimo e preguiça.

PESQUISADORA: O que pretende fazer nas férias? EIKO: Nas férias, estudar um pouquinho de japonês, que está esquecendo, e brincar um pouquinho. PESQUiSAdORA: Parece-me que você tem medo de esquecer a língua japonesa. EIKO: Para mim o japonês é uma ponte que atravessa a língua portuguesa. Não quero quebrar. PESQUISADORA: Como que é essa ponte? EIKO: Para mim, não consigo falar inglês e nem entender, não dá certo. Falta a língua portuguesa e a japonesa. Para aprender a língua portuguesa, tem que usar a língua japonesa. Exemplo: uma palavra que não sabia, pergunto para a minha mãe e ela traduz. A minha mãe explica em japonês para entender mais fácil o português. PESQUISADORA: Você sente que precisa do japonês para entender a língua 
portuguesa. EIKO: É. PESQUISADORA: E quando não sabe a palavra na língua japonesa nem na portuguesa? EIKO: Se é palavra em japonês, se não entender, fico procurando no dicionário japonês. Em português não consigo. O dicionário explica difícil. Pra mim, não entende. PESQUISADORA: Então, você fica sem entender. EIKO: É.

No relato seguinte, Eiko mostra o sentimento de desamparo dentro da sala de aula. Não teve voz suficiente para falar e ser correspondida. Como Freud menciona no "Projeto para uma psicologia científica” (1886-1889/1996, p.370), “o organismo humano é, a princípio, incapaz de promover essa ação específica. Ela se efetua por ajuda alheia [...]”. Eiko não pode ser vista; faltou o olhar do adulto para que não caísse em desamparo emocional. Freud diz que a descarga por meio da via de alteração interna da criança promove a função secundária de comunicação entre a criança e o adulto. Entretanto, Eiko não consegue se comunicar e tampouco se livrar da sua angústia, ficando sozinha e desamparada emocionalmente na sala de aula.

EIKO: É legal, não usa muito o português e elas também "conversa" comigo, não fico vergonha e não fico quietinha. PESQUISADORA: Isso no Nikkei Clube? No Nikkei você conversa? EIKO: Hum. PESQUISADORA: Na escola que estuda você tem amigos? EIKO: Tenho pouquinho. Não consigo ficar muito amiga comum que eu fico no Nikkei. PESQUISADORA: No Nikkei já é diferente. Você sente que consegue ter mais amizades no Nikkei. EIKO: Uhum!

As duas mães integradas, a japonesa e a brasileira, seriam a relação satisfatória, ou seja, a relação com um objeto total, integrado, e não parcial e fragmentado. 


\section{Formação de vínculos}

A identificação dessas crianças migrantes com a cultura brasileira e com os colegas brasileiros não acontece de imediato. A formação de novos vínculos dessas crianças em terras brasileiras é prejudicada, pois a construção de uma nova amizade acaba levando mais tempo.

O desconhecimento da língua portuguesa afeta na formação de novos vínculos? O sentimento de vergonha dessas crianças acaba atrasando a formação de novas amizades?

Eiko, até o momento presente, não conseguiu fazer novas amizades. Ela já sabe se comunicar o suficiente para construir laços de amizade, mas vive isolada.

O isolamento é um mecanismo de defesa inconsciente que o imigrante utiliza como uma proteção e preservação do ambiente antigo.

As demais crianças - Letícia e o primo Goro - estão mais integradas ao novo meio. Dizem ter amigos, apesar de estarem ainda superando, diariamente, as dificuldades com a língua portuguesa.

\section{Sentimento de vergonha}

O sentimento de vergonha é sempre deflagrado quando há a necessidade de se expor diante de uma situação corriqueira. O sentimento de vergonha é sentido pelas crianças como medo de errar, que é uma vivência constante em sua vida, como se não pudessem lidar com as falhas e o fracasso, ou seja, com sua própria impotência. A vergonha e o medo de errar mostram o quanto a cultura japonesa está assimilada por essas crianças. A perfeição e a condenação parecem caminhar juntas nas tradições milenares do povo japonês.

EIKO: Tenho vergonha, ainda um pouco. Já li uma vez que a professora pediu. PESQUISADORA: Como foi? EIKO: Todo mundo ficou um pouco contente. PESQUISADORA: O que sentiu na hora em que estava lendo? EIKO: Senti que não posso errar. 
O sentimento de vergonha da criança está ligado ao "não saber" diante do desconhecido.

Pesquisadora: O que você estava fazendo? Letícia: Estava esperando a professora. Quando ela chegou, me apresentou. Eu tinha vergonha. PESQUISADORA: Por que você tinha vergonha? LeTícIA: Não sabia as coisas direito, não sabia as palavras. PESQUISADORA: Como era essa vergonha? LETícIA: Vergonha de falar. No Japão não tinha vergonha dos amigos da minha irmã.

O sentimento de vergonha não está presente só nos diálogos das crianças filhas de dekasseguis; também a mãe de Goro, a senhora Haru, diz sentir vergonha e medo de cometer alguma falha.

Pesquisadora: Você tem amigos? Goro: Todo mundo! PesquiSADORA: No intervalo como que é? Goro: Conversa pouco. Eu tenho vergonha. Vai rir de mim. PESQUISADORA: Por que pensa que as pessoas vão rir de você? GoRO: Penso assim.

SRA. HARU: Estar na frente de todo mundo e falar errado. Nossos termos são antigos. Eles usam muitos termos ingleses. Penso: "Será que falo? Ou não falo?". PeSQUiSADORA: Você fica na dúvida? SRA. HARU: Sim. Penso "Será que falo? E se falar errado?". Japonês é tudo sistemático. Às vezes você não se encaixa aí.

A senhora Haru nega que os japoneses possam sentir vergonha, como se isso fosse um sentimento gerado nos descendentes de japoneses brasileiros. Vemos aqui a idealização do povo japonês perfeito, sem sentimentos de inferioridade; os japoneses ficam com o sentimento bom, e os seus descendentes brasileiros, com a vivência do sentimento ruim.

PESQUiSAdORA: Quando não consegue compreender, qual é o seu sentimento? Goro: Vergonha. PESQUisadora: O que é vergonha? GoRO: Todo mundo ri. PESQUisadora: Isso está acontecendo? Goro: Não. 
Para a criança Goro, o sentimento de vergonha é não compreender a disciplina escolar e o medo de que as outras crianças possam ridicularizá-lo.

\section{Transnacionalismo/descendentes de japoneses}

A migração de ida e volta dos imigrantes sempre existiu, não atingindo, até o momento atual, um volume crítico e a complexidade efetiva para se lançar no campo social emergente. Esses imigrantes são pessoas que vivem em dois lugares, falam dois idiomas e mantêm contados contínuos entre ambos os países (Portes; Guarnizo; Landolt, 1999).

Em sua obra Nuevos retos del transnacionalismo en el estudio de las migraciones, Solé, Parella e Cavalcanti (2008, p.13) assinalam que as antigas migrações são distintas das contemporâneas. As velhas migrações perdem o vínculo com o seu país de origem, ao passo que nas novas migrações o imigrante se mantém vinculado à sua originalidade: "En la actualidad, los inmigrantes desarrollan redes, actividades, estilos de vida e ideologías que engloban a la vez las sociedades de origen y de destino". Portanto, o transnacionalismo é definido como "los procesos a través de los cuales los inmigrantes construyen campos sociales que conectan su país de origen y su país de asentamiento" (Glick Schiller; Bach; Szanton Blanc, 1992 apud Solé; Parella; Cavalcanti, 2008, p.15).

Os descendentes de japoneses podem ser caraterizados como a única migração transnacional secular. Ao migrarem para outro país, não hesitaram em retornar para a terra dos seus antepassados. Os nikkeis brasileiros se mantiveram vinculados ao Japão por meio de cartas dirigidas aos parentes que lá ficaram, que atravessaram oceanos para chegar ao seu destino, numa época em que o transporte marítimo não tinha uma tecnologia rápida e avançada, comparada com nossa tecnologia atual.

De acordo com Solé, Parella e Cavalcanti (2008, p.14), "No todos los migrantes necesariamente se ven imbricados en prácticas 
sociales de carácter transnacional". Isso nos mostra que nem todos os imigrantes são transnacionais; entretanto, o desenvolvimento de novas tecnologias, que é considerado um grande marco nas ciências contemporâneas, tem acelerado os meios de comunicação e de transporte, facilitando e interligando a vida de quem mora do outro lado do mundo.

Os dekasseguis são eminentemente transnacionais, o que não ocorre com brasileiros que emigram para outros países, muitos dos quais acabam perdendo contato com familiares e amigos deixados no Brasil. A grande maioria dos dekasseguis vive um verdadeiro trânsito entre Brasil-Japão, deslocando-se mais de uma vez do Brasil ao Japão e mantendo vínculos afetivos, sociais e econômicos bastante estreitos com amigos e familiares brasileiros. Contudo, a experiência de transnacionalidade para os filhos é bem distinta da dos pais. Primeiro porque os filhos que emigraram bem novos ou que nasceram no Japão não possuem, pelo menos não de maneira forte, referências identitárias brasileiras nem mantêm contatos estreitos com os familiares que residem no Brasil, durante o período da vida que passam no Japão. Também não conseguem manter vínculo algum com aqueles que deixaram no Japão, quando se instalam no Brasil com seus pais retornados.

As crianças filhas de dekasseguis não têm conseguido manter o vínculo com o Japão, o qual se rompeu abruptamente no momento da sua partida. Mesmo com tantos recursos tecnológicos, não conseguem estabelecer uma conexão com a outra parte do mundo, como nos mostra o senhor Ito:

Tem um fato que ela contou para gente e que me marcou. Eu fiquei muito sentido. Ela me falou que os amigos estavam esquecendo. Que todo mundo estava esquecendo dela.

Os pais tentaram fazer contatos com a escola e amigos por meio de cartas, porém nunca obtiveram uma resposta. Nas escolas japonesas é comum os professores serem transferidos para outros lugares e perderem o vínculo com o antigo ambiente. A atitude desses pais 
foi mais um pedido de ajuda, ou seja, um pedido de socorro para suas filhas. De certa forma, eles tentaram resgatar determinado vínculo do passado, sem nenhum êxito.

Mandamos carta para a escola e não voltou. Eu não consigo fazer nada. Como vou fazer algum amigo para ela? Como vou fazer algum contato com professor? [...] Não houve retorno. É complicado também, porque lá no Japão os professores mudam muito. Eles não ficam estabilizados numa escola só. De tempos em tempos eles estão mudando de lugar. É um aperfeiçoamento constante. Eles têm até aulas na faculdade. Então, aquela professora e aquele professor poderiam não estar mais lá. A carta endereçada foi para lá, mas lá não tem o professor. Não tem esse. De repente não conseguiu um outro contato. Ela falou que sonhava. É duro essa questão de sentimento.

Essas crianças filhas de dekasseguis, quando chegam ao Brasil, por não manterem vínculos de amizades com a terra japonesa, temem ser esquecidas pelos seus professores e amigos que ficaram no Japão.

Para essas crianças, quais são os lugares de "origem" e de "destino"?

\section{Identidade híbrida: filhos de dekasseguis, os legítimos nipo-brasileiros}

Será que alguns momentos de refúgio dessas crianças no Brasil estão na identidade brasileira, que nem parece estar clara ou bem definida para elas?

A questão da identidade é um assunto para ser discutido em virtude de sua complexidade, pois estamos estudando crianças descendentes de japoneses e a quarta geração de imigrantes.

Afinal, qual é a identidade dessas crianças filhas de dekasseguis?

Para Hall (2005, p.7), o sujeito contemporâneo é descentralizado, distinto do sujeito da modernidade, que era considerado unificado. 
O sujeito na pós-modernidade é fragmentado, dando origem a novas identidades, num processo que o autor denominou crise de identidade.

A assim chamada "crise de identidade" é vista como parte de um processo mais amplo de mudança, que está deslocando as estruturas e processos centrais das sociedades modernas e abalando os quadros de referência que davam aos indivíduos uma ancoragem estável no mundo social (Hall, 2005, p.7).

No Japão, as irmãs Eiko e Letícia se consideravam japonesas. Para confirmar a naturalidade de Eiko, em seu registro de nascimento constava o nome da cidade japonesa de Matsumoto.

Na verdade existe um problema de choque cultural pelo seguinte. A gente, engraçado, elas consideram japonesas. Olha só que coisa engraçada! Ela no registro de nascimento dela ela nasceu no Japão. Está lá "Matsumoto" [nome da cidade japonesa], tudo direitinho. É uma coisa engraçada assim. Aparência física de nikkei, nikkei, ela se achava assim. Quando ela entrou na escola pública lá e tudo mais, na verdade fala assim: "Por que papai e mamãe não é japonês?".

Ela tinha uma certa vergonha. Um certo preconceito. Não que seja preconceito. O preconceito que nem lhe expliquei agora. Por que ocorre esse preconceito? Devido a isso, ela: "eu sou japonesa". É engraçado ela ouvir dizer que amiguinhos dela "chegou", que eram brasileiros. Fala que é gaijin. Que gaijin o que, minha filha? Você é brasileira. Não é, mamãe. Não é por quê? Tenho aparência de japonês. Quando a gente fala português, ela queria que a gente fosse japonês. Da melhor maneira possivel, ela fala: "Fala que é japonês!"

$\mathrm{Na}$ tentativa de justificar a identidade brasileira de suas filhas, o pai das crianças acaba se contradizendo ao dizer que a avó tem costumes de nikkei-jin, ou seja, a avó seria uma japonesa que está morando fora do Japão, e que a língua japonesa falada em família era normal. 
Isso lá no Japão. Porque lá, ela tinha um certo constrangimento por ser brasileira. Minha filha, você é brasileira. Como os amiguinhos nunca estavam com essa aparência - não só aparência, mas nossos costumes. Tenho uma avó muito rigorosa. Costumes de nikkei-jin, nissei. Para a gente falar o japonês era simples. Fácil.

A questão da identidade não pode ser considerada somente uma discusssão macrossocial, mas também uma discussão microssocial nessas famílias de descendentes de japoneses.

Essa descentralização identitária do sujeito acaba afetando também as crianças filhas de dekasseguis diante das mudanças geográficas e da própria construção da (e)imigração japonesa, que favorecem a experiência de vida entre duas culturas e a criação de novas identidades, uma cultura híbrida.

O problema da identidade da criança Goro era enunciada pela sua aparência de mestiço, por sua mãe ser nikkei brasileira e o pai não ter descendência japonesa.

Tiveram muitas dificuldades, hem. Incluse já pela aparência do meu filho, por ser mestiço. Ele era mestiço. Então, ele se sentia muito complexado por ele não ter olho puxado. Já começou por aí. Ele ficava me perguntando: "Mamãe, por que eu não tenho o olho puxado?". Pra ele, os japoneses eram bonitos e ele era feio. Eu falava para ele: "Nossa, meu filho! Você está pensando diferente, porque os japoneses querem ser ocidentais". Tanto é que lá os homens e as mulheres, eles fazem o possivel para terem os olhos grandes, o cabelo enrolado. Quer parecer com ele. Eu falei para ele: "Quer parecer com você", mas ele não aceitava isso. Até hoje ele fala isso, que bonito é o japonês. Que ele éfeio. Já começou por aí.

No Japão, a nacionalidade brasileira de Goro era algo que justificava a sua diferença entre as demais crianças japonesas e as suas dificuldades de aprendizado na escola japonesa.

Ele sempre vinha falando pra mim: "Mamãe, eu não vou conseguir! Eu não consigo, porque é difícil”. Ele sempre colocava muitos 
empecilhos e ele não conseguia. Aí, ele falava até que "porque eu sou brasileiro".

O conflito identitário vivido por essas crianças é constante em suas vidas. Em um momento se veem japoneses e em outro se veem brasileiros. Na citação abaixo, Goro nega completamente a sua identidade brasileira.

Os coleguinhas dele no primeiro ano até queriam chegar e saber mais dele. Só que ele acabava afastando as crianças. As crianças queriam: "Como que é o Brasil? Como se fala isso em português?". Mas ele não queria, ele detestava falar sobre o Brasil. Porque pra ele, ele não quer ser brasileiro, não aceitou o Brasil. Então, ele falava assim: "Eu não sou brasileiro! Eu sou japonês!”. Ele falava pra mim. Por ele ter sido criado lá e crescido lá, né.

Para Eiko, a confusão identitária também é formada pelo ambiente exterior, onde, apesar de ter passado um século dos primeiros imigrantes japoneses no Brasil, ainda continuam vivendo esse conflito identitário. Portanto, em território japonês o dekassegui descendente de japonês é visto como "brasileiro"; o contrário ocorre quando esse descendente encontra-se em terras brasileiras, pois é visto e chamado de "japonês".

EIKO: Hum, acho que nenhum dos dois, no Japão também as minhas amigas e meus amigos ficavam falando que eu era brasileiro e no Brasil falava que eu era japonês, e não conseguiu do qual sou brasileiro ou japonês.

O sentimento de não pertencimento de Eiko fica claro no relato anterior, em que ela não sabe definir sua própria identidade. Essa indefinição identitária dos descendentes de japoneses brasileiros ainda persiste nessa nova geração que morou no Japão por algum tempo e que chega ou retorna ao Brasil. 
Gosto. Às vezes fico chateada e triste. Porque colega consegue e eu não. Eu também sangue de brasileiro.

Eiko não compreende por que enfrenta tantas dificuldades no ambiente escolar, já que, tendo sangue brasileiro, ela não deveria tê-las.

EIKO: Fui, mas tinha que vir, não tinha jeito. Eu também queria conhecer o Brasil. Porque o Brasil, na minha memória, não consigo lembrar nada. Só vendo a foto que consigo entender que estava aqui.

Hall (2005) explica que o sujeito contemporâneo passa a não ter uma localização social sólida. $\mathrm{O}$ indivíduo perde a sua referência de lugar no mundo social e cultural, e também o referencial de si mesmo.

O hibridismo é definido por Hall (2005) como uma mistura entre distintas tradições culturais e novas formas de construções culturais na modernidade tardia. Essa modernidade tardia é conhecida pelo nome de globalização.

Para Naputano (2012), em sua tese de mestrado Identidades culturais em imigrantes de segunda geração: Os filhos de Pedrinhas, o hibridismo não é a soma de culturas distintas, mas um processo de formações culturais. Para o autor, "a cultura é sempre híbrida no sentido de ter uma perspectiva de construção histórica datada e de tensões político-sociais em sua formação" (Naputano, 2012, p.108).

Se os primeiros imigrantes japoneses que vieram para o Brasil se sentiam japoneses mesmo depois de muito tempo, e se os filhos desses imigrantes se sentiam brasileiros filhos de japoneses, os filhos dos dekasseguis que acompanham seus pais em longas temporadas de trabalho no Japão ou que nasceram no Japão e vieram para o Brasil dificilmente vão deixar de incorporar identificações profundas com ambas as culturas, produzindo uma identidade híbrida: nem brasileiros nem japoneses, mas sim nipo-brasileiros. 


\section{A experiência do desamparo psíquico}

O desamparo psíquico abordado na pesquisa, no processo de adaptação/readaptação dos filhos de dekasseguis na chegada ao Brasil, pode ser identificado nas crianças e também nos próprios pais dekasseguis.

Os pais sentem-se desamparados antes mesmo de retornar para o Brasil. A terra-mãe oriental que, até então, gerava um sentido de amparo ao assegurar o sustento da família, pelo trabalho, e possibilitar outras realizações pessoais, é deixada para trás no retorno para aquela outra terra-mãe nativa de onde antes havia partido.

Para os pais dekasseguis, sobretudo para aqueles evadidos após a crise econômica de 2008, a possibilidade de continuarem morando em terras orientais foi abruptamente interrompida e, com isso, seus sonhos se esvaíram. Em decorrência da falência do Lehman Brothers e de outros conglomerados financeiros e empresas norte-americanas, em 2008, o Japão sofreu uma das suas piores crises econômicas dos últimos tempos, desencadeando um alto índice de desemprego no país. Em razão dessa situação, muitos imigrantes dekasseguis têm retornado para o Brasil. Além disso, os abalos sísmicos continuam se manifestando em todo o território japonês, disparando medo e insegurança nas pessoas que moram no arquipélago, especialmente nos imigrantes brasileiros, pouco acostumados a catástrofes naturais.

O senhor Ito mencionou explicitamente a frustração do seu projeto de permanecer por mais tempo no Japão, até concluir a formação profissional dos seus filhos, quando teve de abreviar sua permanência por causa da crise econômica, que o deixou bastante inseguro. A senhora Haru acrescenta aos motivos econômicos o temor dos terremotos que, mesmo acontecendo em regiões distantes de onde morava, acentuava a sensação de insegurança e a iminência de uma condição de desamparo em terras estrangeiras. O sentimento de desamparo vivido na terra dos avós os faz voltar à terra ocidental brasileira. Assim, teriam o "continente" brasileiro como amparo, ou seja, um porto seguro para suas inseguranças. 
Os pais, ao chegarem ao Brasil, perceberam que o fator idade da criança imigrante é relevante para a adaptação delas ao novo meio. Quando se deslocam bebês ou crianças menores para outros lugares ou países, estes parecem conseguir assimilar mais facilmente a nova vida.

Para os pais, a filha Eiko teve muito mais dificuldades na chegada ao Brasil, em virtude do fator idade, do que a irmã Letícia, que chegou menorzinha. Quando retornou ao Brasil, Eiko tinha quase 10 anos de idade e Letícia, 7 anos. Além da idade, temos que levar em conta o grau de escolaridade dessas crianças quando no ato da migração. Eiko alfabetizou-se na língua japonesa e concluiu no Japão a $3^{\text {a }}$ série, iniciando a $4^{\text {a }}$ série do ensino fundamental, ao passo que Letícia, aos 6 anos e meio, cursou a metade da $1^{\text {a }}$ série escolar no Japão e retornou aos 7 anos de idade para o Brasil. A criança Goro chegou aos 9 anos de idade ao Brasil, tendo cursado no Japão até a $2^{\text {a }}$ série do ensino fundamental. Será que o fator idade pode intensificar ou não o desamparo emocional dessas crianças (e)imigrantes?

Conforme Grinberg e Grinberg (1984), a experiência migratória é vivida de forma distinta em cada fase da vida. Portanto, a criança que migra em idade menor poderá assimilar mais rapidamente o novo entorno.

A criança Letícia chegou ao Brasil com 7 anos de idade e ingressou na metade da $1^{\mathrm{a}}$ série $/ 2^{\circ}$ ano escolar. Apesar de suas dificuldades, Letícia está aprendendo a língua portuguesa com mais facilidade em relação à irmã Eiko e ao primo Goro, e se expressando sem o sotaque japonês. A irmã Eiko, porém, continua tendo dificuldades escolares acentuadas, por ainda não conseguir compreender a língua portuguesa instrumental e abstrata. Assim, ela se sente prejudicada por ter ingressado na $4^{\mathrm{a}}$ série $/ 5^{\circ}$ ano sem nenhum conhecimento da língua portuguesa e em outro país. Demonstra muitos sofrimentos emocionais por ainda não conseguir se adaptar ao Brasil. $\mathrm{O}$ primo Goro, por sua vez, apesar de ter iniciado a $3^{\mathrm{a}}$ série, não cursou a primeira nem a segunda série no Brasil. A senhora Haru interveio para que o filho fizesse os cursos de alfabetização em língua portuguesa e de matemática antes mesmo de ingressar na escola, e também que 
iniciasse a $3^{\mathrm{a}}$ série, e não a $4^{\mathrm{a}}$ série do ensino fundamental, como a escola propunha. Deste modo, a criança Goro não perderia mais um ano escolar no Brasil.

A senhora Haru fez o processo inverso da irmã Natsu, fornecendo ao seu filho Goro alguns recursos para que não ficasse totalmente desamparado na escola. Diante da situação, mesmo dispondo de alguma bagagem na escola, a criança não deixa de se sentir desamparada emocionalmente. O estranhamento e o choque cultural, especialmente ao se deparar com a nova língua instrumental e abstrata, trazem o sentimento de desamparo.

Além da idade, o tempo de permanência das crianças imigrantes em outro ambiente escolar - no caso, na escola japonesa - é relevante para a adaptação na escola brasileira. Elas percebem que estão "atrasadas" no aprendizado, tendo que correr atrás de um "tempo perdido", que não existiu, em terras brasileiras. Portanto, as crianças maiores parecem encontrar mais dificuldades escolares, uma vez que já chegam com uma linguagem cultural mais elaborada do que as crianças menores.

As três crianças entrevistadas chegaram ao Brasil sem saber o idioma português. $\mathrm{O}$ desamparo emocional vivido por elas, reflete o sentimento de perda do conhecimento da única cultura, a perda de sua própria língua, a qual traz conhecimentos abstratos e promove um trânsito entre os dois mundos, do emocional (interno) e da realidade externa. As crianças, ao perderem a língua japonesa, passam a se sentir "estrangeiras dentro do próprio lar". Portanto, o desconhecimento da língua portuguesa é a principal barreira dessas crianças filhas de imigrantes dekasseguis na chegada ao Brasil.

Podemos pensar em dois momentos de grande sofrimento e desamparo psíquico com relação à língua instrumental e cultural na história de vida dessas crianças, logo que chegam ao Brasil:

1) $O$ rompimento abrupto da comunicação na língua japonesa dos pais com as filhas Eiko e Letícia, ao inserirem de forma autoritária a língua portuguesa na vida dessas crianças. 
2) O estranhamento e as dificuldades da língua portuguesa para acompanhar o novo currículo na chegada à escola.

Mesmo que a mãe da criança Goro tenha agido de forma distinta da irmã Natsu, não tendo rompido abruptamente a comunicação japonesa em família, o filho não se livrou da pressão para aprender a língua portuguesa em casa e na escola.

Para Mey (1998, p.76), "a língua se relaciona com a sociedade porque é a expressão das necessidades humanas de se congregar socialmente, de construir e desenvolver o mundo”. Portanto, a língua não é somente um representante singular no sentido pessoal; é, acima de tudo, a expressão social e cultural do indivíduo. A língua dá a interpretação de mundo.

Para Eiko, surgem a preocupação e o medo de esquecer a língua oriental, tendo que estudá-la para que não caia no esquecimento. Esse medo de perder a língua dominante nos leva a pensar que Eiko teme perder suas próprias referências orientais.

Qual a língua nativa dessas crianças? Será que elas têm uma língua "emprestada"? Talvez a língua portuguesa para esses filhos de dekasseguis, logo na sua chegada ao Brasil, tenha sido por certo tempo uma língua que eles não pudessem sentir como sendo sua e que frustrantemente acabavam utilizando de forma "forçada" ou "emprestada" para a comunicação no ambiente familiar e no país. Podemos dizer que, hoje, a língua portuguesa faz parte da experiência cultural desses filhos de dekasseguis, integrando seu novo mundo. Portanto, diante de tanta complexidade, podemos pensar que se trata de crianças bilíngues.

Como menciona Eiko em seu relato, a língua japonesa é considerada uma "ponte" que faz a ligação entre os dois mundos, o japonês e o brasileiro. Entretanto, para a compreensão desse novo mundo é necessário interpretar a mensagem na língua japonesa e traduzi-la para a língua portuguesa. Isso não se resume somente à língua mecânica instrumental - vai muito além disso, uma vez que estamos falando de uma linguagem cultural representada simbolicamente para dar sentido à interpretação da nova vida. Aqui, Eiko enfatiza a 
importância do "bilinguismo"; parece que se trata de uma maneira de conseguir se integrar, não esquecendo a mãe japonesa, mas se unindo à mãe brasileira. Poderíamos pensar, então, que o bilinguismo facilitaria a formação de vínculos de amizades com as crianças da escola e livraria Eiko de viver isolada?

Essas crianças possuem vivências em duas culturas: a japonesa e a brasileira. São crianças consideradas híbridas, pois transitam rapidamente da língua portuguesa para a japonesa. Elas vivem entre dois mundos; estudaram em duas escolas; falam duas línguas; adquiriram costumes e hábitos de dois países; consequentemente carregam consigo uma experiência bicultural, embora a coexistência de referências pessoais a duas culturas não seja algo fácil de ser assimilado e harmonizado na composição da identidade.

O desejo de retornar ao Japão não é sentido somente pelos adultos, mas é manifestado também pelas próprias crianças filhas de dekasseguis. Elas parecem viver um eterno retorno, sempre em busca de um "paraíso perdido". A condição de ser criança e os desastres naturais soam para os filhos como impedimentos para o desejado retorno imediato ao Japão. No entanto, o desejo de reencontrar, um dia, a "mãe oriental" não cessa de se manifestar e ser expresso diretamente. Por isso a importância de manter os vínculos de amizade que foram construídos no Japão e o temor de perdê-los em função das dificuldades de prosseguir relacionamentos e vínculos de amizade, mesmo com tantas tecnologias avançadas de comunicação. Às vezes, nem mesmo as mais novas tecnologias resultam em conexões entre país de origem e país de destino. Portanto, o transnacionalismo não acontece com essas crianças filhas de dekasseguis.

Entretanto, pais e crianças têm que lidar com a possibilidade do "fim" do sonho de retornar ao Japão, mesmo que seja por um determinado tempo. Sonho esse que possui sentidos muito diferentes para pais e filhos, cujas matrizes de identidade cultural podem atingir graus acentuados de inclinação para a cultura japonesa ou para a cultura brasileira. Para os filhos que se sentem japoneses, voltar ao Japão representa reaver a pátria-mãe; para os pais que se sentem brasileiros, ao contrário, significa abandonar a pátria-mãe. Trata-se 
de casos nos quais a identidade familiar não coincide inteiramente com a identidade cultural.

Afinal, qual é a identidade dessas crianças?

Essas crianças filhas de dekasseguis não têm uma identidade homogênea no que diz respeito às referências culturais. São tratadas como "japonesinhos brasileiros" e podem se reconhecer dessa forma ou se opor a tal imagem híbrida.

No Japão, a questão da identidade estava muito presente no cotidiano familiar por causa dos conflitos identitários que, inevitavelmente, assolam os imigrantes e afetam particularmente os dekasseguis, premidos pelas referências de si enquanto brasileiros descendentes de japoneses vivendo no Japão. Essa pluralidade de referências culturais e de filiação, muitas vezes conflitivas, também é vivida por essas crianças que se sentem japonesas, filhos de nipo-brasileiros, vivendo no Brasil ou no Japão.

Definir a sua identidade não é um assunto simples para Eiko, pois ela vive um grande conflito identitário. Não sabe dizer se é brasileira ou japonesa. No Japão, os japoneses falavam que era brasileira, e no Brasil, os brasileiros falam que é japonesa. No entanto, Eiko sente que o Japão é a sua casa. Além do mais, está vivendo paralelamente a fase da adolescência, tornando ainda mais agudas as crises de identidade. A irmã Letícia se declara brasileira por ter nascido em terras brasileiras. Apesar das irmãs, no Japão, se considerarem japonesas, lá já viviam crises identitárias e passam a implorar para que os próprios pais afirmem uma identidade japonesa, não aceitando a identidade brasileira. A identidade do primo Goro, por sua vez, sofre oscilações, vai de acordo a situação do momento; no Japão queria ser japonês e no Brasil diz ser brasileiro.

Qual será o refúgio dessas crianças no Brasil, já que Letícia e Goro não trazem lembranças de um Brasil anterior? Eiko, apesar de ter nascido no Japão, veio para o Brasil bebê e aqui permaneceu por quase 2 anos e meio de vida. Ela tem poucas lembranças de experiências anteriores em terras brasileiras.

Ter o sangue brasileiro, para Eiko, parece remeter a identificações com o país. Talvez a identidade brasileira seja o refúgio para 
essas crianças em alguns momentos de sofrimento emocional e também o desejo de superar as dificuldades na condição de ser criança imigrante no país que deveria ser familiar a ela. Outro momento de refúgio é o sentimento de retorno ao Japão. Pensar em voltar para o Japão é a maneira de evitar sentir-se desamparada em solo brasileiro.

O sentimento de culpa dos pais está ligado à tomada de decisão unilateral de retornar ao Brasil, sem ouvir os filhos, e também ao tratamento educacional rígido que dispensam a eles. Os pais, ao perceberem a radicalidade da mudança e os sofrimentos emocionais que acarretam na família, se culpam por não terem sido capazes de enfrentar os contratempos e temores vividos no Japão e permanecido lá em prol dos filhos. Além de os pais sentirem culpa por tantas experiências dolorosas, as crianças também manifestam sentir culpa por não conseguirem corresponder às expectativas desses pais em relação à dura e difícil realidade, e a culpa também surge por não atingirem as médias nas avaliações escolares, e temem a perda do amor dos pais. Entretanto, essas crianças vivem em suas fantasias experiências de abandono que resultam em desamparo emocional. Esses pais e as crianças imigrantes parecem padecer de um sofrimento duplicado de culpa, ou seja, uma "culpa dobrada".

Os pais, desorientados emocionalmente diante da vivência migratória, acabam não conseguindo servir satisfatoriamente de "capa protetora" para suas filhas.

A senhora Haru, percebendo as dificuldades da criança pelo desconhecimento da língua portuguesa, tenta amenizar a situação, dizendo que no Japão a criança ingressa na escola japonesa e passa a falar em casa a língua japonesa. Argumenta que o filho Goro não lhe deu opção para que pudesse desenvolver a língua portuguesa dentro de casa, ou seja, em família. A mãe se sente vítima da condição de imigrante, afastando o sentimento de culpa. No Brasil, logo na chegada, a senhora Haru tenta fazer a reparação, fornecendo um ambiente mais acolhedor ao seu filho.

Além de tantos sentimentos que surgem nessas famílias dekasseguis, o sentimento de vergonha é outro que eclode dentro desses turbilhões de afetos. 
O sentimento de vergonha dessas crianças imigrantes está explícito em seus comportamentos e relatos. O sentimento de vergonha está ligado ao não saber, ao medo de errar e de se expor diante do outro. Elas trazem em suas fantasias enraizadas a cultura japonesa e a consciência de que não podem falhar. $\mathrm{O}$ sentimento de fracasso gera o sentimento de impotência. Além do mais, essas crianças continuam desvalorizando a terra presente e valorizando a terra ausente. Assim, a terra-mãe oriental continua idealizada e bem viva no mundo interno dessas crianças.

Concluímos que são inúmeras as dificuldades da família dekassegui na chegada ao Brasil, cujo pano de fundo é o estranhamento do ambiente que antes era bastante familiar. Aquelas imagens de si, ligadas a registros de experiências anteriores vividas no Brasil, não coincidem com e não se atualizam naquelas que emergem do presente, gerando um estranhamento de si mesmo. Também é nesse momento que os pais confrontam a identidade cultural de seus filhos, fortemente enraizada na cultura japonesa, o que não era tão evidentemente quando viviam no Japão. A língua será o principal indicador das raízes mais profundas da identidade cultural dos filhos e o desafio maior a ser enfrentado.

O fator idade, o tempo de permanência no exterior e o grau de escolaridade em que essas crianças se encontram no ato da imigração acabam contribuindo para as dificuldades de adaptação/readaptação na escola. Eiko não fez vínculos de amizades e vive isolada, enquanto Letícia e Goro estão se integrando ao novo entorno. Porém, a problemática da língua continua para as três crianças, em níveis distintos de dificuldades. O sentimento de desamparo faz parte da saga familiar desses imigrantes dekasseguis, que passam por separações e muitas perdas nesse trânsito migratório.

Outro aspecto a ser ressaltado nesta pesquisa, à guisa de conclusão, foi a notável importância do espaço criado pelas entrevistas realizadas para que os participantes, sobretudo os filhos dos dekasseguis, pudessem, ali, na relação e no vínculo estabelecido com o pesquisador, expressar, compartilhar e elaborar suas angústias, dificuldades e desafios, rompendo com sentimentos de solidão e 
retraimento que irrompem na experiência do desamparo. Ao longo das sessões de entrevistas foi possível observar uma progressiva desinibição, segurança e confiança na relação, que permitiam àquelas crianças e adolescentes se arriscar a falar, a se comunicar, a expor seus problemas, sentimentos, desejos, projetos, dilemas, enfim, tudo que as afetava nessa rica porém difícil experiência de ter que passar a habitar, repentinamente, um outro mundo, muito diferente daquele ao qual estavam habituadas. A dificuldade maior, tal como pudemos constatar, é não terem espaços e oportunidades, seja na escola, na própria família, seja em outro lugar, justamente para poderem falar e serem escutados em suas agruras e desafios. As sessões de entrevistas que se alongaram por um tempo significativo acabaram por constituir um "espaço continente", onde podiam aportar, com segurança e confiança, para elaborar os acontecimentos de suas derivas e aventuras pelo desconhecido. Assim, esperamos que esse espaço possa ser valorizado e tornar-se um "espaço multiplicado". Alguns desafios se colocam com mais premência e precisam ser enfrentados pelas instituições que lidam diretamente com a realidade dos dekasseguis:

Como as escolas poderiam se preparar para lidar com as dificuldades de adaptação/readaptação, sobretudo no que diz respeito ao aprendizado da língua portuguesa?

Ensinar a língua portuguesa por meio do conhecimento da língua japonesa seria um caminho a ser traçado dentro da instituição escolar? Promoveria, desta forma, o aprendizado do bilinguismo?

Como acolher os dekasseguis retornados, de forma a minimizar seus problemas de adaptação/readaptação na chegada ao Brasil?

Como favorecer o transnacionalismo nas crianças mediante a continuidade de vínculos de amizade com os colegas que deixaram no Japão? Como ajudá-las na formação de laços de amizade com crianças brasileiras? Como promover o transnacionalismo nessas crianças? 



\section{REFERÊNCIAS BIBLIOGRÁFICAS}

ALBORNOZ, S. G. Jogo e trabalho: do homo ludens, de Johann Huizinga, ao ócio criativo, de Domenico De Masi. Cadernos de Psicologia Social do Trabalho, São Paulo, v.12, n.1, jun. 2009. Disponível em: <http://pepsic.bvsalud. org/scielo.php?script=sci_arttext\&pid=S1516-37172009000100007\&lng $=$ pt\&nrm $=$ iso $>$. Acesso em: 9 out. 2013.

AMARAL, T.; CORES, L.; MATSUO, S. História de escolarização no Japão e Brasil de filhos de dekasseguis na década de 1990. In: REUNIÃO ANUAL DA ANPED, 33, 2010, Caxambu. Anais... Caxambu: ANPED, 2010. Disponível em: <http://www.anped.org.br/33encontro/app/ webroot/files/file/ Trabalhos\%20em\%20PDF/GT21-6956--Int.pdf>. Acesso em: 19 ago. 2011.

ASARI, A. Y.; TOMITA, L. M. S. Migrações internacionais para o Japão e a formação escolar dos filhos de dekasseguis. Maringá-Paraná-Brasil. Revista Geografia, Londrina, v.9, n.1, p.54-5, 2000. Disponível em: <http://www. uel.br/revistas/uel/index.php/geografia/article/view/10175/8950>. Acesso em: 18 ago. 2011.

ASSIS, O.; CAMPOS, E. C. De volta para casa: a reconstrução de identidades de emigrantes retornados. Revista Tempo e Argumento [on-line], Florianópolis, v.1, n.2, p.80-99, jul./dez. 2009. Disponível em: <http://www.periodicos.udesc. br/index.php/tempoarticle/view/1834/1437>. Acesso em: 19 ago. 2011.

BÍBLIA SAGRADA. Traduzida das línguas originais com uso crítico de todas as fontes antigas pelos missionários capuchinos. Revisão e atualização das Introduções, Livros principais, Notas e Índices. Lisboa: Nova Edição Papal, 1971-1972. 
BIRMAN, J. Arquivos do mal-estar e da resistência. Rio de Janeiro: Civilização Brasileira, 2006.

BRANT, F.; NASCIMENTO, M. Música: Encontros e despedidas. 1985.

Disponível em: <http://www.paixaoeromance.com/80decada/encontros_despedidas/h\%C2\%ADencontros_e_despedidas.htm >. Acesso em: 13 ago. 2013.

COSTA, J. F. O risco de cada um e outros ensaios de psicanálise e cultura. Rio de Janeiro: Garamond, 2007.

DELIBERADOR, L. M. Y. Estratégia de adaptação dos imigrantes japoneses e problema de readaptação dos filhos de dekasseguis ao Brasil. Universidade Estadual de Londrina. Disponível em: <http://www.tulips.tsukuba.ac.jp/ limedio/dlam/B16/B1624221/5.pdf>. Acesso em: 12 ago. 2011

DICIONÁRIO ENCICLOPÉDICO ILUSTRADO: Veja Larousse. São Paulo: Abril, 2006. v.7.

ENCICLOPÉDIA Delta Universal. Homem Pré-Histórico/Jogos. Rio de Janeiro: Delta, 1980. v.8.

ENNES, M. A. A construção de uma identidade inacabada. Nipo-brasileiros no interior do Estado de São Paulo. São Paulo: Editora Unesp, 2001.

FERREIRA, A. B. H. Mini Aurélio. O dicionário da língua portuguesa. 7.ed. Curitiba: Positivo, 2008.

FERREIRA, R. H.; GARCIA, L. B. R. O lugar e o migrante dekassegui. In: GERARDI, L. H. de O.; MENDES, I. A. Do natural, do social e de suas interações: visões geográficas. Rio Claro: Programa de Pós-Graduação em Geografia - UNESP; Associação de Geografia Teorética -AGETEO, 2002. p.133-42. Disponível em: <http://:www.rc.unesp.br/igcegeografia/ pos/downloads/2002/o-lugar.pdf>. Acesso em: 19 ago. 2011.

FORTES, I. Masoquismo e desamparo no sofrimento contemporâneo. Revista Pulsional de Psicanálise, São Paulo, ano 21, n.4, p.27-38, 2008.

FREUD, S. (1886-1889). Publicações pré-psicanalíticas e esboços inéditos. In: . Obras completas. Rio de Janeiro: Imago, 1996. v.I. p.335-96. (1893-1895). Estudos sobre a histeria. In: Obras completas. Rio de Janeiro: Imago, 1996. v.II. p.13-318.

. (1911-1913). O Caso Schreber, Artigos sobre Técnica e outros trabalhos. In: . Edição Standard Brasileira das obras psicológicas completas. Rio de Janeiro: Imago, 1996. v.XII. p.161-71.

. (1920-1922). Além do princípio de prazer, psicologia de grupo e outros trabalhos. In: Obras completas. Rio de Janeiro: Imago, 1996. v.XVIII. p.13-145. 
. (1925-1926). Um estudo autobiográfico, inibições, sintomas e ansiedade, análise leiga e outros trabalhos. In: Obras completas. Rio de Janeiro: Imago, 1996. v.XX. p.77-170.

(1927-1931). O futuro de uma ilusão e o mal-estar na civilização e outros trabalhos. In: . Obras completas. Rio de Janeiro: Imago, 1996. v.XXI. p.13-73.

(1932-1936). Novas conferências introdutórias sobre psicanálise e outros trabalhos. In: . Obras completas. Rio de Janeiro: Imago, 1996. v.XXII. p.85-112.

FUSCO, W.; SOUCHAUD, S. De volta para casa: a distribuição dos brasileiros retornados do exterior. Revista Confins [on-line], n.9, 2010. Disponível em: $<\mathrm{http} / /$ confins.reveus.org/6469>. Acesso em: 19 ago. 2011.

GALIMBERTTI, P. O caminho que o dekassegui sonhou (Dekassegui no yumê-ji): cultura e subjetividade no movimento dekassegui. São Paulo: Educ, 2002.

GOMES, O. M. C. Violência domésticas e migrações. Curitiba: Juruá, 2012.

GRINBERG, L.; GRINBERG, R. Psicoanálisis de la migración y del exilio. Madri: Alianza, A. A., 1984.

HALL, S. A identidade cultural na pós-modernidade. 10.ed. Rio de Janeiro: DP\&A, 2005.

HASHIMOTO, F. Sol Nascente no Brasil: cultura e mentalidade. Assis: HVF Arte \& Cultura, 1995.

HIGA, M. M. Conflitos intrapsíquicos e interpessoais em um grupo de migrantes brasileiros no Japão. São Paulo, 2006. 354f. Tese (Doutorado em Psicologia) - Instituto de Psicologia, Universidade de São Paulo.

HINATA, N. Dicionário japonês-português romanizado. Japan: Kashiwashobo, 1998.

Japão retoma em Miyagi as buscas por desaparecidos do tsunami. Folha de S.Paulo [on-line], São Paulo, 11 ago. 2012. Mundo. Disponível em: $<$ http://www1.folha.uol.com.br/mundo/1135737-japao-retoma-em-miyagi-as-buscas-por-desaparecidos-do-tsunami.shtml>. Acesso em: 13 set. 2013.

JUSTO, J. S. A chegada dos imigrantes japoneses e a partida dos decasséguis: Dois lados da mesma viagem. In: HASHIMOTO, F.; TANNO, J. L.; OKAMOTO, M. S. (Orgs.). Cem anos da imigração japonesa: história, memória e arte. São Paulo: Editora Unesp, 2008. p.99-123.

KANAAN, B. R. Homo Faber: Uma etnografia de práticas de trabalho na Serra Gaúcha/Rio Grande do Sul. Porto Alegre, 2013. 229f. Tese (Doutorado em Antropologia Social) - Instituto de Filosofia e Ciências Humanas, Universidade Federal do Rio Grande do Sul. Disponível em: < http://www.lume. 
ufrgs.br/bitstream/handle/10183/78172/000896320.pdf?...1>. Acesso em: 9 out. 2013.

KAWAMURA, L. Brasileiros no Japão: direitos e cidadania. In: HASHIMOTO, F.; TANNO, J. L.; OKAMOTO, M. S. (Orgs.). Cem anos da imigração japonesa: história, memória e arte. São Paulo: Editora Unesp, 2008, p.79-98.

KLEIN, M. (1946-1963). Sobre o sentimento de solidão (1963). In:

Inveja e gratidão e outros trabalhos. 4.ed. Rio de Janeiro: Imago, 1991. p.340-53.

. (1946-1963). Notas sobre alguns mecanismos esquizoides (1946). In: . Inveja e gratidão e outros trabalhos. 4.ed. Rio de Janeiro: Imago, 1991. p.17-43.

LAPLANCHE, J.; PONTALIS, J. B. Vocabulário de psicanálise. 2.ed. Santos: Martins Fontes, 1970.

Vocabulário de psicanálise. 4.ed. São Paulo: Martins Fontes, 2001.

Lehman Brothers anuncia que vai declarar concordata. Folha de S.Paulo [on-line], São Paulo, 15 set. 2008. Disponível em: <http://www1.folha.uol. com.br/folha/dinheiro/ult91u444893.shtml>. Acesso em: 13 dez. 2013.

MAFFESOLI, M. Sobre o nomadismo: vagabundagens pós-modernas. Rio de Janeiro: Record, 2001.

MAHER, T. M. Sendo índio em português. In: SIGNORINI, I. (Org.) Lingua(gem) e identidade: elementos para uma discussão no campo aplicado. Campinas: Mercado das Letras; São Paulo: Fapesp, FAEP/Unicamp, 1998. p.115-137.

MARCEL, G. Homo Viator. Turim: Borla, 1967.

MEY, J. L. Etnia, identidade e língua. In: SIGNORINI, I. (Org.). Língua(gem) e identidade: elementos para uma discussão no campo aplicado. Campinas: Mercado das Letras; São Paulo: Fapesp, FAEP/Unicamp, 1998. p. 69-88.

MIURA, I. K. Dekasseguis: Relato de identidade a partir da experiência de trabalho temporário no Japão. In: DEBIAGGI, S. D.; PAIVA, G. J. de (Orgs.). Psicologia, E/Imigração e Cultura. São Paulo: Casa do Psicólogo, 2004. p.191-207. (Col. Psicologia Social - Inconsciente e Cultura.)

NAPUTANO, M. Identidades culturais em imigrantes de segunda geração: os filhos de Pedrinhas. Assis, 2012. Dissertação (Mestrado em Psicologia) Faculdade de Ciências e Letras, Universidade Estadual Paulista.

NICOLELIS, G. L. O segredo da casa amarela. 37.ed. São Paulo: Atual, 1991. OCADA, F. K. Nos subterrâneos do modelo japonês - Os 3Ks: Kitanai (sujo), Kiken (perigoso) e Kitsui (pesado). Araraquara, 2002. 168f. Dissertação 
(Mestrado em Sociologia) - Faculdade de Ciências e Letras, Universidade Estadual Paulista.

OHNO, M. Dicionário básico japonês-português. São Paulo: Aliança Cultural-Japão, 1989.

OSAWA, C. C. Trabalho "porco, perigoso e pesado" dos dekasseguis e incidência de doenças psíquicas. Physis: Revista de Saúde Coletiva, Rio de Janeiro, v.16, n.1, p.129-37, jan./jul. 2006. Disponível em: <http://www.scielo.br/ scielo.php?pid $=$ s0103-73312006000100010\&script $=$ sci_arttext $>$. Acesso em: 26 maio 2013.

PORTES, A.; GUARNIZO, L. E.; LANDOLT, P. The Study of Transnationalism: Pitfalls and Promise of an Emergent. Ethnic and Racial Studies, v.22, n.2, p.217-37, mar. 1999.

QUINODOZ, J. M. A solidão domesticada: a angústia de separação em psicanálise. Porto Alegre: Artes Médicas, 1993.

ROUANET, P. S. A razão nômade: Walter Benjamin e outros viajantes. Rio de Janeiro: Editora da UFRJ, 1993.

SAKANE, S.; HINATA, N. Dicionário português-japonês romanizado. São Paulo: Casa Ono, 1997.

SANTAMARIA, E. La incógnita del extraño: una aproximación a la significación sociológica de la "inmigración no comunitaria". Barcelona: Anthropos, 2002.

SASAKI, E. M. A questão da identidade dos brasileiros migrantes no Japão. In: DEBIAGGI, S. D.; PAIVA, G. J. de (Orgs.). Psicologia, E/Imigração e Cultura. São Paulo: Casa do Psicólogo, 2004. p. 209-26. (Col. Psicologia Social - Inconsciente e Cultura.)

. Movimento dekassegui: a experiência migratória e identitária dos brasileiros descendentes de japoneses no Japão. In: REIS, R. R.; SALES, T. Cenas do Brasil migrante. São Paulo: Boitempo, 1999. p. 243-74.

SCHILLER, G. N. Nuevas y viejas cuestiones sobre localidad: teorizar la migración trasnacional en un mundo neoliberal. In: SOLÉ, C.; PARELLA, S.; CAVALCANTI, L. (Orgs.). Nuevos retos del transnacionalismo en el estudio de las migraciones. Barcelona: Grafo, 2008. p. 7-217.

SEGAL, H. A posição esquizo-paranoide. In: SEGAL, H. Introdução à obra de Melanie Klein. Rio de Janeiro: Imago, 1975. p. 36-50. (Col. Psicologia Psicanalítica.)

SOLÉ, C.; PARELLA, S.; CAVALCANTI, L. (Orgs.). Nuevos retos del transnacionalismo en el estudio de las migraciones. Barcelona: Grafo, 2008.

Usina nuclear de Fukushima tem novo vazamento de água contaminada. Folha de S.Paulo [on-line], São Paulo, 5 jun. 2013. Mundo. Disponível em: 
<http://www1.folha.uol.com.br/mundo/2013/06/1290023-usina-nuclear-de-fukushima-tem-novo-vazamento-de-agua-contaminada.shtml $>$. Acesso em: 13 set. 2013.

WAKISAKA, K. (Org). Michaelis: dicionário prático japonês-português. São Paulo: Aliança Cultural Brasil-Japão, 2003.

WINNICOTT, D. W. (1896-1971). A família e o desenvolvimento individual. 3.ed. São Paulo: Martins Fontes, 2005. (Psicologia e Pedagogia.) . O brincar $\&$ a realidade. Rio de Janeiro: Imago, 1975. (Col. Psicologia Psicanalítica.) 


\section{GLosSÁRIO}

Daijoobu: [adj-v] seguro, certo (Ohno, 1989, p.83).

Dame: [adj-v] inútil, ruim; sem esperança; impossível; dever, não poder (Ohno, 1989, p.87).

Dekassegui: originado do japonês deru (sair) e kasegu (ganhar dinheiro). Aquele(a) que sai para trabalhar fora em serviços temporários para ganhar dinheiro. Anteriormente o termo dekassegui era usado para os japoneses das ilhas do norte e nordeste que se deslocavam temporariamente para as regiões do sul do Japão em busca de trabalho, para fugir dos invernos rigorosos da região. Entretanto, o termo dekassegui também é usado para os descendentes de japoneses que se deslocam para o Japão em busca de trabalhos temporários.

Depaato: loja de departamentos, magazine (Hinata, 1998, p.60).

Hidoi: [adj] forte, intenso, violento, extremo, cruel, terrível, atroz (Ohno, 1989, p.191).

Hiragana: forma de escrita japonesa usada para palavras de origem japonesa.

Hottikisu: grampeador (apropriação de hotkeys).

Kanji: forma de caracteres da escrita japonesa.

Katakana: forma de escrita japonesa usada para palavras de origem estrangeira.

Kibishii: [adj] severo, rigoroso; intenso (Ohno, 1989, p.349).

Kiken: [s, adj-v] perigo, risco, perigoso (Ohno, 1989, p.355).

Kirai: [adj-v] desgosto, antipatia, aversão, ódio (Ohno, 1989, p.360).

Kirigami: prática artística, como origami, que utiliza como matéria-prima papel cortado. 
Kitanai: [adj] sujo (Ohno, 1989, p.368).

Kitsui: apertado(a), duro(a), pesado(a), áspero(a), severo(a) (Hinata, 1998, p.219).

Kokugo: [s] língua japonesa; língua pátria (Ohno, 1989, p.383).

Kumon: escola de idiomas (japonês, português, inglês) e de matemática.

Mangás: história em quadrinhos, desenho animado, tira cômica, cartum (Hinata, 1998, p.263).

Nikkei: [Nikkei no] de origem japonesa.

Nikkei-jin: pessoa de origem japonesa (Hinata, 1998, p.315).

Romaji: o alfabeto romano.

Sansei: cidadão (cidadã) brasileiro(a) neto(a) de emigrante (imigrante) japonês; terceiro(a) (Hinata, 1998, p.373).

Tanoshii: [adj] agradável, feliz, apreciável, alegre, contente (Ohno, 1989, p.759).

Teiji: horário ou período estabelecido (Hinata, 1998, p.465).

Tsunami: maremoto.

Urashima Taro: conto infantil japonês.

Ureshii: [adj] estar feliz, contente, satisfeito, alegre (Ohno, 1989, p.855).

Uwa-baki: sapatilha que se usa dentro das escolas japonesas. 
SOBRE O LIVRO

Formato: $14 \times 21 \mathrm{~cm}$

Mancha: $23 \times 40$ paicas

Tipologia: Horley Old Style 10,5/14

1a edição: 2015

EQUIPE DE REALIZAÇÃO

Capa

Megaarte Design

Edição de texto

Tomoe Moroizumi (Copidesque)

Fábio Bonillo (Revisão)

Editoração eletrônica

Sergio Gzeschnik (Diagramação)

Assistência editorial

Jennifer Rangel de França 


